\begin{tabular}{|c|c|}
\hline UnB & $\begin{array}{c}\text { UFPB } \\
\text { Universidade de Brasília }\end{array}$ \\
$\begin{array}{c}\text { Universidade Federal da } \\
\text { Paraíba }\end{array}$ & $\begin{array}{c}\text { UFRN } \\
\text { Universidade Federal do } \\
\text { Rio Grande do Norte }\end{array}$ \\
\hline Programa Multiinstitucional e Inter-Regional de Pós-graduação em Ciências Contábeis \\
\hline
\end{tabular}

JOSIMAR PIRES DA SILVA

ANÁLISE DA PERCEPÇÃO DOS USUÁRIOS DA INFORMAÇÃO CONTÁBIL SOBRE A PROPOSTA DE REVISÃO DA ESTRUTURA CONCEITUAL DO IASB

BRASÍLIA 
UNIVERSIDADE DE BRASÍLIA - UnB

\author{
Reitor: \\ Professor Doutor Ivan Marques de Toledo Camargo \\ Vice-Reitora: \\ Professora Doutora Sônia Nair Baó \\ Decano de Pesquisa e Pós-Graduação: \\ Professor Doutor Jaime Martins de Santana
}

Diretor da Faculdade de Economia, Administração e Contabilidade

Professor Doutor Roberto de Goes Ellery Junior

Chefe do Departamento de Ciências Contábeis e Atuariais:

Professor Doutor José Antônio de França

Coordenador Geral do Programa Multiinstitucional e Inter-regional de Pós Graduação em Ciências Contábeis da UnB, UFPB e UFRN

Professor Doutor Rodrigo de Souza Gonçalves 


\section{ANÁLISE DA PERCEPÇÃO DOS USUÁRIOS DA INFORMAÇÃO CONTÁBIL SOBRE A PROPOSTA DE REVISÃO DA ESTRUTURA CONCEITUAL DO IASB}

Dissertação apresentada como requisito parcial à obtenção do título de Mestre em Ciências Contábeis do Programa Multiinstitucional e Inter-Regional de Pós-Graduação em Ciências Contábeis da Universidade de Brasília, da Universidade Federal da Paraíba e da Universidade Federal do Rio Grande do Norte.

Orientador: Dr. Jorge Katsumi Niyama Área de Concentração: Mensuração Contábil

Linha de pesquisa: Contabilidade e Mercado Financeiro.

Grupo de Pesquisa: Normatização Contábil

\section{BRASÍLIA}


Silva, Josimar Pires da

Análise da Percepção dos Usuários da Informação Contábil Sobre a Proposta de Revisão da Estrutura Conceitual do IASB / Josimar Pires da Silva - Brasília, DF, 2014.

$179 \mathrm{f}$.

Orientador: Prof. Dr. Jorge Katsumi Niyama

Dissertação (mestrado) - Universidade de Brasília. Faculdade de Economia, Administração e Ciências Contábeis e Atuariais - FACE. Programa Multiinstitucional e Inter-Regional de PósGraduação em Ciências Contábeis (UnB/UFPB/UFRN).

1. Estrutura Conceitual da Contabilidade. 2. DP/2013/1. 3. IFRS 4. Usuários da Informação Contábil. 5. Análise de Conteúdo I. NIYAMA, Jorge Katsumi. II. Universidade de Brasília. III. Universidade Federal da Paraíba. IV. Universidade Federal do Rio Grande do Norte. 


\section{ANÁLISE DA PERCEPÇÃO DOS USUÁRIOS DA INFORMAÇÃO CONTÁBIL SOBRE A PROPOSTA DE REVISÃO DA ESTRUTURA CONCEITUAL DO IASB}

Dissertação apresentada como requisito parcial à obtenção do título de Mestre em Ciências Contábeis do Programa Multiinstitucional e Inter-Regional de Pós-Graduação em Ciências Contábeis da Universidade de Brasília, da Universidade Federal da Paraíba e da Universidade Federal do Rio Grande do Norte.

Comissão Avaliadora:

Prof. Dr. Jorge Katsumi Niyama

Programa Multiinstitucional e Inter-regional de Pós-Graduação em Ciências Contábeis da UnB/UFPB/UFRN

(Presidente da Banca)

Prof. Dr. José Alves Dantas

Programa Multiinstitucional e Inter-regional de Pós-Graduação em Ciências Contábeis da UnB/UFPB/UFRN

(Membro Examinador Interno)

Prof ${ }^{\mathrm{a}}$. Dra. Ana Maria Rodrigues

(Membro Examinador Externo)

Brasília, 17 de dezembro de 2014. 
Dedico esse Mestrado a minha mãe Damiana Carolina - por ter me ensinado o caminho que deveria seguir e acima de tudo ter me feito trilhar por ele. Cristo não fazia o que as pessoas queriam, mas o que elas necessitavam: Os melhores pais não são aqueles que fazem o que os filhos querem, mas sim, o que eles necessitam. 


\section{AGRADECIMENTOS}

Em primeiro lugar, agradeço ao Supremo Criador de todas as coisa - DEUS - pela oportunidade (força, graça, segurança, saúde, coragem, compreensão, ousadia e dedicação) de cursar o Mestrado. Sem ele nenhuma parte dessa trajetória teria sido percorrida.

Agradeço aos meus país, Sebastião Pires e Damiana Carolina, pela força, incentivo e principalmente pela educação que me foi transmitida no transcorrer dos anos. Em especial a Sra. Damiana Carolina, que não mediu esforços para que eu não desistisse da escola primaria - És a razão da minha existência.

A minha esposa - Daiana Cardoso - pelo carinho, amor, afeto, dedicação, paciência, compreensão no decorrer dos anos, principalmente nesses dois anos de dedicação ao mestrado. Distância, viagens, dificuldades e obstáculos, tudo foi superado.

A toda minha família, em especial, minha irmã, Cleide, que - mesmo distante - me deu forças, palavra de consolo, de animo, de coragem.

Aos meus colegas de classe: David, Lissandra, Tatiane Sá, Tiago, Vinicius e Vitória. Mesmo diante de nossas indiferenças, esse grupo nos momentos certos se uniu e a individualidade de cada um foi somada, de forma que nos ajudamos, e juntos conseguimos chegar ao final dessa empolgante jornada. Agradeço pelas palavras de incentivo que trocamos no decorrer desses quase dois anos. Agradeço pelas experiências compartilhadas. Agradeço amizade alcançada.

Agradeço ao meu ilustre orientador, Prof. Dr Jorge Katsumi Niyama, primeiramente por me escolher como orientando, pela confiança, dedicação, paciência, amizade, apoio e contribuições neste trabalho e além do mais, por me direcionar na realização de uma pesquisa tão amável. Conduziu-me com extrema perfeição, cobrando quando necessário e principalmente incentivando em todas as nossas reuniões. Obrigado por fazer parte desse "Sonho".

Aos meus professores do Mestrado: Dr Jorge Katsumi Niyama, Dr César Augusto Tibúrcio Silva, Dr. Rodrigo de Souza Gonçalves, Dr. Paulo Roberto Barbosa Lustosa, Dr. Bruno Vinícius Ramos Fernandes, Dra Fernanda Fernandes Rodrigues, Dr. Otávio Ribeiro de Medeiros, Dra. Fátima de Souza Freire e Dra Mariana Guerra, pelo conhecimento compartilhado.

Agradeço ao Prof. Dr. Rodrigo de Souza Gonçalves, Coordenador Geral do Programa Multiinstitucional e Inter-Regional e Pós-Graduação em Ciências Contábeis da UnB/UFPB/UFRN, pelo apoio, incentivo, confiança e pela oportunidade de realizar esse sonho.

À Coordenação de Aperfeiçoamento de Pessoal de Nível Superior (CAPES), pelo apoio financeiro durante o mestrado. 
Agradeço aos membros da Banca Examinadora, Prof. Dr. Jorge Katsumi Niyama (orientador), Professora Dra. Ana Maria Rodrigues (Membro externo) e Prof. Dr. José Alves Dantas (Membro interno), pelas diversas contribuições na realização dessa pesquisa.

Agradeço aos avaliadores do Projeto inicial, Prof. Dr. José Alves Dantas e Prof. Edilson Paulo, pelas diversas contribuições.

Agradeço ao meu primeiro professor de Ciências Contábeis, Prof. Oduvaldo Olivieri, pela arte de ensinar e por me fazer apaixonar pela contabilidade.

Agradeço ao meu orientador na graduação, Prof. André Mesquita, pelo companheirismo e principalmente por me incentivar a realização do mestrado em uma excelente universidade.

Aos funcionários da secretaria geral do Programa, Rodolfo, Sara e Inêz, pelas orientações, auxílios e bons atendimentos prestados, quando solicitados e quando necessários.

Agradeço aos meus amigos e colegas, que caminharam junto no decorrer desses anos, dandome força nessa oportuna jornada.

Por fim, a todos que contribuíram de forma direta ou indireta e que sempre torceram por mim, meus sinceros agradecimentos. 
É muito melhor arriscar coisas grandiosas, alcançar triunfos e glórias, mesmo expondo-se a derrota, do que formar fila com os pobres de espírito que nem gozam muito nem sofrem muito, porque vivem nessa penumbra cinzenta que não conhece vitória nem derrota.

Theodore Roosevelt 


\section{RESUMO}

Como resultado da busca por um arcabouço teórico que desse suporte as políticas e práticas contábeis em nível internacional, em 1989, foi emitida, pelo IASC, a primeira Estrutura Conceitual da Contabilidade. Ela foi resultado das contribuições do FASB, através do Referencial Conceitual e dos esforços do IASC/IASB na busca pela harmonização e convergência. Em 2010 foram emitidos dois capítulos da Estrutura Conceitual revisada esforços conjuntos do FASB e IASB na busca pela convergência - os quais evidenciavam: $\mathrm{O}$ Objetivo de Relatórios Contábeis de Uso Geral; e Características Qualitativas das Informações Financeiras Úteis. Em 2012 o IASB reiniciou os trabalhos, porém sem a participação do FASB e emitiu e disponibilizou ao público em 2013 o Discussion Paper DP/2013/1 - A Review of the Conceptual Framework for Financial Reporting - para que os usuários da informação contábil pudessem remeter opiniões acerca da proposta, para à qual foram recepcionadas comment letters, até 14 de janeiro de 2014 e disponibilizadas para acesso público, no sitio eletrônico do IASB. Assim, esta pesquisa pretende analisar a percepção dos usuários da informação contábil acerca da proposta de revisão da Estrutura Conceitual da contabilidade e descobrir qual o nível de concordância ou discordância dos usuários perante a proposta do DP/2013/1 e quais as taxonomias dos argumentos utilizados para fundamentar a opinião dos respondentes, à luz da teoria contábil. Esta pesquisa teve como objetivo geral analisar a percepção dos usuários da contabilidade sobre a proposta de revisão da Conceptual Framework for Financial Reporting propostos no Discussion Paper - DP/2013/1 emitido pelo International Accounting Standard Board - IASB. Foram coletadas 227 comment letters, contendo as opiniões dos respondentes no tocante às perguntas propostas no DP/2013/1 e foram selecionadas aquelas que respondiam todas as perguntas, perfazendo um total de 80 cartas. Das 26 (vinte e seis) perguntas totais, 22 foram selecionadas - aquelas que se enquadravam no perfil da pesquisa - para futuro detalhamento, totalizando 44 perguntas. Com base na técnica análise de conteúdo foi construído banco de dados, com a análise de cada carta. Foram obtidas as respostas para cada pergunta em duas vertentes: a) se o respondente concordava, discordava ou concordava parcialmente com o assunto proposto para a questão em análise e b) se o respondente embasava sua resposta e que tipo de argumento utilizava. Os resultados gerais evidenciaram um total de 3.520 respostas. O nível de concordância perfaz um percentual de 69,72, seguido por 20,91 e 9,38 pontos percentuais, respectivamente para o nível de discordância e opiniões parciais. Em linhas gerais, $47 \%$ dos argumentos pertencem à categoria escopo, seguido pela respostas Sem Argumento com 21\%, Exemplos com 9\%, Efeitos Internos e Externos com 7\%, Due process com 6\% e Definição com 2\%. Assim, os resultados da pesquisa evidenciaram que a maioria dos respondentes concorda com a proposta do IASB e, para embasar seus argumentos - no geral - fazem uso da experiência prática e o que pensam no tocante a determinados assuntos, sem a utilização de qualquer embasamento teórico que desse suporte a temática analisada.

Palavras-chave: Estrutura Conceitual da Contabilidade. DP/2013/1. IFRS. Usuários da Informação Contábil. Análise de Conteúdo. 


\begin{abstract}
As a result of the search for a theoretical framework that supported the accounting policies and practices at the international level, in 1989, was issued by the IASC, the first Conceptual Framework for Financial Reporting. It was the result of contributions from the FASB, through Conceptual Referential and efforts of the IASC/IASB in the quest for harmonization and convergence. In 2010 were issued two chapters of the revised Conceptual Frameworkjoint efforts of the FASB and IASB in the quest for convergence - which evidenced: The Objective of General Purpose Financial Reporting; and Qualitative Characteristics of Useful Financial Information. In 2012, the IASB resumed work, but without the participation of the FASB and issued and made available to the public in 2013, the Discussion Paper - DP / 2013/1 - A Review of the Conceptual Framework for Financial Reporting - for users of accounting information could submit views on the proposal to which the comment letters were received until January 14, 2014 and made available for public access in the electronic site of the IASB. Thus, this research aims to analyze the perception of the users of accounting information on the proposed revision of the Conceptual Framework of Financial Reporting and discover which level of agreement or disagreement of users before the proposal of DP/2013/1 and that the taxonomies of the arguments used to support the opinion of respondents, in light of the accounting theory. This research aimed to examine the perceptions of users of accounting on the proposed revision of the Conceptual Framework for Financial Reporting proposed in the Discussion Paper - DP/2013/1 issued by the International Accounting Standards Board - IASB. Were collected 227 comment letters, containing the opinions of respondents regarding the questions proposed in the DP/2013/1 and were selected those who answered all questions, totalizing of 80 letters. Of 26 (twenty six) total questions, 22 were selected - those who fit the profile of research - for further details, totaling 44 questions. Based on the content analysis technique was built database with the analysis of each letter. Responses were obtained for each question in two ways: a) if the respondent agreed, disagreed or partially agreed with the subject proposed for the question under consideration and b) if the respondent grounded their response and what kind of argument used. The overall results showed a total of 3,520 responses. The level of agreement amounts to a percentage of 69.72 , followed by 20.91 and 9.38 percentage points respectively for the level of disagreement and partial views. In general, $47 \%$ of arguments are class scope, followed by the answers No Argument with $21 \%$, with $9 \%$ Examples, Internal and External Effects with 7\%, Due Process with 6\% and Definitions with 2\%. Thus, the survey results showed that most respondents agree with the proposal of the IASB and to support their arguments - in general - make use of practical experience and what they think regarding certain issues without the use of any theoretical foundation that supported within the analysis.
\end{abstract}

Key words: Conceptual Framework for Financial Reporting. DP/2013/1. IFRS. Users of Accounting Information. Content Analysis. 


\section{LISTA DE FIGURAS}

Figura 1 - Quantidade de Respostas por Sistema Contábil ..........................................................................

Figura 2 - Nível de Concordância por Setor de Atuação...................................................................... 75

Figura 3 - Nível de Concordância/Discordância das Perguntas Introdutórias...................................... 76

Figura 4 - Nível de Concordância/Discordância das Perguntas sobre Elementos dos Relatórios Financeiros

Figura 5 - Nível de Concordância/Discordância das Perguntas sobre Orientação de Apoio as

Definições de Ativo e Passivo

Figura 6 - Opinião dos respondentes em relação às visões acerca da definição de Obrigação Presente.

Figura 7 - Nível de Concordância/Discordância das Perguntas sobre Reconhecimento e Desreconhecimento

Figura 8 - Nível de Concordância/Discordância das Perguntas sobre Definição de PL e Distinção de Passivo e Instrumento de Capital 86

Figura 9 - Nível de Concordância/Discordância das Perguntas sobre Mensuração 90

Figura 10 - Nível de Concordância/Discordância das Perguntas sobre Apresentação e Divulgação 95 Figura 11 - Nível de Concordância/Discordância das Perguntas sobre Apresentação na DRA Lucros e Perdas e Outros Resultados Abrangentes 97

Figura 12 - Preferencia dos Respondentes em relação às abordagens OCI........................................98

Figura 13 - Nível de Concordância/Discordância das Perguntas sobre Outros Questões ..............101

Figura 14 - Taxonomia Geral dos Argumentos Utilizados .................................................................. 105

Figura 15 - Relação entre a Opinião Geral e a Taxonomia dos Argumentos ..................................... 106

Figura 16 - Relação entre a Taxonomia dos Argumentos e Setores de Atuação ................................ 108

Figura 17 - Taxonomia dos Argumentos Utilizados - Introdução......................................................110

Figura 18 - Relação da Opinião Geral com a Taxonomia do Argumento - Introdução ..................111

Figura 19 - Relação da Opinião Geral com a Taxonomia do Argumento - Introdução .................113

Figura 20 - Taxonomia dos Argumentos Utilizados - Elementos de Relatórios Financeiros ......114 Figura 21 - Relação da Opinião Geral com a Taxonomia do Argumento - Elementos de Relatórios Financeiros

Figura 22 - Taxonomia dos Argumentos por Pergunta - Elementos de Relatórios Financeiros...116 Figura 23 - Taxonomia dos Argumentos Utilizados - Orientação Adicional de Apoio as Definições de Ativo e Passivo. 
Figura 24 - Relação da Opinião Geral com a Taxonomia do Argumento - Orientação Adicional de Apoio as Definições de Ativo e Passivo.

Figura 25 - Taxonomia dos Argumentos por Pergunta - Orientação Adicional de Apoio as Definições de Ativo e Passivo

Figura 26 - Taxonomia dos Argumentos Utilizados - Reconhecimento e Desreconhecimento ..120 Figura 27 - Relação da Opinião Geral com a Taxonomia do Argumento - Reconhecimento e Desreconhecimento

Figura 28 - Taxonomia dos Argumentos por Pergunta - Reconhecimento e Desreconhecimento.122 Figura 29 - Taxonomia dos Argumentos Utilizados - Definição de PL e Distinção de Passivo e Instrumento de Capital 123

Figura 30 - Relação da Opinião Geral com a Taxonomia do Argumento - Definição de PL e Distinção de Passivo e Instrumento de Capital 124

Figura 31 - Taxonomia dos Argumentos por Pergunta - Definição de PL e Distinção de Passivo e Instrumento de Capital 125

Figura 32 - Taxonomia dos Argumentos Utilizados - Mensuração 126

Figura 33 - Relação da Opinião Geral com a Taxonomia do Argumento - Mensuração. 127

Figura 34 - Taxonomia dos Argumentos por Pergunta - Mensuração. 128

Figura 35 - Taxonomia dos Argumentos Utilizados - Apresentação e Divulgação. 129

Figura 36 - Relação da Opinião Geral com a Taxonomia do Argumento - Apresentação e Divulgação 130

Figura 37 - Taxonomia dos Argumentos por Pergunta - Apresentação e Divulgação 132

Figura 38 - Taxonomia dos Argumentos Utilizados - Apresentação na Demonstração do Resultado Abrangente - Lucros ou Perdas e Outros Resultados Abrangentes 133

Figura 39 - Relação da Opinião Geral com a Taxonomia do Argumento - Apresentação na Demonstração do Resultado Abrangente - Lucros ou Perdas e Outros Resultados Abrangentes 134 Figura 40 - Taxonomia dos Argumentos por Pergunta - Apresentação na Demonstração do Resultado Abrangente - Lucros ou Perdas e Outros Resultados Abrangentes 135

Figura 41 - Taxonomia dos Argumentos Utilizados - Outras Questões 136

Figura 42 - Relação da Opinião Geral com a Taxonomia do Argumento - Outras Questões 137 Figura 43 - Taxonomia dos Argumentos por Pergunta - Outras Questões 138 


\section{LISTA DE TABELAS}

Tabela 1 - Quantidade de Respostas por Continente de Origem ...........................................................68

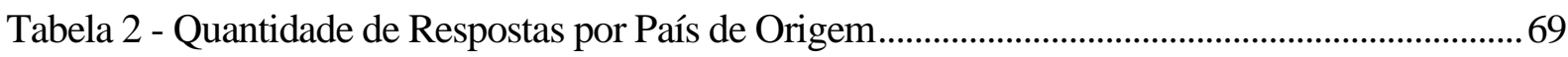

Tabela 3 - Quantidade de Resposta por Setor de Atuação ......................................................................72

Tabela 4 - Nível de Concordância/Discordância por Pergunta e Geral ................................................... 74

Tabela 5 - Índice de Concordância/Discordância - Introdução................................................................... 77

Tabela 6 - Índice de Concordância/Discordância - Elementos dos Relatórios Financeiros................ 80

Tabela 7 - Índice de Concordância/Discordância - Orientação Adicional de Apoio as Definições de

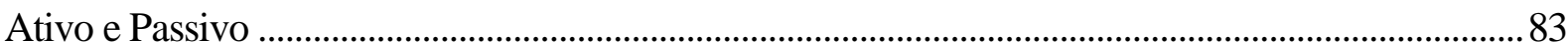

Tabela 8 - Índice de Concordância/Discordância - Reconhecimento e Desreconhecimento ............. 85

Tabela 9 - Índice de Concordância/Discordância - Definição de PL e Distinção de Passivo e

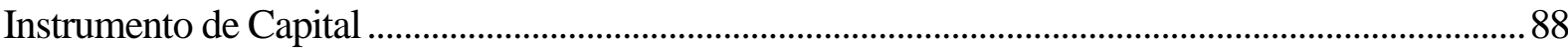

Tabela 10 - Índice de Concordância/Discordância - Mensuração .............................................................93

Tabela 11 - Índice de Concordância/Discordância - Apresentação e Divulgação ................................95

Tabela 12 - Índice de Concordância/Discordância - Apresentação na DRA - Lucros e Perdas e

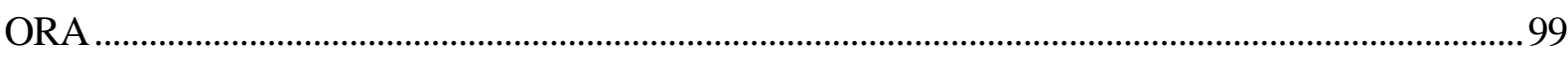

Tabela 13 - Índice de Concordância/Discordância - Outras Questões ................................................101

Tabela 14 - Taxonomia dos Argumentos pelo Grupo de Análise ......................................................... 107

Tabela 15 - Relação entre a Taxonomia dos Argumentos e o Setor de Atuação 109 


\section{LISTA DE QUADROS}

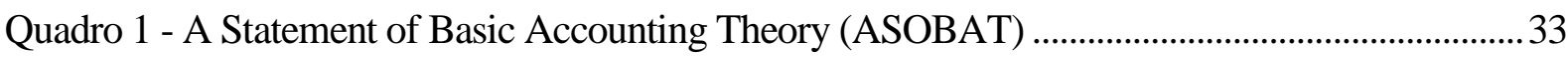

Quadro 2 - Basic Concepts and Accounting Principles Underlying Financial Statements of Business

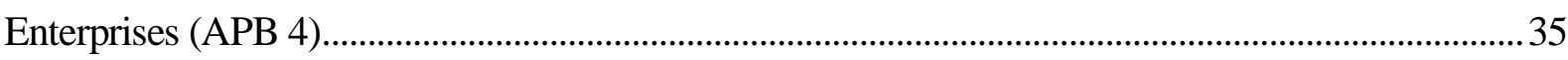

Quadro 3 - Classificação da taxonomia dos argumentos utilizados ......................................................... 66 


\section{LISTA DE ABREVIATURAS E SIGLAS}

AAA American Accounting Association

AAPA American Association of Public Accountants

AIA American Institute of Accountants

AICPA American Institute of Certified Public Accountants

AISG Accountants International Study Group

APB Accounting Principles Board

ARB Accounting Research Bulletins

ARS Accounting Research Studies

ASBE Accounting Standards for Business Enterprises

ASOBAT A Statement of Basic Accounting Theory

ARS Accounting Terminology Bulletins

ATB Accounting Terminology Bulletins

CAP Committee on Accounting Procedure

CEE Comunidade Econômica Européia

CF Conceptual Framework

CFC Conselho Federal de Contabilidade

CICA Canadian Institute of Chartered Accountants

CVM Comissao de Valores Mobiliários

DP Discussion Paper

EEC European Economic Community

EU European Union

FAF Financial Accounting Fundation

FTC Federal Trade Commission

GAAP Generally Accepted Accounting Principles

IAS International Accounting Standards

IASB Internacional Accounting Standards Board

IASC Internacional Accounting Standards Committee

IASCF International Accounting Standard Committee Foundation

ICAEW Institute of Chartered Accountants in England and Wales

ICAS Institute of Chartered Accountants

ICC Interstate Commerce Commission 
IBRACON Instituto de Auditores Independentes do Brasil

IOSCO International Organization of Securities Commissions

JWG Financial Instruments Joint Working Group of standard setters

NYSE New York Stock Exchange

SFAC Statements of Financial Accounting Concepts

UE União Europeia

US GAAP United States Generally Accepted Accounting Principles 


\section{SUMÁRIO}

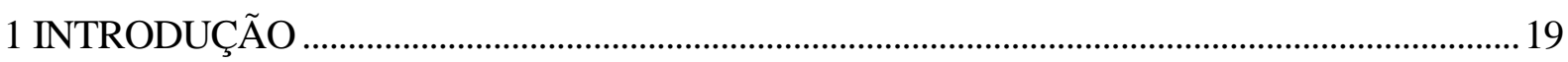

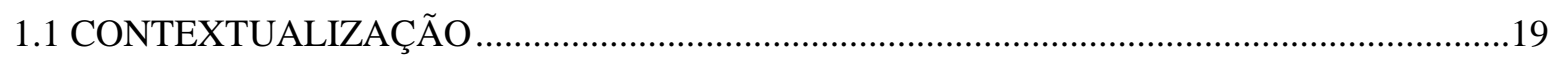

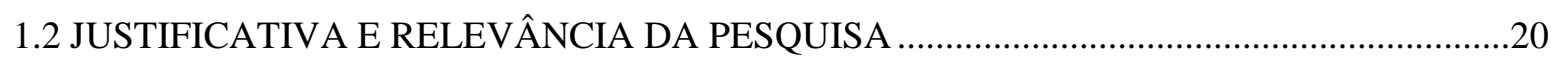

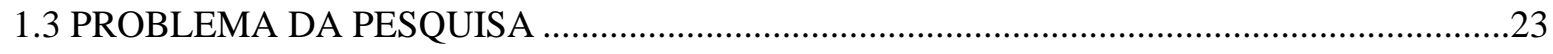

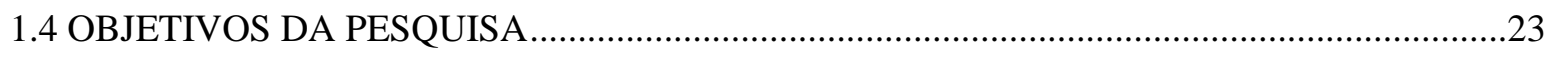

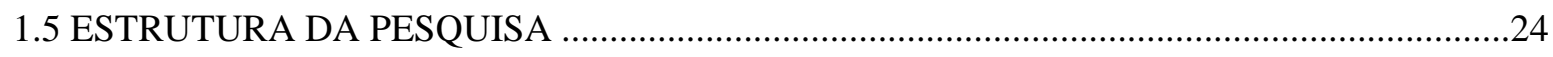

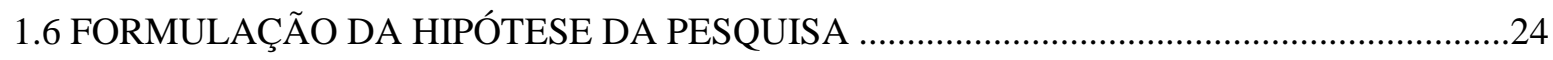

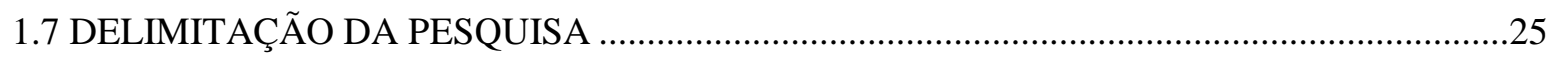

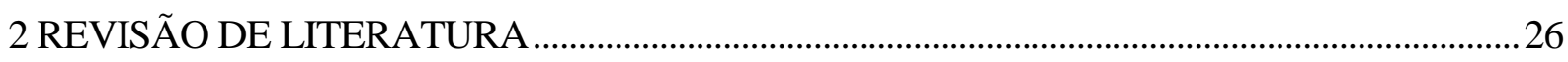

2.1 EVOLUÇÃO HISTÓRICA DA ESTRUTURA CONCEITUAL DOS EUA...............................26

2.1.1 American Accounting Association e American Institute of Certified Public Accoutants ..... 27

2.1.2 Primeiras Contribuições para a Estrutura Conceitual.......................................................... 27

2.1.3 A Era do Committee on Accounting Procedure (CAP) ....................................................... 29

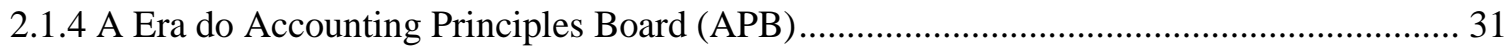

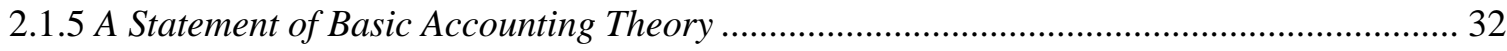

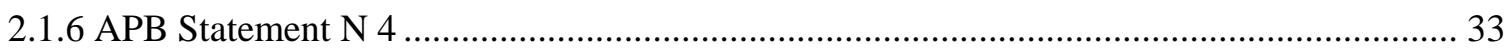

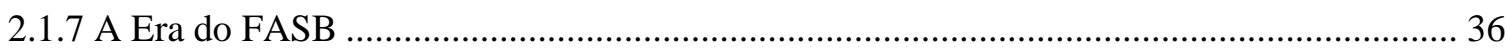

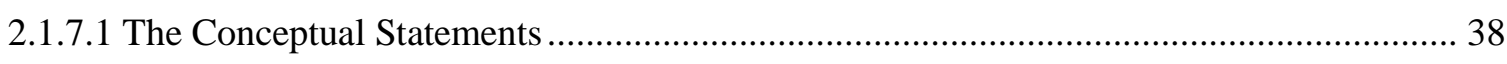

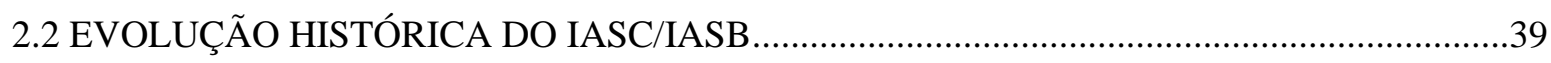

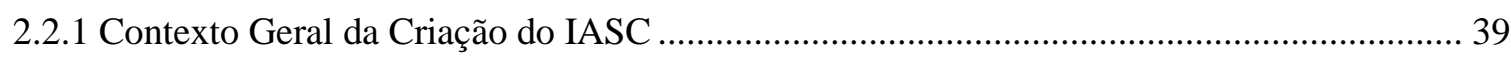

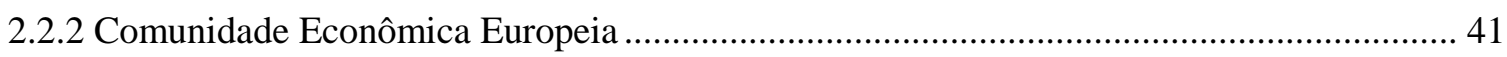

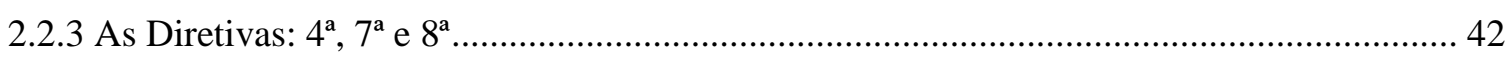

2.2.4 Criação do International Accounting Standards Board - IASB ............................................ 43

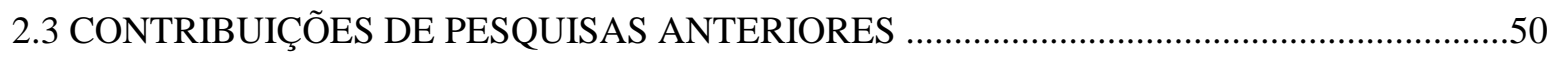

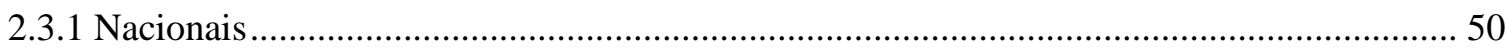

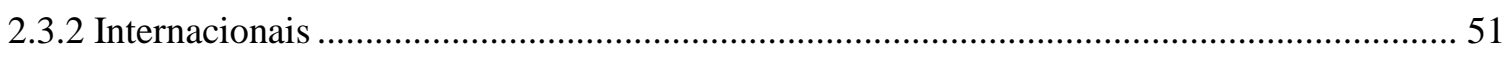

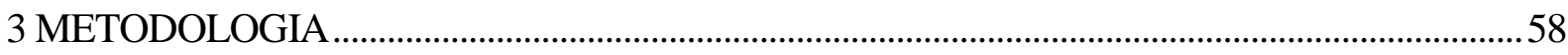

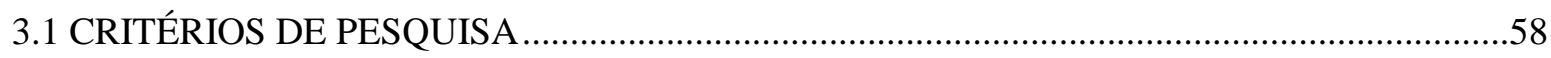

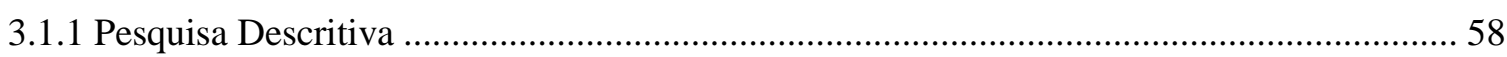




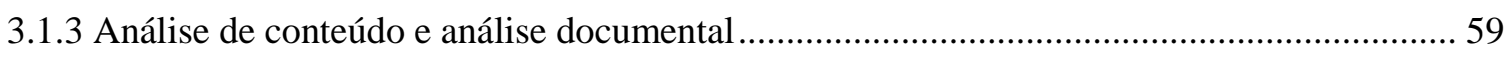

3.2 COLETA DE DADOS E SELEÇÃO DAS PERGUNTAS ANALISADAS ..............................61

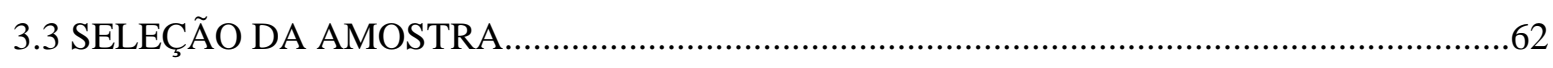

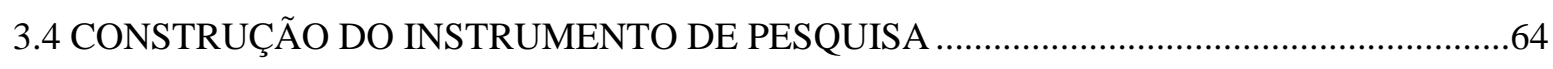

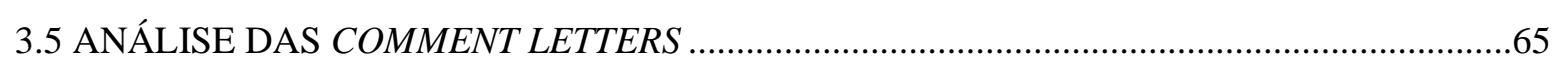

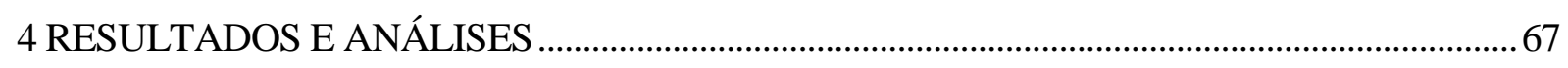

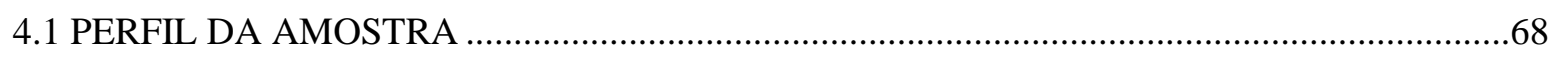

4.2 NÍVEL DE CONCORDÂNCIA E DISCORDÂNCIA .............................................................72

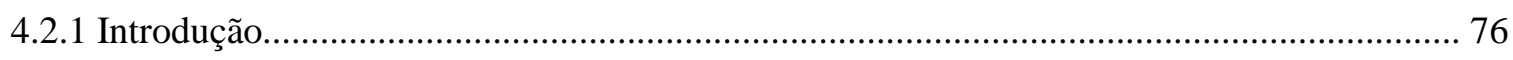

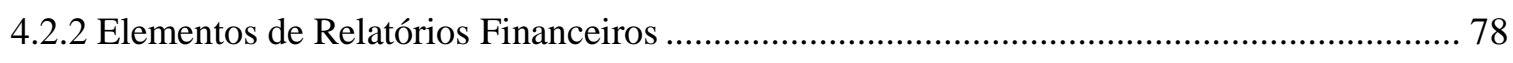

4.2.3 Orientação Adicional de Apoio as Definições de Ativo e Passivo ...................................... 80

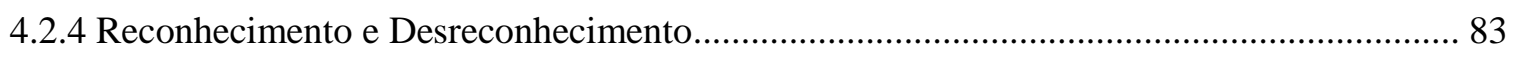

4.2.5 Definição de PL e Distinção de Passivo e Instrumento de Capital ..................................... 85

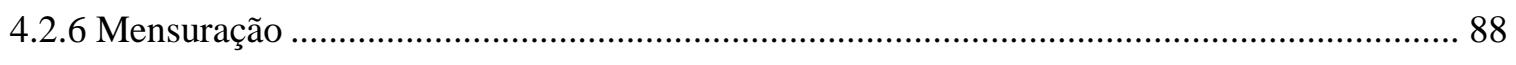

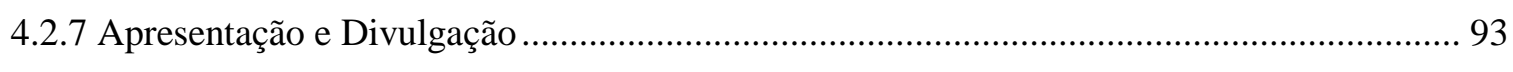

4.2.8 Apresentação na DRA - Lucros e Perdas e Outros Resultados Abrangentes ........................ 96

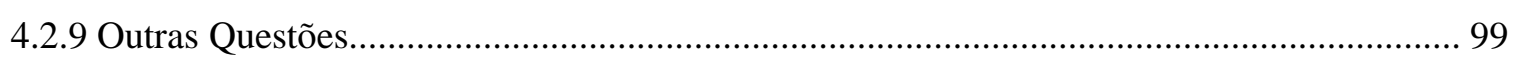

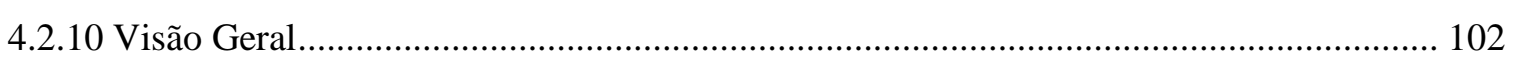

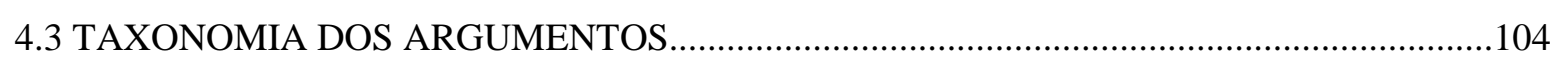

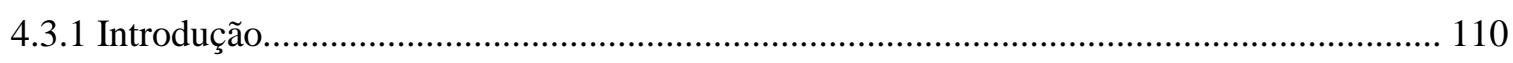

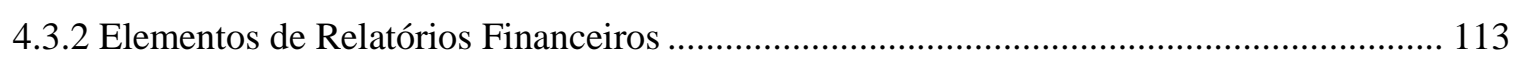

4.3.3 Orientação Adicional de Apoio as Definições de Ativo e Passivo .................................... 117

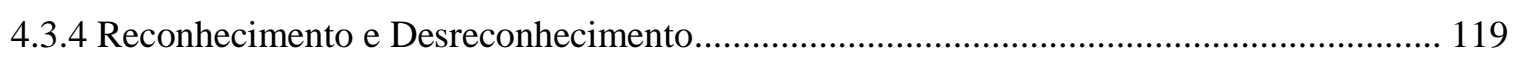

4.3.5 Definição de PL e Distinção de Passivo e Instrumento de Capital ...................................... 122

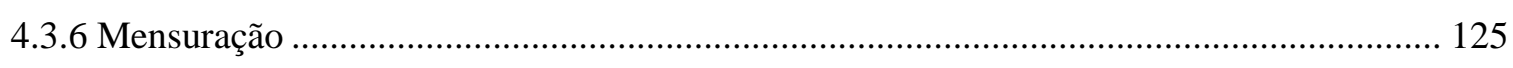

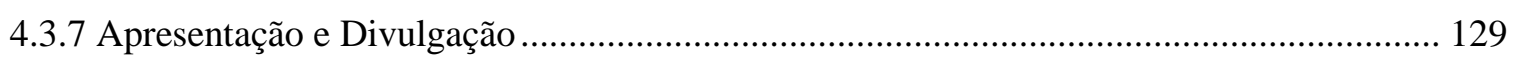

4.3.8 Apresentação na Demonstração do Resultado Abrangente - Lucros ou Perdas e Outros

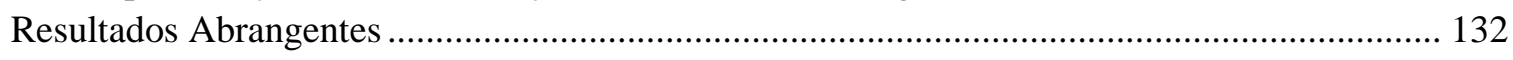

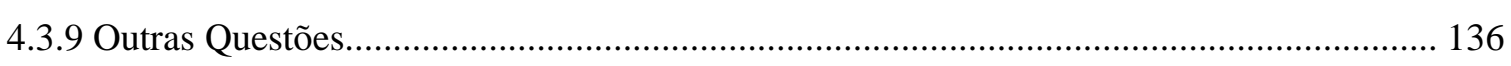

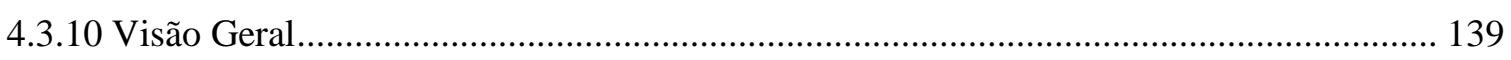

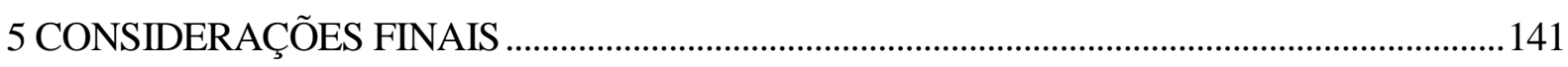

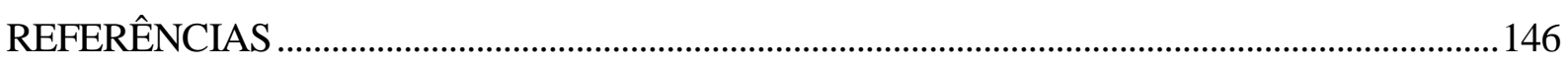

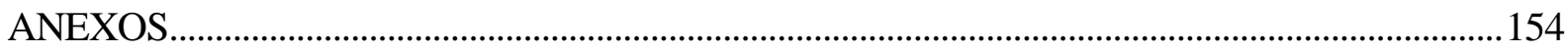

ANEXO A - RESUMO DO DISCUSSION PAPER - DP/2013/1 …........................................155

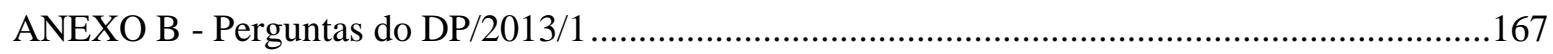


ANEXO C - Resumo das Decisões Provisórias 173

APÊNDICES

188

APÊNDICE A - Relação de comment letters recebidas pelo IASB 


\section{INTRODUÇÃO}

\subsection{CONTEXTUALIZAÇÃO}

A Conceptual Framework for Financial Reporting (Estrutura Conceitual), emitida pelo Internacional Accounting Standard Board (IASB), estabelece conceitos que suportam a preparação e apresentação das demonstrações financeiras e tem como objetivo auxiliar o IASB no desenvolvimento e revisão de normas contábeis (IFRS), bem como na promoção da convergência das normas e procedimentos relativos à apresentação das demonstrações financeiras.

A primeira estrutura conceitual emitida em nível internacional, ocorreu em 1989, ainda pelo antecessor do IASB, o International Accounting Standard Committee (IASC). O desenvolvimento dessa estrutura conceitual se deve, em grande parte, aos esforços do IASC/IASB na busca pela harmonização e convergência das práticas contábeis, pelo desenvolvimento de princípios contábeis europeus e principalmente pelas contribuições advindas do Financial Accounting Stantard Board (FASB), através do Referencial Conceitual (SFAC 1, SFAC 2, SFAC 5, SFAC $6{ }^{1}$ e SFAC 7) emitido a partir do final da década de 1970.

Fato é que a busca por princípios e por comparabilidade dos relatórios financeiros em nível internacional, levou o IASB ao desenvolvimento de um arcabouço teórico que desse suporte para emissão das normas internacionais. Dessa forma, a estrutura conceitual auxilia os normatizadores e os demais usuários das demonstrações financeiras.

Como fruto dos esforços conjuntos do FASB e IASB na busca pela convergência, foi iniciado, em 2004, um projeto conjunto para revisar suas estruturas conceituais. Em 2010, o IASB e o FASB emitiram dois capítulos da estrutura conceitual revisada, na qual esboçavam: O Objetivo de Relatórios Contábeis de Uso Geral; e as Características Qualitativas das

Informações Financeiras Úteis. Esses capítulos entraram em vigor logo após sua publicação e, no mesmo ano, os trabalhos de revisão foram suspensos.

Tendo em vista que a consulta pública realizada pelo IASB em 2012 apontou como prioridade a retomada do projeto, o IASB reiniciou os trabalhos, porém sem a participação do FASB. Foram identificados diversos problemas com a estrutura conceitual existente, tais como: áreas importantes que ainda não são cobertas pela atual estrutura conceitual; a

\footnotetext{
${ }^{1}$ SFAC 6 substituiu as SFACs 3 e 4.
} 
orientação em algumas áreas não é clara e alguns aspectos da atual estrutura conceitual estão desatualizados e não refletem os pensamentos do IASB.

Foi emitido e disponibilizado ao público, em 2013, o Discussion Paper - DP/2013/1 A Review of the Conceptual Framework for Financial Reporting - para que os usuários da informação contábil pudessem remeter opiniões acerca da proposta, para a qual foram recepcionadas comment letters, até 14 de janeiro de 2014 e disponibilizadas para acesso público, no sitio eletrônico do IASB, até 31 de janeiro do mesmo ano. Em principio, as opiniões serão consideradas pelo IASB, no desenvolvimento da proposta para o Exposure Draft da Estrutura Conceitual revista.

Nesse contexto, esta pesquisa pretende analisar a percepção dos usuários da informação contábil acerca da proposta de revisão da Estrutura Conceitual da contabilidade.

\subsection{JUSTIFICATIVA E RELEVÂNCIA DA PESQUISA}

A Estrutura Conceitual do IASB é um documento que, entre as suas finalidades, auxilia o IASB na elaboração de futuras IFRSs e na revisão de normas existentes. Ela consiste em um conjunto de conceitos e orientações que embasam as decisões do referido órgão na operacionalização de seu trabalho e na promoção da convergência, auxilia entidades normativas nacionais a elaborar suas normas e outros usuários a interpretar as informações evidenciadas nas demonstrações financeiras.

A partir da Segunda Guerra mundial, diversos países possuíam o seu próprio quadro conceitual. Existiam diversas Estruturas Conceituais que orientavam a emissão de Normas contábeis, tanto em nível nacional, quanto internacional, fossem elas baseadas em regras ou em princípios. Schipper (2003) afirma que a normatização do FASB, é guiada pela sua estrutura conceitual, tal como estabelecidas nas declarações de seus conceitos.

Segundo Schipper (2003), reconhecimento e mensuração são requisitos das normas contábeis que devem ser baseadas nas características qualitativas da informação contábil. O conceito geral é a utilidade da informação, apoiada por relevância, confiabilidade ${ }^{2}$ e comparabilidade. O desejo de atingir a comparabilidade e a sua contrapartida ao longo do tempo, a consistência, é a razão de ter padrões de relatórios. Isto é, se as coisas semelhantes são contabilizadas da mesma maneira, quer através de empresas ou ao longo do tempo, torna-

\footnotetext{
${ }^{2}$ Substituída pela Representação Fiel na Estrutura Conceitual emitida em 2010 pelo FASB e IASB.
} 
se possível avaliar os relatórios financeiros de entidades diferentes, ou a mesma entidade, em diferentes pontos no tempo, de forma a discernir os eventos económicas subjacentes.

Dessa forma, diversos fatores - no transcorrer dos anos - influenciaram nas políticas e praticas contábeis adotadas pelos países, tais como: sistema legal, cultura, tipo de mercado de capitais e ambiente social. Contabilidade é formada por economia e política (WATTS; ZIMMERMAN, 1986), então a fonte de convergência internacional das normas contábeis é a maior integração transfronteiriça dos mercados e a política (BALL, 1995). Dirigir essa integração é a redução extraordinária dos custos de comunicação internacional e de transações.

Segundo Askary (2006), valores compartilhados dentro das fronteiras nacionais têm o potencial de promover e sustentar diferenças significativas no comportamento social e em artefatos sociais, tais como as práticas contábeis. Diferenças de práticas contábeis são manifestações da vida social nacional de diferentes sistemas. Em virtude disso, a cultura e contabilidade são indissociáveis.

Askary (2006) complementa que Gray 1988 converteu valores culturais e sociais de Hofstede em valores contábeis e postulou uma relação entre eles. O modelo de Gray propôs que todas as decisões de políticas contábeis, em nível nacional, são feitas em resposta a valores culturais que são explicáveis em termos do estudo de Hofstede. Dessa forma os valores contábeis que devem sustentar um sistema contábil compatível serão diferentes das que são extraídos no que diz respeito à listagem de países Gray. A primeira hipótese de Gray é que quanto maior a classificação dos países em termos de individualismo e menor a classificação em termos de evitar a incerteza e a distância do poder, então é mais provável que seja classificado altamente em termos de profissionalismo. Uma segunda concepção de Gray é que os países em desenvolvimento têm uma tendência em direção ao controle legal.

Bence (1996) ressalta que os quadros conceituais haviam deixado de considerar os aspectos culturais e, em vez disso, tratando contabilidade financeira como uma atividade técnica, sem valor. No entanto, há uma grande quantidade de pesquisas acadêmicas que vê os relatórios financeiros como um processo social dependente dos valores dos participantes do processo de informação financeira. Qualquer consideração sobre cultura e política incluirá uma análise dos objetivos dos participantes do processo de informação financeira.

Ball (2005) ressalta que pelo menos três grandes vantagens da convergência as normas contábeis internacionais - contabilidade baseada em princípios - são que levam a emergir voluntariamente: economias de escala; a proteção que dão auditores contra os gestores que desempenham um jogo "opinion shopping"; eliminam externalidades informacionais 
decorrentes da falta de comparabilidade. Tais vantagens implicam em esperar que surja certo grau de uniformidade das normas contábeis.

Segundo Niyama (2010), de uma forma geral, tanto em nível de empresas, quanto em nível de entidades profissionais, clientes, instituições de ensino, há um consenso favorável para uma harmonização de padrões contábeis que facilite a comunicação e contribuam para reduzir as diferenças internacionais no financial reporting, permitindo a comparabilidade das informações.

Nesse contexto, o IASB ressalta que a Estrutura Conceitual estabelece os conceitos que fundamentam a preparação e apresentação das demonstrações financeiras, tendo como objetivo ajudar o IASB através da identificação de conceitos que serão utilizados de forma consistente no desenvolvimento e revisão de IFRSs e ajudar outras partes a entender e interpretar as IFRSs existentes e desenvolver políticas contábeis quando nenhuma Norma ou Interpretação se aplicar especificamente a uma transação ou evento particular.

O processo normativo do IASB permite que os diversos agentes (de diversos países), interessados na elaboração de Relatórios Financeiros - Preparadores, Normatizadores, Academia, Reguladores e outros - participem da elaboração de normas, e desta vez, da alteração da Estrutura Conceitual, através das suas opiniões no tocante aos diversos elementos elencados na proposta da Estrutura Conceitual. Assim, pode-se elaborar um documento que seja eficiente para o IASB na elaboração de Normas que serão uteis para a elaboração de Relatórios Financeiros de alta qualidade e também, aos diversos agentes interessados na interpretação e aplicação das Normas contábeis.

Dessa forma, percebe-se a magnitude desta pesquisa, a qual evidenciará a relação do IASB com os Normatizadores, Preparadores, Academia, Reguladores e outros agentes, e, a participação destes, fornecendo suas opiniões concernentes às mudanças propostas, em virtude da desmedida relevância da Estrutura Conceitual, haja vista que poderá influenciar e afetar o conteúdo das normas contábeis em nível internacional. Ademais, essa pesquisa evidenciará os principais aspectos concernentes aos elementos da Estrutura Conceitual, as principais mudanças que poderão ocorrer de acordo com a proposta do IASB.

Esta pesquisa contribui para a literatura contábil de três formas: primeiro, contribui para a literatura sobre normatização contábil internacional, à medida que investiga o processo normativo do IASB, bem como a recepção das opiniões dos usuários da contabilidade e sua utilização na elaboração e alteração de normas; segundo, não foram encontradas pesquisas anteriores que se propuseram a investigar a revisão da estrutura conceitual do IASB e a opinião dos usuários em relação às mudanças propostas; e terceiro, a pesquisa ampliará a 
literatura sobre contabilidade internacional e convergência às normas do IASB, à medida que se propõe evidenciar as principais mudanças propostas no DP/2013/1. Por fim, os resultados deste estudo poderão trazer implicações para os pesquisadores, formuladores de padrões, investidores, professores, acadêmicos e demais usuários, reforçando a sua compreensão sobre o processo de convergência e seu impacto sobre a qualidade da informação contábil.

Esta pesquisa é aguçada pela aspiração de assinalar a evidência empírica sobre a Estrutura Conceitual da contabilidade. Conjectura-se um tema congruente e hodierno, devido às recentes mudanças no contexto da convergência contábil e ao apoio propiciado ao IASB no desenvolvimento e alteração de normas.

\subsection{PROBLEMA DA PESQUISA}

Com base no contexto previamente destacado, e nas razões elencadas, o problema de pesquisa pode ser descrito através da seguinte pergunta: (1) Qual o nível de concordância ou discordância dos usuários perante a proposta do DP/2013/1? (2) Quais as taxonomias dos argumentos utilizados para fundamentar a opinião dos respondentes, à luz da teoria contábil?

\subsection{OBJETIVOS DA PESQUISA}

De acordo com Kothari (2004), a finalidade da pesquisa é descobrir respostas para as perguntas (problema de pesquisa) através da aplicação de procedimentos científicos. O principal objetivo é descobrir a verdade que está escondida.

Para responder ao problema de pesquisa, este trabalho teve como objetivo geral analisar a percepção dos usuários da contabilidade sobre a proposta de revisão da Conceptual Framework for Financial Reporting propostos no Discussion Paper DP/2013/1 emitido pelo International Accounting Standard Board - IASB.

Em consonância com a finalidade principal desta pesquisa, a fim de atingir o objetivo geral proposto, foram estabelecidos os seguintes objetivos específicos:

a) Identificar o nível de concordância ou discordância dos usuários da informação contábil, em face da proposta de revisão da Conceptual Framework for Financial Reporting;

b) Identificar, classificar e avaliar as opiniões apresentadas pelos usuários acerca da revisão da Conceptual Framework for Financial Reporting do IASB, proposta no Discussion Paper 2013/1; 
c) Identificar e avaliar as taxonomias dos argumentos utilizados para a fundamentação das percepções dos respondentes, á luz dos argumentos da Teoria da Contabilidade;

d) Identificar e classificar o perfil dos respondentes e o nível de concordância/discordância com base no setor de atuação.

\subsection{ESTRUTURA DA PESQUISA}

Essa pesquisa está dividida em 4 partes: Parte 1, refere-se a introdução, abordando os objetivos geral e específicos a serem alcançados com a pesquisa e a justificativa para sua elaboração; Parte 2, consiste no referencial teórico, destacando os antecedentes históricos que culminaram na elaboração da Estrutura Conceitual do IASB, desde as contribuições advindas das principais entidades e pensadores norte-americanos na busca por Princípios, bem como o desenvolvimentos de Princípios Contábeis Europeus; Parte 3, apresenta o percurso metodológico que foi seguido no desenvolvimento da pesquisa; Parte 4, evidencia os resultados alcançados na investigação e a discussão destes e Parte 5, as considerações finais obtidas no decorrer da pesquisa.

\subsection{FORMULAÇÃO DA HIPÓTESE DA PESQUISA}

Para Bardin (2011) uma hipótese é uma afirmação provisória que nos propomos verificar (confirmar ou informar), recorrendo aos procedimentos de análise. Trata-se de uma suposição cuja origem é a intuição e que permanece enquanto não for submetida à prova de dados seguros.

Assim, para efeito dessa investigação, foram estabelecidas as seguintes hipóteses:

$\mathrm{H}_{0}: \mu<0,5$ - A média de concordância dos respondentes das perguntas do DP/2013/1 é menor que $50 \%$, isto é, a maioria dos respondentes discorda da proposta do IASB, no tocante a proposta de mudança da Estrutura Conceitual.

$\mathrm{H}_{1}: \mu \geq 0,5$ - A média de concordância dos respondentes das perguntas do DP/2013/1 é maior ou igual a 50\%, isto é, a maioria dos respondentes concorda com a proposta do IASB, no tocante a proposta de mudança da Estrutura Conceitual.

$\mathrm{H}_{0}: \mu<0,5$ - A média dos argumentos não teóricos (escopo) utilizados para fundamentar as respostas dos respondentes no tocante as perguntas do DP/2013/1 é menor que $50 \%$, isto é, a maioria dos respondentes utiliza argumentos teóricos, baseados em normas 
ou definições, para fundamentar suas opiniões no tocante a proposta de mudança da Estrutura Conceitual.

$\mathrm{H}_{1}: \mu \geq 0,5$ - A média dos argumentos não teóricos (escopo) utilizados para fundamentar as respostas dos respondentes no tocante as perguntas do DP/2013/1 é maior ou igual a $50 \%$, isto é, a maioria dos respondentes utiliza argumentos não teóricos, baseados na experiência pratica ou no que pensam para fundamentar suas opiniões no tocante a proposta de mudança da Estrutura Conceitual.

Por meio da técnica de análise de conteúdo foram analisadas 80 comment letters aquelas que respondiam todas as questões da pesquisa - de um total de 227 , recepcionadas pelo IASB até 14 de janeiro de 2014. Procedeu-se com a leitura das cartas e confecção do instrumento de pesquisa através da análise das 22 perguntas (segregadas em 44).

\subsection{DELIMITAÇÃO DA PESQUISA}

Segundo Niyama et al. (2012) a estrutura de trabalho do IASB é dividida em seis estágios: 1) definição de uma agenda; 2) planejamento do projeto; 3) desenvolvimento e publicação do discussion paper; 4) desenvolvimento e planejamento do exposure draft; 5) desenvolvimento e publicação do IFRS, e 6) procedimentos após uma IFRS ser publicada. Cada uma das etapas tem o objetivo de trazer maior participação do público para o processo normativo, tornando-o, assim, um processo mais neutro.

Da mesma maneira, a revisão da Estrutura Conceitual adota o mesmo roteiro. O projeto foi recomeçado em 2012, e o IASB pretende completar as revisões até o final de 2015. Por esse motivo, o Discussion Paper 2013/1 será considerado como a versão final do pronunciamento para análise dos resultados, assinalando assim uma limitação desta pesquisa. Esse fato parte dos seguintes axiomas: a) acredita-se que as diferenças emanadas da relação DP/2013/1 versus versão final, não serão significativas para a pesquisa; b) em razão da data limite permitida para apresentação desta pesquisa, não é possível aguardar a versão final da Estrutura Conceitual, e c) o principal objetivo desta pesquisa pode ser alcançado através da análise do Discussion Paper e das Comment Letters referentes a ele, sem acometer os resultados. 


\section{REVISÃO DE LITERATURA}

Watts e Zimmerman (1986) ressaltam que o objetivo da teoria da contabilidade é explicar e prever a prática contábil. O desenvolvimento e a natureza da contabilidade estão intimamente ligados à auditoria e práticas de auditoria estão incluídas como parte da prática contábil. Explicação significa fornecer razões para a prática observada. Previsão de prática contábil significa que a teoria prevê fenômenos contábeis não observados. Fenômenos não observados não são necessariamente fenômenos futuros; eles incluem fenômenos que ocorreram, mas sobre o qual evidências sistemáticas não têm sido recolhidas. Hendriksen e Van Breda (1999) acrescentam que a teoria da contabilidade concentra-se no conjunto de princípios subjacentes e, presumivelmente, fundamentais para a prática contábil.

$\mathrm{O}$ advento da Contabilidade se deu por ocasião da enorme expansão da indústria no final do século XIX e o início do século XX, particularmente nos Estados Unidos e na Inglaterra. A produção americana aumentou substancialmente e as informações financeiras, que tinham sido geradas principalmente para fins de gestão, passaram a serem demandadas cada vez mais por acionistas, investidores, credores e pelo governo. As grandes exigências de capital também conduziam à criação da sociedade por ações e, com o tempo, a auditorias obrigatórias (HENDRIKSEN; VAN BREDA, 1999).

Assim, várias mudanças haviam feito com que o sistema contábil estabelecido por Luca Pacioli assumisse uma forma mais adequada às necessidades das grandes sociedades anônimas industriais. Nesse contexto, havia a necessidade de um arcabouço teórico que desse suporte a essas transações - os Princípios Contábeis.

\subsection{EVOLUÇÃO HISTÓRICA DA ESTRUTURA CONCEITUAL DOS EUA}

Wolk, Dodd e Tearney (2004) seguimentam a evolução das propostas de conjunto dos princípios contábeis norte-americanos em 04 (quatro) fases: a) contabilidade nos EUA antes de 1930; b) ano de formação, 1930 à 1946; c) período pós-guerra, 1946 à 1959; e, d) período moderno, 1959 ao presente.

Durante esse período, teve-se a atuação de dois grupos de entidades de classes que efetivamente contribuíram para o surgimento da estrutura conceitual da contabilidade do FASB e IASB: 1) American Accounting Association e 2) American Institute of Certified Public Accoutants. 


\subsubsection{American Accounting Association e American Institute of Certified Public Accoutants}

Paulo (2002) afirma que o primeiro deles refere-se à American Accounting Association (AAA), que teve como antecessora a American Association of University Instructors in Accounting (AAUIA) fundada em 16 de dezembro de 1916. A alteração do nome da associação, em 1936, de AAUIA para AAA, foi responsável também por uma mudança no seu enfoque de atuação, isto é, de uma associação de professores para uma organização de pesquisa contábil.

Por outro lado, o American Institute of Certified Public Accoutants (AICPA) foi criado em 1959, e teve vários predecessores, sendo o mais antigo deles a American Association of Public Accountants (AAPA), criada em 1887, em Nova York, e o American Institute of Accounting (AIA), criado em 1916. Ao longo dos anos, vinculados a essas associações, foram criadas 03 (três) entidades com o objetivo de desenvolver estudos para uma melhor condução da prática contábil: a) O Committee on Accounting Procedure (CAP) surgiu em 1936, ainda no AIA, que durou até a criação do AICPA em 1959; b) O Accounting Principles Board (APB) criado, em 1959, como uma resposta às criticas feitas por Leonard Spacek, da Arthur Andersen \& Company, sobre falhas no esclarecimento ao público a respeito das limitações da contabilidade e c) a Financial Accounting Foundation (FAF) que subordina o FASB, criada em 1973 (SCHMIDT, 2000; WOLK; DODD; TEARNEY, 2004).

\subsubsection{Primeiras Contribuições para a Estrutura Conceitual}

As primeiras tentativas de desenvolver um "marco conceitual" na literatura contábil nos EUA, se deu por William A. Paton e John B. Canning. Em sua tese de doutorado, publicada em 1922, intitulada Accounting Theory, Paton apresentou uma reafirmação da teoria da contabilidade e o final do uso da contabilidade a custo histórico nos EUA (WOLK, 2009). O professor John Canning fez uma contribuição valiosa à teoria da contabilidade em seu livro Economics of Accountancy, no qual, entre outros fatos, compara o pensamento contábil da época à teoria econômica, particularmente à teoria exposta pelo economista americano Irving Fisher (HENDRIKSEN; VAN BREDA, 1999; OLIVEIRA, 2003; PAULO, 2002). Caning foi o primeiro a desenvolver e apresentar um quadro conceitual para avaliação e mensuração de ativos fundada explicitamente na expectativa futura, conforme Zeff (1999).

Hendriksen e Van Breda (1999) ressaltam que o final da Primeira Guerra Mundial, em 1919, liberou, uma demanda reprimida de bens de consumo, instalações industriais e 
equipamentos que alimentaram uma explosão de investimentos na NYSE com a quadruplicação do volume médio negociado de 1922 a 1929. No curto espaço de apenas dois meses, a expansão terminou e iniciou-se a Grande Depressão. O investimento privado caiu $90 \%$, a produção diminuiu $56 \%$ e o desemprego alcançou a taxa de $24 \%$.

A quebra da NYSE, ocorrida em 1929, causou um grande abalo na confiabilidade das demonstrações contábeis, que foram muito criticadas, inclusive nos meios acadêmicos (SCHMIDT, 2000), devido a falta de uniformidade das práticas contábeis (HENDRIKSEN; VAN BREDA, 1999).

As reavaliações acima do custo histórico - writeups - eram usadas para gerar receita ou para aliviar as contas de receitas de encargos importantes, que seriam debitados à conta de reserva de reavaliação que havia sido creditado com a writeups (HEALY, 1939). Healy - que se tornaria um dos cinco comissários da SEC - concluiu que todas as partidas para cima do custo histórico eram verdadeiramente hediondas, em conformidade com Zeff (2007).

Wolk, Dodd e Tearney (2004) ressaltam que surgiram dúvidas a respeito das práticas contábeis, se elas contribuíram para decisões de investimento em negócios ruins, mas o caso nunca foi provado. No entanto, a depressão e a eleição de Franklin D. Roosevelt para a presidência, em 1932, e a promulgação da legislação do New Deal contribuíram para enormes mudanças na contabilidade.

Um esboço formal dos "cinco princípios contábeis gerais" foi preparado pelo AICPA e aprovado pelo comitê da NYSE em 22 de setembro de 1932. Este documento representava a primeira tentativa formal para desenvolver "os princípios de contabilidade geralmente aceitos" (GAAP). De fato, o comitê do AICPA cunhou a frase "accepted principles of accounting" e os primeiros cinco princípios foram posteriormente incorporados como capítulo 1 do Accounting Research Bulletins (ARB) 43, de acordo com Wolk, Dodd e Tearney (2004).

A Securities and Exchange Commission (SEC) foi criada em 02 de julho de 1934 (ZEFF, 2007) pelo Congresso Americano (WOLK; DODD; TEARNEY, 2004) e foi encarregada de administrar a Lei dos Títulos de $1933^{3}$ e a Lei dos Valores Mobiliários de 1934, sendo que a segunda estabeleceu a SEC. Essa legislação atribuiu à SEC (além de outras funções) a competência para definir as regras e regulamentos para reger a elaboração de relatórios contábeis - determinando procedimentos contábeis e de auditoria - e divulgação de informações financeiras, bem como a forma de apresentação das demonstrações financeiras, pelas empresas cujos títulos eram cotados em qualquer bolsa de valores nacional, incluindo o

\footnotetext{
${ }^{3}$ O Federal Trade Commission (FTC) administrou a Lei dos Títulos de 1933, desde sua criação até 1 de setembro de 1934, quando esta autoridade foi transferida para a SEC (ZEFF, 2007).
} 
conteúdo de prospectos e relatórios periódicos (SCHMIDT, 2000; ZEFF, 2007). Porém, devido a controvérsias, a SEC delegou autoridade ao AIA, no que se refere aos assuntos contábeis (SCHMIDT, 2000).

De acordo com Zeff (2007), a pessoa que efetivamente consolidou a política da SEC em insistir na contabilidade a custo histórico foi Robert E. Healy. Antes de se tornar um dos cinco comissionários fundadores da SEC, em 1934, Healy tinha sido Procurador Geral da Federal Trade Commission (FTC) 1928-1934 e dirigiu por seis anos, a investigação realizada pelo Congresso da FTC - das manipulações do mercado por empresas de utilidade pública, com ênfase em práticas contábeis duvidosas. No final, o registro da investigação acumulou 95 volumes.

\subsubsection{A Era do Committee on Accounting Procedure (CAP)}

Em conformidade com Paulo (2002), o CAP foi constituído em 1936, pelo AIA, cujo objetivo de trabalho era esboçar as propostas do AIA sobre os Princípios Contábeis Geralmente Aceitos.

Provavelmente a primeira tentativa institucional para lançar bases para uma Estrutura Conceitual foi a Tentative Statement of Accounting Principles Affecting Corporate Reports, emitida em 1936 pelo comitê executivo da AAA e publicado na The Accounting Review. A principal razão para a elaboração do termo "Tentative Statement" - um "hino ao custo histórico" - foi fornecer orientação autoritativa a recém criada SEC (ZEFF, 1999).

Zeff (1972) declara que em 1938-1939, o AIA se tornou ainda mais ativo na orientação à SEC, quando autorizou o CAP a emitir Boletins de Pesquisas Contábeis. Em uma de suas primeiras decisões, o comitê rejeitou a opção de desenvolver um conjunto abrangente de princípios contábeis (uma espécie de "marco conceitual"), porque o projeto levaria talvez cinco anos para ser concluído, período em que a SEC poderia perder a paciência com o comitê e, por sua vez, começar a emitir suas próprias regras de contabilidade.

Zeff (1999) sustenta que uma consequência da Tentative Statement, publicada pelo AAA em 1936 foi, talvez, a mais influente monografia na literatura contábil do EUA, An Introduction to Corporate Accounting Standards, escrita por Paton e A. C. Littleton, dois dos melhores professores acadêmicos daqueles dias, e publicado em 1940 pela AAA. Uma elegante explicação e racionalização do modelo contábil do custo histórico que já era amplamente aceito nos EUA, usada por muitos anos nos cursos de contabilidade em todo o país. A monografia de Paton e Littleton, como veio a ser conhecida, provavelmente fez tanto 
quanto qualquer publicação para perpetuar o uso da contabilidade a custo histórico nos EUA. Essa monografia também popularizou o uso do custo corrente e receitas.

Diversas vezes, entre os anos 40 e 50, durante o mandado do CAP, propostas para desenvolver um conjunto de conceitos contábeis foram expressos e em 1940 o departamento de pesquisa do instituto emitiu uma revisão de oito páginas sobre os princípios básicos de contabilidade (ZEFF, 1999).

Segundo Hendriksen e Van Breda (1999), com o fim da Segunda guerra mundial, em 1945, iniciou-se uma demanda reprimida de bens e serviços por consumidores que fez a economia deslanchar. O emprego expandiu-se e a riqueza cresceu. A prosperidade da classe média americana convenceu muitas pessoas a aplicarem no mercado de ações. Wolk, Dodd e Tearney (2004) acrescentam que em 1940 havia aproximadamente 4 milhões de investidores em ações. Em 1952 o número tinha crescido para 7 milhões, e em 1962 esse número havia subido para 17 milhões.

Relatórios financeiros das companhias tornaram-se uma importante fonte de informação para tomada de decisões (WOLK; DODD; TEARNEY, 2004) e os investidores, naturalmente, esperavam que maiores lucros por ação indicassem tratar-se de uma empresa melhor. Em vez disso, como vieram a descobrir, diferenças de lucro frequentemente significavam pouco mais do que uma forma distinta de contabilizar algum eventos (HENDRIKSEN; VAN BREDA, 1999).

O primeiro problema foi a falta de comparabilidade e uniformidade dos lucros divulgados (WOLK; DODD; TEARNEY, 2004). Esse fato residia na disponibilidade de muitas alternativas de divulgação para a administração de uma empresa nessa época (HENDRIKSEN; VAN BREDA, 1999).

Apesar da emissão de 51 ARBs, 4 ATBs e da grande importância destas séries documentadas de princípios contábeis, problemas como fraudes, falta de uniformidade e de comparabilidade continuaram a existir e levaram o CAP a perda de credibilidade e, por conseguinte, sua substituição pelo APB.

De acordo com Hendriksen e Van Breda (1999), novamente a AAA assumiu a liderança publicando sua revisão, em 1948, dos Princípios Preliminares, agora rebatizados de Accouting Concepts and Standards. O Comitê de Procedimentos Contábeis do AIA também reiniciou seu trabalho e em 1953 já havia produzido 17 novos boletins. Em 1959 o instituto de pesquisa do AIA foi reorganizado, tendo como objetivo, entre outros, atacar os problemas maiores da contabilidade financeira quanto ao estabelecimento de postulados básicos; 
formulação de princípios amplos; desenvolvimento de regras ou outras normas para a aplicação de princípios em situações específicas e pesquisa.

\subsubsection{A Era do Accounting Principles Board (APB)}

Zeff (1999) ressalta que em seu relatório pioneiro publicado em 1958, o comitê propôs a criação do APB para substituir o CAP e uma divisão de pesquisas para apoiar o APB. O comitê identificou quatro grandes níveis sobre os quais a contabilidade financeira deveria ser abordada: Postulados, Princípios, Regras ou outras orientações para aplicação dos princípios para situações específicas. A primeira prioridade da divisão de pesquisa foi a realização de estudos sobre postulados contábeis e princípios contábeis amplos.

O AICPA iniciou, em 1961, suas publicações sobre princípios contábeis e o corpo permanente de pesquisa, sob a direção de Maurice Moonitz da University of California, produzindo os Accounting Research Studies - ARS, sendo que os de maior repercussão foram os ARS 1, ARS 3, ARS 7. O ARS 1, publicado em 1961, intitulado The Basic Postulates of Accounting, apresentou 14 postulados (SCHMIDT, 2000). Ele consistiu em uma explicação e exposição dos três níveis de Postulados Contábeis, tratando o ambiente, e os postulados: continuidade, objetividade, consistência, unidade monetária, materialidade, conservadorismo e disclosure (ZEFF, 1999).

Não ficou claro se o estudo de Moonitz favorecia a contabilidade a custo histórico ou uma versão da contabilidade a valor corrente. Porém, muitos leitores acharam esse estudo muito abstrato e geral para envolver seus interesses e pensamento crítico (ZEFF, 1999).

O ARS 3 foi publicado por Moonitz em 1962, em conjunto com Robert T. Sprouse, denominado A Tentative Set of Broad Accounting Principles for Business Enterprises (SCHMIDT, 2000). Baseado nos postulados de Moonitz, os autores argumentaram que menos confiança deveria ser colocada sobre o conceito de realização como uma característica essencial da contabilidade e que o uso do valor corrente deveria ser expandido, o qual, na visão da longa antipatia da SEC para com reavaliações além do custo histórico, imediatamente tornou-se controverso, senão censurável. Sprouse e Moonitz defenderam o uso do custo corrente de reposição para inventários de mercadorias, edificações e equipamentos, bem como o uso do valor presente descontado para recebíveis e pagamentos a serem liquidados em dinheiro (ZEFF, 1999).

O AICPA rejeitou os ARSs 1 e 3, dizendo que eram radicalmente diferentes da proposta de Princípios Contábeis Geralmente Aceitos existentes e, portanto, eram 
inaceitáveis. Um novo estudo foi solicitado, para examinar princípios contábeis existentes, resultando no ARS 7, que não provou ser mais do que um inventário de princípios, práticas e métodos contábeis existentes no APB e CAP (BELKAOUI, 2004).

O período que segue a partir de 1966 é caracterizado por um abandono temporário da busca por princípios contábeis de caráter universal e o desenvolvimento de conceitos básicos de contabilidade que constituem a "Estrutura conceitual de Contabilidade" e a proliferação de soluções de problemas específicos (PAULO, 2002).

\subsubsection{A Statement of Basic Accounting Theory}

$\mathrm{O}$ ataque de William Vatter ao enfoque de postulados e princípios refletiu-se num novo documento publicado em 1966 pela AAA (HENDRIKSEN; VAN BREDA, 1999) o qual se refere a uma monografia pioneira, intitulada A Statement of Basic Accounting Theory (ASOBAT), escrita por um comitê de nove membros, composto por oito profissionais da academia e um prático. Esse documento foi o primeiro sinal de aceitação institucional dos objetivos da utilidade da decisão (ZEFF, 1999; ZEFF, 2013), o qual redirecionou atenção longe das inerentes virtudes do modelo de avaliação de ativo em direção à utilidade da decisão das demonstrações financeiras (ZEFF, 1999). Com isso, o ASOBAT transformou-se no primeiro, dentre os novos pronunciamentos de teoria da contabilidade, a orientar-se para o usuário, pois insistia na necessidade de que os desejos dos usuários fossem considerados prioritários em relação aos pontos de vista e às opiniões dos especialistas (HENDRIKSEN; VAN BREDA, 1999).

Fertig (1967, apud ZEFF, 2013) ressalta que sequer foi realizada uma pesquisa bibliográfica, tendo em vista que não se refere a nenhuma literatura anterior. Os objetivos de contabilidade - como relatados no documento - são baseados em observações do comitê da sociedade sobre as funções de contabilidade e estabelece utilidade da informação como critério básico pelo qual as informações contábeis são julgadas.

Zeff (1999) afirma que o comitê também colocou ênfase no futuro, sugerindo que a informação contábil para usuários externos deveriam refletir suas necessidades pelas mensurações relatadas e formulações que seriam relevantes na elaboração de previsões sem implicar que a informação fornecida fosse adequada para tais previsões. O comitê julgou uma serie de áreas com problemas contábeis. Em um desses mais importantes julgamentos, evidencia-se o custo histórico versus valor corrente, em que o comitê concluiu que depois de pesar a verificabilidade contra relevância, os relatórios financeiros deveriam apresentar 
informações extraídas de ambos os modelos. A apresentação de informações históricas por si só exclui o impacto total do ambiente sobre a firma. Apresentação do custo corrente só obscurece o registro de transações do mercado consumado. O comitê recomendou que os dois tipos de informações deveriam ser apresentados em um relatório multivariado em que os dois tipos de informações aparecem em colunas adjacentes.

O Quadro 1 mostra os Objetivos, Padrões (Relevância, Verificabilidade, Ausência de Viés e Quantificabilidade) e Diretrizes elencados no ASSOBAT.

\section{Quadro 1 - A Statement of Basic Accounting Theory (ASOBAT)}

\begin{tabular}{|c|c|}
\hline \multirow{4}{*}{ Objetivos } & $\begin{array}{l}\text { Tomar decisões a respeito do uso de recursos limitados, incluindo a identificação de áreas } \\
\text { cruciais de decisão, e a determinação de objetivos e metas, ou seja, decisões de acionistas, } \\
\text { credores e outros a respeito de alternativas de investimento. }\end{array}$ \\
\hline & $\begin{array}{l}2 \text { Direcionar e controlar eficazmente os recursos humanos e materiais de uma organização, } \\
\text { ou seja, decisões da administração em relação à empresa. }\end{array}$ \\
\hline & $\begin{array}{l}3 \text { Manter a informação a respeito da gestão de recursos, isto é, a função de custódia da } \\
\text { administração. }\end{array}$ \\
\hline & $\begin{array}{l}4 \text { Facilitar funções e controles sociais, ou seja, facilitar as operações da sociedade organizada } \\
\text { para o bem-estar de todos. }\end{array}$ \\
\hline \multirow{4}{*}{ Padrões } & 1 Relevância, ou seja, deve estar associado, em bases úteis, à ação que visa facilitar. \\
\hline & $\begin{array}{l}2 \text { Verificabilidade, isto é, indivíduos qualificados, agindo independentemente, devem chegar } \\
\text { ao mesmo resultado. }\end{array}$ \\
\hline & $\begin{array}{l}3 \text { Ausência de viés, ou seja, não deve favorecer um conjunto de usuários às expensas de } \\
\text { outro conjunto. }\end{array}$ \\
\hline & $\begin{array}{l}4 \text { Quantificabilidade, ou seja, deve ser possível mensurar, mesmo que não necessariamente } \\
\text { em termos monetários. }\end{array}$ \\
\hline \multirow{5}{*}{ Diretrizes } & 1 Adequação ao uso esperado. \\
\hline & 2 Divulgação de relações significativas. \\
\hline & 3 Inclusão de informações sobre o ambiente. \\
\hline & 4 Prática uniforme dentro de cada entidade e entre entidades. \\
\hline & 5 Práticas uniformes de um período a outro. \\
\hline
\end{tabular}

Fonte: Hendriksen e Van Breda (1999).

Alguns desses elementos, tais como relevância, ausência de viés, uniformidade, entre outros, mais tarde viriam a fazer parte do referencial conceitual do FASB (Conceptual Statement) e da Estrutura Conceitual do IASB.

\subsubsection{APB Statement N 4}

Em novembro de 1970, os sócios de três das oito maiores empresas de contabilidade, escreveram cartas ao AICPA, Presidido por Marshall S. Armstrong, em que criticavam o 
desempenho do APB. As três empresas deram um forte sinal de que não tinham mais confiança no APB. As cartas foram escritas por Ralph E. Kent, o sócio-gerente da Arthur Young \& Company; Harvey E. Kapnick, o presidente da Arthur Andersen \& Co.; e Robert Trueblood, o presidente do grupo de política de Touche Ross \& Co ${ }^{4}$ (ZEFF, 2014a).

O AICPA formou dois comitês especiais nesse cenário de crise (ZEFF, 1999). O primeiro, foi o Grupo de Estudos para o Estabelecimento de Princípios Contábeis (Comitê de Wheat), presidido por Francis M. Wheat, um ex-comissário da SEC e um crítico de longa data da profissão contábil. O segundo grupo, "O Grupo de Estudos sobre os Objetivos de Demonstrações Financeiras", presidido por Robert M. Trueblood, sócio-gerente da Touche Ross \& Co (WOLK, DODD; TEARNEY, 2004). O primeiro grupo reuniu-se para recomendar melhorias no processo de estabelecimento desses princípios. Em seu relatório o comitê propôs um órgão independente em tempo integral conhecido como Financial Accounting Standard Board (FASB) sob as asas de uma nova fundação, a Financial Accounting Foundation (FAF) (ZEFF, 2014b).

A nova estrutura proposta era formada por uma organização sem fins lucrativos, chamada de Financial Accounting Founndation (FAF), que opera o FASB e seria copatrocinada por cinco grupos de interesses: 1) O Instituto Executivo Financeiro; 2) A Associação Nacional dos Contabilistas; 3) A Associação Americana de Contabilidade; 4) A Federação de Analistas Financeiros e 5) A Associação da Indústria de Segurança (BELKAOUI, 2004). A comissão propôs que o termo princípios fosse substituído pelo termo padrões, definidos como soluções de problemas de contabilidade financeira (HENDRIKSEN; VAN BREDA, 1999). O AICPA prontamente aprovou o relatório do Comitê de Wheat e criou o FASB para suceder o APB, em julho de 1973 (ZEFF, 1999), como responsável pela criação de Normas Contábeis (BELKAOUI, 2004).

O segundo grupo, "O Grupo de Estudos sobre os Objetivos de Demonstrações Financeiras", foi presidido por Robert M. Trueblood, sócio-gerente da Touche Ross \& Co (WOLK, DODD; TEARNEY, 2004). Conhecido também como Comitê de Trueblood, ele foi composto por lideres práticos, acadêmicos e usuários da informação contábil e foi encarregado de propor os objetivos fundamentais das demonstrações financeiras para orientar o fornecimento de informação financeira. Foi produzido um padrão normativo e não uma inferência tirada da prática (ZEFF, 1999).

\footnotetext{
${ }^{4}$ Kent e Trueblood foram presidentes do Instituto durante a década de 1960, e Trueblood tinha servido no APB. Kapnick dirigiu a empresa que tinha criticado no decorrer de longo período, o CAP e APB por sua incapacidade para enfrentar abertamente os principais problemas de contabilidade do dia.
} 
O relatório do Comitê de Trueblood, o qual foi emitido em outubro de 1973, adotou a abordagem da utilidade da decisão evidenciada no ASOBAT e focou ainda mais especificamente nos fluxos de caixa futuros. Segundo o relatório, um objetivo das demonstrações financeiras é fornecer informações uteis para os investidores e credores, para predizer, comparar e avaliar os fluxos de caixa potenciais em termos de quantidade, tempo e incertezas relacionadas (ZEFF, 1999). A adoção da abordagem do ASOBAT em grande parte se deve ao importante papel desempenhado por George H. Sorter, na elaboração do relatório de Trueblood. Ele era o diretor de pesquisa do Comitê de Trueblood, professor de contabilidade da Universidade de Chicago e tinha sido um dos mais influentes membros do comitê da AAA que tinha desenvolvido o ASOBAT (ZEFF, 1999).

O novo pronunciamento, intitulado Basic Concepts and Accounting Principles Underlying Financial Statements of Business Enterprises (APB 4) (HENDRIKSEN; VAN BREDA, 1999, p. 81) evidenciou, além dos Princípios, os objetivos da contabilidade, os aspectos e elementos básicos, mostrados no Quadro 2.

Quadro 2 - Basic Concepts and Accounting Principles Underlying Financial Statements of Business Enterprises (APB 4)

\begin{tabular}{|c|c|c|c|}
\hline \multirow{2}{*}{1} & \multirow{2}{*}{\multicolumn{2}{|c|}{$\frac{\overbrace{0}^{\circ}}{\stackrel{e}{e}}$}} & $\begin{array}{l}\text { Fornecer informação confiável sobre os recursos e obrigações econômicas e } \\
\text { alterações desses recursos e obrigações; ajudar a estimar o potencial de geração } \\
\text { de lucro de uma empresa. }\end{array}$ \\
\hline & & & $\begin{array}{l}\text { Relevância; facilidade de compreensão; possibilidade de verificação; } \\
\text { neutralidade; oportunidade; comparabilidade; inteireza. }\end{array}$ \\
\hline 2 & \multicolumn{2}{|r|}{ Aspectos básicos } & $\begin{array}{l}\text { Entidade contábil; empresa em funcionamento; mensuração de recursos e } \\
\text { obrigações econômicas; período de tempo; mensuração em termos monetários; } \\
\text { regime de competência; preço de troca; aproximação; julgamento; informação } \\
\text { financeira para uso genérico; demonstrações financeiras relacionadas; substância } \\
\text { acima da forma; materialidade. }\end{array}$ \\
\hline 3 & \multicolumn{2}{|c|}{ Elementos básicos } & Ativos; passivos; patrimônio líquido; receita; despesa; lucro líquido. \\
\hline \multirow{4}{*}{4} & \multirow{4}{*}{ 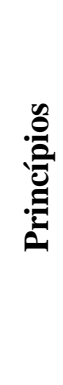 } & a Gerais & $\begin{array}{l}\text { Registro inicial de ativos e passivos; realização de receita; reconhecimento de } \\
\text { despesa; causa e efeito, alocação sistemática e racional, reconhecimento imediato; } \\
\text { unidade de medida. }\end{array}$ \\
\hline & & $\begin{array}{l}\text { Convenções } \\
\text { Modificadoras }\end{array}$ & Conservadorismo; ênfase no lucro; aplicação de julgamentos. \\
\hline & & $\begin{array}{l}\text { Operacionais } \\
\text { Amplos }\end{array}$ & $\begin{array}{l}\text { Seleção; análise; mensuração; classificação; registro; sumarização; ajuste; } \\
\text { comunicação. }\end{array}$ \\
\hline & & d Detalhados & Regras encontradas na prática. \\
\hline
\end{tabular}

Fonte: Hendriksen e Van Breda (1999) 
O comitê disse que as demonstrações financeiras deveriam servir primeiramente aqueles usuários que têm autoridade, habilidade ou recursos limitados para obter informações e que confiam nas demonstrações financeiras como sua principal fonte de informações sobre a atividade econômica das empresas. Enquanto o comitê dedicou atenção primária para os investidores e credores, ele também considerou gestores e empregados como vindo dentro do conjunto de usuários das demonstrações financeiras e concluiu que, enquanto usuários podem ser diferentes, suas decisões econômicas são similares. Cada usuário mensura sacrifício e benefícios em termos de desembolso atual ou futuro ou recebimento de caixa (ZEFF, 1999).

O comitê Trueblood considerou uma matriz ainda maior de bases de avaliação do que fez o comitê da AAA: custo histórico, valor de saída, custo corrente de reposição e fluxo de caixa descontado. O relatório tornou-se um tipo de modelo para o projeto da Estrutura Conceitual recém estabelecido pelo FASB (ZEFF, 1999). Diversas partes desse documento foram incorporadas ao Referencial Conceitual do FASB.

\subsubsection{A Era do FASB}

O FASB substituiu o APB como o normatizador dos EUA em julho de 1973, embora seus membros começassem a ter reuniões, já em março daquele ano. Ele seria um órgão independente, em tempo integral, com uma grande equipe de pesquisa, como recomendado pelo Grupo de Estudos de Wheat (Establishing Financial Accounting Standards, 1972) e aceito pelo Conselho do AICPA em junho de 1972, mesmo que o Grupo de Estudo de Wheat tenha dito que não acreditava que se pudesse esperar que Conselho realizasse um amplo programa de pesquisa, fundamentais para lidar com conceitos básicos de forma contínua, uma vez que acreditassem que este tipo de pesquisa seria mais bem empregado por aqueles no campo acadêmico Establishing Financial Accounting Standards (1972). O Conselho decidiu, no final de 1973, lançar o seu projeto do Quadro Conceitual, que tinha como pedra fundamental uma declaração sobre os objetivos das demonstrações financeiras por parte das empresas comerciais (ZEFF, 1999) e indicou que seria desenhado sobre o Relatório Trueblood (Task Force Appointed, 1973, apud ZEFF, 1999).

Em novembro de 1973 - em seu primeiro ano de operação como sucessor do APB - o FASB relatou que deveria enfrentar toda a hierarquia da Teoria da Contabilidade Financeira, iniciando com o relatório de Trueblood. Uma vez que os objetivos são acordados, o Conselho teve a intenção de dirigir-se para a hierarquia da Teoria da Contabilidade Financeira, incluindo características qualitativas, os tipos de informações para os usuários das 
demonstrações financeiras e os conceitos contábeis básicos (ZEFF, 1999). Um mês depois, em dezembro de 1973, o Conselho anunciou que seu projeto sobre Broad Qualitative Standards for Financial Reporting, o qual havia sido estabelecido em abril daquele ano, foi sendo ampliado com um novo e mais expressivo título, Conceptual Framework for Accounting and Reporting: Objectives, Qualitative Characteristics and Information (Task Force Appointed, 1973 apud ZEFF, 1999). Não havia, portanto dúvida que o Conselho pretendia desenvolver uma Estrutura Conceitual de pleno direito e o termo Conceptual Framework veio a ser amplamente usado para tal empreendimento (ZEFF, 1999).

Segundo Sprouse (1988, p. 124 apud ZEFF, 1999) dois fatores levaram o conselho a embarcar em uma Estrutura Conceitual: primeiro, o Conselho se sentiu obrigado a continuar o trabalho da Comissão de Trueblood; e segundo, era necessário um quadro de conceitos para ajudar o Conselho a direcionar os seis projetos técnicos de sua agenda inicial - pesquisa e desenvolvimento, contingências, leasing, conversão de moeda estrangeira, seguimento de negócio e materialidade.

Em junho de 1974, o FASB emitiu o primeiro memorando de discussão sobre o projeto Conceptual Framework for Accounting and Reporting, lidando com os objetivos e as características qualitativas recomendadas pelo Comitê de Trueblood (FASB, 1974; ZEFF, 2009, 2013) e realizou duas audiências públicas sobre os objetivos, apesar de a maior parte do trabalho ter sido feito pelo Grupo de Estudos Trueblood, em cujo relatório, Sprouse (1988) escreveu, colocou a "fundação" para estrutura conceitual do Conselho (ZEFF, 2013).

Em dezembro de 1976, o Conselho emitiu dois importantes documentos relacionados ao projeto Conceptual Framework. Um foi, Tentative Conclusions on Objectives of Financial Statements of Business Enterprises (FASB, 1976a), baseado na análise dos comentários recebidos e no testemunho da audiência pública realizada sobre o memorando de discussão de junho de 1974. O outro documento era um memorando de discussão de 360 páginas, intitulado Elements of Financial Statements and Their Measurement (FASB, 197b). O memorando de discussão sobre os elementos também incluiu um extensivo tratamento das características qualitativas da informação financeira e a mensuração desses elementos (ZEFF, 1999).

Entre 1974 e 1975, o FASB emitiu 30 publicações - oito memorando de discussão, sete relatório de pesquisa, oito exposure drafts, um convite para comentário e seis concepts statements - em seu enorme projeto Conceptual Framework, totalizando 3.000 páginas. Além disso, o conselho recebeu mais de 1.000 cartas de comentários em resposta a esses 
memorandos de discussão e exposure drafts, e realizou oito audiências públicas abrangindo 20 dias de testemunho (VAN RIPPER, 1994, apud ZEFF, 1999).

Nos anos seguintes, a partir de 1978, foram emitidos documentos conceituais do FASB, a saber, SFAC 1, SFAC 2, SFAC 3, SFAC 4, SFAC 5, SFAC 6 (substituiu SFAC 3 e SFAC 4) e SFAC 7, nas quais são apresentados os objetivos, características qualitativas, informações necessárias, fundamentos de contabilidade e divulgação, padrões de contabilidade e divulgação, interpretações de padrões e aplicações práticas a situações específicas por administradores e auditores.

\subsubsection{The Conceptual Statements}

O FASB emitiu seis Statements of Financial Accounting Concepts (SFAC), conhecidas como Concepts Statements, dos quais dois ( $n^{\circ} 4$ e 6$)$ representaram adaptações para entidades não empresariais. A proposta declarada pelo FASB para as SFACs era expor os objetivos e fundamentos que seriam base para o desenvolvimento da contabilidade financeira e dos relatórios financeiros. A estrutura conceitual é um coerente sistema de objetivos interrelacionados e fundamentais que é esperado para levar a padrões consistentes que prescrevem a natureza, função, e limites da contabilidade e dos relatórios financeiros. É esperado que seja útil ao interesse público pelo fornecimento de estrutura e direção para a contabilidade e relatórios financeiros. Além disso a estrutura conceitual facilita a prestação de informações financeiras imparciais, que sejam uteis para assessorar o mercado de capitais e outros mercados a funcionar eficientemente na alocação de recursos escassos na economia (ZEFF, 1999).

O FASB incorporou o objetivo das demonstrações do relatório de Trueblood, o qual era fornecer informações úteis para a tomada de decisões econômicas. Apenas $37 \%$ dos respondentes do memorando de discussão foram capazes de recomendar a adoção desse objetivo; $22 \%$ recomendaram que ele devesse ser rejeitado; $10 \%$ insistiram que necessitava estudos mais aprofundados. Aqueles que discordaram, tomaram a posição de que o fundamento básico das demonstrações financeiras era relatar sobre a administração dos ativos corporativos e que a necessidade informacional dos leitores era de importância secundária (ZEFF, 1999).

Segundo Dopuch e Sunder (1980 apud ZEFF, 1999), os respondentes da pesquisa do memorando de discussão provavelmente pensaram em promover seus próprios interesses em vez de promover os interesses dos leitores em geral. A maioria dos auditores provavelmente 
teria sido educada para acreditar que a contabilidade serve primeiramente a funções administrativas e mostravam certo ceticismo no tocante à função mais ativista na economia da sociedade.

Pouco tempo mais tarde, com os esforços conjuntos do FASB e IASB na busca por comparabilidade e uniformidade, boa parcela dessa estrutura (Conceptual Statements) viria fazer parte da estrutura conceitual do IASB.

\subsection{EVOLUÇÃO HISTÓRICA DO IASC/IASB}

\subsubsection{Contexto Geral da Criação do IASC}

Após a Segunda Guerra Mundial, cada país tinha seus próprios princípios contábeis geralmente aceitos (GAAP, a designação dos EUA), ou prática contábil adequada. Mesmo entre os GAAP em países com ativos mercados de capital próprio em que as empresas cotadas dependiam fortemente de financiamento - os Estados Unidos, Canadá, Reino Unido, Austrália e Nova Zelândia - havia diferenças importantes. Por exemplo, no Reino Unido, Austrália e Nova Zelândia, as empresas podiam reavaliar suas propriedades, fábricas e equipamentos (PPE), incluindo propriedades para investimentos. Nos EUA e o Canadá, principalmente por causa da influência conservadora da SEC (ZEFF, 2007) as empresas aderiram ao custo histórico. Na América do Norte, o LIFO foi amplamente disponível para os inventários, mas no Canadá o seu uso foi limitado a algumas indústrias (SKINNER, 1972, apud ZEFF, 2012). Em 1975, o Normatizador de Padrões da Nova Zelândia emitiu uma norma, SSAP 3 sobre a depreciação, o que exigiu a utilização do método linear (ZEFF, 2012).

Havia um abismo ainda maior entre os GAAP dos países anglo-americanos e dos países do continente europeu e no Japão, onde a tributação de renda levou a prática contábil em que se registrava lucros determinados pela lei do dividendo a ser declarada, e os resultados financeiros poderiam ser manipulados por reservas secretas. Em 1947, a França estabeleceu o Plan comptable général ou National Accounting Plan, uma regulamentação detalhada, codificada da contabilidade das empresas, que foi exportada para a Bélgica e Espanha e, eventualmente, para Portugal, Marrocos, Tunísia, Argélia e Peru (SCHEID; WALTON, 1996, apud ZEFF, 2012). Na maioria dos países em desenvolvimento a divulgação financeira era mínima e havia pouco que pudesse ser chamado GAAP além do que eles poderiam ter herdado de antigos senhores coloniais, como o Reino Unido ou a França. Em suma, a prática 
contábil em todo o mundo era muito diversa (Nobes, 1983 apud ZEFF, 2012) e era significativamente difícil comparar demonstrações financeiras de um país com as de outro.

A década de 1950 iniciou um período de rápido crescimento do comércio internacional e do investimento direto estrangeiro e as empresas começaram a expandir seu alcance além de suas fronteiras. Líderes da profissão contábil viram a internacionalização, como o novo desafio. O AICPA sediou o VIII Congresso Internacional de Contadores em setembro de 1962 em Nova York com o tema Contabilidade e Auditoria na Economia Mundial. Menos de dois anos depois, o AICPA publicou Professional Accounting in 25 Countries, que foi o primeiro grande volume para o levantamento de contabilidade, auditoria e padrões profissionais em todo o mundo (ZEFF; CAMFFERMAN, 2007).

Os anos 1960 foram marcados por fusões e aquisições internacionais frequentes, especialmente corporações americanas assumindo as empresas europeias, e começando a reimplantar suas operações de produção, bem como a sua equipe de gestão internacional. Em abril de 1963, a Business Week publicou uma reportagem especial sobre a nova forma de organização empresarial, chamada de Empresas Multinacionais. Multinacional, a revista escreveu, serve como uma linha de demarcação entre as empresas orientadas internamente com operações internacionais e verdadeiramente corporações orientadas para o mundo. Essa tendência internacionalista aumentou a necessidade de comparar as demonstrações financeiras preparadas em diferentes países (ZEFF, 2012).

Henry A. Benson, sócio sênior da empresa britânica de Cooper Brothers \& Co. (mais tarde Coopers \& Lybrand e que agora faz parte da PricewaterhouseCoopers) e o presidente do Institute of Chartered Accountants na Inglaterra e País de Gales 1966-1967 (ICAEW), lideraram um movimento para atacar o problema de diversas práticas contábeis. Benson, que nasceu e foi criado na África do Sul e, em seguida, imigrou para o Reino Unido, era um homem determinado e engenhoso. Em 1966, ele convenceu o AICPA, o Canadian Institute of Chartered Accountants (CICA), o Institute of Chartered Accountants da Escócia, e o Institute of Chartered Accountants na Irlanda a se juntar ao ICAEW e formar um Grupo de Estudo Internacional de Contadores (AISG). O AISG emitiu uma série de folhetos que - entre outras coisas - comparavam as abordagens de contabilidade e auditoria nos EUA, Canadá e Reino Unido. Entre outras coisas, Benson esperava que uma comparação de abordagem de auditoria nos três países, deveria convencer a profissão contábil no Reino Unido a exigir que o auditor estivesse presente na tomada de inventário, e ele conseguiu nesse esforço (ZEFF; CAMFFERMAN, 2007). Os folhetos do AISG destacaram a diversidade de práticas entre os 
três países e, portanto, a não-comparabilidade das demonstrações financeiras através das fronteiras (ZEFF, 2012).

\subsubsection{Comunidade Econômica Europeia}

Por várias décadas, os países europeus buscaram compartilhar experiências nas áreas econômicas e política para se fortalecerem como bloco único, tendo em vista a crescente supremacia do mercado norte-americano (NIYAMA et al. 1999). O primeiro passo para a constituição da União Europeia data de 25 de julho de 1952, quando foi assinado o tratado de Paris entre Alemanha Ocidental, Bélgica, França, Países Baixos, Itália e Luxemburgo, criando assim a Comunidade Europeia do Carvão e do Aço (Ceca) (MEDEIROS \& CAMPOS, 2009).

Em 1 de janeiro de 1958, seguindo o Tratado de Roma de 1957 foi estabelecida a Comunidade Econômica Europeia (CEE), sendo os seis fundadores membros, França, Republica Federativa da Alemanha, Itália e três países Benelux (Bélgica, Holanda e Luxemburgo) e no decorrer do tempo, se juntaram a eles, em 1973, Reino Unido, Irlanda e Dinamarca; em 1981, Grécia; em 1986, Portugal e Espanha; em 1995, Austrália, Finlândia e Suécia; em 2004, Chipre, Republica Checa, Estônia, Hungria, Látvia, Lituania, Malta, Polônia, Eslováquia e Eslovênia e em 2007, Bulgária e Romênia. Este tratado objetivava, entre outros aspectos, o estabelecimento do movimento livre de pessoas, bens e serviços e capital. Isto envolve a eliminação do imposto aduaneiro, a imposição de tarifas comuns para países terceiros e o estabelecimento de procedimentos para permitir a coordenação de políticas econômicas (NOBES; PARKER, 2010).

Ao consolidar o processo de integração de blocos econômicos, foi assinado em 1991, o Tratado de Maastrich, estabelecendo planos e datas para a implantação da União Europeia, que recentemente resultou no surgimento do euro como moeda de conversão entre os países membros (NIYAMA et al., 1999).

A internacionalização do mercado de capitais, o desenvolvimento de novas praças financeiras e de novos polos de crescimento do mundo, revelou a necessidade de um alinhamento do quadro europeu em matéria de normatização contábil (NIYAMA et al., 1999). As diferenças dos padrões contábeis entre os diversos países eram decorrentes de diferenças culturais, sociais e políticas; situação econômica; sistema legal; nível da profissão contábil; órgãos normatizadores de padrões contábeis, os quais são emitidos através de organismos profissionais, órgãos governamentais ou por ambos; estrutura do mercado financeiro e doutrina da teoria contábil (PAULO, 2002). Essas diferenças motivaram os países europeus, 
através do seu mercado comum, a procurar harmonizar regras do comércio tendo como um dos instrumentos a utilização de informações contábeis (NIYAMA et al., 1999).

Do ponto de vista contábil, nos primeiros anos a UE foi dominada pela França e Alemanha Ocidental. A entrada do Grã Bretanha e Irlanda, em 1973, introduziu as ideias anglo-saxônicas de relatórios financeiros (NOBES; PARKER, 2010).

\subsubsection{As Diretivas: $4^{\mathrm{a}}, 7^{\mathrm{a}}$ e $8^{\mathrm{a}}$}

A UE tentou harmonizar o direito das sociedades e serviços financeiros por meio de dois instrumentos principais: Diretivas, que deveriam ser incorporadas numa das leis dos Estados membros, e Regulamentos, que tornar-se lei em toda a UE, sem a necessidade de passar por legislaturas nacionais (NOBES; PARKER, 2010). As diretivas abrangiam não somente a área contábil, mas também as áreas trabalhista, comercial e outras e não visavam apenas a uniformização das informações contábeis, mas também produzir comparações e equivalência das informações de dados daqueles países (NIYAMA et al., 1999).

Diversas foram as Diretivas e Regulamentos relevantes para a contabilidade corporativa, sendo que as de maior destaque, a $4^{\mathrm{a}}$ diretiva (Quarta lei orientadora - Diretiva 78/660/CCE) e $7^{\text {a }}$ Diretiva (Sétima Lei Orientadora - Diretiva 83/349/CEE) (NOBES; PARKER, 2010; WOLK, 2009; NIYAMA et al., 1999; OLIVEIRA; CARVALHO, 2006). Niyama et al. (1999) acrescenta a Oitava Diretiva (CCE-1984), além das já citadas, destinadas especialmente a proteger interesses dos acionistas e de terceiros.

A Quarta Diretiva Orientadora, de acordo com Saudagaran (2004, apud OLIVEIRA; CARVALHO, 2006) foi importante porque representou a ruptura entre a abordagem legalista da contabilidade presente na maioria dos países da Europa Continental e a aproximação da visão justa e verdadeira que caracteriza a contabilidade do Reino Unido.

A diretiva abrange companhias abertas e fechadas em todos os países da UE. Seus artigos incluem regras de avaliação, formatos de demonstrações financeiras publicadas e exigências de divulgação. Não abrange consolidação, item incluso na Sétima Diretiva. O primeiro esboço da Quarta Diretiva foi publicado em 1971, antes do Reino Unido, Irlanda e Dinamarca entraram na UE em 1973. Este projeto inicial foi fortemente influenciado pela jurisprudência das sociedades alemãs, em particular a Aktiengesetz de 1965. Consequentemente, as regras de avaliação eram conservadoras, formatos foram prescritos em pormenores rígidos e divulgações de notas eram muito limitadas. A influência do Reino Unido e da Irlanda (a partir de sua entrada), na Comissão, no Parlamento e no Groupe d' 
Etudes era tal que um projeto de emenda foi emitido em 1974 e introduziu o conceito de "visão justa e verdadeira". Outra mudança, em 1974, foi a de que alguma flexibilidade de apresentação havia sido introduzida (NOBES; PARKER, 2010, p. 285).

Acrescentam Niyama et al. (1999) que essa Diretiva estabeleceu algumas diretrizes, sendo: a) presunção de que a sociedade continuará suas atividades; b) a não alteração dos critérios de avaliação de um exercício para o outro; c) a prudência; d) a competência; e) a avaliação distinta de elementos de ativos e passivos; e f) a identidade entre balanço de encerramento e balanço de abertura, em relação a exercícios consecutivos. Ainda consagramse os seguintes princípios: i) Imagem fiel do patrimônio; ii) continuidade; iii) materialidade ou importância relativa; iv) não compensação e v) preço de aquisição.

A Sétima Diretiva Orientadora foi publicada em 1983 sob forte influência do modelo anglo-saxônico, isto é, ênfase no controle legal e com o objetivo de consolidar as demonstrações financeiras e dar transparência as informações, além de possibilitar a comparabilidade entre as demonstrações contábeis das empresas no âmbito do bloco (OLIVEIRA; CARVALHO, 2006). Ela destacou um corpo mínimo de princípios: a) a permanência dos métodos de consolidação; b) a eliminação de operações intragrupos ou recíprocas; e c) a apresentação distinta dos interesses minoritários (NIYAMA et al., 1999).

Quanto a Oitava Diretiva, Niyama et al. (1999) ressalta que definiu atribuições, regulamentos e formação de profissionais habilitados ao controle e certificação das demonstrações anuais, não sendo específicos com relação ao campo dos princípios.

\subsubsection{Criação do International Accounting Standards Board - IASB}

A iniciativa de Benson, em 1973 foi ainda mais solene. Após correspondências e reuniões com os líderes dos órgãos de contabilidade de todo o mundo, os esforços de Benson contribuíram para a fundação do International Accounting Standards Committee (IASC). Sua motivação era promover a harmonização internacional das normas contábeis, para diminuir as diferenças de práticas contábeis entre os países. Em 1973, o Reino Unido, juntamente com a Irlanda e a Dinamarca, entraram na Comunidade Económica Europeia (EEC) - hoje conhecida como a União Europeia. Até então, a abordagem da Contabilidade orientada por regras fiscais, utilizada por influência da Alemanha, estava dirigindo o desenvolvimento da Quarta Diretiva do Conselho sobre a contabilidade, o que era para ser incorporado na legislação de todos os Estados membros, após ter sido aprovado pelo Conselho de Ministros. Benson e outros no Reino Unido podem ter acreditado que o IASC poderia promover padrões mais 
alinhados com a abordagem anglo-americana de contabilidade, e assim servir como contrapeso à tendência do desenvolvimento de contabilidade na EEC (ZEFF, 2012).

Pacter (2005) ressalta que uma das vantagens deste método é que ele levou ao que têm sido recentemente descrito como normas baseadas em princípios que exigiram julgamento na aplicação e que continham um número relativamente menor de exceções e regras claras, do que pode ser encontrado nos GAAPs dos EUA e os GAAP de alguns dos outros países fundadores.

A noção de "visão justa e verdadeira" na lei das sociedades do Reino Unido foi exclusiva para a cultura de contabilidade britânica e não tinha equivalente na legislação no continente. Benson também pode ter empurrado para o IASC porque ele não estava satisfeito com a qualidade das normas de contabilidade do Reino Unido e acreditava, que com o impacto sobre as práticas de auditoria no Reino Unido, produzida pelo livreto do AISG sobre os estoques, que as normas de contabilidade do Reino Unido e prática poderia se beneficiar pela junção de seu conselho de contabilidade, unindo em um risco de estabelecimento de padrões de colaboração a nível mundial. Na verdade, mesmo antes do IASC publicar o seu primeiro padrão, Benson convenceu a London Stock Exchange a obrigar as empresas cotadas a divulgar afastamentos (desvios) de normas do IASC, colocando, assim, a pressão sobre o Comitê de Normas de Contabilidade recentemente lançado no Reino Unido e em empresas do Reino Unido quanto a conformidade com o práticas recomendadas nas normas do IASC (ZEFF; CAMFFERMAN, 2007).

O IASC foi à primeira tentativa de definir normas de contabilidade internacional. Em $1973^{5}$, em alguns países havia comitês ou conselhos cujas recomendações influenciaram o curso da prática contábil. Em ordem de cronologia, esses países foram: os EUA, o Reino Unido, Canadá, França, Japão, Austrália e Nova Zelândia. Holanda e África do Sul lançaram recentemente esses órgãos. Os nove países cujos conselhos nacionais de contabilidade foram convidados por Benson a participar do IASC foram, por ordem alfabética: Austrália, Canadá, França, Alemanha, Japão, México, Países Baixos, o Reino Unido e a Irlanda (combinados), e os EUA. Cada país foi representado por uma delegação ${ }^{6}$ de, no máximo, três membros: dois que decidiram sobre o voto da delegação e um observador da equipe. Cada delegação teve um

\footnotetext{
${ }^{5}$ Foi uma coincidência interessante que o IASC passou a existir em 29 de junho de 1973, dois dias antes do Financial Accounting Standards Board (FASB), um órgão independente, que sucedeu o Accounting Principles Board, que foi um comitê do AICPA (ZEFF, 2012).

${ }^{6}$ Os membros das nove delegações foram inicialmente sócios de empresas de auditoria, profissionais de auditoria em nome individual, os executivos dos órgãos nacionais de contabilidade, um acadêmico e um executivo financeiro, todos servindo em uma base a tempo parcial. Nos anos que se seguiram, mais executivos financeiros e usuários nos relatórios econômicos tornaram-se membros (ZEFF, 2012).
} 
voto. Inicialmente, o $\mathrm{AICPA}^{7}$ sozinho patrocinou a delegação norte-americana, mas, eventualmente, o Financial Executives Institute e o Institute of Management Accountants tornaram-se co-patrocinadores (ZEFF, 2012).

Acrescenta Pacter (2005) que a criação do IASC ocorreu por ocasião do $10^{\circ}$ Congresso Mundial de Contadores em Sydney, quando os órgãos de classe de contabilidade em nove países concordaram com a sua criação. Todos eles se comprometeram com uma meta muito alta, envidando seus melhores esforços para a adoção das Normas Internacionais de Contabilidade (IAS) em substituição dos seus princípios contábeis geralmente aceitos nacionais $^{8}$.

Dessa forma, foi criado o IASC em 1973 por organizações de profissionais de contabilidade, como um organismo de normalização independente, do setor privado (CHOI; MEEK, 2011), por ocasião do Congresso Internacional de Contadores em Melbourne (Austrália), sendo fundado pelos seguintes países: Austrália, Canadá, França, Alemanha, Japão, México, Holanda, Grã-Bretanha, Irlanda e Estados Unidos da América (NIYAMA, 2010, PAULO, 2002). Outros países foram se associando gradativamente, entre os quais o Brasil, representado pelo Conselho Federal de Contabilidade (CFC) e pelo Instituto dos Auditores Independentes do Brasil (IBRACON) e que hoje reúne mais de 140 entidades de todo o mundo (PAULO, 2002).

O objetivo principal do IASC foi à emissão de normas básicas, chamadas de International Accounting Standard (IAS), que, esperava-se, levaria a uma harmonização das normas de contabilidade em todo o mundo (ZEFF, 2012). De forma específica, os objetivos definidos no acordo que precede a carta constitutiva eram os seguintes: 1) elaborar e publicar, notoriamente, normas contábeis internacionais, que deverão ser observadas nos relatórios contábeis e 2) promover a aceitação e adoção prática de tais normas em escala mundial (MULLER, 1999). O Conselho elegeu Henry Benson como presidente em sua primeira reunião (ZEFF, 2012).

Os orgãos de contabilidade nacionais assinaram um acordo, afirmando que eles usariam seus melhores esforços para promover a utilização das normas do IASC em seus países (ZEFF; CAMFFERMAN, 2007). A maioria (três quartos) foi necessária para aprovar exposure drafts e os padrões finais. Como os membros de um número de países defenderam a

\footnotetext{
${ }^{7}$ O AICPA foi um dos cinco patrocinadores da Financial Accounting Foundation, que supervisionou o FASB, mas era agora também o patrocinador da delegação dos EUA no tocante ao IASC, que alguns poderiam ter visto como um concorrente do FASB (ZEFF, 2012).

${ }^{8}$ Vinte e oito anos depois, em abril de 2001, quando o IASC passou o bastão para o IASB, cada um dos nove países ainda tinha o seu próprio GAAP nacional. E em apenas um deles permitia que as empresas nacionais utilizasse as IASs.
} 
legalidade das práticas contábeis utilizadas em seus próprios países, e também porque algumas delegações dos países preferiram a flexibilidade de ter tratamentos contábeis opcionais ou métodos, algumas normas foram emitidas com escolhas livres. A votação em cada projeto de exposição e padrão não foi relatada e opiniões divergentes existentes foram publicadas. O pessoal técnico frequentemente consultava os padrões dos EUA e do Reino Unido, entre outros, nas primeiras elaborações (ZEFF, 2012).

As receitas e os custos da sede em Londres foram suportados pelo ICAEW. Dentro de um ano, os órgãos responsáveis de outros países começaram a assinar como membros associados, assumindo o compromisso de que eles também usariam seus melhores esforços para promover a aceitação das normas do Conselho em seus países e também concordando em contribuir com os custos do IASC $^{9}$ (ZEFF; CAMFFERMAN, 2007).

No ano seguinte à sua criação o IASC publicou o primeiro Exposure Draft, que, em 1975, transformou-se na IAS 1, sob o título Disclosure of Accounting Policies (PAULO, 2002). Nesse mesmo ano foi publicado a IAS 2 - Avaliação e Apresentação de Estoques no Contexto do Sistema de Custo Histórico, resultando nos dois primeiros padrões (IAS) em versão final publicados.

Em 1987 o International Organization of Securities Commissions (IOSCO) se une ao Grupo Consultivo do IASC, apoiando o Projeto de Comparabilidade, e somente em 1988 o FASB se une ao Grupo Consultivo, apenas como observador, sendo que em 1991 declara que planeja apoiar as Normas Internacionais de Contabilidade (PAULO, 2002). Em 1995, a UE reconheceu a necessidade de uma maior harmonização da informação financeira no âmbito da EU, que deveria ir além do nível alcançado pelas Diretivas Europeias de Contabilidade e, assim, a UE manifestou o seu apoio para com as IAS (CUIJPERS; BUIJINK, MAIJOOR, 2002).

Em 1989, foi emitida a Estrutura Conceitual do IASB $^{10}$ e foi dita como fortemente reminiscente do trabalho do FASB - antes de 1989 o FASB foi o único normatizador nacional a ter completado um quadro normativo. A lista de características qualitativas seguia de perto

\footnotetext{
${ }^{9}$ Desde o início, a Comissão Europeia, o braço administrativo da EEC, deu pouca atenção ao IASC. Talvez acreditasse que um organismo do setor privado iria assistir apenas aos interesses particulares de seus membros e não ao interesse público que uma agência do governo, tais como a Comissão pretendia servir. O FASB, por sua vez, também deu pouca atenção ao IASC e preferiu se concentrar na melhoria dos US GAAPs. Essa postura foi mudada no final da década de 1980.

${ }^{10}$ Era objetivo declarado pelo IASC (na Estrutura Conceitual) das demonstrações financeiras (não dos relatórios financeiros) é fornecer informações sobre a posição financeira, desempenho e alterações na posição financeira de uma entidade, que seja útil a uma vasta gama de usuários na tomada de decisões econômicas. Estas decisões econômicas exigem uma avaliação da capacidade da entidade em gerar caixa e equivalentes de caixa e da tempestividade e certeza da sua geração. Embora tais demonstrações financeiras satisfaçam as necessidades comuns da maioria dos usuários, elas não fornecem todas as informações que os usuários podem precisar na tomada de decisões econômicas, uma vez que grande parte retratam os efeitos financeiros de acontecimentos passados e não proporcionam necessariamente informação não financeira.
} 
os quadros anteriores, com poucas mudanças. Relevância e Confiabilidade foram duas das quatro principais características qualitativas. A Prudência ${ }^{11}$ apareceu como uma sub-qualidade da Confiabilidade (ZEFF, 2013).

Foram listados como usuários das demonstrações financeiras - na Estrutura Conceitual os investidores, empregados, credores, fornecedores e outros credores comerciais, clientes, governos e suas agências e o público em geral. Presume-se que, não obstante o número e a variedade de usuários, a maior parte de suas necessidades era comum a todos. Como os investidores são os fornecedores de capital de risco para a entidade, o fornecimento de demonstrações contábeis que atendam às suas necessidades também iria atender a maioria das necessidades de outros usuários que as demonstrações financeiras podem satisfazer (ZEFF, 2013).

O Congresso americano exige, em 1996, um conjunto de padrões de alta qualidade de princípios contábeis internacionais geralmente aceitos. Em 1998, novas leis nacionais são emitidas na Bélgica, França, Alemanha e Itália, as quais permitem as grandes companhias usarem domesticamente as IASs (PAULO, 2002).

Em 1999, quando o IASC foi se reestruturando, a SEC insistiu que o conhecimento técnico seria o único critério para a participação no Conselho. Muitos europeus, incluindo a União Europeia, apoiava a representação geográfica como critério principal e argumentava que os países que se comprometeram com a implementação das normas do IASC deveriam ter voz dominante e votar em sua formulação. Depois de uma dura batalha, a opinião da SEC prevaleceu. Assim, a Constituição da International Accounting Standard Committee Foundation (IASCF) inicial estipulava que a qualificação mais importante para filiação no IASB seria o conhecimento técnico. A SEC ressaltou que preferia um conselho de sete membros, ao passo que algumas pessoas de destaque na Europa Continental queriam um conselho de 21 membros. Um acordo foi alcançado com um Conselho de 14 membros (ZEFF, 2008).

Em 2001 o IASC foi reestruturado, sendo que até aquele momento, haviam sido emitidas 41 IAS e uma Estrutura Conceitual para Elaboração e Apresentação das Demonstrações Financeiras (CHOI; MEEK, 2011). A partir da reestruturação, o novo órgão foi denominado International Accounting Standard Board (IASB) onde as novas normas emitidas seriam chamadas International Financial Reporting Standards (IFRS) e as antigas (IAS), recepcionadas pelo novo órgão.

\footnotetext{
${ }^{11}$ O IASC definiu a prudência como a inclusão de um grau de precaução no exercício dos juízos necessários ao fazer as estimativas necessárias em condições de incerteza, de forma que os ativos ou receitas não sejam superestimados e passivos ou despesas não sejam subestimados. A prudência não permite o eufemismo (intencional) de ativos ou receitas ou sobreavaliação de passivos ou despesas, pois isso violaria a neutralidade, o que era outra sub-qualidade da confiabilidade.
} 
A partir daí, o IASB visava à convergência das normas contábeis e teve como objetivos: a) desenvolver, no interesse público, um único conjunto de normas contábeis globais de alta qualidade, inteligíveis, exequíveis, que exijam informações de alta qualidade, transparentes e comparáveis nas demonstrações contábeis e em outros relatórios financeiros, para ajudar os participantes do mercado de capital e outros usuários, em todo o mundo, a tomar decisões econômicas; b) promover o uso e a aplicação rigorosa dessas normas; e c) promover a convergência entre as normas contábeis locais e as Normas Internacionais de Contabilidade de alta qualidade (NIYAMA, 2010; CHOI; MEEK, 2011; PACTER, 2005).

Em fevereiro de 2001, a UE propôs que fosse exigido de todas as empresas domiciliadas na EU e cotadas em bolsas de valores no seu seio, que elas preparassem suas demonstrações financeiras de acordo com a IAS até 2005. O Parlamento Europeu e o Conselho adotaram o regulamento elaborado pela Comissão Europeia em Maio de 2002 (CUIJPERS; BUIJINK; MAIJOOR, 2005). Naquele ano, eles aprovaram e adotaram o regulamento, exigindo que todas as empresas da EU, cotadas no mercado regulamentado deveriam seguir IFRS em suas demonstrações financeiras consolidadas, a partir de 2005. Os Estados-Membros eram livres para alargar este requisito para todas as empresas, e não apenas as listadas, incluindo as demonstrações financeiras de empresas individuais (CHOI; MEEK, 2011; CUIJPERS; BUIJINK; MAIJOOR, 2002).

A Bolsa de Valores de Nova York também aprovou medida semelhante, permitindo que empresas estrangeiras, interessadas em ter suas ações negociadas naquela Bolsa, apresentem demonstrações contábeis elaboradas com base nas normas internacionais de contabilidade do IASB, a partir de 2005 (NIYAMA, 2010).

Muitas empresas tinham adotado voluntariamente as IFRS para preparar relatórios financeiros desde o final da década de 1990. Estudos prévios documentaram que a adoção voluntária das IFRSs beneficiavam as empresas de diversas formas: possibilitavam redução do custo de capital; forneciam transparência e comparabilidade dos relatórios financeiros; reduziam a assimetria da informação entre os acionistas e gestores, permitindo uma alocação mais eficiente de investimentos em todo o mundo (CHEN et al., 2010).

Diversos estudos apontaram que a adoção das normas do IASB trouxe melhoria na qualidade da informação contábil (ASHBAUGH; PINCUS, 2001; YOON, 2007; BARTH; LANDSMAN; LANG, 2008; CHRISTENSEN; LEE; WALKER, 2008; PAANANEN; LIN, 2009; CHEN et al., 2010; IATRIDIS, 2010). Uma possível explicação para esses resultados é a qualidade superior das normas do IASB em relação ao conjunto de normas locais de 
diversos países, ao tratar de diversas situações não contempladas nas normas locais (KLANN, BEUREN, 2010).

Em setembro de 2010, como parte do projeto de elaboração de uma Estrutura Conceitual comum, o IASB e o FASB emitiram o capítulo 1, The Objetive of General Purpose Financial Reporting, e o capítulo 3, Qualitative Characteristics of Useful Financial Information. O FASB intitulou seu documento, Statement of Financial Accounting Concepts $\mathrm{n}^{\circ} 8$ (SFAC 8), Conceptual Framework for Financial Reporting, e o documento do IASB foi intitulado The Conceptual Framework for Financial Reporting 2010. Ambos os Conselhos tinham emitido um discussion paper em julho de 2006 e um exposure draft em maio de 2008 - nenhum deles havia realizado uma audiência pública (ZEFF, 2013).

Na listagem e discussão das características qualitativas, no capítulo 3, a confiabilidade, como usada na SFAC $\mathrm{N}^{\mathrm{o}} 2$ e na Estrutura Conceitual do IASC, foi abandonada e a representação fiel foi elevada para tomar seu lugar como uma das duas características qualitativas fundamentais (juntamente com relevância) no caso da Estrutura Conceitual do IASB e de uma das quatro principais características qualitativas no caso do FASB ${ }^{12}$ (ZEFF, 2013). O FASB e o IASB acreditavam que a confiabilidade era muito frequentemente confundida com precisão, e se confiabilidade foi assim definida para compensar relevância, o aumento do uso de mensuração do valor justo poderia ser impedida (JOHNSON, 2005).

Ao discutir a manutenção do capital, Flower (2004) levanta o princípio da prudência. Prudência teve uma influência muito grande sobre a prática dos contadores de alguns países europeus. Na verdade, pode-se caracterizá-la como princípio orientador na Alemanha e em países com estreitos laços culturais e econômicos para com a Alemanha, como a Áustria e a Suíça. Um estudo realizado pela FEE (1997 apud ZEFF, 2013) também mencionou a República Checa e Luxemburgo como estando na mesma categoria que a Alemanha em relação a importância da prudência. O princípio da prudência foi estipulado na Quarta Diretiva relativa ao direito da CEE, que dizia entre outras coisas: deve-se ter em conta os riscos previsíveis e as perdas potenciais (FEE 1997 apud ZEFF, 2013). Mesmo com a adoção das IFRS pelas empresas cotadas em suas demonstrações consolidadas a partir de 2005,

\footnotetext{
12 Embora o FASB e IASB reconhecessem que a prudência, ou conservadorismo, tinha sido um aspecto da confiabilidade no quadro do IASC, eles não consideram que seja um aspecto da representação fiel, pois seria incompatível com a neutralidade e poderia levar a viés. Por isso, a prudência foi retirada do conjunto de características qualitativas. O Presidente do IASB - Hans Hoogervorst - disse em um discurso em setembro de 2012 que uma das razões para o abandono da prudência, era a convergência com os US GAAP, que não tinham uma definição de Prudência. Mais geralmente, muitos sentiram que na prática o conceito de prudência foi muitas vezes utilizado como pretexto para o Cookie-Jar Accounting.
} 
contadores, provavelmente, ainda exibem uma atitude conservadora (prudente), utilizada antes da adoção das IFRS (ZEFF, 2013).

Os estados membros da UE diferiam consideravelmente na ênfase dada a prudência. Por um lado, a Alemanha dava grande peso ao princípio da prudência, considerando-o como a base sobre a qual toda a estrutura de relatório financeiro é construída. Por outro lado, a GrãBretanha colocava mais ênfase na "visão justa e verdadeira". De uma perspectiva histórica, o mais antigo objetivo estabelecido na preparação das demonstrações financeiras na Alemanha, o que também se reflete nas diretivas da União Europeia, é a proteção dos credores. No interesse da proteção de credores uma apresentação completa de todos os ativos e passivos e uma avaliação conservadora são necessários. A Alemanha deu grande peso ao princípio da prudência, considerando-a como a base sobre a qual toda a estrutura dos relatórios financeiros é construída (FLOWER, 2004).

Em 2010, IASB e FASB suspenderam o trabalho conjunto na estrutura conceitual, a fim de se concentrar em outros projetos em suas agendas. Em 2012, o IASB realizou uma consulta pública sobre a sua agenda. Muitos entrevistados consultados identificaram a Estrutura Conceitual como projeto prioritário para o IASB. Consequentemente, o IASB reiniciou seu projeto, que não está sendo realizado em conjunto com o FASB. Comentários recebidos da Consulta de Agenda 2011 reforçaram a importância de priorizá-lo (IASB, $\mathrm{DP} / 2013 / 1)$.

\subsection{CONTRIBUIÇÕES DE PESQUISAS ANTERIORES}

\subsubsection{Nacionais}

Dentre os estudos que abordam a Evolução dos Princípios Contábeis, Estrutura Conceitual da Contabilidade e Análise de Conteúdo, no tocante às pesquisas nacionais, estão os de Niyama et al. (1999), Paulo (2002), Oliveira (2003), Oliveira e Carvalho (2006) e Matos (2013). A pesquisa elaborada por Niyama et al. (1999) teve por finalidade apresentar, discutir e comparar os princípios contábeis adotados pelo Brasil e os adotados pelos países europeus maior parte deles integrantes da União Européia - em especial, França, Grã-Bretanha, Portugal, Itália, Espanha e Alemanha. Eles destacaram a trajetória histórica da constituição do bloco econômico europeu e evidenciaram as principais diretivas que influenciaram a área contábil, a saber, $4^{\mathrm{a}}, 7^{\mathrm{a}}$ e $8^{\mathrm{a}}$ Diretivas. 
Paulo (2002) realizou um estudo comparativo entre a Estrutura Conceitual emitida pelo IASB, a Estrutura Conceitual editada através das Statements of Financial Accounting Concepts - SFACs, emitidas pelo FASB, e a Estrutura Conceitual Básica de Contabilidade aprovada pela Comissão de Valores Mobiliários - CVM, verificando suas semelhanças e diferenças. Oliveira (2003) analisou a evolução da terminologia princípio contábil, à luz das mudanças e evoluções no cenário econômico-financeiro norte-americano. A pesquisa teve como escopo a Escola norte-americana de contabilidade. Foi abordada, a influência do Feudalismo e do Mercantilismo na concepção econômica europeia; a importância da Revolução Industrial no início da normatização contábil e o papel da Inglaterra na formação da Escola norte-americana e o desenvolvimento do cenário da sociedade americana, enfocando a contribuição na busca da construção de um referencial teórico.

Oliveira e Carvalho (2006) investigaram as implicações sobre as práticas contábeis dos países da União Europeia - em particular a França - após a adesão aos preceitos estabelecidos na Quarta e Sétima Diretivas, as quais denotam maior impacto na contabilidade nacional de cada país do bloco.

No que tange à análise de conteúdo, Matos (2013) objetivou analisar a opinião dos usuários da contabilidade sobre os critérios de reconhecimento, mensuração e apresentação propostos no ED/2010/9 - Leases. O autor lançou mão da técnica da análise de conteúdo, com a categorização das opiniões dos usuários, emitidas por meio das comment letters - 262 no total - para a compreensão de suas opiniões e reações quanto às mudanças propostas, demonstradas de forma descritiva.

\subsubsection{Internacionais}

Em âmbito internacional, El-Essely (1987) empenhou-se em desenvolver um modelo de aplicação geral para a identificação e gestão de problemas contábeis nos países em desenvolvimento, dando-lhes sugestões para melhorar as práticas. Uma das ferramentas básicas do seu modelo utiliza as três dimensões das características da estrutura conceitual na análise de problemas de contabilidade. No processo de construção do modelo, as possibilidades de aplicação de alguns modelos que têm sido utilizados em ciências físicas foram discutidos com o objetivo de adaptar ou adotá-las na identificação e gestão de alguns problemas em ciências sociais.

Foram constatadas relações positivas: a) entre a satisfação dos entrevistados com a utilidade da informação fornecida para o planejamento de investimento nacional (principal 
objetivo) e sua satisfação - sua utilidade; b) na visão dos entrevistados do ranking da importância das várias demonstrações financeiras para servir o propósito de planejamento de investimentos nacional e seus pontos de vista deste ranking para servir de controle de investimento nacional; e, c) entre os pontos de vista dos entrevistados, do grau de influência das diferentes demonstrações financeiras em planejamento de investimentos nacionais e seus pontos de vista da influência das demonstrações sobre o controle nacional de investimento (EL-ESSELY, 1987).

A Tese de Gore (1989) analisa os vários aspectos das origens, o desenvolvimento e o legado do projeto de Estrutura Conceitual do FASB, sendo, de longe o mais extenso, mais caro e, sem dúvida, o mais importante formalmente constituído na história da contabilidade. Tendo em vista que foi amplamente sugerido que o projeto foi um fracasso, a investigação se propõe a avaliar a veracidade desses fatos, mas também com a intenção de descobrir se lições podem ser aprendidas a partir da experiência do FASB, de forma que se permitam futuros esforços para evitar tais críticas.

Acrescenta-se que até a data da pesquisa o Reino Unido vinha seguindo um caminho semelhante ao dos $\mathrm{EUA}^{13}$. O autor sugeriu que se deveria tomar nota da experiência dos Estados Unidos e fazer melhor do que eles. Explicação sobre o caminho de desenvolvimento do projeto é procurado por uso de teorias da regulação, tanto econômicas quanto políticas na origem. Apesar de se verificar que os eventos reais estão de acordo com as previsões de algumas dessas teorias, concluiu-se que a causalidade não pode ser provada: essas teorias podem ser mais bem utilizadas para concentrar a atenção em questões de particular importância. A influência da Estrutura Conceitual do FASB é examinada, tanto dentro como fora dos EUA. Grande influência é detectada fora dos EUA, em outras Estruturas Conceituais sendo desenvolvido na época, o que de fato aconteceu inclusive com a Estrutura Conceitual do IASB (GORE, 1989).

Hines (1991) aborda as falhas funcionais da Estrutura Conceitual do FASB. Ele sugere que a razão para os problemas encontrados pelo FASB em seu projeto da Conceptual Framework (CF), e aquelas encontradas em outros projetos da $\mathrm{CF}$, é que a ela é elaborada em torno de uma concepção altamente problemática da relação entre a contabilidade financeira e a realidade econômica. Em vez de adotar a visão funcionalista convencional de outros projetos, adotou uma perspectiva construcionista social em Estrutura Conceitual. Estruturas Conceituais presumem legitimar e reproduzir a suposição de um mundo objetivo e, como tal,

\footnotetext{
${ }^{13}$ Os autores salientam que uma Estrutura Conceitual poderia surgir a partir da experiência dos EUA, fato que se concretizou no mesmo ano da pesquisa.
} 
elas desempenham um papel na constituição do mundo social. Além disso, pode fornecer legitimidade social para a profissão contábil. O ensaio se baseia na antropologia para mostrar que essa suposição de uma realidade social concreta e objetiva é um produto de raciocínio diário, como a dos membros do FASB. À luz da discussão, sugere-se que uma postura socialmente desejável para os pesquisadores é ver a verdade como o que é melhor para acreditar, e não como a representação fiel da realidade.

Nussbaumer (1992) afirma que após muito tempo - mais de uma década - e dinheiro que foi gasto no desenvolvimento da Estrutura Conceitual do FASB, ainda não há acordo sobre sua utilidade. Observando as demonstrações individuais e questões contábeis específicas, fica evidente que a Estrutura Conceitual forneceu alguns de seus benefícios prometidos e tem sido bem sucedida em algumas áreas. No entanto, o autor enfatiza que esses sucessos têm sido limitados a questões que não eram controversas, e não tem sido evidente nas questões mais complexas que devem ser abordadas pelo FASB. As falhas da Estrutura Conceitual sobre questões controversas específicas podem ser esperadas, dada à natureza ampla da Estrutura Conceitual, visto que ela não se destinava a ser a solução final para todos os problemas de contabilidade. O seu papel é fornecer orientação para o FASB e não resolver todas as questões.

Nussbaumer (1992) conclui que a Estrutura Conceitual (vigente na data da pesquisa) tinha sido útil para o FASB por algumas medidas. No entanto, este quadro conceitual poderia ser mais útil se fosse dado prioridade novamente. Além disso, as áreas de difícil reconhecimento e mensuração precisam ser tratadas de uma maneira que irá resultar em informações significativas para a orientação tanto do FASB, quanto de outros agentes.

O estudo de Bence (1996) teve por objetivo identificar e analisar os objetivos e as necessidades de informação dos participantes do processo de informação financeira e, portanto, iluminar as discussões sobre marcos conceituais. O estudo baseia-se em uma sociedade anônima e examina os objetivos e as necessidades de informação dos principais participantes do mercado de capitais no processo de informação financeira: produtores, analistas de investimentos, investidores institucionais e acionistas privados. Usando o estudo de caso e as referências da extensa literatura, o autor argumenta que os participantes têm objetivos conflitantes. Marcos conceituais não conseguem identificar explicitamente os objetivos e conflitos entre os participantes e são, portanto, deficientes em explicar os relatórios financeiros. $\mathrm{O}$ autor argumenta que a contabilidade financeira só pode ser plenamente compreendida se organismos de normalização analisar e codificar os conflitos entre os participantes em um modelo político do processo de informação financeira. Se as 
estruturas conceituais existem com o objetivo de melhorar as práticas de relatório financeiro, deve-se incluir um exame dos objetivos dos participantes como parte de um modelo político do processo de informação financeira.

Xiao e Pan (1997) mostram que contraditoriamente com algumas teorias já existentes, o governo chinês tem desenvolvido normas de contabilidade com base em uma estrutura conceitual intitulada Accounting Standards for Business Enterprises (ASBE). O ensaio analisou as potenciais vantagens e desvantagens da abordagem chinesa e as razões para adotar essa abordagem, e investigou os pontos fortes e fracos do ASBE como Conceptual Framework (CF) e as características das normas contábeis específicas emitidas até então. A CF pode ser construída sobre as normas de contabilidade, o que por sua vez pode ser desenvolvidas com base em uma CF. Sua formulação e do desenvolvimento de padrões irão beneficiar um ao outro, por que não é possível desenvolver tanto uma $\mathrm{CF}$ perfeita ou um conjunto de normas de contabilidade perfeitas. Pode-se esperar que ambas fossem revistas e alteradas de tempos em tempos. Isto também significa que a definição de normas de contabilidade é evolutiva, na prática, ainda que alguns critiquem a abordagem evolutiva.

A adopção de uma abordagem baseada na Conceptual Framework pelos organismos de normatização contábil chinesa foi determinada ou afetada por uma série de fatores. A principal delas parece ser a necessidade urgente de uma revisão dos sistemas de contabilidade uniformes. Adicionalmente, a CF pode desempenhar um papel importante na definição de normas de contabilidade, mesmo quando tanto o poder e a responsabilidade sobre a definição de normas de contabilidade estão nas mãos do governo (XIÃO E PAN, 1997).

Dessa forma os autores finalizam enfatizando que uma Conceptual Framework pode ser usada para cumprir diferentes fins, dependendo da orientação em uso. Se o objetivo é estabelecer novos padrões, uma CF mais prescritiva é desejável. Em caso de descritiva pode ajudar a padronizar ou harmonizar as práticas contábeis existentes e aumentar a consciência da prática existente, as partes relevantes. Se constitutiva, é necessária para a transformação dos sistemas contábeis uniformes aos padrões contábeis exigidos por uma economia orientada para o mercado. Parece que o ASBE desempenha um papel importante nos dois últimos aspectos. Em contraste, embora uma referência importante, que está longe de ser suficiente para a prescrição de normas específicas e, portanto, algumas normas específicas são derivadas de outras fontes, que não ASBE.

A tese de Solomon (1998) objetivou desenvolver um caminho a seguir pelos relatórios ambientais das empresas na Grã-Bretanha, dada à ausência de qualquer nova legislação que exige das empresas a divulgação ambiental obrigatória, tendo como objetivo principal iniciar 
o processo de tornar a estrutura de relatório implícito, explícito, investigando as necessidades dos usuários e identificando o nível de consenso entre todas as partes envolvidas. A abordagem envolve a investigação de eventuais ligações entre o relatório financeiro e ambiental, trabalhando assim, dentro do status quo. Essa tese investiga empiricamente as possíveis ligações entre a estrutura conceitual para relatórios financeiros corporativos e uma estrutura conceitual (desenvolvido no âmbito da tese) para a comunicação ambiental corporativa baseada no consenso entre normativa, parte interessada, e grupos de amostras de empresa.

Os resultados indicam que os entrevistados estão de acordo que a conformidade dos relatórios é útil. Esta opinião é corroborada pelos resultados positivos em que conformidade com a legislação é sugerida. Os dados também sugerem que a divulgação de uma base financeira, quantitativa e/ou qualitativa, para uma variedade de itens, seria útil. Há também suporte para um quadro global de relatórios ambientais e financeiros, com um acordo sobre os elementos, características qualitativas e objetivos. Finalmente, há um grau visível de consenso entre as opiniões expressas pelo grupo normativo e os do grupo interessado, permitindo a conclusão da segunda fase de uma estrutura conceitual para elaboração de relatórios ambientais das empresas (SOLOMON, 1998).

Zeff (1999) resume a história da Estrutura Conceitual dos EUA, a partir da década de 1920 até a emissão do arcabouço teórico do FASB (SFACs). Ele evidencia os principais documentos emitidos nesse período e as suas contribuições e críticas recebidas, bem como a participação das entidades de classe e dos principais pesquisadores no transcorrer desses anos. As evidências apontam que diversos fatores influenciaram na trajetória e na emissão da Estrutura Conceitual do FASB, tais como: políticas da SEC; forte pressão do mercado de capitais; quebra da NYSE; busca por Princípios Contábeis; necessidade de harmonização das práticas contábeis; disputas entre entidades de classe (AIA x AAA) para emissão de Princípios Contábeis.

Bradbury (2003) objetivou documentar interações entre a contabilização dos instrumentos financeiros e Estrutura Conceitual - delineando questões, não necessariamente resolvendo-as. O autor descreve alguns dos problemas enfrentados pelos organismos de normatização na elaboração de orientações sobre a contabilização de instrumentos financeiros e as implicações destas questões para a Estrutura Conceitual. Um conjunto de usuários do CF são os Normatizadores. Recentes documentos sobre instrumentos financeiros, como o discussion paper (DP) de 1997 - Accounting for Financial Assets and Financial Liabilities, e o Financial Instruments Joint Working Group of standard setters (JWG) 2000, foram 
baseados na $\mathrm{CF}$. $\mathrm{O}$ artigo destacou as áreas onde a prática entra em conflitos com as orientações da CF.

Outro conjunto de usuários da CF são os preparadores de demonstrações financeiras. Compreender a CF é essencial para os preparadores se desejam influenciar organismos de normatização sobre questões contábeis. Infelizmente, algumas respostas às declarações de instrumentos financeiros indicam que os conceitos subjacentes (tais como a confiabilidade) não são bem compreendidos. Mais importante ainda, os constituintes se baseiam em conceitos que não estão elencados na CF. As mais significativas dessas crenças se relacionam com o papel de intenção da Administração, a consistência com as práticas de gestão interna, o papel do lucro na determinação de dividendos e tributação (BRADBURY, 2003).

A tese elaborada por Dennis (2006) objetivou realizar uma investigação filosófica da Estrutura Conceitual da Contabilidade. Pouca atenção havia sido dada ao papel e status do que poderia ser chamado de considerações conceituais em relatórios financeiros. Em particular, ele argumenta que houve uma falha em fazer inquéritos adequados para a natureza do conceito de uma Estrutura Conceitual da contabilidade. Um dos objetivos desse trabalho foi preencher essa lacuna. A tese argumenta que a falta de acordo sobre o que é uma Conceptual Framework é resultado de uma incapacidade de compreender a natureza de "princípios" de contabilidade ou relatórios financeiros. Estruturas Conceituais foram caracterizadas na literatura como o resultado de uma busca por princípios de contabilidade ou de relatório financeiro.

Dennis (2006) afirma que no final de uma década de pesquisa de princípios, Littleton comentou que a palavra princípios, sem dúvida, havia sido sobrecarregada na literatura contábil, sendo amplamente utilizada pelos profissionais de contabilidade e escritores acadêmicos com pouca discriminação. Cada livro normalmente contém uma mistura de axiomas, convenções, generalizações, métodos, regras, postulados, práticas, procedimentos, princípios e normas. Estes termos não podem ser sinônimos e poucos esforços têm sido dispendidos para mostrar que eles não são, embora a necessidade de separação torne-se mais evidente à medida que o tempo passa. Porque é que falta acordo sobre a ideia ou o conceito da Estrutura Conceitual que seja importante? Conceitos nos levam a fazer investigações; é a expressão do nosso interesse, e dirigem nosso interesse. Conceitos nos ajudam a compreender as coisas, correspondem a uma forma particular de lidar com as situações.

Dennis (2006) complementa que a Conceptual Framework surgiu a partir da busca por princípios contábeis e por isso esta investigação examina o conceito relacionado de princípio, bem como o conceito de uma CF. Diferentes concepções de princípios são identificadas e 
argumenta-se que a falta de explicar ou diferenciar esses conceitos resultou em confusão sobre as ideias de uma Conceptual Framework concebida como uma declaração de princípios. Duas concepções importantes destacam-se: princípios podem ser entendidos como razões para regras ou como as regras de certo tipo. Argumenta-se que as falhas em distinguir diferentes tipos de princípios e de raciocínio são evidentes no atual debate sobre Normas baseadas em Princípios versus baseadas em regras e prejudicam a compreensão das questões envolvidas. Desde princípios, concebido como regras, incluem regras de reconhecimento e de mensuração. A natureza dessas regras e das atividades conexas de mensuração e reconhecimento é considerada. A tese conclui contrastando a natureza de princípios e Estrutura Conceitual existentes com uma visão alternativa de que eles poderiam estar usando as ideias nela (tese) desenvolvidas. Identifica algumas questões sobre a concepção de uma Estrutura Conceitual que aqueles que formulam esses quadros precisam considerar antes de qualquer revisão.

O ensaio escrito por Whittington (2008) analisa diversas questões polêmicas decorrentes do projeto conjunto do IASB e FASB para desenvolver uma Estrutura Conceitual comum para os padrões de relatórios financeiros. Ele discute suas possíveis implicações para a mensuração, em particular, para o uso do Valor Justo como base de mensuração preferida. O Valor Justo assume que os mercados são relativamente perfeitos e completos e que, em tal contexto, os relatórios financeiros devem atender às necessidades dos investidores e credores, relatando valores de mercado derivados de preços correntes. A visão alternativa assume que os mercados são relativamente imperfeitos e incompletos e que, em tal contexto de mercado, relatórios financeiros devem também cumprir os requisitos de monitorização dos atuais acionistas, relatando transações e eventos passados, usando medidas específicas da entidade que reflitam as oportunidades realmente disponíveis para a entidade que relata. Ele discute o suporte teórico para os dois pontos de vista. $\mathrm{O}$ autor evidencia que em um cenário realista do mercado, a busca de um método de mensuração universal pode ser infrutífera e uma abordagem mais adequada poderia ser definir um objetivo claro de mensuração e selecionar o método que melhor atende a esse. 


\section{METODOLOGIA}

\subsection{CRITÉRIOS DE PESQUISA}

Walliman (2001) comenta que, uma vez que o problema de pesquisa foi formulado, deve tornar-se evidente que tipo de dados serão estudados e também que tipo de análise será adequada para analisar os dados. Walliman (2001) ressalta que os diferentes tipos de perguntas que instigam a pesquisa requerem abordagens de pesquisa que se distinguem pela sua formação teórica e metodológica.

Para efeito dessa pesquisa foram escolhidos os critérios que melhor se adequam ao problema de pesquisa proposto, explicados nos itens que se seguem, a fim de que os objetivos sejam alcançados. Esta pesquisa é caracterizada como descritiva com abordagem qualitativa e será realizada por meio de pesquisa documental através da técnica de análise de conteúdo.

\subsubsection{Pesquisa Descritiva}

Segundo Walliman (2001), em vez de examinar registro ou artefatos, a pesquisa descritiva se baseia na observação como um meio de coleta de dados. Ela tenta examinar situações, a fim de estabelecer o que é a norma, ou seja, o que pode ser previsto para acontecer novamente sob as mesmas circunstâncias. 'Observação' pode assumir muitas formas. Dependendo do tipo de informação procurada, as pessoas podem ser entrevistadas, questionários distribuídos, registros visuais feitos, até mesmo sons e cheiros gravados. O ponto importante é que as observações são anotadas ou gravadas, de alguma forma, de modo que elas podem ser subsequentemente analisadas. É importante que os dados recolhidos sejam organizados e apresentados de uma forma clara e sistemática, de modo que a análise possa resultar em conclusões válidas e precisas.

De acordo com Kothari (2004), a pesquisa descritiva inclui levantamentos e investigações de diferentes tipos de averiguação. O seu objetivo principal é a descrição do estado de coisas, tal como existe no presente. Os métodos utilizados na pesquisa descritiva são levantamento de todos os tipos, inclusive de métodos comparativos e correlacionais. Walliman (2001) ressalta que a escala da pesquisa é influenciada por dois fatores principais: 1) o nível de complexidade da pesquisa; e 2) o escopo da pesquisa. 


\subsubsection{Abordagem Qualitativa}

A análise qualitativa, segundo Bardin (2011), corresponde a um procedimento mais intuitivo, mas também mais maleável e mais adaptável a índices não previstos, ou à evolução das hipóteses. Ela é válida, sobretudo, na elaboração das deduções específicas sobre um acontecimento ou uma variável de inferência precisa e não em inferências gerais.

Kothari (2004) acrescenta que a pesquisa qualitativa está preocupada com o fenômeno qualitativo, ou seja, os fenômenos relacionados com qualidade, ou envolvendo-a. Por exemplo, quando estamos interessados em investigar as razões para o comportamento humano (isto é, por que as pessoas pensam ou fazem certas coisas). Este tipo de pesquisa tem como objetivo descobrir os motivos subjacentes e desejos, usando entrevistas em profundidade para o efeito. Outras técnicas de tal pesquisa são os testes de associação de palavras, testes de completar frases, testes de conclusão de histórias e outras técnicas projetivas similares. Atitude ou opinião, ou seja, pesquisa, investigação destinada a descobrir como as pessoas se sentem ou o que pensam sobre um assunto ou instituição particular, também é a pesquisa qualitativa. A pesquisa qualitativa é especialmente importante nas ciências do comportamento, onde o objetivo é descobrir os motivos subjacentes do comportamento humano. Através dessa pesquisa, podemos analisar os diversos fatores que levam as pessoas a se comportarem de uma maneira particular, ou que as pessoas gostam ou não gostam de uma coisa particular.

Em resumo, pode-se dizer que o que caracteriza a análise qualitativa, de acordo com Bardin (2011), é o fato de a inferência - sempre que é realizada - ser fundamentada na presença do índice (tema, palavra, personagem, etc), e não sobre a frequência da sua aparição, em cada comunicação individual.

\subsubsection{Análise de conteúdo e análise documental}

A análise de conteúdo aparece como um conjunto de técnicas de análise das comunicações que utiliza procedimentos sistemáticos e objetivos de descrição do conteúdo das mensagens. A intenção é a inferência de conhecimentos relativos às condições de produção (ou, eventualmente, de recepção), inferência esta que recorre a indicadores, quantitativos ou não (BARDIN, 2011). 
Para Kothari (2004) a análise de conteúdo consiste em analisar o conteúdo de materiais documentais, como livros, revistas, jornais e os conteúdos de todos os outros materiais que podem ser verbais, falados ou impressos.

Para Minayo (2001), a análise de conteúdo é "compreendida muito mais como um conjunto de técnicas". Na visão da autora, constitui-se na análise de informações sobre o comportamento humano, possibilitando uma aplicação bastante variada, e tem duas funções: verificação de hipóteses e/ou questões e descoberta do que está por trás dos conteúdos manifestos. Tais funções podem ser complementares, com aplicação tanto em pesquisas qualitativas como quantitativas.

Acrescenta Kothari (2004) que a análise do conteúdo é uma atividade central, uma vez que está voltada para o estudo da natureza dos materiais verbais. Uma revisão da pesquisa em qualquer área, por exemplo, envolve a análise do conteúdo dos artigos de investigação que têm sido publicados. A análise pode ser a um nível relativamente simples ou pode ser uma subtil. É a um nível simples, quando praticá-la sobre a base de algumas das características do documento ou materiais verbais que podem ser identificadas e contadas (tal como na base dos principais conceitos científicos de um livro). Ele está em um nível sutil, quando o pesquisador faz um estudo da atitude, digamos, da imprensa em relação à educação por colunistas.

A análise documental permite passar de um documento primário (bruto) para um documento secundário (representação do primário). São, por exemplo, os resumos ou abstracts (sínteses do documento segundo certas regras); ou indexação, que permite, por classificação em palavras-chave, descritores ou índice, classificar os elementos de informação dos documentos, de maneira mais restrita (BARDIN, 2011).

Bardin (2011) afirma que as diferentes fases da análise de conteúdo, tal como o inquérito sociológico ou a experimentação, organizam-se em torno de três polos cronológicos: 1) a pré-análise; 2) a exploração do material e 3) o tratamento dos resultados, a inferência e a interpretação.

Tendo em vista as diferentes fases da análise de conteúdo proposta por Bardin (2011), destacam-se as dimensões da codificação e categorização que possibilitam e facilitam as interpretações e as inferências. No que tange à codificação, corresponde a uma transformação dos dados brutos do texto, transformação esta que, por recorte, agregação e enumeração, permite atingir uma representação do conteúdo, ou da sua expressão (MOZZATO; GRZYBOVSKI, 2011). Após a codificação, segue-se para a categorização, a qual consiste na: classificação de elementos constitutivos de um conjunto, por diferenciação e, seguidamente, por reagrupamento segundo o gênero (analogia), com os critérios previamente definidos. As 
categorias, são rubricas ou classes, as quais reúnem um grupo de elementos sob um título genérico, agrupamento esse efetuado em razão dos caracteres comuns destes elementos (MOZZATO; GRZYBOVSKI, 2011).

\subsection{COLETA DE DADOS E SELEÇÃO DAS PERGUNTAS ANALISADAS}

Kothari (2004) afirma que após a definição do problema de pesquisa e a confecção do plano de pesquisa, inicia-se a coleta de dados. A coleta de dados primários - aqueles que são recolhidos de novo e, pela primeira vez, e, assim sendo original em caráter - em caso de pesquisa do tipo descritiva, pode-se obter dados através de observação ou por meio de comunicação direta com os respondentes de uma forma ou outra, ou por meio de entrevistas pessoais. Existem vários métodos de coleta de dados primários, particularmente em estudos e pesquisas descritivas como, por exemplo, a análise de conteúdo.

Para alcançar os objetivos previamente estabelecidos para essa pesquisa, seguiu-se, de forma sistêmica, a busca de dados e sua conversão em informações. Dessa forma, fez-se necessário dividi-las em duas vertentes: a) a coleta do DP/2013/1, incluso a totalidade do material disponível, no que tange à opinião do IASB em relação às mudanças propostas para a Estrutura Conceitual, e as perguntas (totalizando 26 perguntas gerais) para as quais os preparadores, normatizadores e demais usuários enviariam suas opiniões e b) a coleta das comment letters, contendo as opiniões dos respondentes no tocante às perguntas propostas no DP/2013/1.

Para efeito de maior transparência e maior participação da classe contábil e demais interessados, o processo normativo do IASB consiste, entre outras etapas, na divulgação em sitio eletrônico do Discussion Paper e Exposure Draft referente à norma que se pretende criar ou modificar. Além desses, disponibiliza-se também as Comment Letters enviadas pelos profissionais (professores, entidades, etc.) no mesmo sitio eletrônico do IASB.

Para efeito desta pesquisa foi disponibilizado o Discussion Paper DP/2013/1 para o qual foram recebidas comment letters até 14 de janeiro de 2014 e que foram liberadas para acesso público até 31 de janeiro de 2014. Após leitura prévia do conteúdo transcrito no DP/2013/1, foram selecionadas as perguntas que se adequavam à resolução do problema de pesquisa e, por conseguinte, aos objetivos propostos, isto é, àquelas do tipo "concordo", "discordo" e "concordo parcialmente", sendo que foram eliminadas as perguntas de opiniões gerais, em que o IASB solicitou algum tipo de informação adicional sobre determinados assuntos. 
Das 26 (vinte e seis) perguntas totais, 22 foram selecionadas para futuro detalhamento, sendo elas sobre: introdução (1A e 1B); elementos das demonstrações financeiras (2A, 2B, 2C, 3A, 3B e 3C); orientações adicionais de apoio às definições de ativos e passivos (5 e 6); reconhecimento e desreconhecimento (8A, 8B e 9); definição de capital próprio e distinção entre passivos e instrumento de patrimônio (10A,10B, 10C e 10D); mensuração (11A, 11B, 11C, 11D, 11E, 11F, 12A, 12B, 12C, 12D, 13A, 13B, 13C, 14A, 14B e 14C); apresentação e divulgação (16A, 16B, 17 e 18); apresentação na demonstração de resultados abrangentes (19, 20 e 21) e outras questões $(22,23,24$ e 26$)$.

As questões de número 4 (quatro), 7 (sete), 15 (quinze) e 25 (vinte e cinco) foram excluídas da seleção, pois nelas, o IASB solicita algum comentário adicional acerca do assunto abordado nas questões anteriores - à medida que algum usuário dispunha aporte suplementar -, sendo optativas tais argumentações.

De posse dos primeiros dados coletados e a seleção das perguntas para as quais se obteria as opiniões dos respondentes, procedeu-se com a coleta das comment letters, com as opiniões gerais dos respondentes sobre as nove seções propostas no DP/2013/1. Foram obtidas todas as cartas recebidas pelo órgão, dentro do prazo estipulado, para respostas no DP (14 de janeiro de 2014), totalizando 227 comment letters, conforme apêndice A.

À medida que as cartas foram obtidas, prosseguiu-se com a leitura dinâmica (geral, não esmiuçada) delas, a fim de identificar as que se ajustavam à proposta da pesquisa, ou seja, àquelas que respondiam coerentemente todas as 44 perguntas (resultantes do desmembramento das 22 perguntas gerais), esboçando para elas argumentos ou não.

Essa fase é caracterizada por Bardin (2011) como pré-análise. Corresponde a um período de intuições, mas tem por objetivo tornar operacionais e sistematizar as ideias iniciais, de maneira a conduzir a um esquema preciso do desenvolvimento das operações sucessivas, num plano de análise. Nela ocorre a escolha dos documentos a serem submetidos à análise, a formulação das hipóteses e dos objetivos e a elaboração de indicadores que fundamentam a interpretação final.

\subsection{SELEÇÃO DA AMOSTRA}

Segundo Larson (2010), pelo teorema do limite central, quando $\mathrm{n} \geq 30$, a distribuição de amostragens das médias amostrais é uma distribuição normal. A validade de um método de estimativa aumenta, se uma amostra estatística não for tendenciosa e tiver baixa variabilidade. Uma estatística não é tendenciosa se não superestima ou subestima o parâmetro populacional. 
A média de todas as médias amostrais possíveis de mesmos tamanhos se iguala à média populacional. Como resultado, $\overline{\mathrm{x}}$ é um estimador não tendencioso de $\mu$. A preparação e seleção da amostra seguiram critérios específicos, sendo a população das cartas que responderam todas as perguntas, testadas empiricamente para validação final.

Do total de 227 comment letters, recepcionadas até 14 de janeiro de 2014, foram selecionadas aquelas que respondiam todas as perguntas ${ }^{14}$, perfazendo um total de 80 cartas, em que, de acordo com Larson (2010) e Gujarati e Porter (2011), é estatisticamente significante. A escolha das cartas em que os respondentes opinavam (de forma concordante, discordante ou parcialmente concordante) em todas as questões separadas para a pesquisa, se deve a busca por padrão das respostas, tendo em vista que se manteve o mesmo número de resposta para todas as perguntas, e, assim sendo, conservando as características semelhantes e não prejudicando a confrontação das respostas.

Para Bardin (2011) os documentos recolhidos devem ser homogêneos, isto é, devem obedecer a critérios precisos de escolha e não apresentar demasiada singularidade fora desses critérios. Nem todo o material de análise é suscetível de dar lugar a uma amostragem, e, nesse caso, mais vale abstermo-nos e reduzir o próprio universo (e, portanto, o alcance da análise), se este for demasiado importante. Tidos em conta alguns critérios, que dependem do objetivo da análise, pode proceder-se a uma redução pensada (amostragem) do universo e diminuir a parte submetida à análise.

Para confirmar a representatividade da amostra, foi aplicado o teste de erro amostral. Segundo Larson (2010, p. 252) o teorema do limite central descreve a relação entre a distribuição amostral de médias das amostras e a população das quais as amostras são tiradas. A distribuição amostral das médias das amostras tem um desvio padrão (também chamado de erro padrão da média) igual ao desvio padrão da população dividido pela raiz quadrada de $n$.

$$
\sigma_{\ddot{\mathrm{x}}}=Z_{\alpha} \frac{\sigma}{\sqrt{n}}
$$

Quando a amostragem é feita sem reposição e o tamanho da amostra $n$ é maior que 5\% da população finita de tamanho $\mathrm{N}(n / N>0,05)$, há um número finito de amostras possíveis. Um fator de correção finita deve ser usado para ajustar o erro padrão.

\footnotetext{
${ }^{14}$ Exceto as perguntas de número 4, 7, 15 e 25 as quais não tomaram parte da presente pesquisa, conforme justificado no item 3.2 coleta de dados e seleção das perguntas analisadas.
} 


$$
\sqrt{\frac{N-n}{N-1}}
$$

Assim:

$$
e=Z \alpha \frac{\sigma}{\sqrt{n}} \sqrt{\frac{\mathrm{N}-\mathrm{n}}{\mathrm{N}-1}}
$$

Onde:

$e=$ erro padrão

$Z_{\alpha}=$ nível de confiança

$\sigma=$ desvio padrão populacional 15

$\mathrm{N}=$ população conhecida e finita

$\mathrm{n}=$ tamanho da amostra

Utilizou-se o nível de confiança de $95 \%$, isto é, $\mathrm{Z}_{\alpha}=1,96$ de acordo com a tabela normal padrão explicada por Larson (2010), Gurajati e Porter (2011) Cochran (1977). Para efeito do cálculo, optou-se pela utilização do valor 0,5 para $\sigma$, tendo em vista que $s$, o desvio padrão da amostra - melhor estimativa não tendenciosa para $\sigma$ - não é conhecido.

Assim, o erro amostral calculado foi $e=0,0088366$, ou seja, menor que 5\%, corroborando a robustez da amostra.

\subsection{CONSTRUÇÃO DO INSTRUMENTO DE PESQUISA}

A segunda etapa da análise de conteúdo, conforme Bardin (2011), consiste na exploração do material. A fase de análise, não é mais do que a aplicação sistemática das decisões tomadas. Ela consiste, essencialmente, em operações de codificação, decomposição ou enumeração, em função de regras previamente formuladas.

Foi construído banco de dados, com a análise de cada carta, a fim de agregar informações tais como: número da carta, remetente, empresa/afiliação do remetente, quantidade de página da carta, carta resposta ou opinativa, tipo de remetente, setor, país de origem, continente de origem, interesse principal do respondente e o sistema contábil de seu país.

${ }^{15}$ Segundo Larson (2010, p. 278) a estimativa pontual para $\sigma^{2}$ é $s^{2}$ e a estimativa pontual para $\sigma$ é s. $s^{2}$ é a melhor estimativa não tendenciosa para $\sigma^{2}$. Quando $\sigma$ não é conhecido, porém $n$ é $\geq 30$, utiliza-se s (desvio padrão da amostra). 
O instrumento de pesquisa foi confeccionado com base no manual prático de Bardin (2011) no qual é exposto a prática, o método (pré-análise, exploração do material e tratamento dos resultados obtidos e interpretação) e técnica (análise categorial) da análise de conteúdo.

No que tange ao tipo de material, foi utilizada a análise de respostas a questões abertas. Segundo Bardin (2011) o material verbal obtido a partir de questões abertas é muito mais rico em informações do que as respostas a questões fechadas.

Quanto à técnica, utilizou-se a análise categorial. Conforme Bardin (2011) foram realizadas operações de desmembramento do texto em unidades, em categorias segundo reagrupamentos analógicos.

\subsection{ANÁLISE DAS COMMENT LETTERS}

Após o planejamento do instrumento de pesquisa, foram analisadas e tabuladas todas as 80 comment letters, de uma forma não mecanizada, devido a suas limitações primárias, como a não interpretação do conteúdo com base no contexto.

A construção do instrumento de pesquisa foi realizada de forma qualitativa, porém, a análise deste instrumento, foi realizada de forma quantitativa e a apresentação dos resultados também assim se procedeu.

No que tange à leitura das cartas, para efeito de construção do instrumento de pesquisa, se deu conforme ordem de recebimento e divulgação ao público pelo IASB em seu sitio eletrônico, tendo em vista que os respondentes se equivalem (nenhum grupo de respondente possui maior interesse quanto à proposta de alteração da Estrutura Conceitual em detrimento dos demais).

Na primeira etapa da análise, cada uma das 80 cartas foi lida integralmente ${ }^{16}$ - todas as perguntas e respostas em sequência - e, foram obtidas as respostas para cada pergunta em duas vertentes: a) se o respondente concordava, discordava ou concordava parcialmente com o assunto proposto para a questão em análise; e b) se o respondente embasava sua resposta e que tipo de argumento utilizava.

Para classificação dos tipos de argumentos, a presente pesquisa baseou-se na investigação de Yen, Hirst e Hopkins (2007). Foram realizadas algumas adaptações devido à singularidade da Estrutura Conceitual, conforme Quadro 3.

\footnotetext{
${ }^{16}$ Exceto para pré-análise em que foram lidas todas as 272 comment letters.
} 
No tocante a segunda etapa da análise, seguiu-se a investigação por pergunta. As comment letters foram lidas novamente, porém, em ordem de perguntas (não por carta). A fim de estabelecer padrão para os argumentos dados, cada pergunta foi lida em todas as cartas e, sequencialmente, tabulados os argumentos dados. Nessa etapa o objetivo foi estabelecer os principais argumentos utilizados, classificar os argumentos principais e secundários e efetuar a contagem dos argumentos, pergunta por pergunta.

Quadro 3 - Classificação da taxonomia dos argumentos utilizados

\begin{tabular}{|c|c|}
\hline $\begin{array}{c}\text { Tipo de } \\
\text { Argumento }\end{array}$ & Característica \\
\hline Definição & $\begin{array}{l}\text { Argumentos em que as concordâncias, discordâncias e concordâncias parciais com o modelo } \\
\text { contábil, se utilizam de bases teóricas ou definições, tais como expostas na Estrutura } \\
\text { Conceitual ou definição exibida em outra norma. }\end{array}$ \\
\hline Escopo & $\begin{array}{l}\text { Argumentos em que os respondentes expõem seu ponto de vista com base em experiência } \\
\text { prática, ou no que acham, sem quaisquer utilizações de definições ou bases teóricas. }\end{array}$ \\
\hline Due process & $\begin{array}{l}\text { Argumentos para os quais os respondentes embasavam suas respostas citando outras normas } \\
\text { ou a Estrutura Conceitual, confrontando ou não com a proposta do DP/2013/1. }\end{array}$ \\
\hline $\begin{array}{l}\text { Efeitos Externos } \\
\text { e Internos }\end{array}$ & $\begin{array}{c}\text { Argumentos em que os respondentes citavam implicações para os usuários externos e } \\
\text { internos. }\end{array}$ \\
\hline Exemplos & Argumentos para os quais os usuários citavam exemplos teóricos ou práticos. \\
\hline Sem Argumento & $\begin{array}{l}\text { Respostas sem argumentos, em que os respondentes apenas apresentavam opinião quanto à } \\
\text { concordância, discordância ou concordância parcial. }\end{array}$ \\
\hline
\end{tabular}

Fonte: Adaptado de Yen, Hirst e Hopkins (2007)

Por fim, procedeu-se ao tratamento dos dados obtidos e sua interpretação. Conforme Bardin (2011) os resultados brutos foram tratados de maneira a serem significativos e válidos para a pesquisa. Operações estatísticas simples (estatística descritiva), ou mais complexas (estatística inferencial) foram realizadas com o intuito de estabelecer os resultados (Seção seguinte), evidenciados através de tabelas e figuras, os quais põem em relevo as informações fornecidas pela análise.

Com base nos resultados alcançados para a amostra de 80 comment letters, pode-se propor inferências e adiantar interpretações a propósito dos objetivos previstos, conforme Bardin (2011), tendo em vista que se teve à disposição resultados significativos e fiéis. 


\section{RESULTADOS E ANÁLISES}

Neste capítulo são propostos à exibição e à discussão dos essenciais resultados constatados durante a execução dos procedimentos descritos no capítulo anterior. Ele se subdivide em três seções, descritas na continuação.

Na primeira seção, são apresentados o perfil da amostra, por: setores de atuação, país de origem e sistema contábil do país de origem.

$\mathrm{Na}$ segunda seção, são exibidos e analisados os resultados referentes ao nível de concordância e discordância, referentes às perguntas sobre as seções discutidas no Discussion Paper DP/2013/1.

$\mathrm{Na}$ terceira seção, e destacada a taxonomia dos argumentos, evidenciando os tipos de argumentos utilizados pelos respondentes, com a finalidade de interpretar como estes justificavam suas opiniões e as expressavam para o IASB com relação à proposta de revisão da Estrutura Conceitual.

Em todos os procedimentos realizados, os conjuntos de dados foram analisados em conjunto - todas as questões que fazem parte da amostra - seguidos de análise por cada seção do DP/2013/1, totalizando 9 seções: 1) introdução; 2) elementos das demonstrações financeiras; 3) orientações adicionais de apoio às definições de ativo e passivos; 4) reconhecimento e desreconhecimento; 5) definição de capital próprio e distinção entre passivos e instrumento de patrimônio; 6) mensuração; 7) apresentação e divulgação; 8) apresentação na demonstração de resultados abrangentes e 9) outras questões.

Foram analisadas 80 comment letters, 1747 páginas, com uma média de 21,84 páginas por carta. Foram tabuladas as opiniões de cada respondente para as perguntas analisadas de forma individualizada, totalizando 3520 opiniões, e a mesma quantidade de taxonomias dos argumentos utilizados pelos respondentes. No que tange aos argumentos utilizados pelos respondentes, obteve-se as descrições das opiniões dos respondentes.

Foram investigadas outras pesquisas - as quais possuíam metodologias semelhantes e que esmiuçaram outras normas e demais averiguações, que exploraram a Estrutura Conceitual para Elaboração de Relatórios Financeiros - e seus resultados, a fim de comparar com aqueles obtidos nesta pesquisa. 


\subsection{PERFIL DA AMOSTRA}

Previamente, com a finalidade de amplificar a percepção dos resultados da investigação, fez-se imperativo a decomposição e apreciação do perfil da amostra, considerando suas universalidades, exterioridades e particularidades e as efetivas correspondências entre os elementos explorados.

No que tange a localidade de origem, a Tabela 1 evidencia a quantidade e o percentual de cartas encaminhadas pelos diferentes continentes.

Tabela 1 - Quantidade de Respostas por Continente de Origem

\begin{tabular}{|c|c|c|c|}
\hline \# & Continente de Origem & Quantidade & $\%$ \\
\hline & Europa & 39 & $48,75 \%$ \\
\hline & Ásia & 15 & $18,75 \%$ \\
\hline & América $^{17}$ & 13 & $16,25 \%$ \\
\hline & Oceania & 9 & $11,25 \%$ \\
\hline & África & 1 & $1,25 \%$ \\
\hline \multirow{2}{*}{\multicolumn{2}{|c|}{$\begin{array}{ll}6 & \text { Outros } \\
& \text { Total Geral }\end{array}$}} & 3 & $3,75 \%$ \\
\hline & & 80 & $100,00 \%$ \\
\hline
\end{tabular}

Fonte: Dados da Pesquisa

As comment letters recebidas do continente Europeu representam 48,75\% do total da amostra, seguido pelo continente Asiático com 18,75\%. Essa conduta foi convergente com a totalidade das cartas - 227 comment letters - recepcionadas pelo IASB, conforme evidenciado em seu sitio eletrônico. Porém, em relação aos percentuais, resultados diferentes são encontrados, sendo que, as cartas recebidas do continente Europeu representam 37 pontos percentuais do universo, seguido por 19 pontos percentuais, recepcionadas do continente Asiático.

Adicionalmente, a Tabela 2 revela as participações com base no país de origem. As comment letters enviadas do Reino Unido representam $23,75 \%$ da totalidade da amostra, seguido por Austrália, Alemanha, EUA e Canadá, com 7,5\%, 6,25\%, 5\% e 5\%, respectivamente. Essa conduta foi percebida em outras investigações que pesquisaram comment letters, como Larson $(2008)^{18}$, Maglio (2011) ${ }^{19}$ e Holder et al., (2013), quanto à

\footnotetext{
17 América = EUA: 4, Canadá: 4, Brasil: 3, México 1 e outros: 1 (Associação de emissores de Normas da América Latina).

${ }^{18}$ Larson (2008) examinou comment letters acerca das Sociedades de Proposito Especifico (SPE).

${ }^{19}$ Maglio (2011) examinou comment letters sobre o Discussion Paper do IASB, Financial Instruments with Characteristics of Equity.
} 
maioria das cartas sendo enviadas do Reino Unido. Em relação à pesquisa se Larson (2008), o Reino Unido é seguido por Australia, EUA e França. Já a Pesquisa de Maglio (2011) segue-se por EUA, Alemanha e Canadá. Para Holder et al., (2013) o Reino Unido é seguido por Alemanha, EUA e Austrália.

Tabela 2 - Quantidade de Respostas por País de Origem

\begin{tabular}{|c|c|c|c|}
\hline$\#$ & País de Origem & Quant. & $\%$ \\
\hline 1 & Reino Unido & 19 & $23,75 \%$ \\
\hline 2 & Austrália & 6 & $7,50 \%$ \\
\hline 3 & Alemanha & 5 & $6,25 \%$ \\
\hline 4 & EUA & 4 & $5,00 \%$ \\
\hline 5 & Canadá & 4 & $5,00 \%$ \\
\hline 6 & Brasil & 3 & $3,75 \%$ \\
\hline 7 & China (Hong Kong) & 3 & $3,75 \%$ \\
\hline 8 & Índia & 3 & $3,75 \%$ \\
\hline 9 & França & 2 & $2,50 \%$ \\
\hline 10 & Singapura & 2 & $2,50 \%$ \\
\hline 11 & Suíça & 2 & $2,50 \%$ \\
\hline 12 & Espanha & 2 & $2,50 \%$ \\
\hline 13 & Japão & 2 & $2,50 \%$ \\
\hline 14 & Malásia & 2 & $2,50 \%$ \\
\hline 15 & Áustria & 1 & $1,25 \%$ \\
\hline 16 & China & 1 & $1,25 \%$ \\
\hline 17 & Coreia do Sul & 1 & $1,25 \%$ \\
\hline 18 & Dinamarca & 1 & $1,25 \%$ \\
\hline 19 & Holanda & 1 & $1,25 \%$ \\
\hline 20 & Lituânia & 1 & $1,25 \%$ \\
\hline 21 & Nova Zelândia & 1 & $1,25 \%$ \\
\hline 22 & Paquistão & 1 & $1,25 \%$ \\
\hline 23 & Polônia & 1 & $1,25 \%$ \\
\hline 24 & Rússia & 1 & $1,25 \%$ \\
\hline 25 & Suécia & 1 & $1,25 \%$ \\
\hline 26 & México & 1 & $1,25 \%$ \\
\hline 27 & Bélgica & 1 & $1,25 \%$ \\
\hline 28 & Outros: África do Sul & 1 & $1,25 \%$ \\
\hline 29 & Outros: América Latina & 1 & $1,25 \%$ \\
\hline 30 & Outros: Ásia-Oceania & 1 & $1,25 \%$ \\
\hline 31 & Outros: Australásia & 1 & $1,25 \%$ \\
\hline 32 & Outros: América do Norte e Europa & 1 & $1,25 \%$ \\
\hline 33 & Outros: Europa & 2 & $2,50 \%$ \\
\hline \multirow[t]{2}{*}{34} & Outros & 1 & $1,25 \%$ \\
\hline & Total Geral & 80 & $100,00 \%$ \\
\hline
\end{tabular}


Outras pesquisas evidenciaram comportamentos distintos destes, como Larson e Brown (2001) e Matos (2013), que identificaram como principal país de origem das comment letters enviadas ao IASB, os EUA.

Assim como já destacado na análise por continente, ocorre maior participação dos países europeus, tanto em relação a quantidade de cartas enviadas, quanto à quantidade de países participantes, apontando que os países europeus estão mais comprometidos com o processo normativo do IASB e interessados em cooperar para o desenvolvimento e alterações das normas. Além disso, as circunstâncias, o nível de convergência aos padrões contábeis internacionais e a forte influência dos países europeus no processo normativo, podem fundamentar a maior participação desses países.

Adicionalmente destaca-se a participação do Brasil, figurando na $6^{\mathrm{a}}$ posição do ranking, atrás apenas do Reino Unido, Austrália, Alemanha, EUA e Canadá. Esse fato representa uma evolução da classe contábil no que tange sua participação no processo normativo do IASB. A justificativa para essa evolução pode ser a adoção das normas do IASB, a partir da criação do Comitê de Pronunciamentos Contábeis (CPC) e a emissão das Leis: 11.638/07 e 11.941/08, que permitiu que o Brasil se afastasse de um sistema contábil baseado em regras - seguido ao longo de vários anos - e a aproximação de um sistema contábil baseado em princípios. A adoção de normas mais flexíveis, em linhas gerais, objetiva maior qualidade da informação contábil, utilizando-se julgamento profissional no que tange aos critérios de reconhecimento, mensuração e evidenciação e, desta forma, crescimento da classe contábil, tornando-a forte. Esses fatores podem tem motivado os profissionais da contabilidade no Brasil a participaram mais ativamente do processo normativo do IASB, tendo em vista que as consequências são diretas para as politicas e práticas contábeis adotadas no Brasil.

Os pressupostos anteriores são confirmados quando se compara a pesquisa em questão com a investigação de Matos (2013) em que se percebe evolução da participação do Brasil no processo normativo do IASB. Segundo o autor, o Brasil ocupava a $12^{\circ}$ posição no ranking de respondentes do ED/2010/9.

No tocante a participação dos continentes no envio de comment letters, em especial a elevada participação dos países europeus e o envolvimento desses no processo normativo do IASB, a quantidade de comment letters enviadas por sistema contábil ratifica os pressupostos previamente destacados, conforme a Figura 1. A maioria das cartas, totalizando 50 - 
equivalente a 62,5 pontos percentuais - foi enviada de países onde o sistema contábil de origem é Anglo-Saxão.

\section{Figura 1 - Quantidade de Respostas por Sistema Contábil}

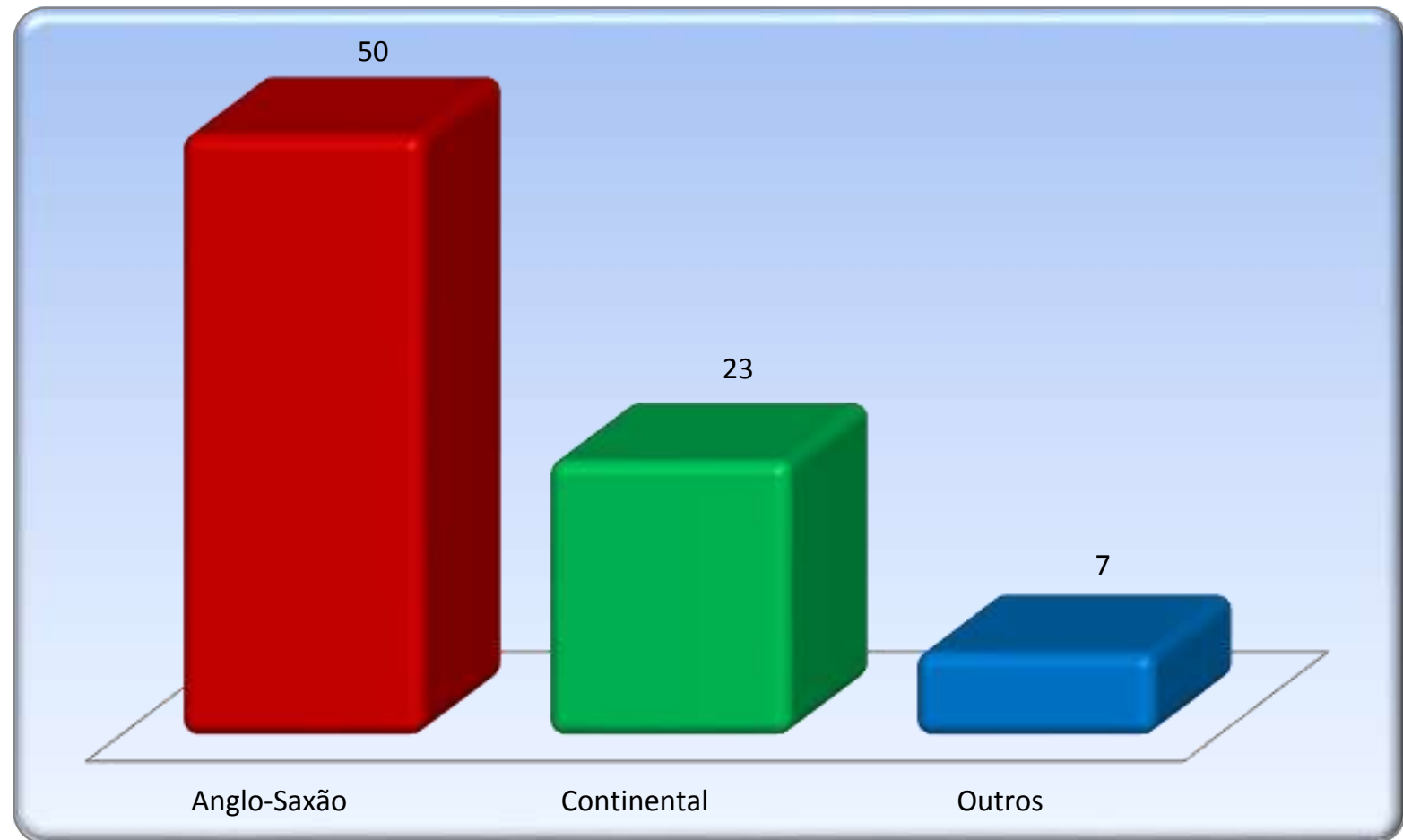

Fonte: Dados da Pesquisa

Resultado semelhante aos encontrados em Maglio (2011) e Matos (2013). As evidências do próprio modelo, podem justificar essa participação, principalmente quanto às afirmativas feitas por Choi e Meek (2011), Niyama (2010), Saudagaran (2004), no que diz respeito à existência de uma profissão contábil forte e atuante, com pouca interferência governamental na definição de práticas contábeis e as demonstrações financeiras, buscando atender, em primeiro lugar, os investidores, características que conduzem a melhores relatórios financeiros e, portanto, maior qualidade da informação contábil.

Quanto à esfera de atuação, a Tabela 3 destaca a quantidade de comment letters encaminhadas ao IASB pelos diversos setores. Percebe-se que Normatizadores correspondem a 27,5 pontos percentuais da totalidade da amostra, seguido por Associação de Classe. Esse resultado difere dos achados alusivos à pesquisa realizada por Matos (2013) onde os Serviços Profissionais figuravam no ápice do ranking.

Esse fato pode ser explicado pelo objetivo e alcance da Norma e a Estrutura Conceitual, tendo em vista que, em se tratando da norma de leasing, os preparadores gerais 
são diretamente afetados e, portanto, apresentando maior interesse e participação quanto ao envio de cartas ao IASB, referentes ao ED/2010/9.

Por sua vez, a Estrutura Conceitual, entre outros objetivos, tem por ênfase assessorar o IASB e demais órgãos normatizadores, no desenvolvimento e alterações de outras normas, suscitando o interesse, sobretudo desses em detrimento dos demais.

Tabela 3 - Quantidade de Resposta por Setor de Atuação

\begin{tabular}{|c|c|c|c|c|c|c|c|}
\hline & Setores & Quant. & $\%$ & & Setores & Quant. & $\%$ \\
\hline 1 & Normatizadores & 22 & $27,50 \%$ & 8 & Federação das Indústrias ${ }^{20}$ & 1 & $1,25 \%$ \\
\hline 2 & Associação Profissional & 20 & $25,00 \%$ & 9 & Gás e Industria $^{20}$ & 1 & $1,25 \%$ \\
\hline & Serviços Financeiros ${ }^{20}$ & 9 & $11,25 \%$ & 10 & $\begin{array}{l}\text { Proteção de cultivos e } \\
\text { biotecnologia }^{20}\end{array}$ & 1 & $1,25 \%$ \\
\hline & Auditoria & 8 & $10,00 \%$ & 11 & Ind. e Com. Tabaco 20 & 1 & $1,25 \%$ \\
\hline & Academia & 7 & $8,75 \%$ & 12 & Mineração $^{20}$ & 1 & $1,25 \%$ \\
\hline & $\begin{array}{l}\text { Contabilidade e } \\
\text { Consultoria }^{20}\end{array}$ & 4 & $5,00 \%$ & 13 & Petróleo e Energia ${ }^{20}$ & 1 & $1,25 \%$ \\
\hline & Mercado de Capitais $^{21}$ & 3 & $3,75 \%$ & 14 & Construção e Engenharia $^{20}$ & 1 & $1,25 \%$ \\
\hline & & & & & Total & 80 & $100,00 \%$ \\
\hline
\end{tabular}

Fonte: Dados da Pesquisa

\subsection{NÍVEL DE CONCORDÂNCIA E DISCORDÂNCIA}

Com a finalidade de identificar as questões de maior aceitação e as de maior rejeição pelos respondentes, foi analisado o nível de concordância ou de discordância em relação às questões sobre as seções propostas no DP/2013/1: 1) introdução; 2) elementos das demonstrações financeiras; 3) orientações adicionais de apoio às definiçõoes de ativo e passivos; 4) reconhecimento e desreconhecimento; 5) definição de capital próprio e distinção entre passivos e instrumento de patrimônio; 6) mensuração; 7) apresentação e divulgação; 8) apresentação na demonstração de resultados abrangentes; e 9) outras questões.

Em princípio, foi executada uma análise geral, contemplando todas as 44 perguntas analisadas, seguida por avaliação pormenorizada, seção por seção - aquelas supracitadas - e, pergunta a pergunta. Fez-se necessária análise detalhada devido às particularidades existentes em cada seção, tendo em vista que nessas, as questões foram agrupadas por assunto. A tabela 4 destaca a opinião dos respondentes para todas as questões, evidenciando o nível de Concordância ou Discordância por pergunta e na totalidade.

\footnotetext{
${ }^{20}$ Setores detalhados inclusos em Preparadores

${ }^{21}$ Setor incluso em Regulador
} 
Constata-se que o número de perguntas de cada seção é heterogêneo, gerando quantidade distinta de resposta por seção. A seção 6-Mensuração, apresenta o maior número de perguntas, totalizando 16. Já as seções 1 - Introdução e 3 - Orientação adicional de apoio às definições de ativo e passivo, são aquelas que exibem o menor número, sendo apenas 2 perguntas, cada uma delas.

Os resultados gerais evidenciaram um total de 3.520 respostas - correspondente ao número total da amostra, multiplicado pela quantidade de perguntas observadas. De maneira geral, o nível de concordância perfaz um percentual de 69,72, seguido por 9,38 e 20,91 pontos percentuais, respectivamente para o nível de opiniões parciais - aqueles que concordavam em alguns aspectos e discordavam em outros - e discordância. Em comparação com Matos (2013) percebe-se maior nível de concordância, tendo em vista que os resultados daquela pesquisa apontaram nível de concordância de $46 \%$ e discordância de $39 \%$.

Esse fato pode ser justificado pela própria natureza da norma de leasing e a Estrutura Conceitual, visto que, em se tratando daquela, as mudanças propostas afetavam diretamente os usuários no que tange aos aspectos referentes à mensuração, reconhecimento e evidenciação dos elementos das demonstrações contábeis.

Segundo Matos (2013), o IASB propõe modelos de contabilização distintos para as arrendadoras e para as arrendatárias com o objetivo de diminuir as críticas antes realizadas, como a estruturação de operações, o off-balance, os testes bright-line e a suscetibilidade das normas sobre leasing a manipulações contábeis. Com base no ED/2010/9, que, para as arrendatárias, quanto ao reconhecimento há a proposta do "direito de uso": todos os contratos de leasing serão capitalizados no ativo e um respectivo passivo referente às obrigações com relação a tal direito será constituído em contrapartida. Já para as arrendadoras, dois métodos são possíveis: o performance obligation approach e o derecognition approach. Os modelos devem ser utilizados com base na exposição do arrendador ao risco sobre o bem arrendado.

Já a Estrutura Conceitual - apesar de produzir reflexos indiretos nos relatórios financeiros - evidencia conteúdo teórico e de natureza orientadora para os órgãos normatizadores e demais usuários. As mutações propostas afetam elevada gama de usuários, conduzindo-os nas elaborações, modificações, interpretações e explicações de normas que dão origem, não só as demonstrações financeiras primárias, mas aos relatórios financeiros de propósito geral, no que tange aos elementos de reconhecimento, mensuração e evidenciação. 
Tabela 4 - Nível de Concordância/Discordância por Pergunta e Geral

\begin{tabular}{|c|c|c|c|c|c|c|c|c|}
\hline Seção & Pergunta & Concordo & А.Н. \% & Parcial & А.Н.\% & Dis corde & А.Н.\% & Total \\
\hline \multirow{2}{*}{ Introdução } & $1 \mathrm{~A}$ & 46 & $57,50 \%$ & 23 & $28,75 \%$ & 11 & $13,75 \%$ & 80 \\
\hline & $1 \mathrm{~B}$ & 57 & $71,25 \%$ & 10 & $12,50 \%$ & 13 & $16,25 \%$ & 80 \\
\hline & Total & 103 & $64,38 \%$ & 33 & $20,63 \%$ & 24 & $15,00 \%$ & 160 \\
\hline \multirow{7}{*}{$\begin{array}{l}\text { Elementos dos Relatórios } \\
\text { Financeiros }\end{array}$} & $2 \mathrm{~A}$ & 56 & $70,00 \%$ & 9 & $11,25 \%$ & 15 & $18,75 \%$ & 80 \\
\hline & $2 \mathrm{~B}$ & 59 & $73,75 \%$ & 7 & $8,75 \%$ & 14 & $17,50 \%$ & 80 \\
\hline & $2 \mathrm{C}$ & 60 & $75,00 \%$ & 7 & $8,75 \%$ & 13 & $16,25 \%$ & 80 \\
\hline & $3 \mathrm{~A}$ & 61 & $76,25 \%$ & 4 & $5,00 \%$ & 15 & $18,75 \%$ & 80 \\
\hline & $3 B$ & 50 & $62,50 \%$ & 7 & $8,75 \%$ & 23 & $28,75 \%$ & 80 \\
\hline & $3 C$ & 43 & $53,75 \%$ & 8 & $10,00 \%$ & 29 & $36,25 \%$ & 80 \\
\hline & Total & 329 & $68,54 \%$ & 42 & $8,75 \%$ & 109 & $22,71 \%$ & 480 \\
\hline \multirow{3}{*}{$\begin{array}{l}\text { Orientação Adicional de Apoio } \\
\text { as Definições de Ativo e Passivo }\end{array}$} & 5 & 70 & $87,50 \%$ & 10 & $12,50 \%$ & 0 & $0,00 \%$ & 80 \\
\hline & 6 & 65 & $81,25 \%$ & 7 & $8,75 \%$ & 8 & $10,00 \%$ & 80 \\
\hline & Total & 135 & $84,38 \%$ & 17 & $10,63 \%$ & 8 & $5,00 \%$ & 160 \\
\hline \multirow{4}{*}{$\begin{array}{l}\text { Reconhecimento e } \\
\text { Desreconhecimento }\end{array}$} & $8 \mathrm{~A}$ & 48 & $60,00 \%$ & 9 & $11,25 \%$ & 23 & $28,75 \%$ & 80 \\
\hline & $8 \mathrm{~B}$ & 47 & $58,75 \%$ & 12 & $15,00 \%$ & 21 & $26,25 \%$ & 80 \\
\hline & 9 & 47 & $58,75 \%$ & 9 & $11,25 \%$ & 24 & $30,00 \%$ & 80 \\
\hline & Total & 142 & $59,17 \%$ & 30 & $12,50 \%$ & 68 & $28,33 \%$ & 240 \\
\hline \multirow{4}{*}{$\begin{array}{l}\text { Definição de PL e Distinção de } \\
\text { Passivo e Instrumento de Capital }\end{array}$} & $10 \mathrm{~A}$ & 65 & $81,25 \%$ & 3 & $3,75 \%$ & 12 & $15,00 \%$ & 80 \\
\hline & $10 \mathrm{~B}$ & 55 & $68,75 \%$ & 6 & $7,50 \%$ & 19 & $23,75 \%$ & 80 \\
\hline & $10 \mathrm{C}$ & 33 & $41,25 \%$ & 4 & $5,00 \%$ & 43 & $53,75 \%$ & 80 \\
\hline & $10 \mathrm{D}$ & 30 & $37,50 \%$ & 6 & $7,50 \%$ & 44 & $55,00 \%$ & 80 \\
\hline & Total & 183 & $57,19 \%$ & 19 & $5,94 \%$ & 118 & $36,88 \%$ & 320 \\
\hline \multirow{17}{*}{ Mensuração } & $11 \mathrm{~A}$ & 65 & $81,25 \%$ & 5 & $6,25 \%$ & 10 & $12,50 \%$ & 80 \\
\hline & $11 \mathrm{~B}$ & 69 & $86,25 \%$ & 5 & $6,25 \%$ & 6 & $7,50 \%$ & 80 \\
\hline & $11 \mathrm{C}$ & 68 & $85,00 \%$ & 5 & $6,25 \%$ & 7 & $8,75 \%$ & 80 \\
\hline & $11 \mathrm{D}$ & 58 & $72,50 \%$ & 10 & $12,50 \%$ & 12 & $15,00 \%$ & 80 \\
\hline & $11 \mathrm{E}$ & 67 & $83,75 \%$ & 3 & $3,75 \%$ & 10 & $12,50 \%$ & 80 \\
\hline & $11 \mathrm{~F}$ & 73 & $91,25 \%$ & 4 & $5,00 \%$ & 3 & $3,75 \%$ & 80 \\
\hline & $12 \mathrm{~A}$ & 56 & $70,00 \%$ & 7 & $8,75 \%$ & 17 & $21,25 \%$ & 80 \\
\hline & $12 \mathrm{~B}$ & 52 & $65,00 \%$ & 7 & $8,75 \%$ & 21 & $26,25 \%$ & 80 \\
\hline & $12 \mathrm{C}$ & 55 & $68,75 \%$ & 7 & $8,75 \%$ & 18 & $22,50 \%$ & 80 \\
\hline & $12 \mathrm{D}$ & 50 & $62,50 \%$ & 6 & $7,50 \%$ & 24 & $30,00 \%$ & 80 \\
\hline & $13 \mathrm{~A}$ & 60 & $75,00 \%$ & 4 & $5,00 \%$ & 16 & $20,00 \%$ & 80 \\
\hline & $13 \mathrm{~B}$ & 58 & $72,50 \%$ & 3 & $3,75 \%$ & 19 & $23,75 \%$ & 80 \\
\hline & $13 \mathrm{C}$ & 58 & $72,50 \%$ & 4 & $5,00 \%$ & 18 & $22,50 \%$ & 80 \\
\hline & $14 \mathrm{~A}$ & 59 & $73,75 \%$ & 4 & $5,00 \%$ & 17 & $21,25 \%$ & 80 \\
\hline & $14 \mathrm{~B}$ & 59 & $73,75 \%$ & 4 & $5,00 \%$ & 17 & $21,25 \%$ & 80 \\
\hline & $14 \mathrm{C}$ & 60 & $75,00 \%$ & 4 & $5,00 \%$ & 16 & $20,00 \%$ & 80 \\
\hline & Total & 967 & $75,55 \%$ & 82 & $6,41 \%$ & 231 & $18,05 \%$ & 1280 \\
\hline \multirow{5}{*}{ Apresentação e Divulgação } & $16 \mathrm{~A}$ & 52 & $65,00 \%$ & 15 & $18,75 \%$ & 13 & $16,25 \%$ & 80 \\
\hline & $16 \mathrm{~B}$ & 51 & $63,75 \%$ & 13 & $16,25 \%$ & 16 & $20,00 \%$ & 80 \\
\hline & 17 & 58 & $72,50 \%$ & 10 & $12,50 \%$ & 12 & $15,00 \%$ & 80 \\
\hline & 18 & 67 & $83,75 \%$ & 6 & $7,50 \%$ & 7 & $8,75 \%$ & 80 \\
\hline & Total & 228 & $71,25 \%$ & 44 & $13,75 \%$ & 48 & $15,00 \%$ & 320 \\
\hline \multirow{4}{*}{$\begin{array}{c}\text { Apresentação na DRA - Lucros } \\
\text { e Perdas e ORA }\end{array}$} & 19 & 66 & $82,50 \%$ & 5 & $6,25 \%$ & 9 & $11,25 \%$ & 80 \\
\hline & 20 & 47 & $58,75 \%$ & 11 & $13,75 \%$ & 22 & $27,50 \%$ & 80 \\
\hline & 21 & 54 & $67,50 \%$ & 2 & $2,50 \%$ & 24 & $30,00 \%$ & 80 \\
\hline & Total & 167 & $69,58 \%$ & 18 & $7,50 \%$ & 55 & $22,92 \%$ & 240 \\
\hline \multirow{5}{*}{ Outras Questões } & 22 & 34 & $42,50 \%$ & 14 & $17,50 \%$ & 32 & $40,00 \%$ & 80 \\
\hline & 23 & 55 & $68,75 \%$ & 12 & $15,00 \%$ & 13 & $16,25 \%$ & 80 \\
\hline & 24 & 55 & $68,75 \%$ & 12 & $15,00 \%$ & 13 & $16,25 \%$ & 80 \\
\hline & 26 & 56 & $70,00 \%$ & 7 & $8,75 \%$ & 17 & $21,25 \%$ & 80 \\
\hline & Total & 200 & $62,50 \%$ & 45 & $14,06 \%$ & 75 & $23,44 \%$ & 320 \\
\hline \multicolumn{2}{|r|}{ Total Geral } & 2454 & $69,72 \%$ & 330 & $9,38 \%$ & 736 & $20,91 \%$ & 3520 \\
\hline
\end{tabular}

Fonte: Dados da Pesquisa 
A seção com maior nível de concordância foi a seção 3 - Orientação Adicional de Apoio às Definições de Ativo e Passivo, atingindo 84,38 pontos percentuais de concordância, seguida pela seção 6 - Mensuração, alcançando 75,55 pontos percentuais. No tocante à discordância, a seção 5 - Definição de Patrimônio Líquido e Distinção de Passivo e Instrumento de Capital, emergem em primeiro lugar, perfazendo 36,88 pontos percentuais, seguida pela seção 4 - Reconhecimento e Desreconhecimento, com 28,33.

Adicionalmente, designou-se analisar o nível de concordância por setor de atuação dos respondentes, de acordo com a Figura 2. Em termos absolutos, o maior número de concordância foi alcançado no grupo Normatizadores, seguido por Preparadores e Associação Profissional. Em se tratando do maior nível de discordância, novamente os Normatizadores surgem na primeira posição, porém seguido por Associação Profissional e Preparadores.

A justificativa para a presença desses grupos com maior número de concordância e discordância se deve ao maior número de cartas enviadas por eles em relação aos demais.

Figura 2 - Nível de Concordância por Setor de Atuação

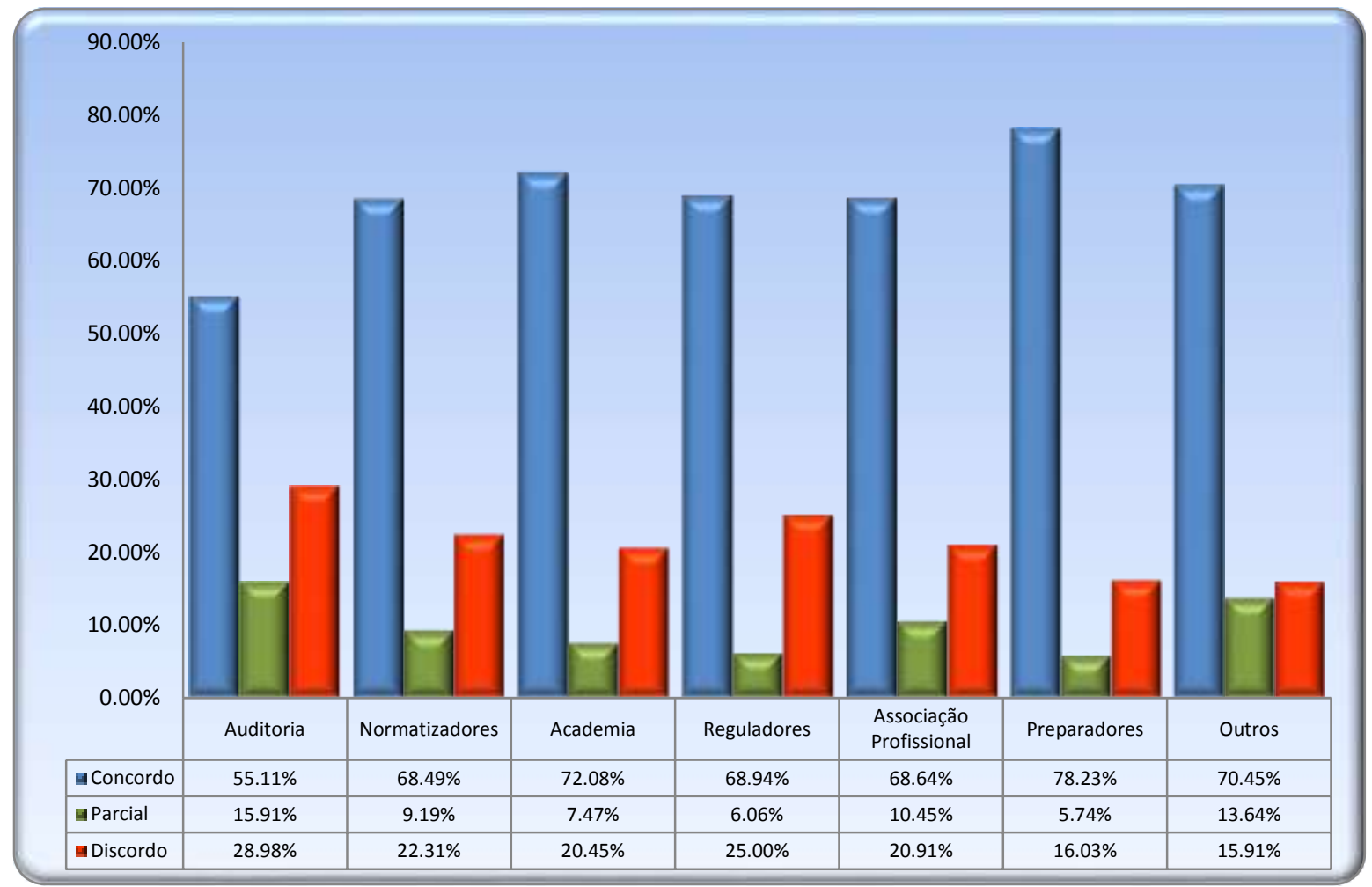

Fonte: Dados da Pesquisa

Por outro lado, quanto à análise relativa - análise de cada elemento dentro do próprio grupo -, percebe-se que o maior nível de concordância fica por conta dos Preparadores que concordam com a proposta do IASB em relação às perguntas do DP/2013/1 (cerca de 78\% das 
respostas fornecidas). Em segundo lugar, surge o grupo Academia, concordando $72 \%$ das respostas. O maior nível de discordância foram os grupos Auditoria e Reguladores (cerca de 29 e 25 pontos percentuais, respectivamente).

\subsubsection{Introdução}

Nessa seção há duas perguntas $(1 \mathrm{~A} \text { e } 1 \mathrm{~B})^{22}$, como resultado do desmembramento da pergunta número 1 . A pergunta $1 \mathrm{~A}$ diz respeito ao propósito primário da Estrutura Conceitual e a pergunta 1B refere-se aos possíveis conflitos existentes entre Normas (Existentes e as que vierem a ser criadas) e a Estrutura Conceitual emitida pelo IASB.

A Figura 3 solidifica a conduta dos respondentes alusiva à concordância e discordância - pergunta a pergunta - em quantidade de comment letters.

\section{Figura 3 - Nível de Concordância/Discordância das Perguntas Introdutórias}

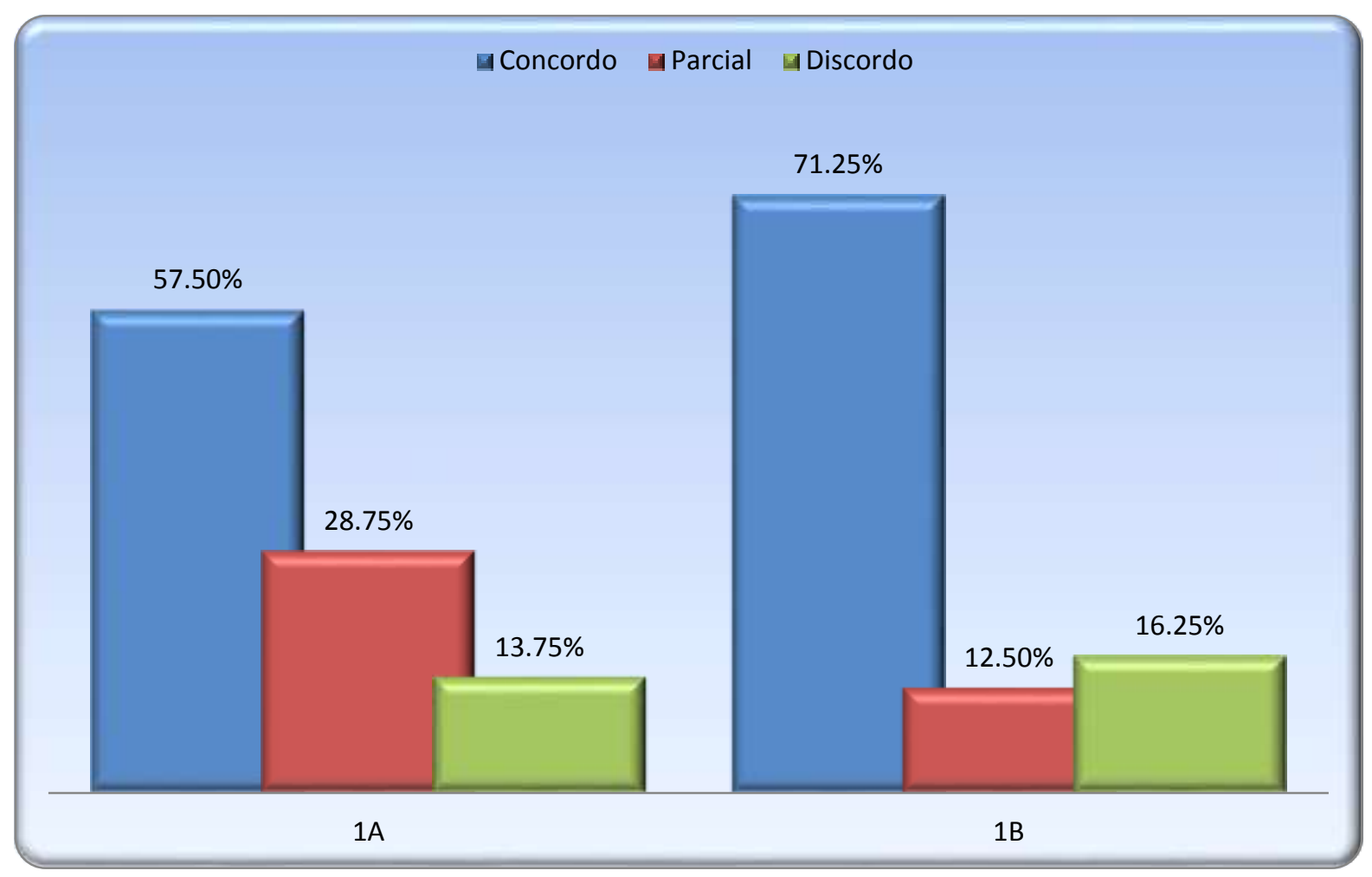

Fonte: Dados da Pesquisa

${ }^{22}$ Os parágrafos de 1.25 - 1.33 do DP/2013/1 estabelecem a proposta pretendida e o status da Estrutura Conceitual. As visões preliminares do IASB são que: a) o propósito primário da Estrutura Conceitual revisada é auxiliar a IASB a identificar conceitos que irá usar consistentemente ao desenvolver e revisar IFRSs; e, b) em casos raros, a fim de cumprir o objetivo global de relatórios contábeis, o IASB pode decidir emitir uma Norma, nova ou revisada, que entra em conflito com algum aspecto da Estrutura Conceitual. Em tais casos, o IASB descreverá o distanciamento da Estrutura Conceitual, e as razões para isso, nas Bases para Conclusões daquela Norma. O IASB pergunta: Você concorda com essas visões preliminares? Por que ou por que não? 
A maioria das cartas - individualmente analisadas - apresentou comportamento similar em relação às duas perguntas, sendo o nível de concordância de 57,5 e 71,25 pontos percentuais para as perguntas $1 \mathrm{~A}$ e $1 \mathrm{~B}$, respectivamente. $\mathrm{O}$ nível de discordância perfaz um total de 13,75 e 16,25 pontos percentuais, para as mesmas questões.

Com a intenção de melhor interpretar os dados supracitados, foi calculado o índice de concordância $^{23}$, o qual solidifica numericamente as variações das opiniões, para efeito de comparação entre as questões analisadas. Percebe-se através da Tabela 5, que o Índice de concordância - relação entre concordância e discordância total ou parcial - é relativamente alto, principalmente na questão $1 \mathrm{~B}$, onde, para cada resposta em que o respondente concordava parcialmente ou discordava, outros 2,48 respondentes, concordavam.

Tabela 5 - Índice de Concordância/Discordância - Introdução

\begin{tabular}{lccc}
\hline & $\mathbf{1 A}$ & $\mathbf{1 B}$ & Total \\
\hline \hline Concordo & 46 & 57 & 103 \\
\hline Discordo & 11 & 13 & 24 \\
\hline Parcial & 23 & 10 & 33 \\
\hline Índice & $\mathbf{1 , 3 5}$ & $\mathbf{2 , 4 8}$ & $\mathbf{1 , 8 1}$ \\
\hline Fonte: Dados da Pesquisa, adaptado de Matos (2013) &
\end{tabular}

Segundo o IASB (2014a), os usuários, em geral, não têm muitas perguntas ou comentários sobre a finalidade e status da Estrutura Conceitual. Todas as perguntas funcionavam como esclarecimentos sobre o processo que resultará em padrões atualizados, como, por exemplo, quando e como as mudanças na Estrutura Conceitual afetarão os padrões individuais. Alguns sugeriram que o status do Quadro Conceptual, como a fundação de normas, resulte na possibilidade de ser ele referido por muitos componentes, incluindo usuários, preparadores, auditores e acadêmicos.

Em relação à pergunta $1 \mathrm{~A}$, a título de exemplo, vários respondentes citaram que o propósito primário da Estrutura Conceitual não deveria ser apenas “...auxiliar o IASB...”, tendo em vista que outros usuários a utilizam para os seus devidos fins ${ }^{24}$. Aqueles que assim

\footnotetext{
23 Índice de Concordância/Discordância = Número de respostas em que o respondente concorda com a proposta, dividido pelo número de respostas em que o respondente discordava, seja na totalidade ou em quaisquer aspectos da proposta.

${ }^{24}$ De acordo com IASB (2014b, p. 2) em 24 de Abril de 2014 foi discutida a proposta e o status da Estrutura Conceitual. Foi decidido que: o objetivo da Estrutura Conceitual deve ser identificar os conceitos que:

(i) auxiliam o IASB para desenvolver e revisar as normas;

(ii) ajudam os preparadores para desenvolver políticas contabilísticas quando nenhuma Norma aplica-se a uma transação particular, evento ou condição;

(iii) ajudam todas as partes a compreender e interpretar as normas.
} 
justificavam, discordaram, concordaram parcialmente com a proposta e, até mesmo, alguns concordaram com a proposta, mas sugeriram que a finalidade principal pudesse ser mudada para englobar todos os demais usuários. Quanto à questão $1 \mathrm{~B}$ os principais pressupostos dos respondentes partiram daqueles que não concordavam ou concordavam parcialmente, pois argumentaram que não deveria haver distanciamento entre a Estrutura Conceitual e as demais Normas - novas ou revisadas.

O IASB (2014a) ressalta que alguns outros respondentes sugeriram que a Estrutura Conceitual é percebida por muitos como sendo semelhante à orientação comportamental. Eles observaram que os conceitos de stewardship, reliability e prudence são particularmente importantes como orientação comportamental. Alguns sugeriram que a Estrutura Conceitual deve estabelecer uma base sólida de conceitos básicos para se defender contra as interpretações pobres ou enfraquecimento de Normas.

\subsubsection{Elementos de Relatórios Financeiros}

A seção Elementos de Relatórios Financeiros é composta por 6 (seis) questões ${ }^{25}: 2 \mathrm{~A}$, 2B, 2C, 3A, 3B e 3C. As questões 2A, 2B e 2C, expõem a discussão acerca das definições de Ativo, Passivo e Recurso Econômico. Já as perguntas 3A, 3B e 3C complementam aquelas, destacando a questão da Incerteza - se ela deve desempenhar qualquer papel nas definições e, critérios para reconhecimento de ativos e passivos.

De forma geral, evidencia-se alto nível de concordância por parte dos respondentes. A Figura 4 destaca uma ampla aceitação dos usuários quanto às definições propostas para Ativo, Passivo e Recurso Econômico atingindo 70,00, 73,75 e 75,00 pontos percentuais, respectivamente, em relação às definições. A questão 3A auferiu o maior percentual de aceitação da seção, isto é, 76,25 e a pergunta 3C, o maior percentual de discordância, 36,25.

\footnotetext{
${ }^{25}$ Q2. As definições de ativos e passivos são discutidas nos parágrafos 2.6-2.16 do DP/2013/1. O IASB propõe as seguintes definições: (a) um ativo é um recurso econômico presente controlado pela entidade como resultado de eventos passados; (b) Um passivo é uma obrigação presente da entidade de transferir um recurso econômico como um resultado de eventos passados; (c) um recurso econômico é um direito, ou outra fonte de valor, que é capaz de produzir benefícios econômicos. O IASB pergunta: Você concorda com essas visões preliminares? Por que ou por que não? Se você não concorda, que mudanças você sugere, e por quê?

Q3. A visão preliminar do IASB é que: (a) as definições de ativos e passivos não devem reter a noção de que uma entrada ou saída é 'esperada'. Um ativo deve ser capaz de produzir benefícios econômicos. O passivo deve ser capaz de resultar em uma transferência de recursos econômicos; (b) a Estrutura Conceitual não deve definir um limite de probabilidade para os raros casos em que é incerto se um ativo ou um passivo existe. Se pudesse haver incerteza significativa sobre se um determinado tipo de ativo ou passivo existe, o IASB decidiria como lidar com essa incerteza quando se desenvolve ou revisa um padrão nesse tipo de ativo ou passivo; (c) os critérios de reconhecimento não devem manter a referência existente à probabilidade. O IASB pergunta: Você concorda? Por que ou por que não? Se você não concorda, o que você sugere, e por quê?
} 
A Tabela 6 revela o índice de concordância desta seção. A pergunta com maior resultado foi a 3A e para cada discordância ou concordância parcial, obteve-se 3,21 concordâncias. A pergunta com menor indicador foi a 3C, sendo que para cada discordância ou concordância parcial, obteve-se 1,16 concordâncias.

Segundo o IASB (2014a), muitos respondentes apoiaram a melhoria das definições, sendo que alguns sugeriram que o IASB defina lucro líquido, lucros e perdas e outros resultados abrangentes, além de receitas e despesas. Eles sugeriram que a definição do lucro líquido como a diferença entre receita e despesa seja consistente com a definição de patrimônio como a diferença entre ativos e passivos. No entanto, houve opiniões divergentes sobre a remoção de qualquer referência à expectativa ou probabilidade de ambas as definições e critérios de reconhecimento. Alguns usuários observaram que a remoção do limite de probabilidade dos critérios de reconhecimento ou da definição de um ativo pode torná-los muito amplo, enquanto outros apoiaram, esclarecendo que os itens devem ser reconhecidos independentemente de incerteza. Outros não tinham certeza se o IASB destina as novas definições, para implicar um limite de probabilidade. Alguns, por fim, pediram mais divulgação sobre os ativos intangíveis gerados internamente, reconhecidos ou não.

Figura 4 - Nível de Concordância/Discordância das Perguntas sobre Elementos dos Relatórios Financeiros

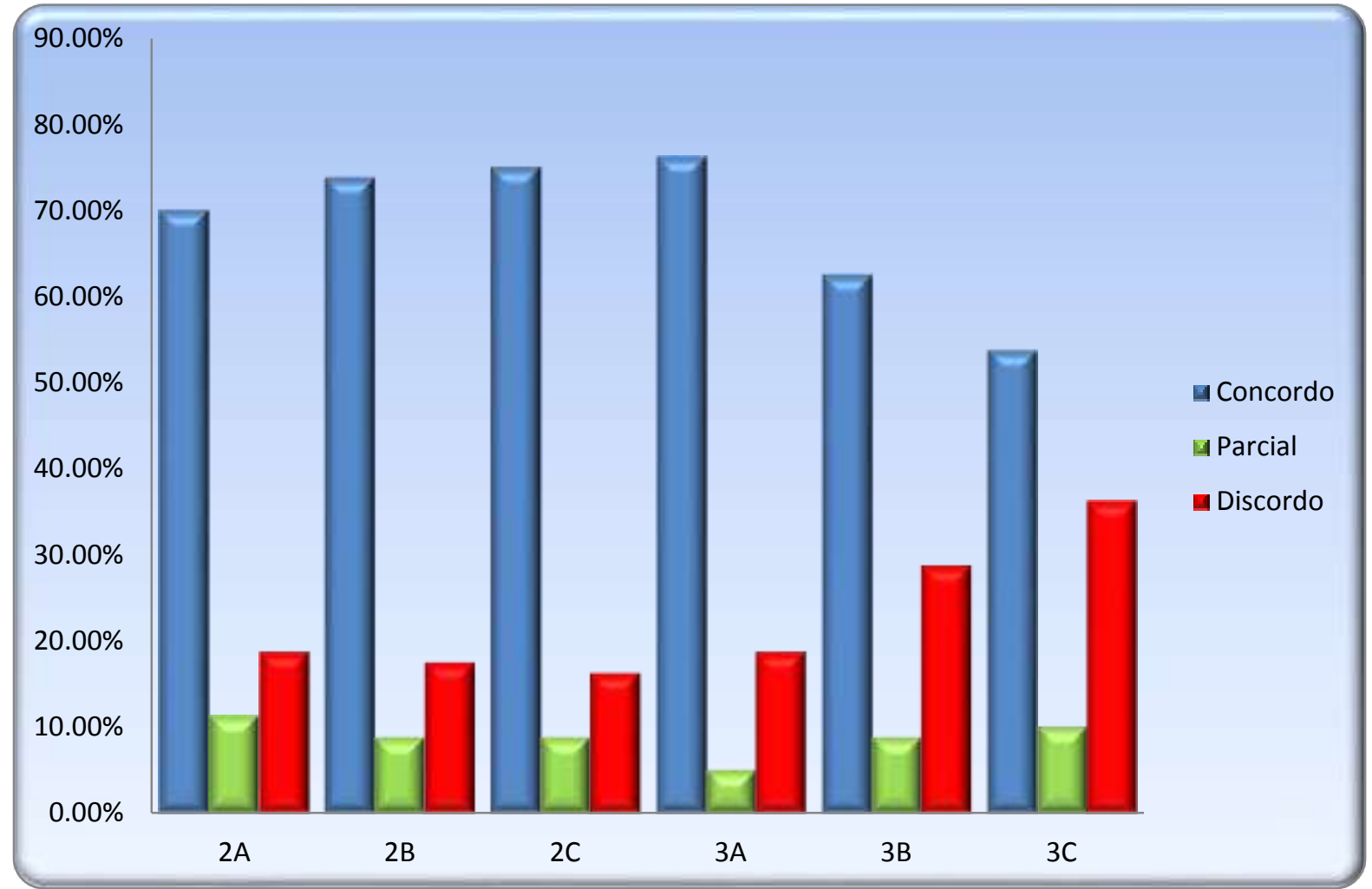

Fonte: Dados da Pesquisa 
Tabela 6 - Índice de Concordância/Discordância - Elementos dos Relatórios Financeiros

\begin{tabular}{lccccccc}
\hline & $\mathbf{2 A}$ & $\mathbf{2 B}$ & $\mathbf{2 C}$ & $\mathbf{3 A}$ & $\mathbf{3 B}$ & $\mathbf{3 C}$ & Total \\
\hline \hline Concordo & 56 & 59 & 60 & 61 & 50 & 43 & 329 \\
\hline Discordo & 15 & 14 & 13 & 15 & 23 & 29 & 109 \\
\hline Parcial & 9 & 7 & 7 & 4 & 7 & 8 & 42 \\
\hline Índice & $\mathbf{2 , 3 3}$ & $\mathbf{2 , 8 1}$ & $\mathbf{3 , 0 0}$ & $\mathbf{3 , 2 1}$ & $\mathbf{1 , 6 7}$ & $\mathbf{1 , 1 6}$ & $\mathbf{2 , 1 8}$ \\
\hline
\end{tabular}

Fonte: Dados da Pesquisa

Em relação aos setores de atuação, os que mais concordaram foram os preparadores, seguidos da academia, respectivamente com 74,56 e 71,43 pontos percentuais. Por outro lado, os reguladores foram os que mais discordaram, seguidos pelos normatizadores, sendo, 33,33 e 24,24 pontos percentuais, respectivamente. Essa conjuntura pode ser justificada pela própria essência das definições propostas, tendo em vista que permitirão maior flexibilidade e julgamento profissional por parte principalmente dos preparadores, no tocante aos itens que se amoldam as definições de ativo, passivo e recurso econômico. Tal elasticidade da definição permitirá que um número maior de ativos sejam reconhecidos nos relatórios financeiras.

Por sua vez, a maior discordância ocorrendo por parte dos Reguladores pode ser explicada pela pressão do mercado de capitais e pela preocupação para com os investidores e a salvaguarda desses. Maior flexibilidade possibilitaria maiores oportunidades para gerenciamento de resultados, principalmente nos países em que a origem do sistema contábil foi baseada no modelo code low (LEUZ, NANDA; WYSOCKI, 2003; KLANN; BEUREN, 2010).

\subsubsection{Orientação Adicional de Apoio as Definições de Ativo e Passivo}

Duas questões fazem parte desta seção, $5^{26}$ e $6^{27}$, as quais seguem o mesmo comportamento, atingindo alto nível de concordância conforme Figura 5. A pergunta 5

\footnotetext{
26 A discussão considera que a possibilidade de se estreitar a definição de um passivo para incluir apenas obrigações que são asseguráveis por lei ou outro meio equivalente. Porém, o IASB, provisoriamente, favorece a retenção das definições existentes, que englobam ambas as obrigações legais e construtivas - e a adição de mais orientações para ajudar a distinção da obrigação construtiva da compulsão econômica. O IASB pergunta: Você concorda com essa visão preliminar? Por que ou por que não?

${ }^{27}$ Uma obrigação presente surge de eventos passados. Uma obrigação pode ser vista como tendo surgida de eventos passados se a quantia do passivo for ser determinada por referência aos benefícios recebidos, ou atividades conduzidas, pela entidade antes do fim do período de registro. Entretanto, não é claro se tais eventos passados são suficientes para criar uma obrigação presente se nenhum requisito de transferência de recursos econômicos permanecerem condicionais às ações futuras da entidade. Três visões diferentes sobre as quais o IASB poderia desenvolver orientações para a Estrutura Conceitual são dispostas a seguir: Visão 1: uma obrigação presente deve originar de eventos passados e ser estritamente incondicional. Uma entidade não tem uma obrigação presente se pudesse, pelo menos em teoria, evitar a transferência por meio de suas ações futuras.
} 
destaca a manutenção da definição de Passivo, incluindo obrigações legais e obrigações construtivas, para a qual obteve-se 87,5 pontos percentuais de concordância. Já a pergunta 6 descreve a proposta do IASB para obrigação presente, onde são apresentadas 3 visões distintas para sua definição. Notadamente, alcançou 81,25 pontos percentuais de concordância.

No que tange às três visões acerca da definição do termo obrigação presente, o IASB é favorável as visões 2 e 3. Quando analisadas as preferências dos respondentes em relação a estas visões, a Figura 6 certifica que $70 \%$ dos respondentes preferem a visão $2^{28}$ e $20 \%$ elegem a visão $3^{29}$. Apenas $2 \%$ escolhem a visão 1 e $8 \%$ é desfavorável a qualquer delas.

Figura 5 - Nível de Concordância/Discordância das Perguntas sobre Orientação de Apoio as Definições de Ativo e Passivo

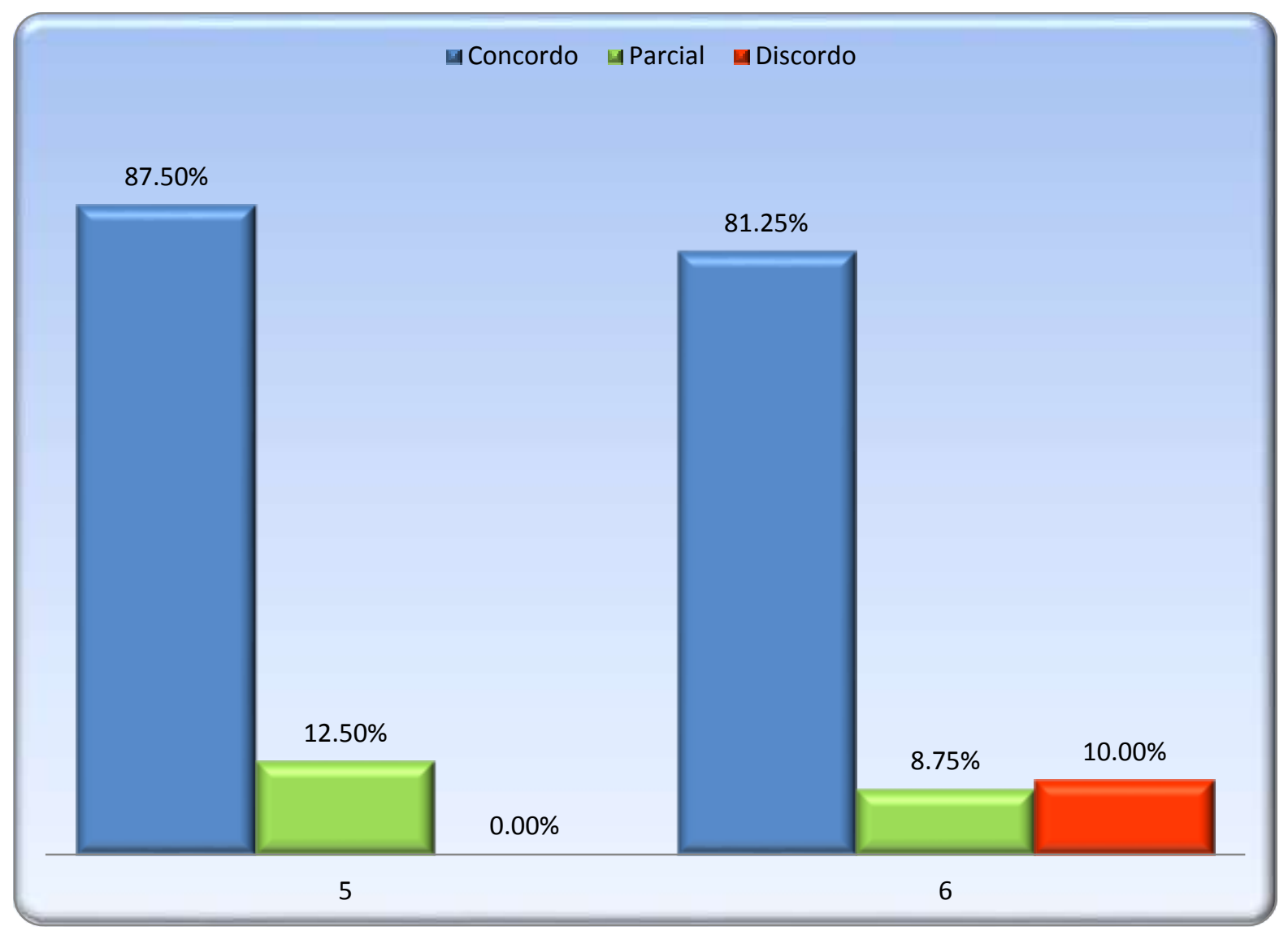

Fonte: Dados da Pesquisa

Visão 2: uma obrigação presente deve originar de eventos passados e ser praticamente incondicional. Uma obrigação é praticamente incondicional se a entidade não tem capacidade prática para evitar a transferência por meio de suas ações futuras. Visão 3: uma obrigação presente deve originar de eventos passados, mas pode ser condicional em ações futuras da entidade. O IASB tem, provisoriamente, rejeitado a Visão 1. Porém, ele ainda não chegou a uma visão preliminar em favor da Visão 2 ou da Visão 3. Qual dessas visões (ou qualquer outra visão sobre quando uma obrigação presente passa a existir) você apoia?

${ }^{28}$ Entre os respondentes que preferem a visão 2, um total de 4 (quatro) também são favoráveis a visão 3.

${ }^{29}$ Entre os respondentes que preferem a visão 3, um deles também é favorável a visão 1. 
Segundo o IASB (2014a), a maioria dos usuários prefere a Visão 2 ou a Visão 3, em detrimento da Visão 1. Alguns usuários expressaram uma visão de que o IASB deve adotar uma abordagem apropriada para alguns itens, em vez de definir os ativos e passivos por referência aos direitos e obrigações. Na opinião deles, a Visão 1 (estritamente incondicional) concentra-se muito sobre a situação jurídica e não fornece informações sobre os custos reais que surgiram no período.

À medida que o IASB provisoriamente rejeita a Visão 1, afirmando que não considera que uma entidade deveria omitir, de suas demonstrações financeiras, passivos que surgiram de eventos passados e que a entidade não possui capacidade prática de evitar, sendo que, ao fazer isso, excluiriam informação relevante sobre o futuro inevitável de custos das ações passadas da entidade, ele, possivelmente estaria induzindo os respondentes a escolherem entre a Visão 2 ou 3, fato que justificaria a preferência dos respondentes por essas visões.

Figura 6 - Opinião dos respondentes em relação às visões acerca da definição de Obrigação Presente

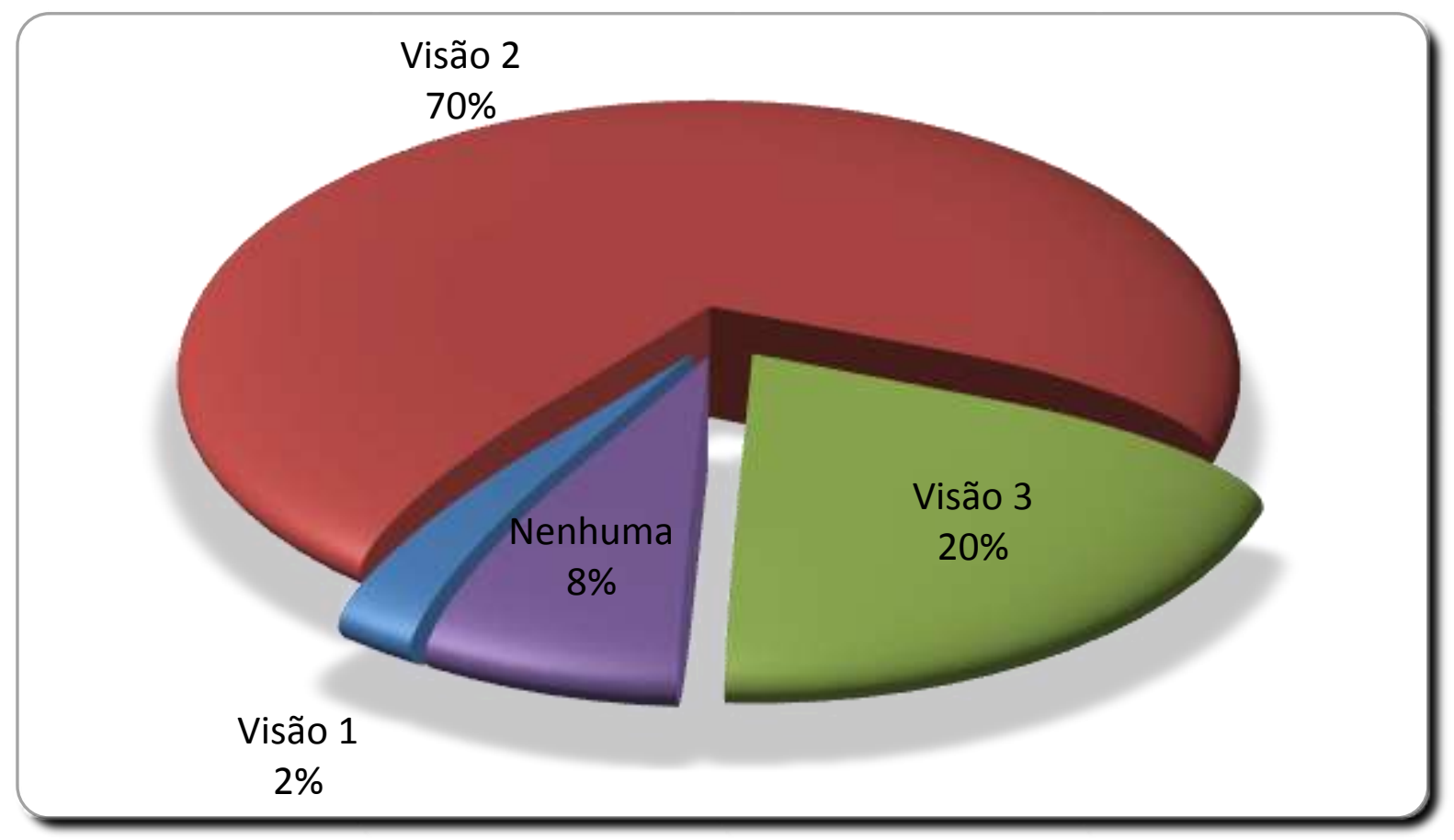

Fonte: Dados da Pesquisa

Para melhor entendimento da superioridade das respostas favoráveis em relação às desfavoráveis e parciais, foi calculado o índice de concordância, evidenciado na tabela 7 , ratificando o elevado índice de concordância por perguntas, atingindo 7 respostas favoráveis para cada desfavorável ou parcial em relação à questão 5, isto é, para cada respondente que 
não concordou ou que concordou parcialmente, sete concordaram totalmente e 4,33 respostas favoráveis para cada resposta desfavorável ou parcial em referência a questão 6, ou seja, enquanto um discordou ou concordou parcialmente, 4,33 concordaram.

Tabela 7 - Índice de Concordância/Discordância - Orientação Adicional de Apoio as Definições de Ativo e Passivo

\begin{tabular}{lccc}
\hline & $\mathbf{5}$ & $\mathbf{6}$ & Total \\
\hline \hline Concordo & 70 & 65 & 135 \\
\hline Discordo & 0 & 8 & 8 \\
\hline Parcial & 10 & 7 & 17 \\
\hline Índice & $\mathbf{7 , 0 0}$ & $\mathbf{4 , 3 3}$ & $\mathbf{5 , 4 0}$ \\
\hline
\end{tabular}

Fonte: Dados da Pesquisa

Concernente à análise por setor de atuação, os preparadores foram aqueles que mais concordaram com esta seção, atingindo 92,11\%, seguidos por associação profissional com 90,00\%. Já os reguladores são responsáveis pelo maior nível de discordância, auferindo $33,33 \%$.

Maior flexibilidade na definição de Passivo resultando em normas também mais flexíveis - no que concerne às normas relacionadas a esse elemento. Normas mais flexíveis, apesar das dificuldades na elaboração dos relatórios financeiros, principalmente no que tange ao julgamento profissional e a devida adaptação dos profissionais para tal, contribui mais satisfatoriamente para a demonstração da realidade econômica da companhia. Além disso, a cultura de cada país, influencia nas normas contábeis e, portanto, normas mais flexíveis permitirão melhor adaptação das IFRSs no contexto socioeconômico de cada um. Esses fatores fundamentam o nível de concordância por parte dos preparadores.

\subsubsection{Reconhecimento e Desreconhecimento}

Três foram as perguntas sobre reconhecimento e desreconhecimento, $8 \mathrm{~A}, 8 \mathrm{~B}^{30}$ e 9 . As questões $8 \mathrm{~A}$ e $8 \mathrm{~B}$ referem-se à afirmativa do IASB sobre o dever da entidade em reconhecer todos os seus Ativos e Passivos, a não ser que a informação não seja relevante ou não

\footnotetext{
30 8. Na visão preliminar do IASB, uma entidade deve reconhecer todos os seus ativos e passivos, a não ser que o IASB decida, ao desenvolver ou revisar uma Norma específica, que uma entidade não precisa, ou não deve, reconhecer um ativo ou passivo por que: a) reconhecer o ativo (ou passivo) forneceria aos usuários das demonstrações financeiras uma informação que é irrelevante, ou insuficientemente relevante para justificar o custo; ou, b) nenhuma mensuração do ativo (ou passivo) resultará em uma representação fiel tanto do ativo (ou passivo) e das mudanças no ativo (ou passivo), mesmo se todas as descrições e explicações necessárias forem divulgadas. Você concorda? Por que ou por que não?
} 
represente fielmente o que se propõe a representar. Já a pergunta $9^{31}$ refere-se ao desreconhecimento - quando ele deve ocorre - e seus aspectos relevantes, na qual são apresentadas duas abordagens: abordagem de controle e abordagem de riscos e recompensas ${ }^{32}$. Entretanto, o IASB é favorável à abordagem do controle.

A Figura 7 destaca o comportamento dos respondentes em relação a essas questões, demonstrando similaridade entre as respostas, atingindo, respectivamente 60,00, 58,75 e 58,75 pontos percentuais em relação à concordância. Quanto à discordância, os níveis alcançados foram $28,75,26,25$ e 30,00 pontos percentuais.

Figura 7 - Nível de Concordância/Discordância das Perguntas sobre Reconhecimento e Desreconhecimento

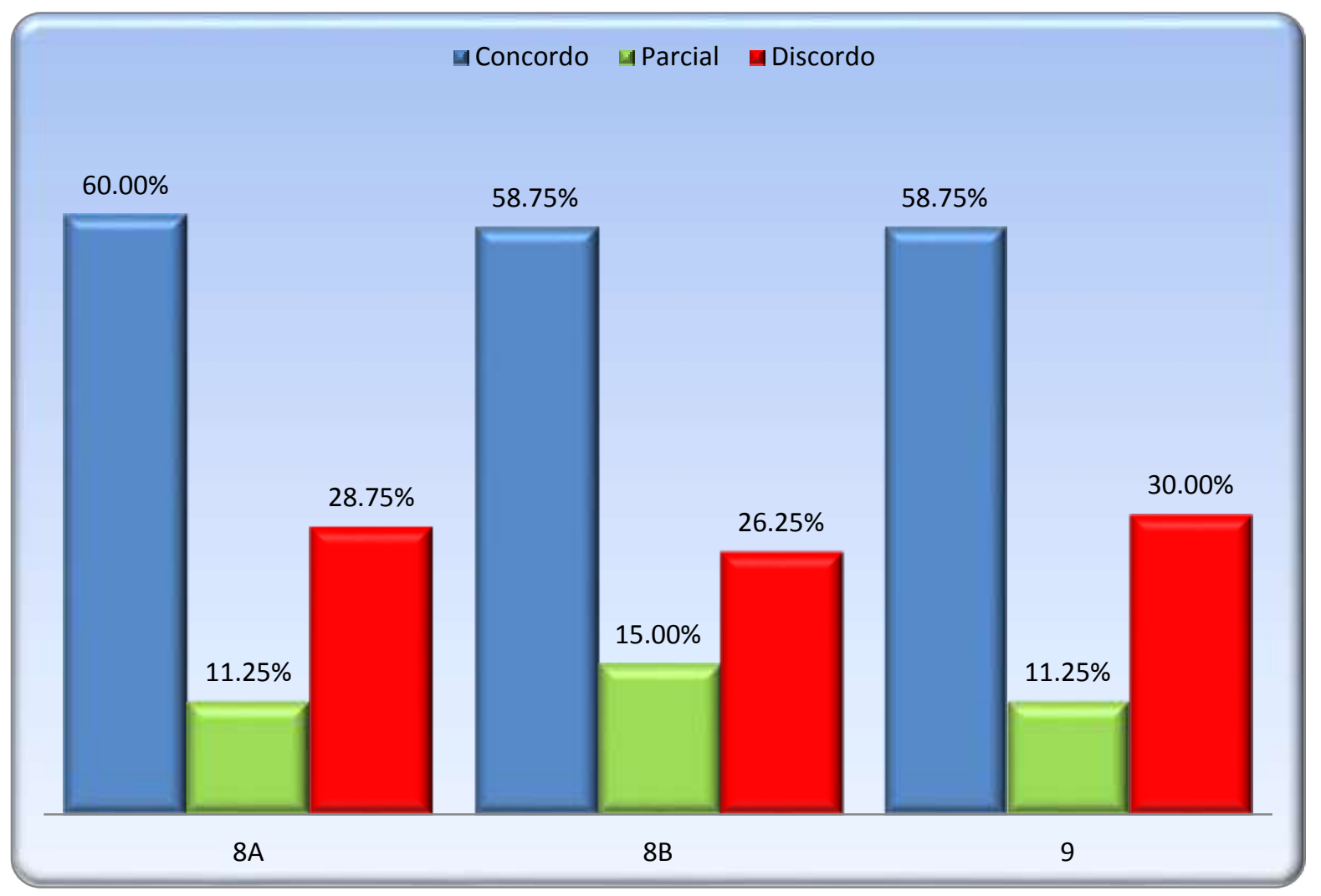

Fonte: Dados da Pesquisa

\footnotetext{
31 9. Na visão preliminar do IASB, uma entidade deve desreconhecer um ativo ou passivo quando ele deixar de atender aos critérios de definição (Abordagem de controle). Contudo, se uma entidade retiver um componente ou passivo, o IASB deve determinar, ao desenvolver ou revisar uma Norma específica, como a entidade melhor retrataria as mudanças resultantes da transação. As abordagens possíveis incluem: a) divulgação aprimorada; b) apresentar novos direitos ou obrigações retidos em um item que difere do item que foi usado pelos direitos ou obrigações originais, para destacar a maior concentração de risco; ou, c) continuar a reconhecer o ativo ou passivo original e tratar os rendimentos recebidos ou pagos pela transação como um empréstimo recebido ou concedido. O IASB tem, provisoriamente, rejeitado a Visão 1. Porém, ele ainda não chegou a uma visão preliminar em favor da Visão 2 ou da Visão 3.

${ }^{32}$ As abordagens de Controle e Riscos e Recompensas são explicadas em detalhes na fundamentação.
} 
Ratificando a afirmativa anterior, quanto ao comportamento dos usuários, a Tabela 8 demonstra a similaridade das respostas, através do Índice de concordância das questões analisadas na seção. Os valores atingidos por esse indicador em cada uma das questões, não se difere substancialmente das demais, sendo que, a título de exemplo, as questões 8B e 9 auferiram a mesma importância.

Tabela 8 - Índice de Concordância/Discordância - Reconhecimento e Desreconhecimento

\begin{tabular}{lcccc}
\hline & $\mathbf{8 A}$ & $\mathbf{8 B}$ & $\mathbf{9}$ & Total \\
\hline \hline Concordo & 48 & 47 & 47 & 142 \\
\hline Discordo & 23 & 21 & 24 & 68 \\
\hline Parcial & 9 & 12 & 9 & 30 \\
\hline Índice & $\mathbf{1 , 5 0}$ & $\mathbf{1 , 4 2}$ & $\mathbf{1 , 4 2}$ & $\mathbf{1 , 4 5}$ \\
\hline
\end{tabular}

Fonte: Dados da Pesquisa

No que tange aos setores de atuação, os auditores foram os que mais concordaram, sendo $75 \%$ o nível de concordância desse setor. Em segundo lugar, com 66,67\%, figuram os reguladores. Os maiores discordantes foram os normatizadores e reguladores, com 39,39\% e $33,33 \%$ respectivamente. Esses resultados são fundamentados pelas explanações propiciadas pelo IASB no tocante ao reconhecimento e desreconhecimento. Os auditores, em linhas gerais, priorizam normas claras, em detrimento de outras formas de elaboração, de forma que possam embasar suas decisões e seus relatórios, e, além do mais, se salvaguardar de quaisquer adversidades envolvendo questões contábeis.

\subsubsection{Definição de PL e Distinção de Passivo e Instrumento de Capital}

A seção 5, Definição de Patrimônio Líquido e Distinção de Passivo e Instrumento de Capital é composta por 4 perguntas $^{33}$ : 10A, 10B, 10C e 10D. De maneira geral, a maioria dos

\footnotetext{
${ }^{33} \mathrm{Na}$ visão preliminar do IASB:

a) a Estrutura Conceitual deve manter a atual definição de capital como o interesse residual nos ativos da entidade após a dedução de todos os seus passivos.

b) a Estrutura Conceitual deve indicar que o IASB deve usar a definição de passivo para distinguir passivos de instrumentos de capital. Duas consequências disso são as seguintes: i) obrigações para emitir instrumentos de capital não são passivos, e, ii) obrigações que irão surgir apenas quando a entidade que relata for liquidada são não passivos.

c) uma entidade deve: i) atualizar a medida de cada classe de reivindicação de equivalência patrimonial no final de cada período de relato. O IASB determinaria quando desenvolver ou revisar Normas em especial se seria uma medida direta ou uma alocação do capital total. ii) reconhecer atualizações para essas mensurações na demonstração de alterações no capital, como uma transferência de riqueza entre as classes de reivindicação de equivalência patrimonial.
} 
respondentes concorda. Porém, analisando cada assertiva isoladamente, conforme a Figura 8 evidencia-se a dissimilitude entre as resposta dessas perguntas. A título de exemplo, a pergunta $10 \mathrm{~A}$ obteve $81,25 \%$ de concordância e a pergunta $10 \mathrm{~B}, 68,75 \%$. A maioria dos usuários concorda com a manutenção da atual definição de capital, possivelmente devido a praticidade no que concerne a utilização da definição e sua devida aplicação e que a definição de passivo é útil para distinguir passivo de instrumento de capital. Em relação as demais perguntas, o nível de discordância superou o de concordância e opiniões parciais, possivelmente devido falta de orientação adicional, conforme é solicitada pelos respondentes e pela complexidade da proposta, o poderia fomentar a reclassificação de instrumentos de dívida no patrimônio líquido.

Figura 8 - Nível de Concordância/Discordância das Perguntas sobre Definição de PL e Distinção de Passivo e Instrumento de Capital

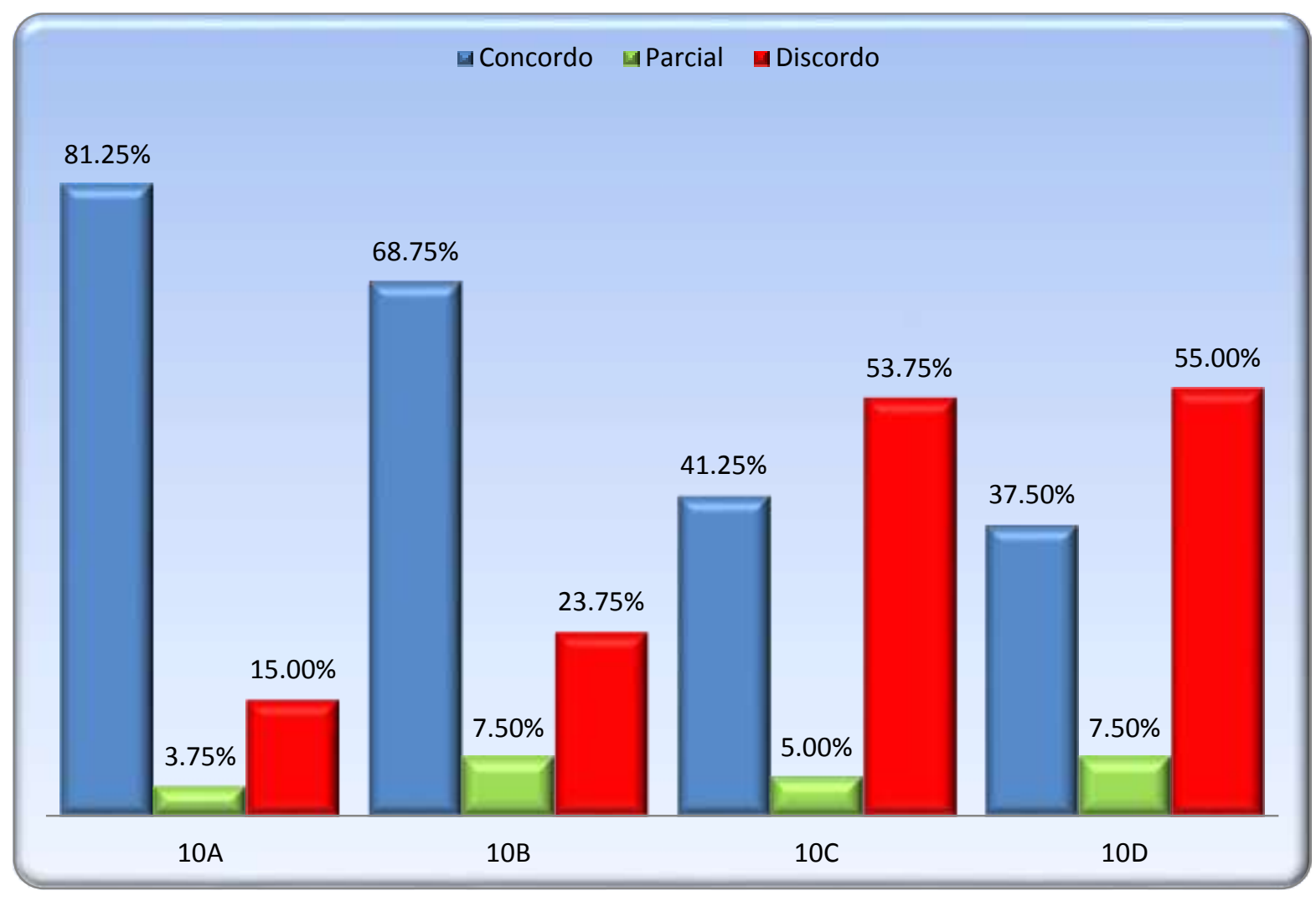

Fonte: Dados da Pesquisa

d) Se uma entidade não emitiu instrumentos de capital, pode ser apropriado tratar a mais subordinada classe de instrumentos como se fosse uma reivindicação de equivalência patrimonial, com adequada divulgação. Identificar se é o caso de usar tal abordagem e, em caso afirmativo, quando, seria uma decisão que o IASB precisaria fazer quando se desenvolve ou revisa Normas particulares.

O IASB pergunta: Você concorda? Por que ou por que não? 
Conforme o IASB (2014a), de maneira geral, os usuários aceitam que a atual distinção entre passivo e patrimônio líquido, conforme implementado nas Normas existentes, é problemática $^{34}$. No entanto, os usuários com foco em serviços financeiros ou em jurisdições, em que as entidades emitem regularmente títulos complexos, eram mais conscientes dos problemas nessa área do que outros. Os respondentes expressaram opiniões contraditórias sobre a "strict obligation approach" e a "narrow equity approach". Enquanto acolheram uma maior consistência nas Normas, eles queriam entender o efeito sobre os resultados contábeis. Eles expressaram preocupação com a strict obligation approach, que pode resultar em muitos instrumentos sendo reclassificados no patrimônio líquido.

Alguns participantes solicitaram estudos de campo sobre as propostas, para ajudar a entender os efeitos. Alguns usuários, incluindo muitos analistas financeiros, analistas de crédito e investidores, preferiram a "strict obligation approach". Outros expressaram preocupações sobre o tratamento de uma obrigação de emitir um número variável de ações próprias a um valor especificado. Existem ainda aqueles que expressaram preocupações sobre o tratamento de uma obrigação de emitir um número variável de ações próprias a um valor especificado. Quase todos os usuários eram favoráveis em exigir que as entidades fornecessem mais informações sobre os diferentes tipos de reivindicações. No entanto, houve opiniões divergentes sobre a forma e o conteúdo das informações. Alguns outros não suportaram a ideia de que a alegação mais residual deveria ser tratada como se fosse capital próprio se nenhuma reivindicação atende à definição de patrimônio líquido. No entanto, isto não foi discutido em detalhe.

Os fatos acima são corroborados pelo Índice de Concordância apresentado na Tabela 9. Esse indicador variou desde 0,60 (para cada resposta em que o respondente discordou ou concordou parcialmente, apenas 0,6 concordou) na pergunta 10D, até 4,33 (para cada resposta a qual o respondente discordou ou concordou parcialmente, 4,33 concordaram) na pergunta

\footnotetext{
${ }^{34}$ De acordo com o IASB (2014a, p. 6) alguns usuários identificados os seguintes problemas com a contabilidade atual:

a) O efeito de diferentes classes de equivalência patrimonial sobre outras é difícil de entender. Usuários afirmaram que no momento eles não recebem informações suficientes sobre os diferentes tipos de reclamações (existentes e potenciais) sobre uma entidade que relata, incluindo potencial de diluição.

b) A distribuição dos riscos e retornos entre os detentores de direitos classificadas como capital próprio é difícil de compreender. Usuários pensam que a informação sobre os riscos e retornos de cada ação é muito importante. c) A capacidade da entidade de pagar dividendos é difícil de entender. O Patrimônio Líquido deve ser desagregado para mostrar itens como reservas distribuíveis, OCI acumulados e exigências de capital. Lucros retidos são quantidades fixas que não estão sujeitos a alterações, enquanto OCI acumulados são provisórios.

d) Inconsistências contábeis reduzem a utilidade dos índices comumente utilizados, tais como alavancagem e lucro por ação.

e) O reconhecimento nas mudanças dos lucros e perdas no valor justo dos derivativos sobre ações de uma entidade não é útil.
} 
10A, ratificando a variação das percepções dos respondentes em relação às questões dessa seção.

Tabela 9 - Índice de Concordância/Discordância - Definição de PL e Distinção de Passivo e Instrumento de Capital

\begin{tabular}{lccccc}
\hline & $\mathbf{1 0 A}$ & $\mathbf{1 0 B}$ & $\mathbf{1 0 C}$ & $\mathbf{1 0 D}$ & Total \\
\hline \hline Concordo & 65 & 55 & 33 & 30 & 183 \\
\hline Discordo & 12 & 19 & 43 & 44 & 118 \\
\hline Parcial & 3 & 6 & 4 & 6 & 19 \\
\hline Índice & $\mathbf{4 , 3 3}$ & $\mathbf{2 , 2 0}$ & $\mathbf{0 , 7 0}$ & $\mathbf{0 , 6 0}$ & $\mathbf{1 , 3 4}$ \\
\hline
\end{tabular}

Fonte: Dados da Pesquisa

A maioria dos preparadores (o que equivale a 67,11\%) concorda com as assertivas propostas na seção. Outro destaque são os reguladores com 66,67\% de concordância. Já em relação aos maiores discordantes, citam-se os grupos associação profissional e auditoria, com $43,75 \%$ e 40,63\%. Apesar das implicações citadas no que diz respeitos as abordagens "strict obligation approach" e a "narrow equity approach", no geral, possivelmente não serão encontradas maiores dificuldades na aplicação de Normas alinhadas, principalmente com a pergunta $10 \mathrm{~A}$ e $10 \mathrm{~B}$.

\subsubsection{Mensuração}

A seção 6 - Mensuração - é aquela com maior número de perguntas, sendo 11, 12, 13 e 14, fracionadas em 16 perguntas as quais tratam dos seguintes assuntos: a) como o objetivo da demonstração financeira e suas características da demonstração financeira útil afetam a mensuração $(11 \mathrm{~A}, 11 \mathrm{~B}, 11 \mathrm{C}, 11 \mathrm{D}, 11 \mathrm{E} \text { e } 11 \mathrm{~F})^{35}$; b) mensuração subsequente de ativos (12A,

${ }^{35}$ O IASB discute como o objetivo da demonstração financeira e suas características qualitativas da informação financeira útil afetam a mensuração. As visões preliminares do IASB são que:

a) o objetivo da mensuração é de contribuir para a representação fiel de informação relevante sobre: i) os recursos da entidade, reivindicações contra a entidade e mudanças nos recursos e reivindicações; e, ii) o quão eficientemente e eficazmente a administração e o conselho administrativo da empresa têm cumprido suas responsabilidades no uso dos recursos da entidade.

b) uma única base de mensuração para todos ativos e passivos pode não fornecer a informação mais relevante para os usuários das demonstrações financeiras.

c) ao selecionar a mensuração a utilizar para um item específico, o IASB deve considerar qual informação essa mensuração irá produzir tanto na demonstração de posição financeira quanto na demonstração de lucros ou perdas e OCI.

d) a seleção de uma mensuração: i) para um ativo específico deve depender de como esse ativo contribui para futuros fluxos de caixa; e, ii) para um passivo específico deve depender de como a entidade irá liquidar ou cumprir esse passivo. 
12B, 12C e 12D) ${ }^{36}$; c) mensuração subsequente de passivos $(13 \mathrm{~A}, 13 \mathrm{~B} \text { e } 13 \mathrm{C})^{37}$ e d) mensuração de ativos e passivos financeiros com base nos fluxos de caixa pode não ser informação útil (14A, 14B e 14C) $)^{38}$.

As Figuras 9A, 9B, 9C e 9D ilustram as opiniões expostas pelos respondentes, na qual são demonstradas expressivas variações entre as respostas, principalmente quando se avalia o menor percentual de concordância, pergunta 12D - 62,5\% - e o maior percentual de concordância, pergunta $11 \mathrm{~F}-91,25 \%$. O desvio padrão amostral calculado entre as respostas concordantes foi de 6,35 e o desvio médio equivalente a 4,98. Quando se analisa individualmente as subseções, mensuração subsequente de passivos (13A, 13B e 13C) e mensuração de ativos e passivos financeiros com base nos fluxos de caixa pode não ser

e) o número de mensurações diferentes usadas deve ser o menor número necessário para fornecer uma informação relevante. Mudanças desnecessárias de mensuração devem ser evitadas e as mudanças necessárias de mensuração devem ser explicadas.

f) os benefícios de uma mensuração específica para os usuários das demonstrações financeiras precisam ser suficientes para justificar o seu custo.

O IASB pergunta: Você concorda com essas visões preliminares? Por que ou por que não?

${ }^{36}$ As visões preliminares do IASB vistas na Questão 11 têm implicações para a mensuração subsequente de ativos. As visões preliminares do IASB são de que:

a) Se ativos contribuem indiretamente para os futuros fluxos de caixa através do uso ou são usados em combinação a outros ativos para gerar fluxos de caixa, mensurações baseadas em custo normalmente fornecem uma informação que é mais relevante e compreensível do que os preços de mercado atuais.

b) Se ativos contribuem para os futuros fluxos de caixa ao serem vendidos, um preço de saída atual é suscetível a ser relevante.

c) Se o ativo financeiro possui uma variabilidade insignificativa nos fluxos de caixa contratuais, e são mantidos para coleta, uma mensuração baseada em custo provavelmente fornecerá uma informação relevante.

d) Se uma entidade cobra pelo uso de ativos, a relevância de uma mensuração específica desses ativos dependerá da significância do ativo individual para entidade.

Você concorda com essas visões preliminares e a orientação proposta? Por que ou por que não?

${ }^{37}$ As visões preliminares do IASB quanto as implicações para a mensuração subsequente de passivos são que:

a) mensuração baseadas em fluxo de caixa são suscetíveis a ser a única mensuração viável para passivos sem termos apresentados.

b) uma mensuração baseada em custo irá, normalmente, fornecer a informação mais relevante sobre: i) passivos que serão liquidados de acordo com seus termos; e, ii) obrigações contratuais para serviços (obrigações de desempenho).

c) preços de mercado atuais provavelmente fornecerão a informação mais relevante sobre passivos que serão transferidos.

O IASB pergunta: Você concorda com essas visões preliminares e a orientação proposta? Por que ou por que não?

38 A visão preliminar do IASB é que para alguns ativos financeiros e passivos financeiros (por exemplo, derivativos), baseando a mensuração na maneira em que cada ativo contribui para os futuros fluxos de caixa, ou na maneira em que o passivo é liquidado ou cumprido, pode não fornecer informação que é útil ao avaliar as expectativas para futuros fluxos de caixa. Por exemplo, informação baseada em custo sobre ativos financeiros que são mantidos para coleta ou passivos financeiros que são liquidados de acordo com seus termos podem não fornecer informação que é útil ao avaliar as perspectivas para futuros fluxos de caixas:

a) se o fluxo de caixa definitivo não está proximamente ligado ao custo original;

b) se, devido à variabilidade significativa de fluxos de caixa contratuais, as técnicas de mensuração baseadas em custo podem não funcionar porque elas seriam incapazes de simplesmente alocar pagamentos de juros sobre a vida de tal ativo ou passivo financeiro; ou,

c) se mudanças nos fatores de mercado têm um efeito desproporcional no valor do ativo ou do passivo (isto é, o ativo ou passivo é altamente alavancado).

O IASB pergunta: Você concorda com essa visão? Por que ou por que não? 
informação útil (14A, 14B e 14C), percebe-se certa similaridade nas respostas, sendo o desvio padrão 1,15 e 0,58 respectivamente. Apesar dessas variações, de maneira geral percebe-se que a maioria concorda com a proposta no tocante a Mensuração.

Figura 9 - Nível de Concordância/Discordância das Perguntas sobre Mensuração

A - A forma com que o objetivo da demonstração financeira e suas características qualitativas afetam a mensuração

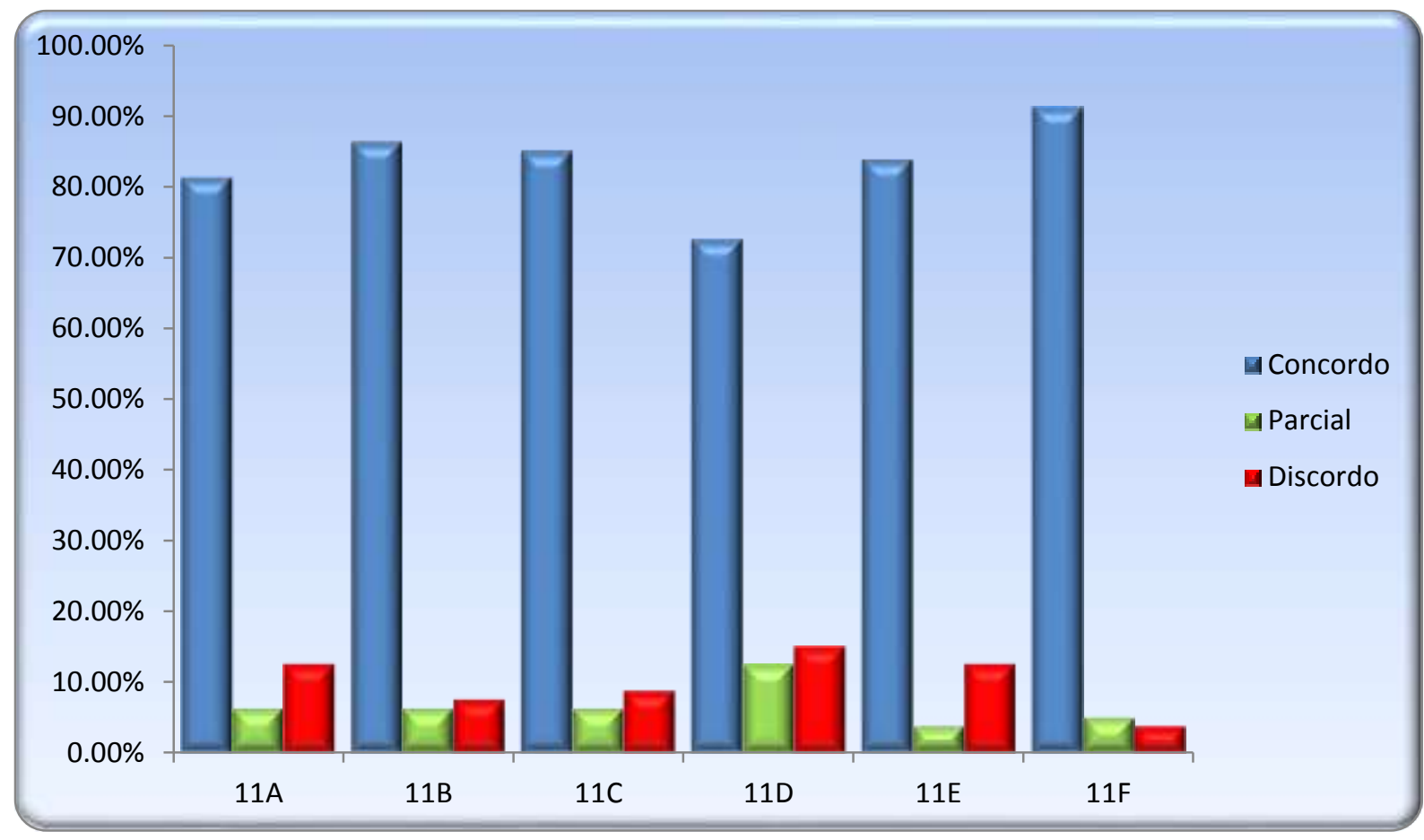

B - Mensuração subsequente de Ativos

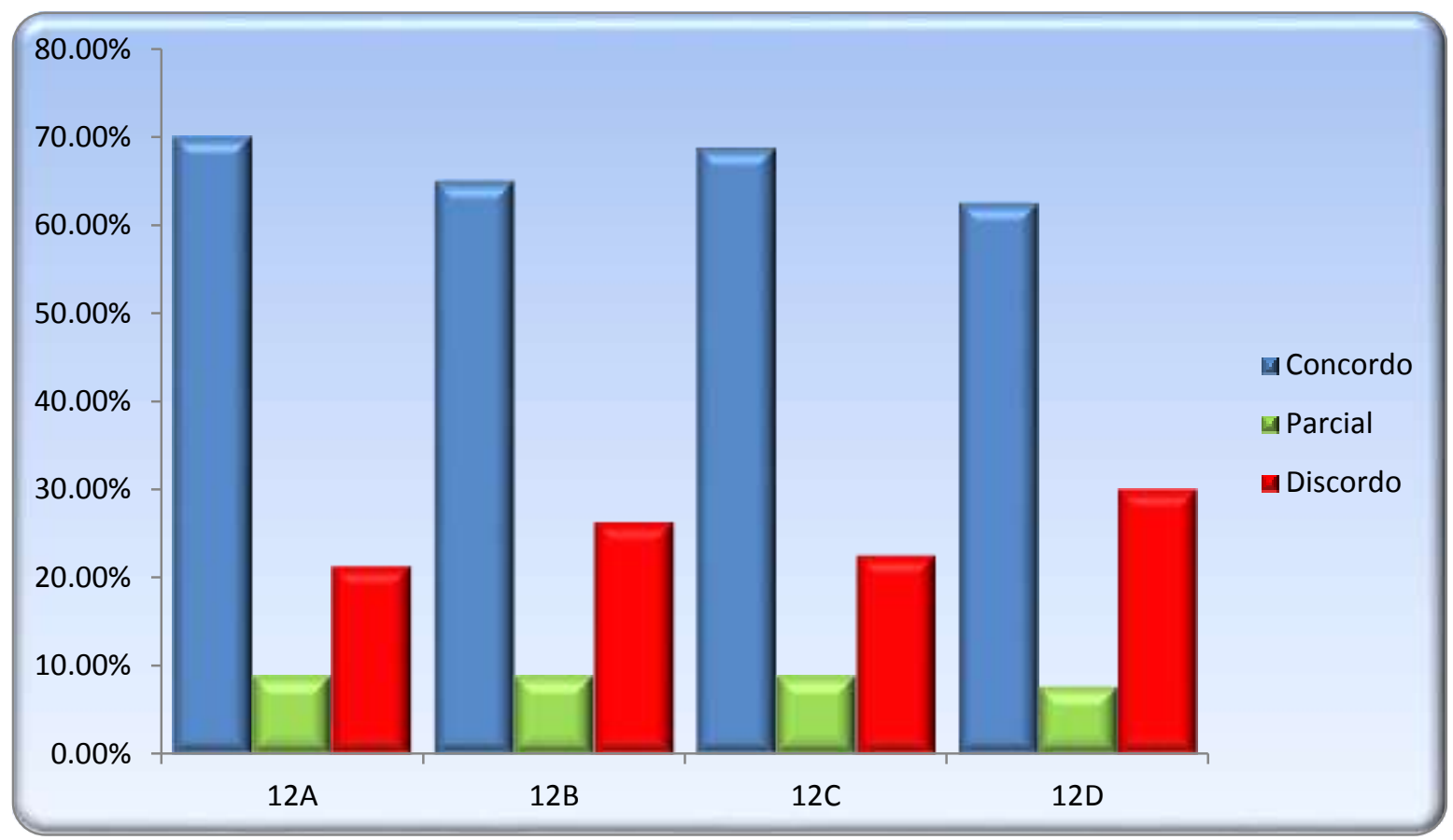


C - Mensuração subsequente de Passivos

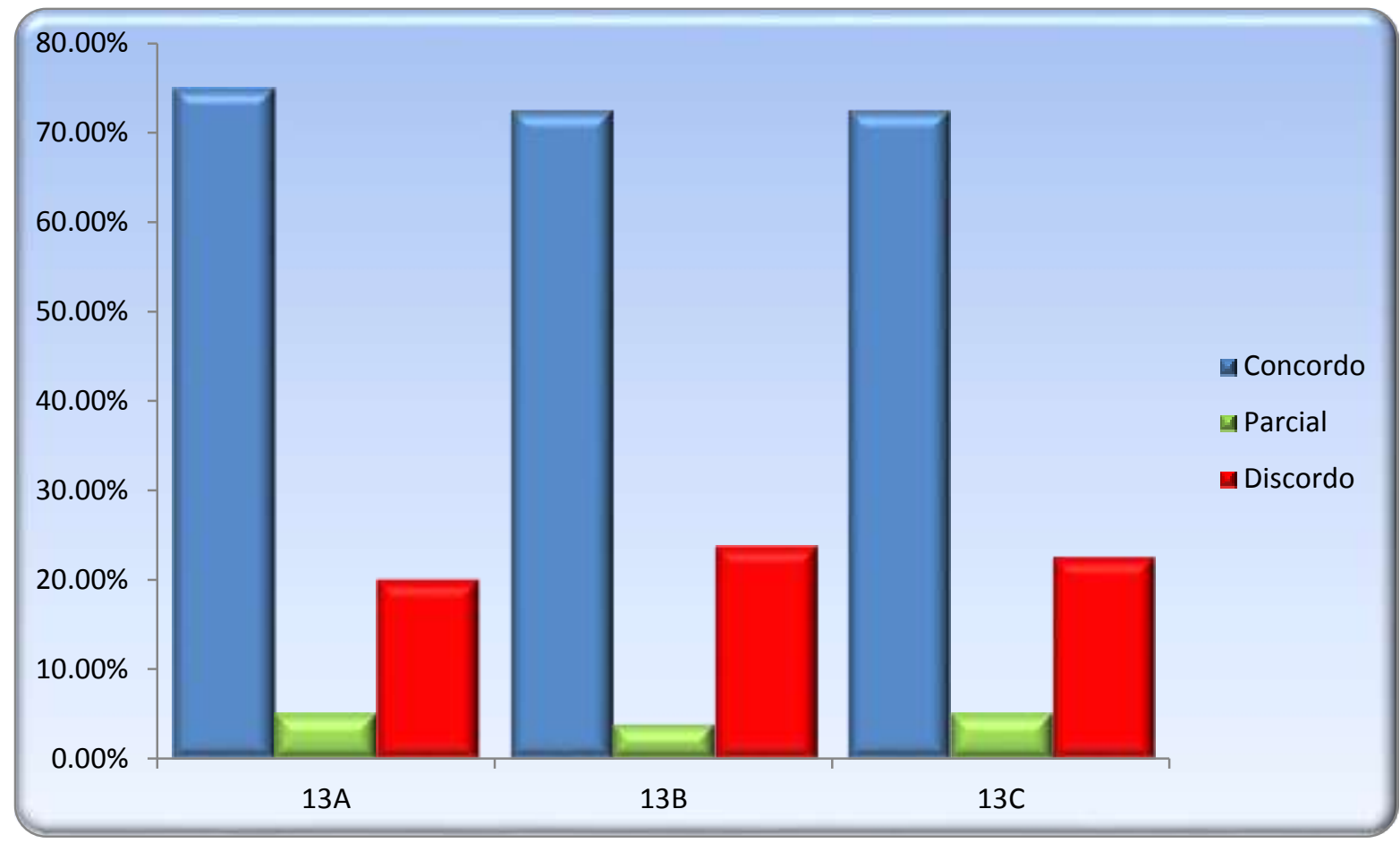

D - Mensuração de Ativos e Passivos financeiros

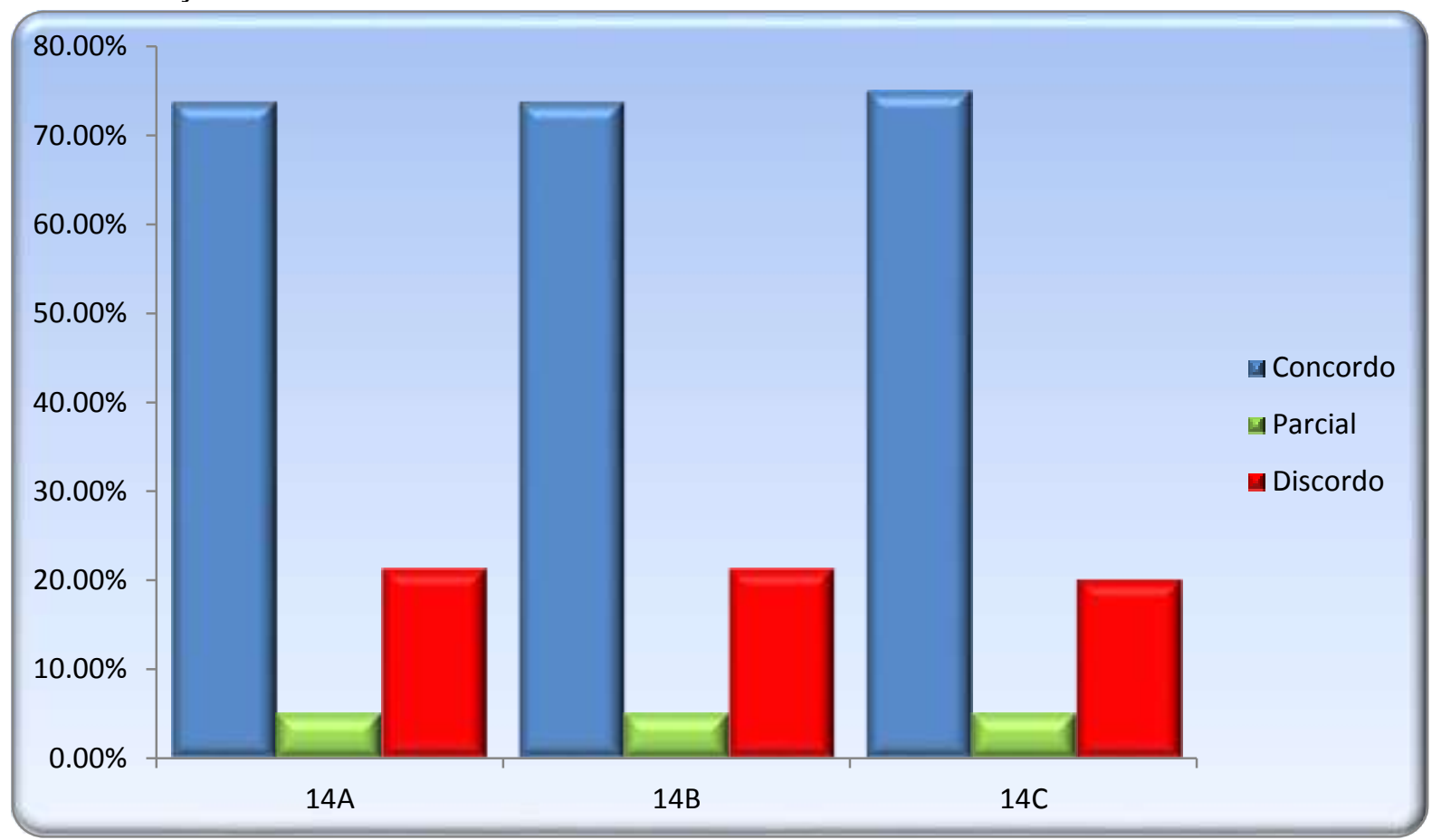

Fonte: Dados da Pesquisa

Segundo o IASB (2014a), muitos usuários comentaram concordar que uma única base de mensuração para todos os ativos e passivos não pode fornecer as informações mais relevantes para os usuários das demonstrações financeiras e diferentes bases de mensuração 
são úteis, dependendo das circunstâncias. No entanto, alguns usuários também comentaram que uma abordagem de mensuração mista diminui a utilidade e a comparabilidade das mensurações agregadas, como o total das demonstrações financeiras, o lucro ou perda, o retorno sobre o patrimônio líquido e retorno sobre o investimento. Usando diferentes bases de mensuração é possível reduzir a compreensibilidade, especialmente se a base de mensuração é complexa. Outro grupo tinha uma visão diferente: que a Estrutura Conceitual deve indicar que o valor justo é a medida mais relevante. Na opinião desses, as mensurações a valor justo refletem as estimativas mais atuais e completas sobre o valor do bem ou obrigação, inclusive os montantes, prazos e risco dos fluxos de caixa futuros atribuíveis ao Ativo ou Passivo. Tais expectativas estão no cerne de todas as trocas de ativos. Alguns também se referem às propostas do documento de discussão sobre o uso de Other Comprehensive Income (OCI) Outros Resultados Abrangentes -, afirmando que o uso de diferentes bases de mensuração na demonstração da posição financeira e as demonstrações de desempenho financeiro também pode ser útil.

Adicionalmente, ressalta o IASB (2014a) que os usuários tinham opiniões divergentes sobre a base da seleção de mensuração. Por um lado, o conceito de que a seleção de uma medida dependerá de como um ativo contribui para o fluxo de caixa ou como um passivo será cumprido é atraente para itens específicos. Em particular, alguns sugeriram que esta abordagem refletiria melhor modelo de negócio de uma entidade. Por outro lado, isso irá reduzir a comparabilidade e consistência da contabilidade, principalmente se a intenção de gerenciamento é usada para decidir sobre a medida. Alguns manifestaram preocupação com a utilidade da informação, se a gestão é permitida escolher a base de mensuração, dependendo do que eles decidem ser o seu modelo de negócio. Em vez disso, os respondentes pensam que o IASB deve determinar a base de mensuração mais relevante para um determinado ativo com base em suas características. Eles querem a base de mensuração que melhor capta o fenômeno econômico mais relevante.

A Tabela 10 mostra o índice de concordância das perguntas dessa seção, onde o menor indicador alcançado foi a pergunta 12D com 1,67 (para cada respondente que discordou ou concordou parcialmente, 1,67, concordou) e o maior indicador foi 10,43 (para cada respondente que discordou ou concordou parcialmente, 10,43, concordaram) na pergunta $11 \mathrm{~F}$. 
Tabela 10 - Índice de Concordância/Discordância - Mensuração

\begin{tabular}{|c|c|c|c|c|c|c|c|c|c|}
\hline & $11 \mathrm{~A}$ & $11 B$ & $11 \mathrm{C}$ & 11D & $11 E$ & $11 F$ & $12 \mathrm{~A}$ & 12B & \\
\hline Concordo & 65 & 69 & 68 & 58 & 67 & 73 & 56 & 52 & \\
\hline Discordo & 12 & 6 & 7 & 12 & 10 & 3 & 17 & 21 & \\
\hline Parcial & 3 & 5 & 5 & 10 & 3 & 4 & 7 & 7 & \\
\hline Índice & 4,33 & 6,27 & 5,67 & 2,64 & 5,15 & 10,43 & 2,33 & 1,86 & \\
\hline & $12 \mathrm{C}$ & 12D & 13A & 13B & $13 \mathrm{C}$ & $14 A$ & $14 B$ & $14 \mathrm{C}$ & Total \\
\hline Concordo & 55 & 50 & 60 & 58 & 58 & 59 & 59 & 60 & 967 \\
\hline Discordo & 18 & 24 & 16 & 19 & 18 & 17 & 17 & 16 & 233 \\
\hline Parcial & 7 & 6 & 4 & 3 & 4 & 4 & 4 & 4 & 80 \\
\hline Índice & 2,20 & 1,67 & 3,00 & 2,64 & 2,64 & 2,81 & 2,81 & 3,00 & 3,09 \\
\hline
\end{tabular}

Fonte: Dados da Pesquisa

No tocante à participação dos setores, os preparadores foram os que mais concordaram, 84,21\%, seguido pela academia, 79,46\%. Já os auditores foram aqueles que mais discordaram, 45,31\% seguidos pelos reguladores, 22,92\%. Novamente, o IASB flexibiliza, permitindo várias formas de mensurações diferentes, desde que o resultado dessas mensurações incorra em informações relevantes e que representem com fidedignidade o fenômeno que se propõe a representar, visando maior qualidade da informação reportada nos relatórios financeiros, convergindo com as necessidades dos preparadores. No tocante à academia, via de regra, conforme elucidado na própria evolução da Estrutura Conceitual, há preferencia por normas mais flexíveis (mesmo nos EUA, em que no transcorrer dos anos, a partir da década de 1930, houve forte pressão da SEC em relação à rigidez na emissão de normas contábeis que fossem claramente definidas). Por outro lado, a elevada discordância dos auditores pode ser elucidada pela elevação das dificuldades no tocante à emissão de opiniões sobre as demonstrações financeiras.

\subsubsection{Apresentação e Divulgação}

As perguntas alusivas à Apresentação e Divulgação são: $16 \mathrm{~A}^{39}, 16 \mathrm{~B}, 17^{40}$ e $18^{41}$, sendo que, 16A e 16B explanam o escopo e conteúdo das apresentações, 17, orientações

\footnotetext{
${ }^{39}$ Dentro desse contexto, você concorda com as visões preliminares sobre o escopo e o conteúdo da orientação que deveria ser incluída na Estrutura Conceitual sobre:

a) apresentação nas demonstrações financeiras primárias, incluindo:

i) o que são as demonstrações financeiras primárias;

ii) o objetivo das demonstrações financeiras primárias

iii) classificação e agregação;

iv) compensação; e
} 
adicionais ou material educacional acerca da materialidade por fora da Estrutura Conceitual e 18, princípios da comunicação.

A Figura 10 exibe o ponto de vista dos respondentes e certa similaridade é evidenciada na análise. A maioria dos respondentes concorda com a proposta, sendo 65\%, 63,75\%, 72,5\% e $83,75 \%$ o percentual de concordância, respectivamente às questões da seção. O desvio padrão entre as respostas concordantes é 7,35 e o desvio médio é 5,5. Principalmente em relação às perguntas sobre apresentação nas demonstrações financeiras primárias - $16 \mathrm{~A}-\mathrm{e}$ divulgação nas notas as demonstrações financeiras - 16B - percebe-se enorme similaridade, onde a maioria dos que concordavam com a primeira, também concordavam com a segunda e vice-versa.

Os pressupostos previamente citados nessa seção são confirmados quando se analisa o índice de concordância em conformidade com a Tabela 11. Não ocorreu valores menores que 1 , visto que isso representaria opiniões negativas ou parciais superiores às positivas. Desta forma, as opiniões concordantes são substancialmente superiores às opiniões discordantes e parciais. A pergunta 18, alcançou maior indicador nesta seção, 5,15 (para cada resposta em que o respondente discordou ou concordou parcialmente, 5,15 concordou). Já a pergunta 16B, obteve o menor indicador, 1,76 (para cada resposta na qual o respondente discordava ou concordava parcialmente, 1,76 discordava).

v) a relação entre as demonstrações financeiras primárias.

b) divulgações nas notas às demonstrações financeiras, incluindo:

i) o objetivo das notas às demonstrações financeiras; e

ii) o escopo das notas às demonstrações financeiras, incluindo os tipos de informação e divulgações que são relevantes para atender o objetivo das notas às demonstrações financeiras, informação prospectiva e informação comparativa.

O IASB pergunta: Você concorda com essa visão? Por que ou por que não?

${ }^{40}$ A visão preliminar do IASB é que o conceito de materialidade é descrito claramente na Estrutura Conceitual existente. Consequentemente, o IASB não propõe modificar, ou adicionar, as orientações sobre materialidade na Estrutura Conceitual. Contudo, o IASB está considerando desenvolver orientações adicionais ou material educacional acerca da materialidade por fora do projeto da Estrutura Conceitual. Você concorda com essa abordagem? Por que ou por que não?

${ }^{41}$ A visão preliminar do IASB é que ele deve considerar os princípios da comunicação ao desenvolver ou modificar as orientações de divulgação nas IFRSs. Você concorda que os princípios de comunicação devem ser parte da Estrutura Conceitual? Por que ou por que não? 
Figura 10 - Nível de Concordância/Discordância das Perguntas sobre Apresentação e Divulgação

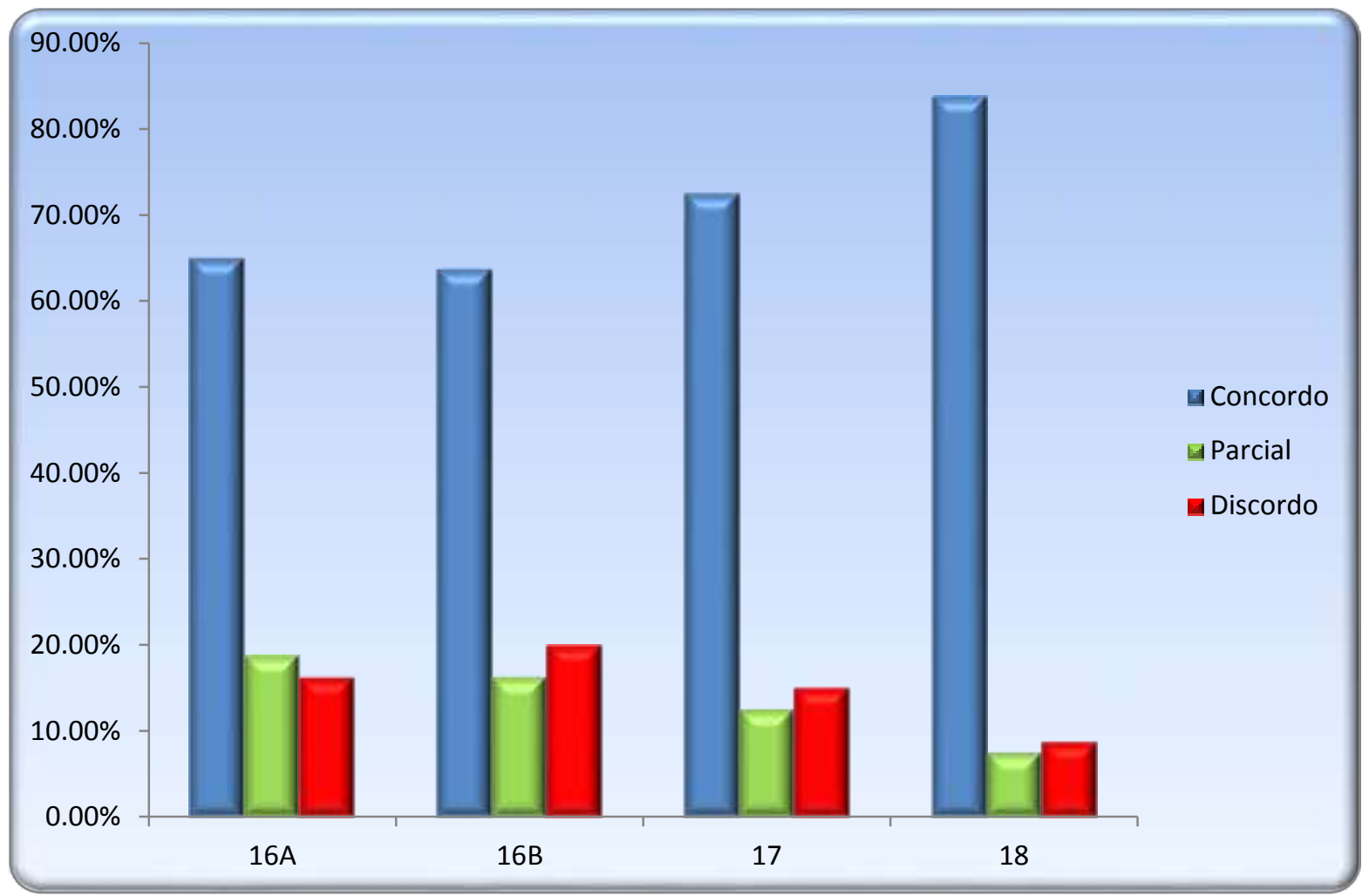

Fonte: Dados da Pesquisa

Tabela 11 - Índice de Concordância/Discordância - Apresentação e Divulgação

\begin{tabular}{lccccc}
\hline & $\mathbf{1 6 A}$ & $\mathbf{1 6 B}$ & $\mathbf{1 7}$ & $\mathbf{1 8}$ & Total \\
\hline \hline Concordo & 52 & 51 & 58 & 67 & 228 \\
\hline Discordo & 13 & 16 & 12 & 7 & 48 \\
\hline Parcial & 15 & 13 & 10 & 6 & 44 \\
\hline Índice & $\mathbf{1 , 8 6}$ & $\mathbf{1 , 7 6}$ & $\mathbf{2 , 6 4}$ & $\mathbf{5 , 1 5}$ & $\mathbf{2 , 4 8}$ \\
\hline
\end{tabular}

Fonte: Dados da Pesquisa

De acordo com o IASB (2014a), alguns respondentes pediram mais foco na apresentação e divulgação. Outros não acham que o problema seja a sobrecarga de divulgação, mas sim a transparência e qualidade. Além disso havia comentários ressaltando que as divulgações são frequentemente debatidas como uma reflexão tardia e gostariam que o IASB repensasse o processo de criação de divulgações, para promover a coerência em requisitos de divulgação.

Alguns afirmaram que o material sugerido pelo documento de discussão para inclusão no Quadro Conceitual não era suficientemente abrangente e que era difícil ver qual o impacto 
que o material terá ou causará ao nível dos padrões. Quanto à materialidade, houve um apoio geral para mais orientação ou material educativo sobre a materialidade. No entanto, outros sugeriram que o material educativo possa não ser suficiente. Alguns sugeriram que a Estrutura Conceitual não deve se obstar a limiares quantitativos. Outros sugeriram que uma avaliação qualitativa da materialidade é igualmente importante.

Quanto aos setores de atuação, o maior nível de concordância foi atingido pelos reguladores, perfazendo 83,33 pontos percentuais. Na segunda posição, despontam os preparadores, com 81,58. Já os maiores discordantes foram associação profissional e academia com 23,75 e 17,86 pontos percentuais, respectivamente. Os reguladores estão preocupados com a proteção dos investidores e procuram garantir que as informações fornecidas sejam de alta qualidade e representem com fidedignidade o que se propõe a representar. De acordo com Murcia (2009), a assimetria informacional entre os controladores e usuários externos da companhia cria a demanda para o disclosure corporativo, que é o canal de transmissão das informações da empresa para o mercado. Nesse cenário, o disclosure tem uma função facilitadora: é realizado de forma a auxiliar o processo decisório dos usuários. Para Shin (2003), nos momentos de crise e turbulência nos mercados internacionais, o disclosure é utilizado pelos órgãos reguladores, no sentido de elevar a qualidade da informação contábil. Segundo Levitt (1988, apud MURCIA, 2009), o sucesso de um mercado de capitais é diretamente dependente da qualidade das normas contábeis e do disclosure, pois esses fornecem confiança aos investidores de que as demonstrações contábeis são confiáveis. Esses fatos fundamentam o maior nível de concordância dos reguladores nesta seção.

\subsubsection{Apresentação na DRA - Lucros e Perdas e Outros Resultados Abrangentes}

No que tange à apresentação na Demonstração do Resultado Abrangente, Lucros e Perdas e Outros Resultados Abrangentes, a maioria dos respondentes concordam com as três questões analisadas $\left(19^{42}, 20^{43}\right.$ e $\left.21^{44}\right)$. A pergunta 19 , sobre a proposta de exigência do total

\footnotetext{
${ }^{42}$ A visão preliminar do IASB de que a Estrutura Conceitual deveria exigir um total ou subtotal para lucros ou perdas. Você concorda? Por que ou por que não? Se você não concorda, você acha que o IASB deveria ainda ser capaz de exigir um total ou subtotal de lucros ou perdas ao desenvolver ou revistar Normas específicas?

${ }^{43}$ A visão preliminar do IASB é que a Estrutura Conceitual deveria permitir ou exigir pelo menos alguns dos itens de receita e despesa previamente reconhecidos em OCI a serem reconhecidos subsequentemente em lucros ou perdas, isto é, reciclados. Você concorda? Por que ou por que não? Se você concorda, você acha que todos os itens de receita e despesa apresentados em OCI deveriam ser reciclados em lucros ou perdas? Por que ou por que não? Se você não concorda, como iria abordar os fluxos de caixa da contabilidade de hedge (hedge accounting)?

${ }^{44}$ Duas abordagens são exploradas que descrevem quais itens poderiam se incluídos em OCI: uma abordagem minuciosa e uma abordagem ampla. Qual dessas abordagens você apoia, e por quê? Se você apoia uma
} 
ou subtotal para lucros e perdas, atingiu o maior nível de concordância da seção, 82,5\%, conforme a Figura 11, seguida pela pergunta 21 - abordagens sugeridas para Outros Resultados Abrangentes - com, 67,5\% e pergunta 20 - reciclagem $^{45}$ de despesas e receitas previamente reconhecidas em outros resultados abrangentes, com 58,75\%.

Figura 11 - Nível de Concordância/Discordância das Perguntas sobre Apresentação na DRA - Lucros e Perdas e Outros Resultados Abrangentes

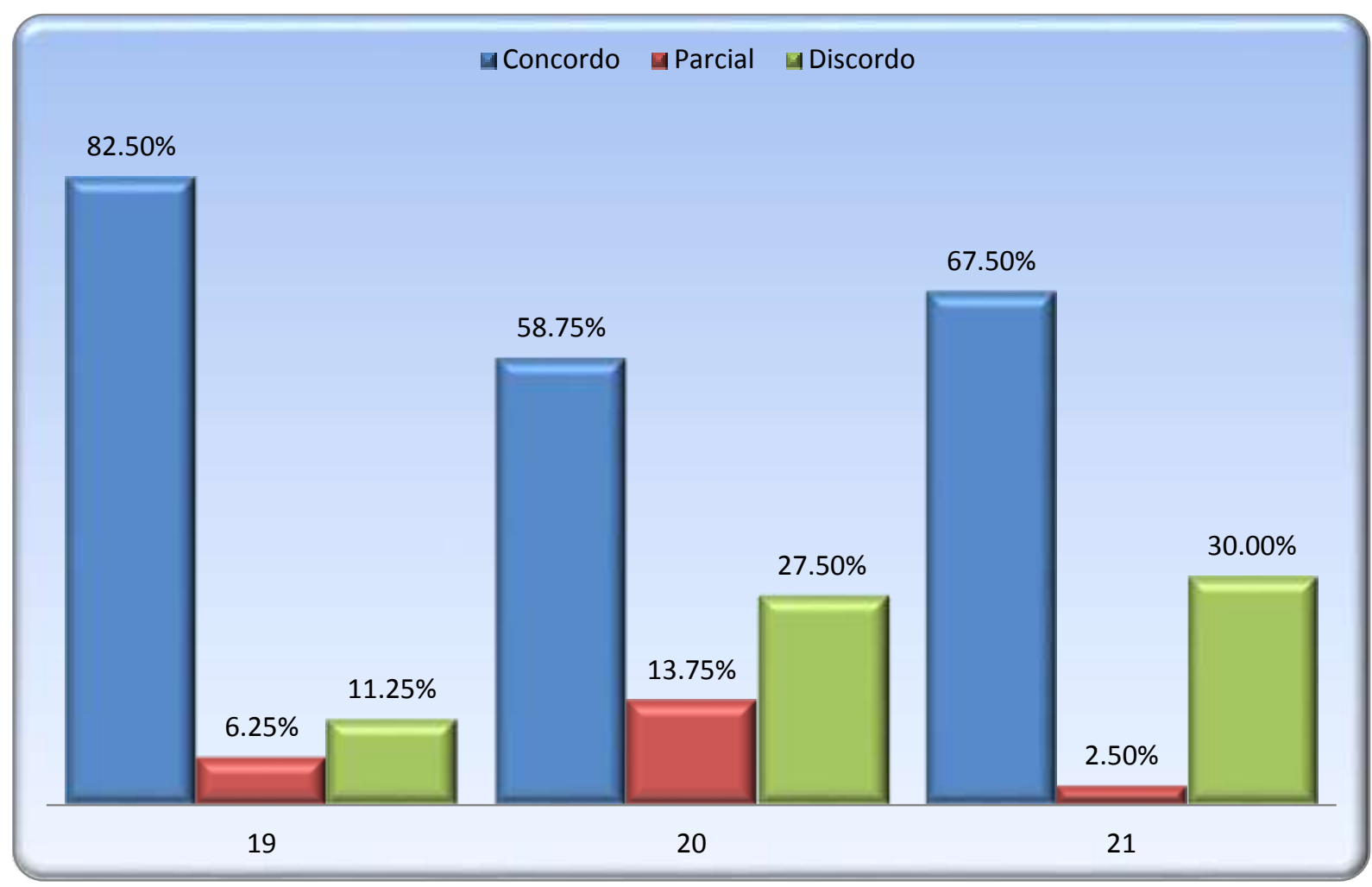

Fonte: Dados da Pesquisa

A pergunta 21, em especial, além de solicitar a opinião dos respondentes quanto à concordância ou discordância, propõe três abordagens para o tratamento de Outros Resultados Abrangentes: Abordagem 1 - proíbe a reciclagem; Abordagem 2A - uma abordagem estreita de descrever quais itens podem ser reconhecidos em Outros Resultados Abrangentes e Abordagem 2B - uma abordagem mais ampla de descrever quais itens podem ser reconhecidos em Outros Resultados Abrangentes ${ }^{46}$.

abordagem diferente, por favor, descreva essa abordagem e explique por que você acredita que é preferível às abordagens descritas neste Documento de Discussão.

45 Alguns itens, a maioria ganhos e perdas não realizados - resultados de recálculos - são incluídos em OCI. Alguns ganhos e perdas reconhecidos em OCI são reclassificados para lucros ou perdas quando realizados ou em um momento especificado por Normas específicas. Tal reclassificação é chamada de Reciclagem (DP/2013/1).

${ }^{46}$ Abordagens 1, 2A e 2B são explanadas na Fundamentação Teórica. 
Em princípio, o IASB favorece as abordagens $2 \mathrm{~A}$ e $2 \mathrm{~B}$, para as quais foi solicitado qual seria a preferência dos respondentes. A Figura 12 evidencia a preferência dos usuários pela abordagem 2B, a qual permitiria que mais itens fossem reconhecidos em Outro Resultados Abrangentes do que a Abordagem 2A, na maioria dos casos, em 51\%. Alguns respondentes sugeriram uma abordagem intermediária entre $2 \mathrm{~A}$ e $2 \mathrm{~B}$, a qual foi classificada em outras.

\section{Figura 12 - Preferencia dos Respondentes em relação às abordagens OCI}

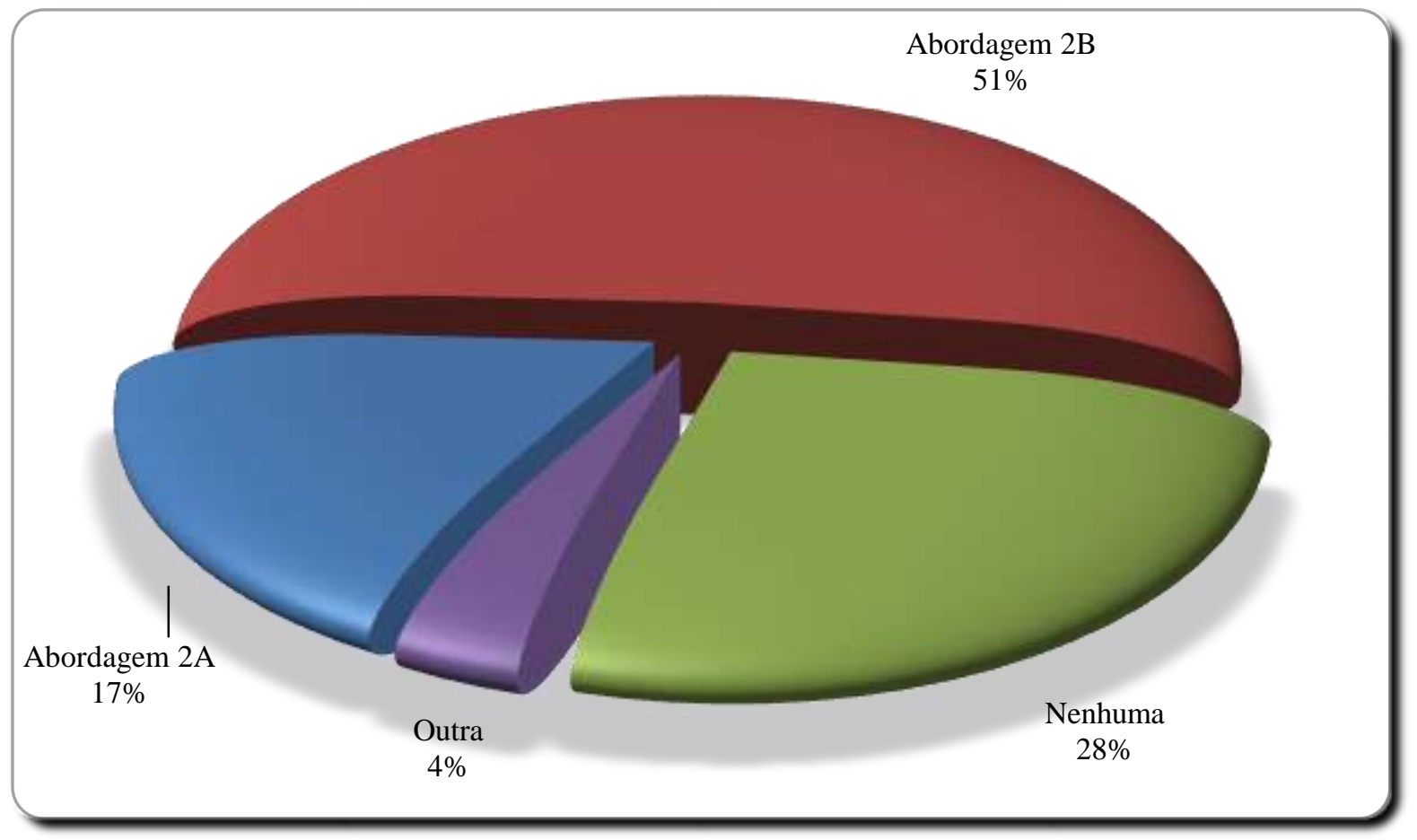

Fonte: Dados da Pesquisa

Na Tabela 12 é destacado, adicionalmente, o índice de concordância, o qual ratifica os pressupostos acima citados. Para todas as questões, o índice calculado foi superior a 1, o que significa que as respostas positivas são superiores às respostas negativas ou parciais. A pergunta 19, atingiu o maior índice de concordância, em que para cada respondente que discordou ou concordou parcialmente, 4,71 concordaram. Já a pergunta 20 atingiu o menor índice de concordância da seção, sendo que para cada respondente que discordou ou concordou parcialmente, 1,42 concordou.

Suplementarmente foram analisadas as perspectivas dos respondentes em relação ao setor de atuação. Foi constatado que o maior nível de aceitação ocorreu por parte dos preparadores, seguidos pela academia, respectivamente com 80,70 e 76,17 pontos percentuais. 
Os que mais discordaram foram os auditores e reguladores atingindo, respectivamente 37,50 e 22,22 pontos percentuais.

Tabela 12 - Índice de Concordância/Discordância - Apresentação na DRA - Lucros e Perdas e ORA

\begin{tabular}{lcccc}
\hline & $\mathbf{1 9}$ & $\mathbf{2 0}$ & $\mathbf{2 1}$ & Total \\
\hline \hline Concordo & 66 & 47 & 54 & 167 \\
\hline Discordo & 9 & 22 & 24 & 55 \\
\hline Parcial & 5 & 11 & 2 & 18 \\
\hline Índice & $\mathbf{4 , 7 1}$ & $\mathbf{1 , 4 2}$ & $\mathbf{2 , 0 8}$ & $\mathbf{2 , 2 9}$
\end{tabular}

Fonte: Dados da Pesquisa

Segundo o IASB (2014a), alguns usuários pensam que todos os itens incluídos em Outros Resultados Abrangentes devem ser reciclados, ou por causa da importância do resultado, ou porque a reciclagem é necessária, para atingir a sua abordagem preferida, a fim de distinguir lucro ou perda de Outros Resultados Abrangentes. Esses usuários sugeriram que, ser incapaz de determinar o gatilho apropriado para a reciclagem, não é uma boa razão para a não reciclagem de todos os elementos. Alguns sugeriram que a reciclagem aumenta o risco de gerenciamento de resultados e diminui a compreensibilidade e comparabilidade. Portanto, eles preferem proibir ou limitar a reciclagem. Por outro lado, outros sugeriram que o uso de Outros Resultados Abrangentes, sem reciclagem, daria à gestão um incentivo para subestimar resultados (por exemplo, por subestimar o custo do serviço de pensões). Independentemente de seus pontos de vista, muitos usuários sugeriram que o tratamento de itens, como reciclados ou não, devem ser claramente divulgados para melhorar a compreensão dos usuários de reciclagem e para ajudá-los a fazer os ajustes. Alguns outros concordam quanto à reciclagem de alguns itens e outros não, desde que haja divulgação clara do tratamento.

\subsubsection{Outras Questões}

Na seção 9, foram inseridas outras questões, tais como: Pergunta 22 - o IASB não planeja reconsiderar fundamentalmente o conteúdo da Estrutura Conceitual existente ${ }^{47}$;

\footnotetext{
${ }^{47}$ O IASB aborda os capítulos da Estrutura Conceitual existente que foram publicados em 2010 e como esses capítulos tratam os conceitos de gestão, confiabilidade e prudência. O IASB fará mudanças a esses capítulos se o trabalho no resto da Estrutura Conceitual destacar áreas que precisam de esclarecimento e mudanças. Contudo, o IASB não planeja reconsiderar fundamentalmente o conteúdo desses capítulos. Você concorda com essa abordagem? Se você acredita que o IASB poderia considerar mudanças a esses capítulos (incluindo como esses capítulos tratam os conceitos de gestão, confiabilidade e prudência), explique essas mudanças e os motivos para elas, e, explique o mais precisamente possível como elas iriam afetar o restante da Estrutura Conceitual.
} 
Pergunta 23 - ao desenvolver ou revisar Normas específicas, o IASB deve considerar como uma entidade conduz suas atividades de negócios ${ }^{48}$; Pergunta 24 - unidade de conta será decidida normalmente enquanto o IASB desenvolver ou revisar normas específicas ${ }^{49}$; e Pergunta 26 - o IASB planeja incluir as descrições existentes e a discussão sobre conceitos de capital na Estrutura Conceitual, revisada praticamente inalterada ${ }^{50}$.

A figura 13 revela a analogia ocorrida entre a maioria das questões, exceto para a questão 22 a qual apresentou dissimilitude das demais. Esse fato é justificado devido à diversidade entre os assuntos da seção. Apenas 42,5\% dos respondentes concordam que os capítulos existentes da Estrutura Conceitual não devem ser modificados em algum aspecto. Já as demais questões obtiveram percentuais de aceitação semelhantes, sendo 68,75\%, 68,75\% e $70,00 \%$, para as questões 23,24 e 26 , respectivamente.

Através da Tabela 13 podem-se destacar os indicadores calculados. Para a pergunta 22 o índice de concordância foi menor que 1, o que significa que as opiniões discordantes e opiniões parciais foram superiores às opiniões concordantes. No tocante às demais questões, o índice calculado demonstra que as opiniões concordantes foram superiores às opiniões discordantes e parciais. O maior índice de concordância foi obtido na questão 24, em que para cada respondente que discordou ou concordou parcialmente, três concordaram.

No que diz respeito aos setores de atuação, os maiores concordantes desta seção foram os preparadores, atingindo $71,05 \%$, seguidos pelos auditores com $68,75 \%$. No tocante aos maiores discordantes, figuram a academia e os normatizadores, atingindo, respectivamente, $35,71 \%$ e $30,68 \%$. Notadamente, segue padrão da maioria das seções em que os preparadores foram os mais concordaram. Em linhas gerais, esse fato é fundamentado pela possível preferencia deles por flexibilização das políticas e práticas contábeis no que tange ao reconhecimento, mensuração e evidenciação dos elementos dos relatórios financeiros.

\footnotetext{
${ }^{48}$ Este Documento de Discussão não define o conceito de modelo de negócios. Contudo, a visão preliminar do IASB é de que demonstrações financeiras podem se tornar mais relevantes se o IASB considerar, ao desenvolver ou revisar Normas específicas, como uma entidade conduz suas atividades de negócios. Você acha que o IASB deveria usar o conceito de modelo de negócios ao desenvolver e revisar Normas específicas? Por que ou por que não? Se você concorda, em quais áreas você acha que o conceito de modelo de negócios seria útil? O IASB deveria definir o modelo de negócios? Por que ou por que não? Se você acha que modelo de negócios deva ser definido, como você o definiria?

${ }^{49}$ A visão preliminar do IASB é que a unidade de conta será decidida normalmente enquanto o IASB desenvolve o revisa normas específicas e que, ao escolher a unidade de conta, o IASB deveria considerar as características qualitativas das informações financeiras úteis. Você concorda? Por que ou por que não?

${ }^{50}$ O IASB planeja incluir as descrições existentes e a discussão sobre conceitos de manutenção de capital na Estrutura Conceitual revisada praticamente inalterada até que o momento em que uma Norma nova ou revisada sobre contabilidade em alta inflação indique uma necessidade de mudança. Você concorda? Por que ou por que não?
} 
Figura 13 - Nível de Concordância/Discordância das Perguntas sobre Outras Questões

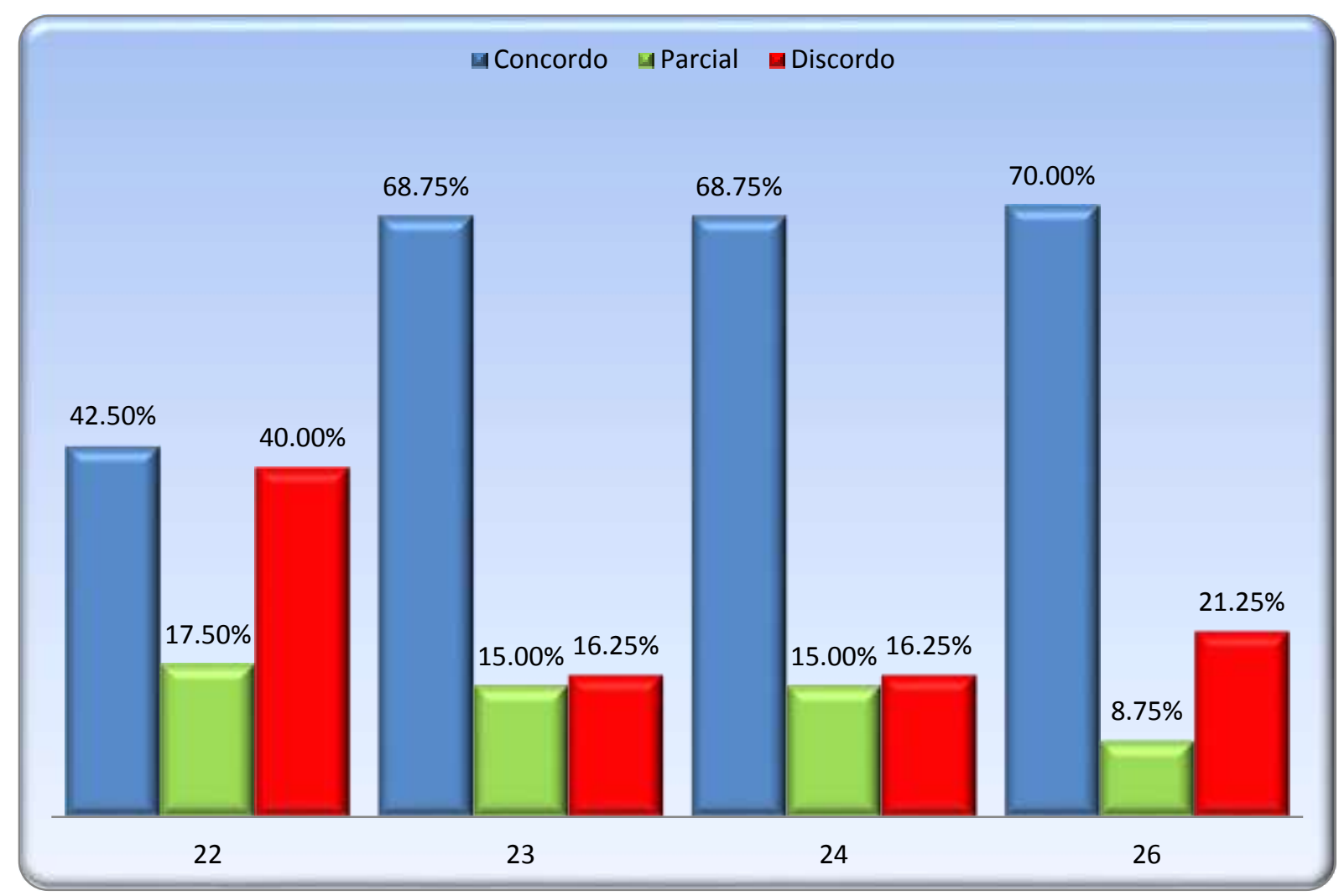

Fonte: Dados da Pesquisa

Tabela 13 - Índice de Concordância/Discordância - Outras Questões

\begin{tabular}{lccccc}
\hline & $\mathbf{2 2}$ & $\mathbf{2 3}$ & $\mathbf{2 4}$ & $\mathbf{2 6}$ & Total \\
\hline \hline Concordo & 34 & 55 & 60 & 56 & 205 \\
\hline Discordo & 32 & 13 & 16 & 17 & 78 \\
\hline Parcial & 14 & 12 & 4 & 7 & 37 \\
\hline Índice & $\mathbf{0 , 7 4}$ & $\mathbf{2 , 2 0}$ & $\mathbf{3 , 0 0}$ & $\mathbf{2 , 3 3}$ & $\mathbf{1 , 7 8}$
\end{tabular}

Fonte: Dados da Pesquisa

Segundo o IASB (2014 a), muitos usuários expressaram a opinião de que o IASB deve reconsiderar pelo menos alguns aspectos dos capítulos 1 e 3 da Estrutura Conceitual existente, enquanto outros indicaram que esses capítulos são fundamentalmente sólidos. Durante as reuniões com os usuários, diversas definições dos conceitos surgiram, o que levou alguns a sugerir que deveriam ser repensadas algumas das questões que, pelo menos, ajudaria a reduzir mal entendidos e confusões. Algumas preocupações expressas de que os capítulos 1 e 3 revisados podem resultar em divergência com os EUA GAAP, uma vez que foram desenvolvidos conjuntamente pelo IASB e FASB. 
Alguns usuários também sugeriram que deve ser dado mais destaque a "true and fair view". Outros, ainda, baseados no Reino Unido, sugerem que para fornecer uma visão justa e verdadeira no Reino Unido, gestão, prudência e confiabilidade precisam ser reintegradas como características qualitativas fundamentais da Estrutura Conceitual. No entanto, um grupo de usuários era de parecer contrário, em particular, que o uso da prudência não resultaria em uma imagem verdadeira e apropriada.

Usuários que se identificaram como investidores de longo prazo pediram ênfase no uso do modelo de negócio no desenvolvimento de Normas. Eles comentaram que a definição de modelo de negócio vai ser difícil. No entanto, alguns sugeriram que poderia ser definido, geralmente com um foco específico sobre os meios pelos quais a empresa pretende gerar retornos acima do custo de capital próprio, em uma base sustentável de longo prazo. Porém, outros usuários discordaram, enfatizando o modelo de negócio. Eles sugeriram que referencia ao modelo de negócio é um caminho para a introdução de tendenciosidade da administração e defendeu uma base mais objetiva de obter uma representação fiel de ativos e passivos. Em se tratando das questões acerca da unidade de conta e manutenção de capital, muitos apoiaram a direção geral no documento de reflexão.

\subsubsection{Visão Geral}

À medida que se buscou identificar as questões de maior aceitação e as de maior rejeição pelos respondentes, foi analisado o nível de concordância ou de discordância em relação às questões sobre as seções propostas no DP/2013/1: 1) introdução; 2) elementos das demonstrações financeiras; 3) orientações adicionais de apoio às definições de ativo e passivos; 4) reconhecimento e desreconhecimento; 5) definição de capital próprio e distinção entre passivos e instrumento de patrimônio; 6) mensuração; 7) apresentação e divulgação; 8) apresentação na demonstração de resultados abrangentes; e 9) outras questões.

Com base na análise geral, foi possível identificar que 69,72\% das respostas fornecidas pelos respondentes são do tipo "concordo" com a proposta do IASB. Dessa forma foi possível testar as hipóteses previamente estabelecidas da pesquisa que eram:

$\mathrm{H}_{0}: \mu<0,5$ - A média de concordância dos respondentes das perguntas do DP/2013/1 é menor que $50 \%$, isto é, a maioria dos respondentes discorda da proposta do IASB, no tocante a proposta de mudança da Estrutura Conceitual. 
$\mathrm{H}_{1}: \mu \geq 0,5$ - A média de concordância dos respondentes das perguntas do DP/2013/1 é maior ou igual a $50 \%$, isto é, a maioria dos respondentes concorda com a proposta do IASB, no tocante a proposta de mudança da Estrutura Conceitual.

Com base na análise geral foi possível rejeitar a $\mathrm{H}_{0}$ em favor de $\mathrm{H}_{1}$, em que a maioria dos agentes estão de acordo com pressupostos previamente estabelecidos no DP/2013/1 no tocante as alterações da Conceptual Framework for Financial Reporting emitida pelo Internantional Accounting Standard Board.

No que diz respeito à análise individualizada, seção por seção, os resultados foram convergentes com a análise geral, isto é, em todas as seções analisadas foi identificado que a maioria das respostas fornecidas pelos usuários era do tipo "concordo com a proposta do IASB”. A seção com maior índice de aceitação foi a seção 3 - Orientação Adicional de Apoio as Definições de Ativo e Passivo, que atingiu 84,38\% de concordância. A seção com menor índice de aceitação foi à seção 5 - Definição de PL e Distinção de Passivo e Instrumento de Capital. Para essa seção o índice de discordância foi 36,88\%.

Em relação à análise individualizada, pergunta a pergunta, foi identificado índice de concordância maior que 50\% na maioria delas, exceto para as perguntas 10C e 10D, que atingiram 53,75\% e 55\% de discordância, respectivamente. Somente nessas duas perguntas, foi possível evidenciar índice de discordância superior ao índice de concordância.

As perguntas com maior índice de aceitação foram: 11F, seção 6 - Mensuração: os benefícios de uma base de mensuração específica para os usuários das demonstrações financeiras precisam ser suficientes para justificar o seu custo, atingindo $91,25 \%$ de concordância; 5, seção 3 - Orientação Adicional de Apoio as Definições de Ativo e Passivo: A discussão considera que a possibilidade de se estreitar a definição de um passivo para incluir apenas obrigações que são asseguráveis por lei ou outro meio equivalente. Porém, o IASB, provisoriamente, favorece a retenção das definições existentes, que englobam ambas as obrigações legais e construtivas - e a adição de mais orientações para ajudar a distinção da obrigação construtiva da compulsão econômica, atingindo 87,5\% de concordância; e, 11C, seção 6 - Mensuração: Ao selecionar a mensuração a utilizar para um item específico, o IASB deve considerar qual informação essa mensuração irá produzir tanto na demonstração de posição financeira quanto na(s) demonstração(ões) de lucros ou perdas e OCI, atingindo 85\% de concordância.

Adicionalmente os respondentes justificaram suas respostas por meio de seus argumentos teóricos e não teóricos classificados e agrupados em 6 categorias taxonômicas detalhadas na seção seguinte. 


\subsection{TAXONOMIA DOS ARGUMENTOS}

Adicionalmente à classificação por nível de concordância/discordância das perguntas analisadas, fez-se necessário a categorização por tipo de argumento, com o propósito de compreender de que forma os respondentes embasaram suas respostas - concordantes, discordantes e parciais - acerca do DP/2013/1.

As categorias definidas para classificação - adaptadas de Yen, Hirst e Hopkins (2007) - são: escopo, definição, due process, efeitos externos e internos, exemplos e sem argumento. $\mathrm{Na}$ categoria definição forma classificados os argumentos em que os respondentes concordavam, discordavam e concordavam parcialmente com o modelo contábil, se utilizam de bases teóricas ou definições, tais como expostas na Estrutura Conceitual ou definição exibida em outra norma. No tocante a categoria escopo, figuraram os argumentos em que os respondentes expuseram seu ponto de vista com base em experiência prática, ou no que acham, sem quaisquer utilizações de definições ou bases teóricas. Em se tratando da categoria due process, foram expostos os argumentos para os quais os respondentes embasavam suas respostas citando outras normas ou a Estrutura Conceitual, confrontando ou não com a proposta do DP/2013/1. No que diz respeito a categoria efeitos externos e internos, foram classificados os argumentos em que os respondentes citavam implicações para os usuários externos e internos. A categoria exemplo foi utilizada para argumentos em que os usuários citavam exemplos teóricos ou práticos. Já as respostas em que os respondentes apresentavam opinião quanto a concordância, discordância ou concordância parcial sem justificar, argumentar ou embasar a resposta, foram classificados na categoria sem argumentos.

A Figura 14 expressa a taxonomia dos argumentos utilizados pelos respondentes, para todas as perguntas analisadas na pesquisa, no tocante ao DP/2013/1. O tipo de argumento mais utilizado - de acordo com a classificação da pesquisa - foi o da categoria escopo, utilizado em $49 \%$ do total de perguntas. Esse comportamento evidencia que grande parte dos respondentes fazem uso da experiência prática e o que pensam acerca de determinados assuntos, procurando inferir suas possíveis consequências, evidenciando sua robustez e debilidades, sem a utilização de qualquer embasamento teórico que desse suporte a temática analisada.

Em todas as seções analisadas, pode-se verificar esse comportamento por parte dos respondentes; fato esse convergente com alguns autores, porém divergente em alguns aspectos. A pesquisa realizada por Matos (2013) compartilha esse mesmo comportamento no que tange ao reconhecimento e mensuração. Por outro lado, exibe conduta divergente no 
tocante às perguntas sobre apresentação, para as quais os principais argumentos foram os da categoria efeitos externos. No geral, $49 \%$ dos argumentos pertencem à categoria escopo, seguido pelas respostas sem argumento, isto é, figuraram as circunstâncias em que os respondentes não utilizavam nenhum argumento para justificar suas respostas, não esboçaram nenhum detalhe adicional em relação à pergunta, nem qualquer motivo ou qualquer explicação; fossem elas concordantes, discordantes ou parcialmente concordantes, atingindo o percentual de 27\%. O estudo realizando por Yen, Hirst e Hopkins (2007) é correlato com as pesquisas citadas, nos quais muitos dos argumentos utilizados são não teóricos.

\section{Figura 14 - Taxonomia Geral dos Argumentos Utilizados}

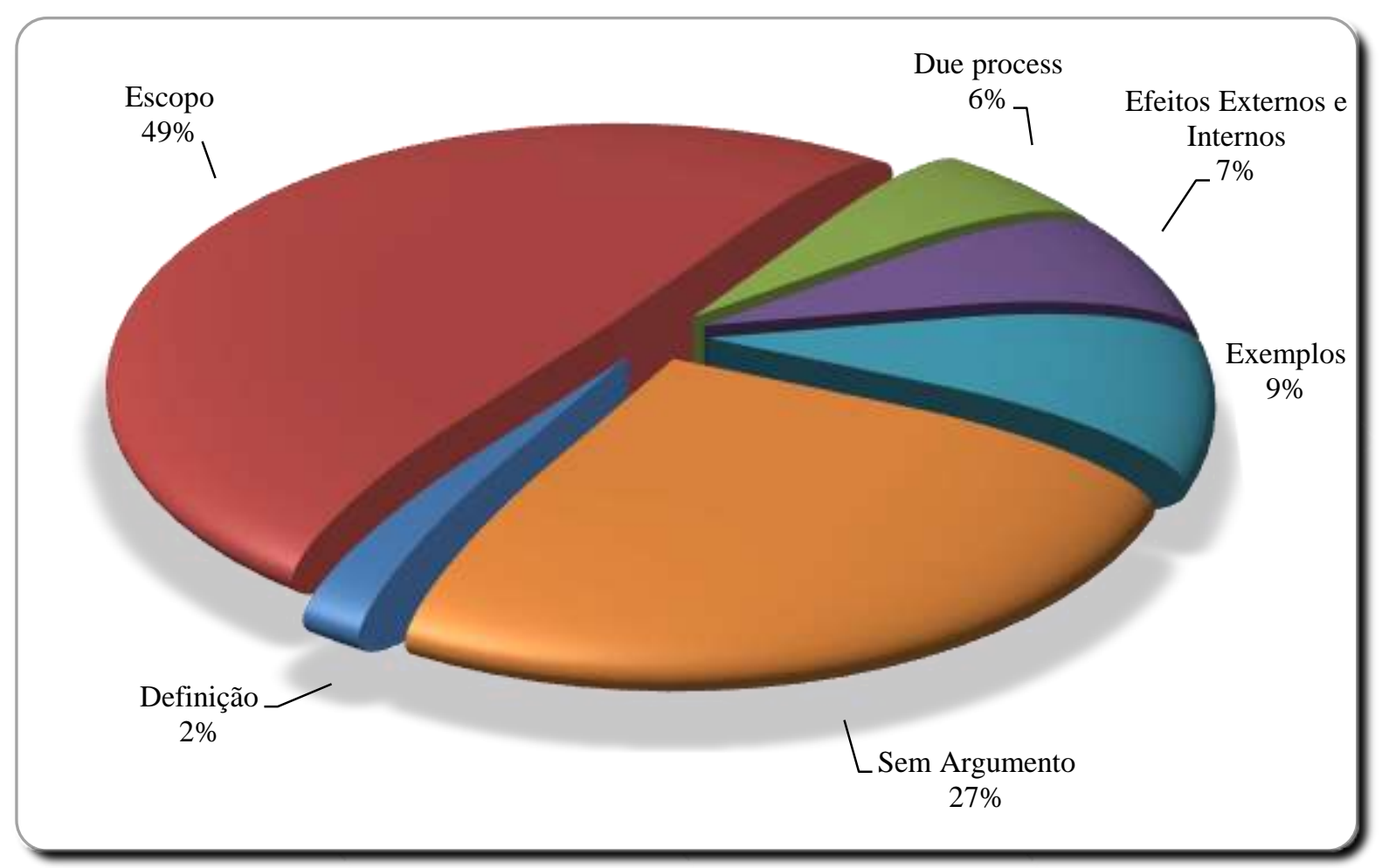

Fonte: Dados da Pesquisa

Ademais, sequencialmente os argumentos foram os da categoria exemplos, efeitos internos e externos ${ }^{51}$, due process e definição, respectivamente, auferindo os percentuais, $9 \%$, $7 \%, 6 \%$ e $2 \%$.

Suplementarmente, a Figura 15 evidencia a variabilidade dos argumentos utilizados no tocante à relação entre opinião geral e taxonomia dos argumentos. $\mathrm{O}$ objetivo foi verificar

51 Os argumentos do tipo Efeitos Internos e Efeitos Externos foram coligidos em um grupo único, Efeitos Internos e Externos. 
quais os tipos de argumentos utilizados pelos respondentes, para justificar suas respostas, se concordante, discordante ou concordante parcial.

As respostas concordantes foram justificadas por argumentos classificados, de acordo com a taxonomia, como os da categoria escopo (44,45\%), sem argumento (36,97\%), exemplos $(6,67 \%)$ e efeitos internos e externos (6,47\%). As justificativas para respostas discordantes utilizaram principalmente argumentos de escopo (61,43\%), exemplos $(12,18 \%)$, due process $(9,61 \%)$ e efeitos internos e externos $(7,98 \%)$, nesta ordem.

As respostas sem argumento (cerca de 95\%) ocorreram quando os respondentes concordavam com a questão proposta. Esse fato é justificado, porque os respondentes, na maioria das vezes em que discordavam - total ou parcialmente -, procuravam indicar o motivo para a discordância. Os demais argumentos foram utilizados em proporções convergentes, em relação ao tipo de taxonomia.

\section{Figura 15 - Relação entre a Opinião Geral e a Taxonomia dos Argumentos}

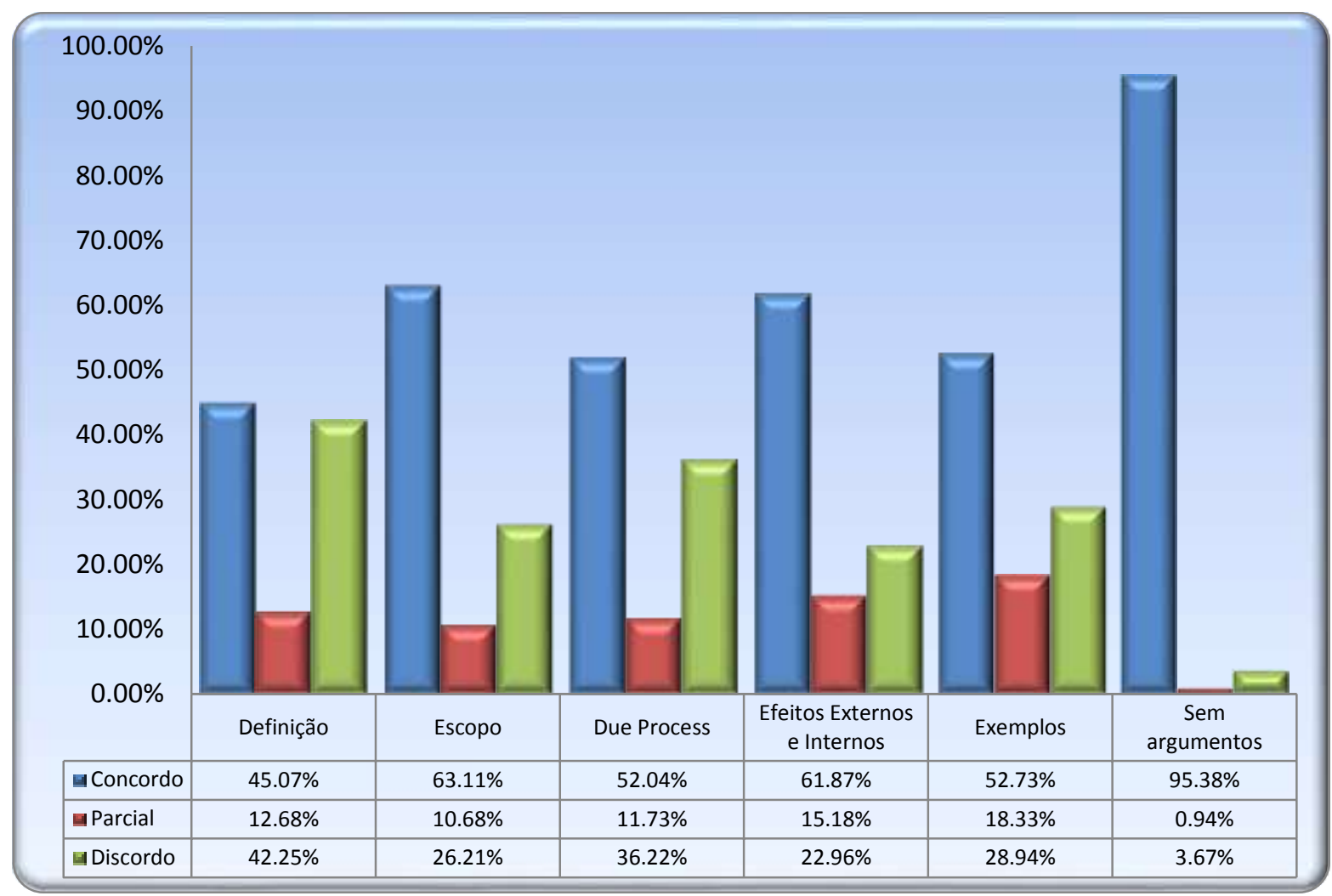

Fonte: Elaborado pelo autor, 2014

Complementarmente, com a finalidade de investigar se havia predomínio de qualquer tipo de argumento em relação aos demais, no tocante às justificativas citadas pelos respondentes das questões do DP/2013/1, foi realizada a análise das taxonomias dos argumentos por grupo (seção) 
de perguntas: introdução; elementos das demonstrações financeiras; orientações adicionais de apoio às definições de ativos e passivos; reconhecimento e desreconhecimento; definição de capital próprio e distinção entre passivos e instrumento de patrimônio; mensuração; apresentação e divulgação; apresentação na demonstração de resultados abrangentes e outras questões, conforme evidenciado na Tabela 14.

Observa-se similaridade nas escolhas dos pressupostos, no tocante às justificativas das opiniões dos respondentes, nas quais os argumentos classificados na categoria Escopo foram os mais utilizados em todas as seções. Excetuando-se as respostas sobre apresentação, que nessa pesquisa segue o mesmo comportamento das demais, o trabalho de Matos (2013) ${ }^{52}$ obteve o mesmo resultado.

Os argumentos classificados como efeitos externos e internos, foram utilizados principalmente nas seções: Introdução; Mensuração; Apresentação e Divulgação e Apresentação na Demonstração do Resultado Abrangente - Lucros e Perdas e Outros Resultados Abrangentes. Quanto àqueles categorizados como argumentos de exemplos, tiveram maior ênfase nas seções: Elementos dos Relatórios Financeiros; Orientação Adicional de Apoio as Definições de Ativo e Passivo; Definição de Patrimônio Líquido e Distinção de Passivo e Instrumento de Capital; Mensuração e Outras Questões.

Tabela 14 - Taxonomia dos Argumentos pelo Grupo de Análise

\begin{tabular}{|c|c|c|c|c|c|c|c|c|c|c|}
\hline & 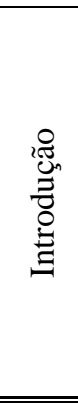 & 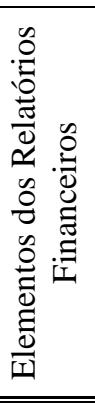 & 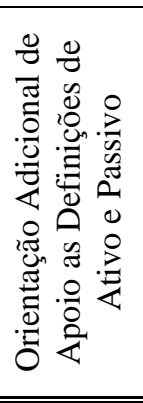 & 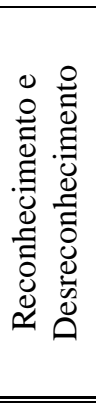 & 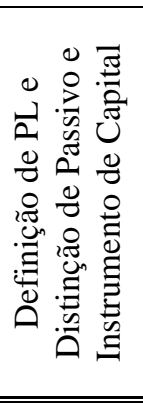 & 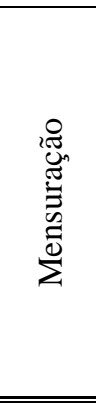 & 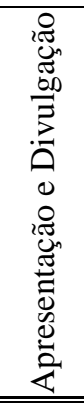 & 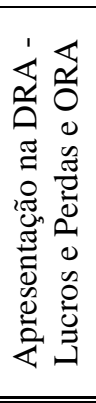 & 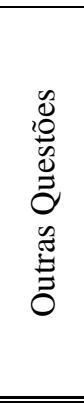 & $\Sigma$ \\
\hline Definição & 2 & 31 & 2 & 3 & 14 & 7 & 4 & 4 & 4 & 71 \\
\hline Escopo & 78 & 259 & 91 & 164 & 137 & 541 & 137 & 133 & 192 & 1732 \\
\hline Due process & 13 & 29 & 15 & 4 & 27 & 38 & 30 & 13 & 27 & 196 \\
\hline $\begin{array}{l}\text { Efeitos Externos e } \\
\text { Internos }\end{array}$ & 34 & 18 & 10 & 18 & 23 & 56 & 46 & 33 & 19 & 257 \\
\hline Exemplos & 5 & 54 & 25 & 15 & 27 & 104 & 26 & 27 & 28 & 311 \\
\hline Sem argumentos & 28 & 89 & 17 & 36 & 92 & 534 & 77 & 30 & 50 & 953 \\
\hline$\Sigma$ & 160 & 480 & 160 & 240 & 320 & 1280 & 320 & 240 & 320 & 3520 \\
\hline
\end{tabular}

Fonte: Dados da Pesquisa

${ }^{52}$ Para Matos (2013) o tipo de argumento mais utilizada nas questões sobre apresentação foi efeitos externos. 
A taxonomia due process foi utilizada com destaque na seção Definição de Patrimônio Líquido e Distinção de Passivo e Instrumento de Capital. Os argumentos de definição foram utilizados principalmente nos Elementos dos Relatórios Financeiros e Definição de Patrimônio Líquido e Distinção de Passivo e Instrumento de Capital. Em todas as seções analisadas, notou-se a ocorrência frequente de respostas sem justificativa - sem argumentos.

Por último, com o objetivo de identificar se existe diversidade de resposta - no que concerne à taxonomia dos argumentos - entre os setores de atuação, foi analisada a relação existente entre as respostas proferidas por cada setor de atuação, conforme Figura 16.

\section{Figura 16 - Relação entre a Taxonomia dos Argumentos e Setores de Atuação}

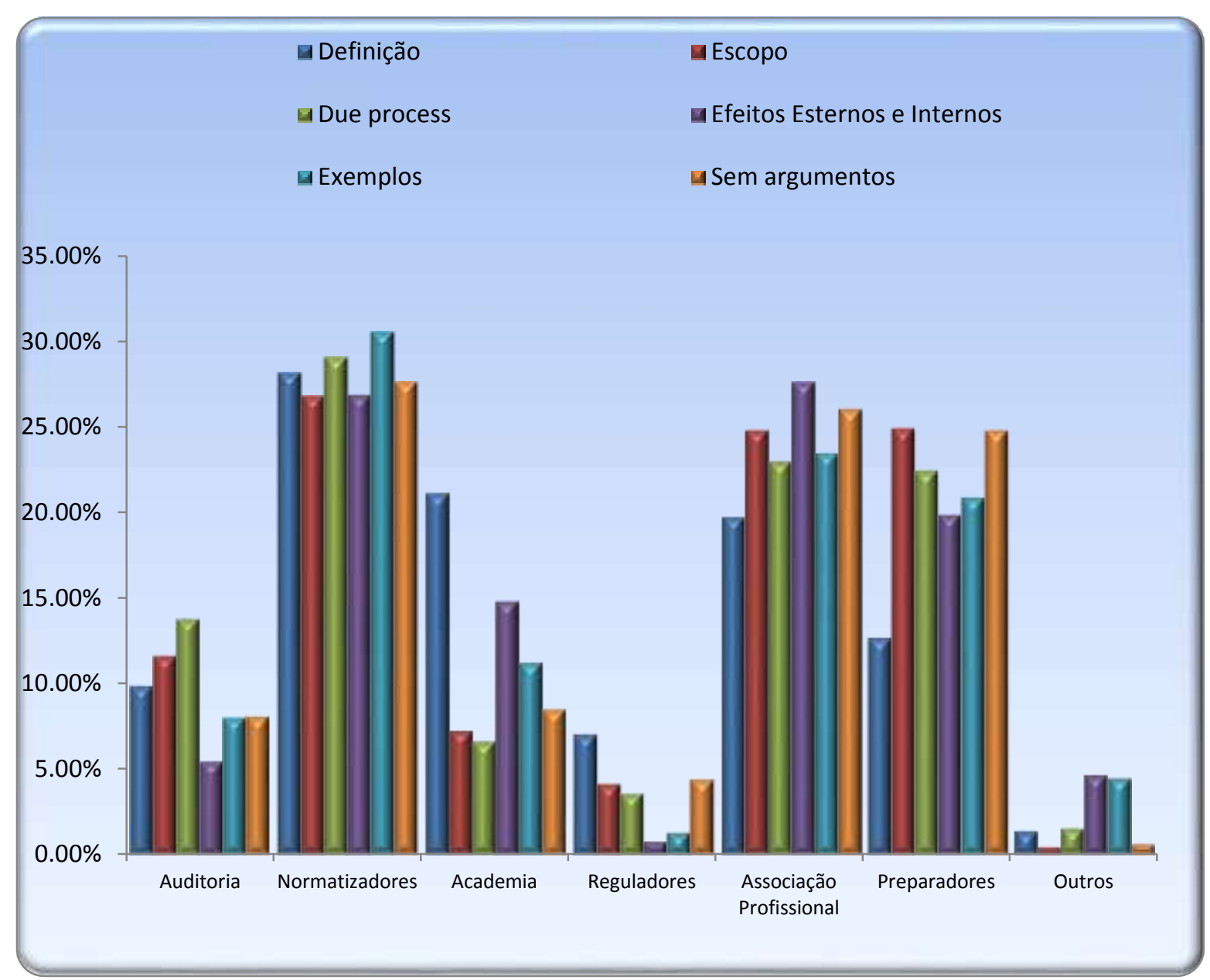

Fonte: Dados da Pesquisa

O comportamento dos argumentos, por setor de atuação, é convergente, entre a maioria das taxonomias utilizadas. Esse fato fica claro, quando se compara, a título de exemplo as taxonomias Escopo, Sem argumentos, Exemplos e Due process. A única inconsonância entre elas é o número de respostas, que oscila em detrimento de maior ou menor utilização de certas taxonomias, para efeito de justificativa das escolhas. 
Os normatizadores foram os que mais utilizaram argumentos classificados nas categorias: definição; escopo; due process; exemplos; e respostas sem argumento. Já o grupo associação profissional figurou em primeiro lugar na utilização dos argumentos classificados na categoria efeitos externos e internos. Esse fato se justifica pela maior número de cartas enviados desses setores.

Quanto efetuada a analise relativa - relação individual dos grupos e a taxonomia dos argumentos - evidencia-se comportamento padrão de respostas em que todos os grupos utilizaram primeiramente argumentos classificados como escopo, seguido de respostas sem argumentos, conforme Tabela 15. Por outro lado, a relação percentual mostra que os auditores foram os que mais utilizaram argumentos classificados na categoria escopo. Em 57,39\% das respostas dadas por esse grupo, utilizou-se argumentos classificados como escopo.

Os argumentos de definição e exemplos foram utilizados respectivamente em 4,87\% e $11,36 \%$ das respostas da academia (grupo que mais utilizou esses argumento em termos percentuais). As respostas sem argumentos foram utilizadas principalmente pelos preparadores e associação profissional, atingindo $28,23 \%$ e $28,18 \%$ respectivamente, das respostas dadas por esses grupos.

Tabela 15 - Relação entre a Taxonomia dos Argumentos e o Setor de Atuação

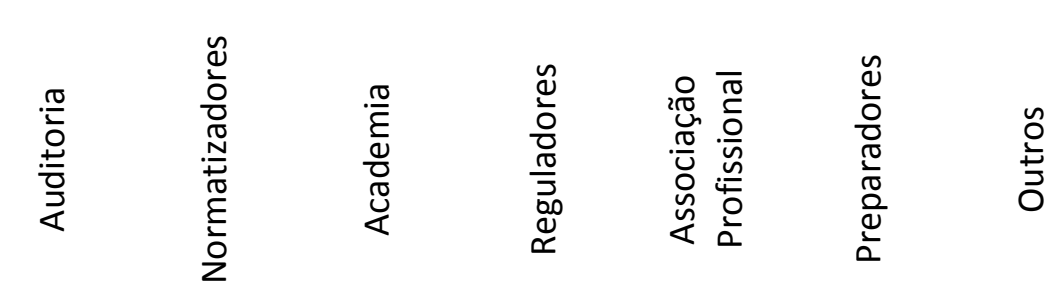

\begin{tabular}{lrrrrrrr}
\hline \hline Definição & $1,99 \%$ & $2,07 \%$ & $4,87 \%$ & $3,79 \%$ & $1,59 \%$ & $1,08 \%$ & $2,27 \%$ \\
\hline Escopo & $57,39 \%$ & $47,93 \%$ & $40,91 \%$ & $54,55 \%$ & $48,75 \%$ & $51,56 \%$ & $18,18 \%$ \\
\hline Due process & $7,67 \%$ & $5,89 \%$ & $4,22 \%$ & $5,30 \%$ & $5,11 \%$ & $5,26 \%$ & $6,82 \%$ \\
\hline $\begin{array}{l}\text { Efeitos Esternos e } \\
\text { Internos }\end{array}$ & $3,98 \%$ & $7,13 \%$ & $12,34 \%$ & $1,52 \%$ & $8,07 \%$ & $6,10 \%$ & $27,27 \%$ \\
\hline Exemplos & $7,10 \%$ & $9,81 \%$ & $11,36 \%$ & $3,03 \%$ & $8,30 \%$ & $7,78 \%$ & $31,82 \%$ \\
\hline Sem argumentos & $21,88 \%$ & $27,17 \%$ & $26,30 \%$ & $31,82 \%$ & $28,18 \%$ & $28,23 \%$ & $13,64 \%$ \\
\hline \multicolumn{1}{c}{$\Sigma$} & $100,00 \%$ & $100,00 \%$ & $100,00 \%$ & $100,00 \%$ & $100,00 \%$ & $100,00 \%$ & $100,00 \%$ \\
\hline F
\end{tabular}

Fonte: Dados da Pesquisa

Procedeu-se com o diagnóstico pormenorizado - seção por seção -, a fim de identificar as principais taxonomias utilizadas para cada seção, a relação das opiniões 
(concordo, discordo ou concordo parcial) com a taxonomia e o comportamento utilizado no tocante aos tipos de argumentos por pergunta.

\subsubsection{Introdução}

A Figura 17 revela a disposição dos argumentos utilizados no que se refere às perguntas da seção Introdução. A finalidade principal dessa análise é verificar se o comportamento individual - seção a seção - segue o comportamento da análise geral e em quais aspectos os respondentes se comportaram de maneira divergente - no tocante à taxonomia dos argumentos - quando expuseram suas opiniões e as fundamentaram através das premissas utilizadas.

\section{Figura 17 - Taxonomia dos Argumentos Utilizados - Introdução}

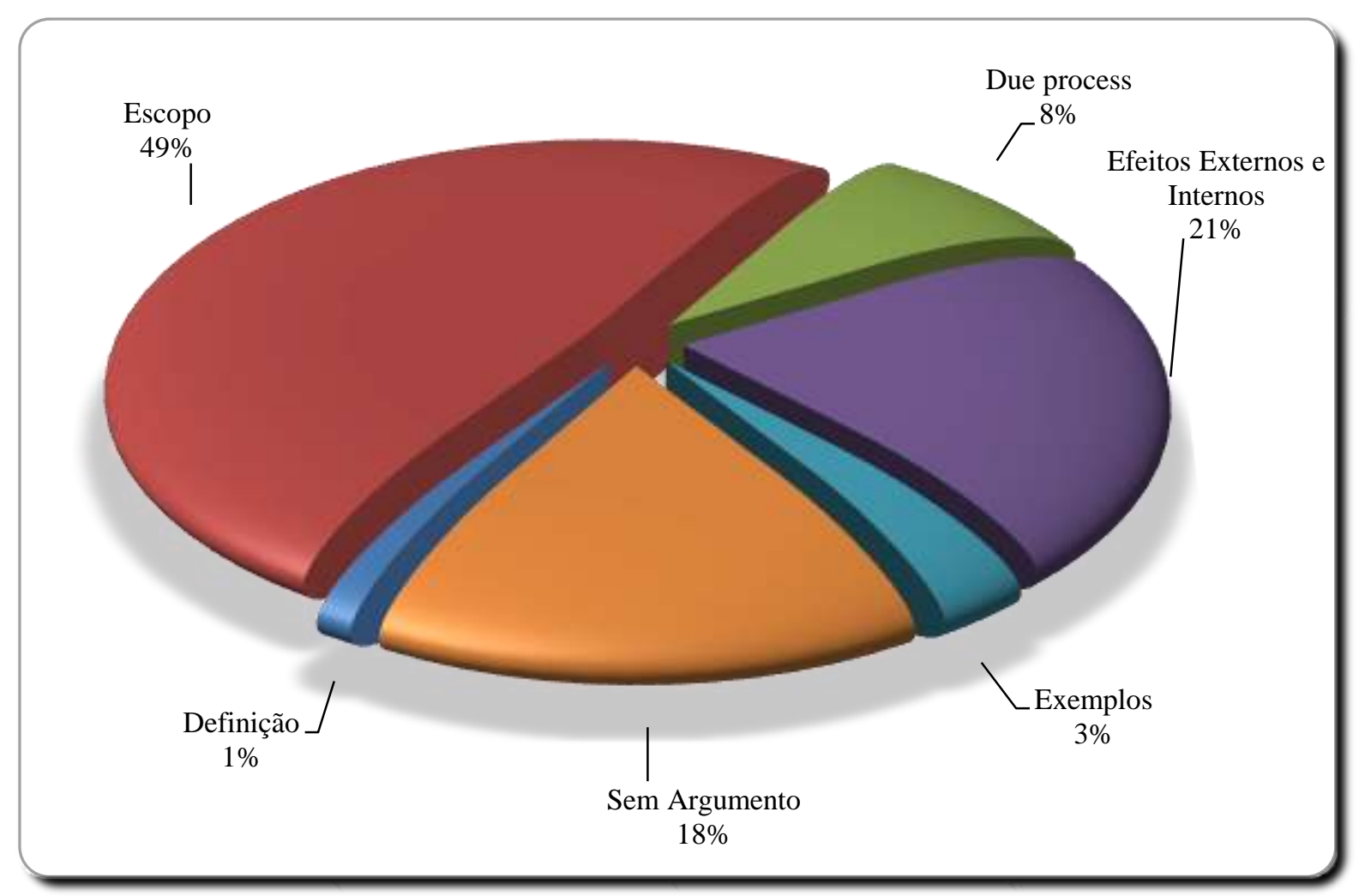

Fonte: Dados da Pesquisa

Para efeitos dessa seção, os argumentos classificados como escopo, foram os mais utilizados pelos respondentes, de forma similar à análise geral (49\%). Nesses argumentos os usuários demonstram sua opinião de forma prática, sem qualquer fundamentação teórica e 
simplesmente apoiam, com base no que entendem e o que pensam, a respeito dos pontos fortes e fracos e suas implicações para a contabilidade.

Adicionalmente, as demais categorias sofrem leves variações em sua utilização, em que, a título de exemplo, os argumentos classificados como efeitos internos e externos figuram em segundo lugar, totalizando $21 \%$ dos argumentos utilizados, evidenciando a elevação da utilização desse tipo de argumento nessa seção.

Esse fato é justificado pelas próprias características das perguntas da seção, pois conforme já explicado, essas questões trazem implicações diretas para os usuários da contabilidade, preparadores e normatizadores, visto que, principalmente no que diz respeito à questão número $1 \mathrm{~A}$, sobre o propósito principal da Estrutura Conceitual, muitos argumentaram acerca da importância desta para os usuários, normatizadores e preparadores, além do IASB.

Complementarmente aos pressupostos anteriores, a Figura 18 revela a opinião geral dos respondentes (concordante, discordante e parcialmente concordante) em relação à taxonomia dos argumentos utilizados.

Figura 18 - Relação da Opinião Geral com a Taxonomia do Argumento - Introdução A - Taxonomia das respostas concordantes

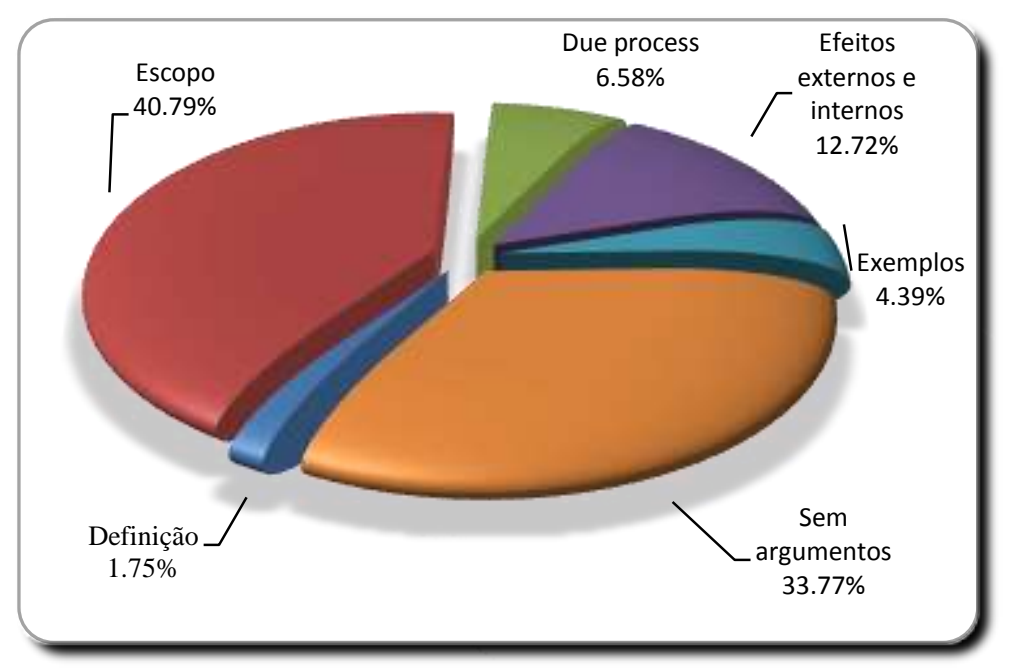


B - Taxonomia das respostas discordantes

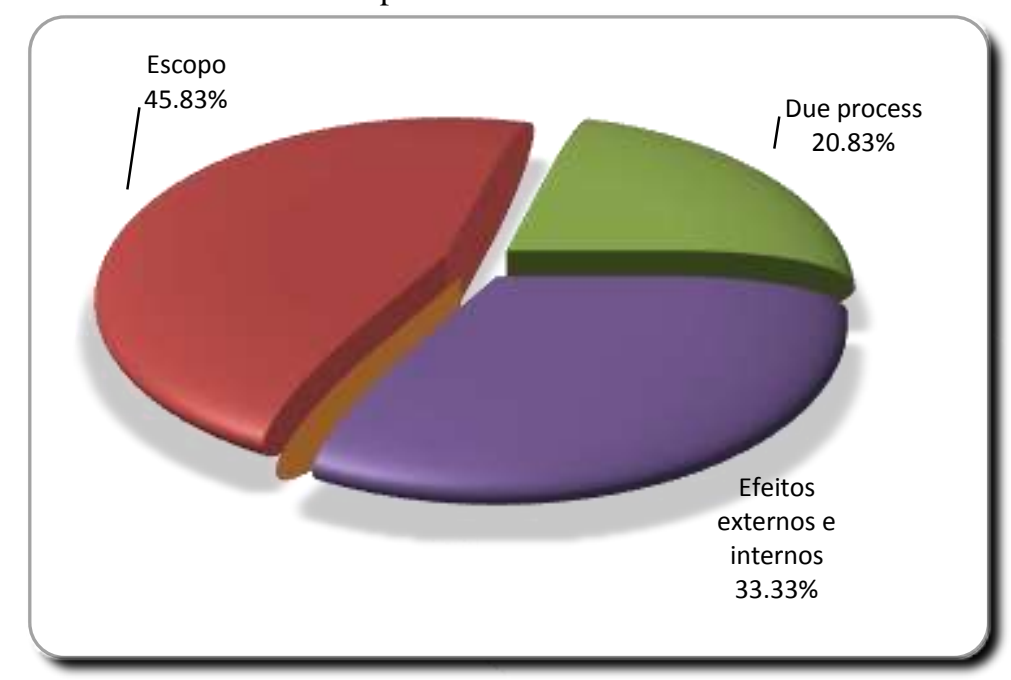

C - Taxonomia das respostas parcialmente concordantes

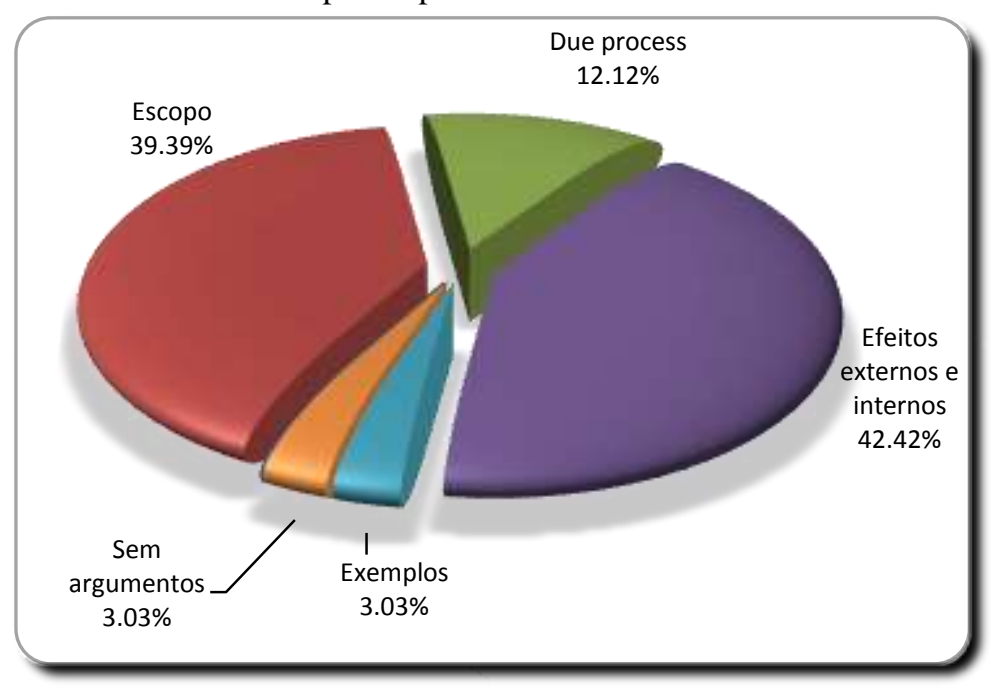

Fonte: Dados da Pesquisa

Constata-se conduta homogênea da taxonomia dos argumentos com base na opinião geral - exceto para as taxonomias Efeitos Externos e Internos e Due process. Os respondentes que fizeram uso de argumentos Efeitos Externos e Internos, o faziam, em sua maioria, quando discordavam ou quando concordavam parcialmente (ou discordavam parcialmente). Esse fato também é comprovado quando se analisa a taxonomia Due process, que é evidenciado o mesmo comportamento.

Analisando individualmente cada pergunta, é possível verificar claramente o comportamento dos respondentes em relação à taxonomia utilizada pergunta a pergunta. A Figura 19 evidencia a análise realizada referente à taxonomia dos argumentos por cada pergunta dentro da seção Introdução. 
Figura 19 - Relação da Opinião Geral com a Taxonomia do Argumento - Introdução

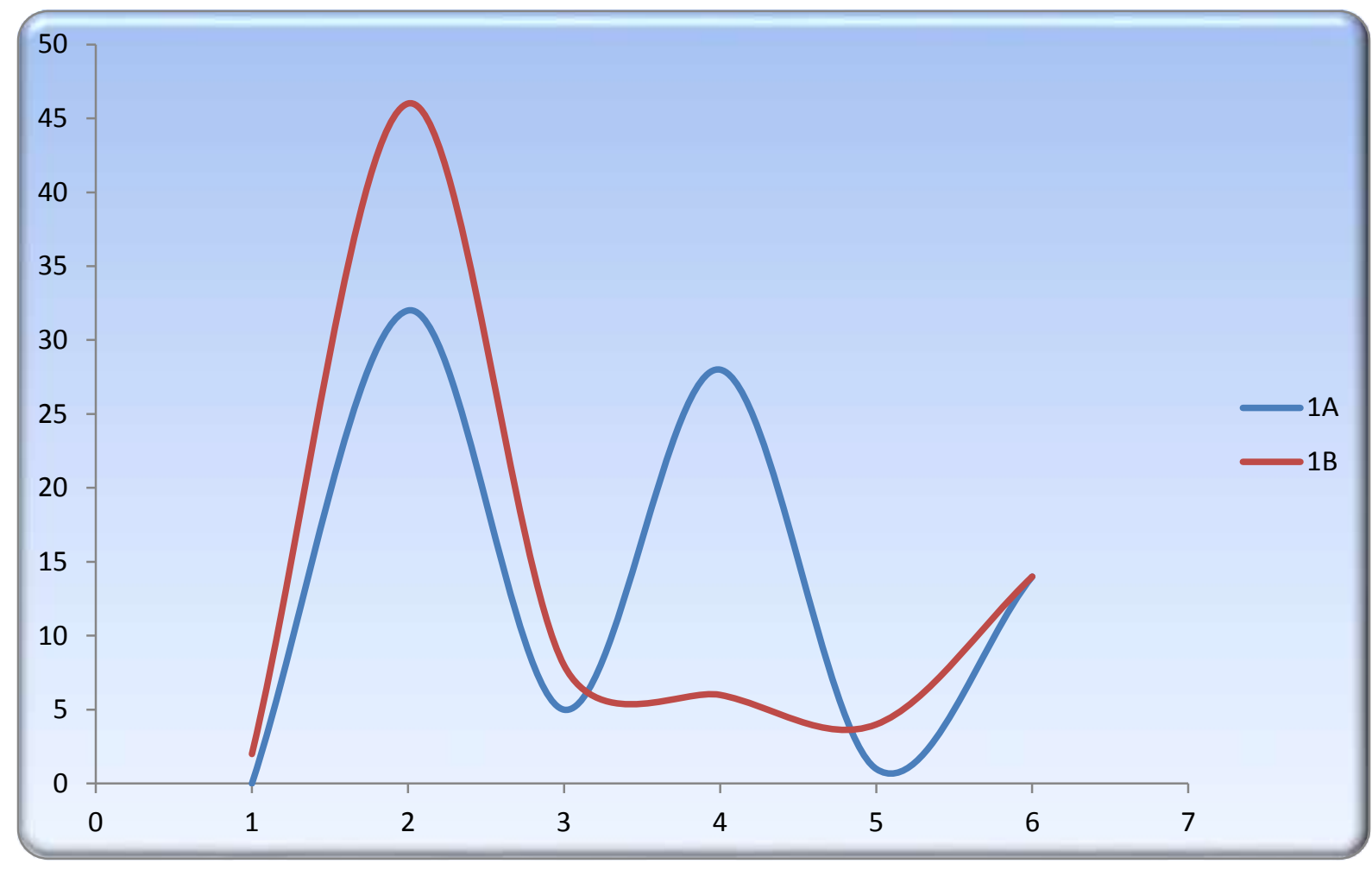

Nota: 1=Definição; 2=Escopo; 3=Duo Process; 4=Efeitos Externos e Internos; 5=Exemplos; 6=Sem Argumento Fonte: Dados da Pesquisa

Observa-se distinção entre os argumentos utilizados nas questões 1A e 1B. Parte considerável dos usuários, que discordavam ou concordavam parcialmente com a questão 1A, justificavam suas respostas mostrando as implicações para os usuários, preparadores e normatizadores, classificados em Efeitos Externos e Internos. Já em relação às respostas a pergunta 1B, elas foram justificadas em grande maioria pelos pressupostos de Escopo.

\subsubsection{Elementos de Relatórios Financeiros}

Quanto à taxonomia dos argumentos utilizados para a seção Elementos de Relatórios Financeiros, observa-se comportamento semelhante à análise geral, no que diz respeito a maior utilização de argumento classificado como Escopo, porém em proporções diferentes no que tange a participação das demais categorias taxonômicas.

Os usuários que comentaram as perguntas dessa seção, em sua maioria, optaram por argumentos Escopo, totalizando 54\% dos argumentos utilizados, conforme demonstrado na Figura 20. 
Figura 20 - Taxonomia dos Argumentos Utilizados - Elementos de Relatórios Financeiros

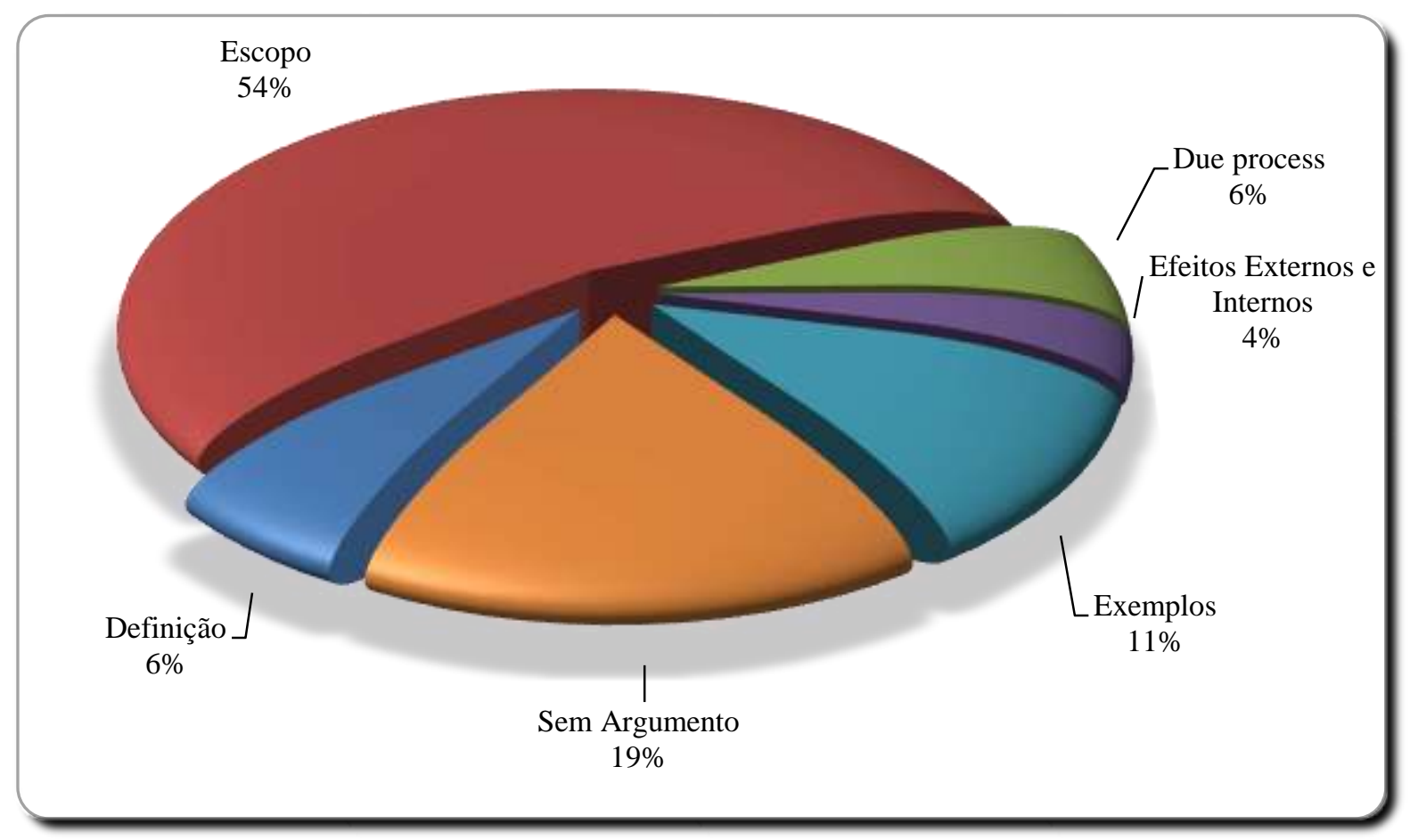

Fonte: Dados da Pesquisa

Percebe-se aumento substancial dos argumentos Escopo, acima dos valores obtidos na análise geral, demonstrando então maior participação no tocante as perguntas analisadas. Os argumentos de Exemplos e Definição também tiveram participações superiores à análise geral e os argumentos de Efeitos Internos e Externos e respostas sem argumentos foram menos utilizados nas perguntas acerca dos Elementos de Relatórios Financeiros.

$\mathrm{Na}$ sequência, como demonstrado na Figura 21, foram analisadas as opiniões gerais em relação à taxonomia dos argumentos. Percebe-se comportamento diversificado nos argumentos de Definição, Escopo e respostas Sem Argumento.

A maioria dos argumentos de Definição foram utilizados para justificar as respostas com opiniões discordantes da proposta do IASB. Já os argumentos de Escopo e respostas Sem Argumento, tiveram maior participação nos casos em que o respondente concordava com a premissa proposta. Os argumentos de exemplos tiveram a melhor distribuição, sendo que foi utilizado tanto em resposta em que os respondentes concordavam, quanto em respostas onde discordavam. Os demais grupos tiveram participações similares, sem maiores oscilações, sejam em relação às respostas concordantes, discordantes ou parcialmente concordantes. 
Figura 21 - Relação da Opinião Geral com a Taxonomia do Argumento - Elementos de Relatórios Financeiros

A - Taxonomia das respostas concordantes

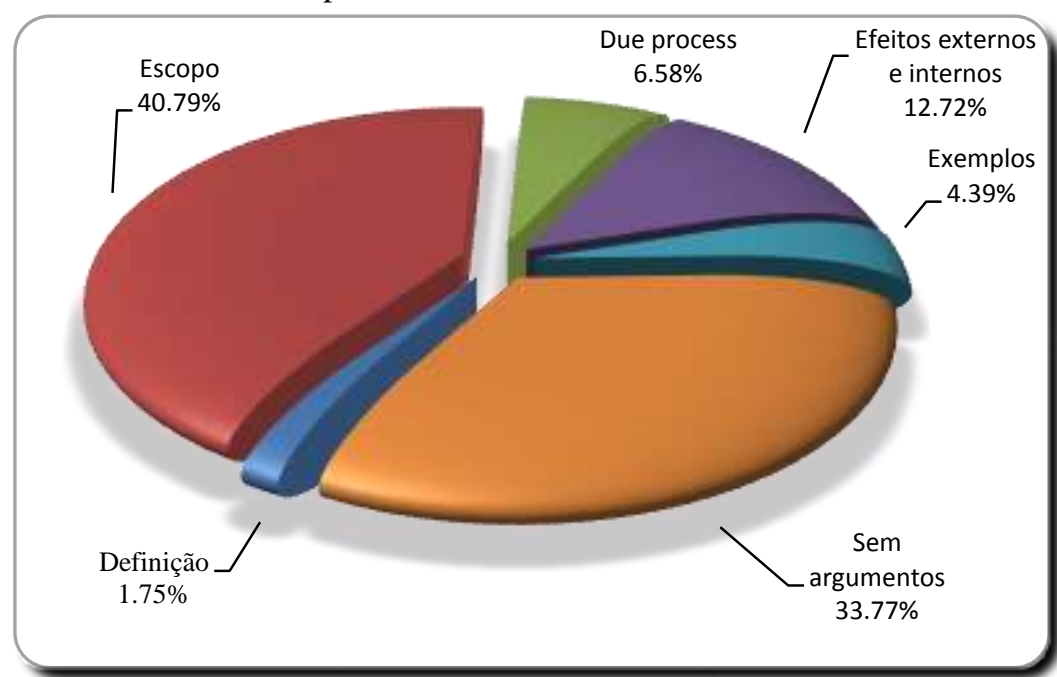

B - Taxonomia das respostas discordantes

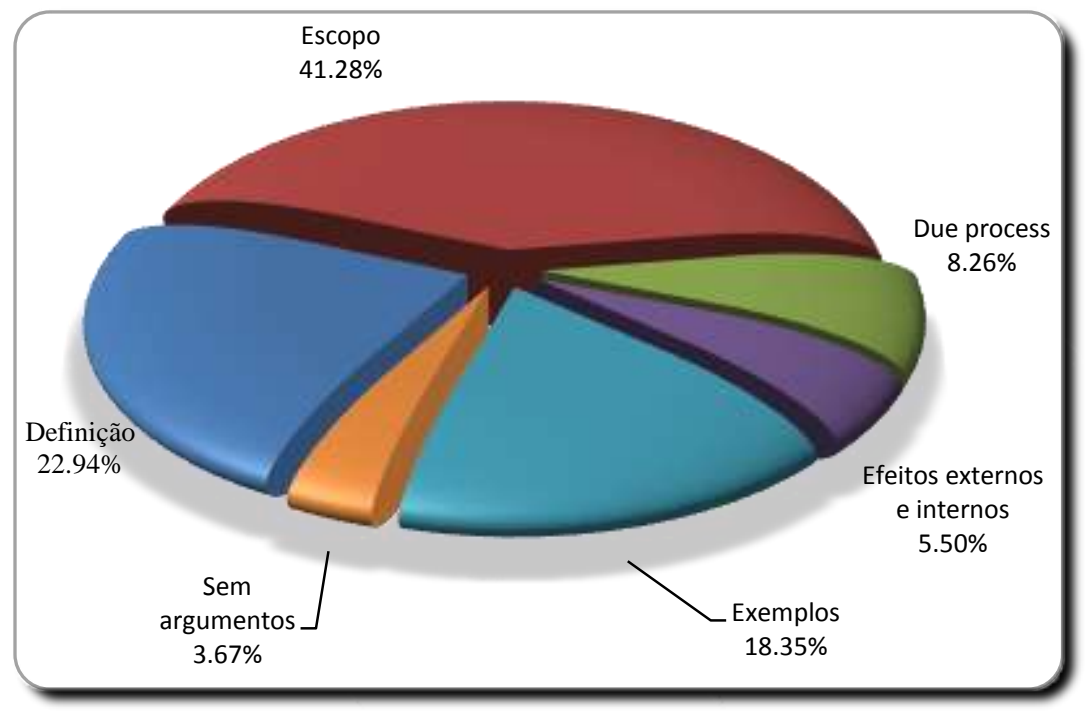

C - Taxonomia das respostas parcialmente concordantes

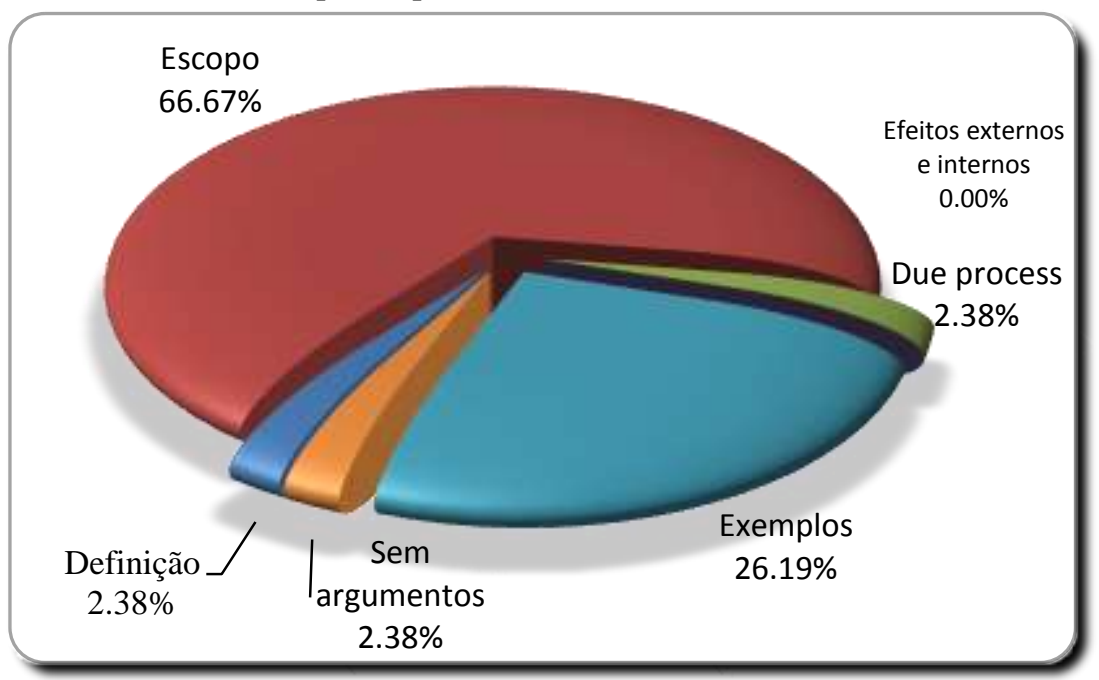

Fonte: Dados da Pesquisa 
Para verificar se o comportamento da seção seguia-se pergunta a pergunta, foi realizada análise delas, conforme evidenciado na Figura 22. Na maioria das perguntas, percebe-se comportamento semelhante na utilização dos argumentos conforme taxonomia, nas quais os fundamentos mais utilizados são os de Escopo, seguido de respostas Sem Argumento, exceto para as justificativas referentes à pergunta $2 \mathrm{~A}$. Nesse caso, além da utilização de argumentos de Escopo, ocorre boa representatividade dos argumentos classificados como Efeitos Externos e Internos.

$\mathrm{Na}$ maior parte dos casos - perguntas 2B (definição de passivo), 2C (definição de recurso econômico), 3A (não retenção da noção de que a entrada ou saída de fluxo de caixa é esperada), 3B (não definição do limite de probabilidade) e 3C (não manter a referência a probabilidade) - o comportamento é semelhante devido à proximidade das perguntas e até mesmo a natureza complementar entre elas, sendo que os respondentes geralmente utilizavam o mesmo tipo de argumento - taxonomia - com a finalidade de fundamentar a resposta fornecida nas perguntas propostas.

Figura 22 - Taxonomia dos Argumentos por Pergunta - Elementos de Relatórios Financeiros

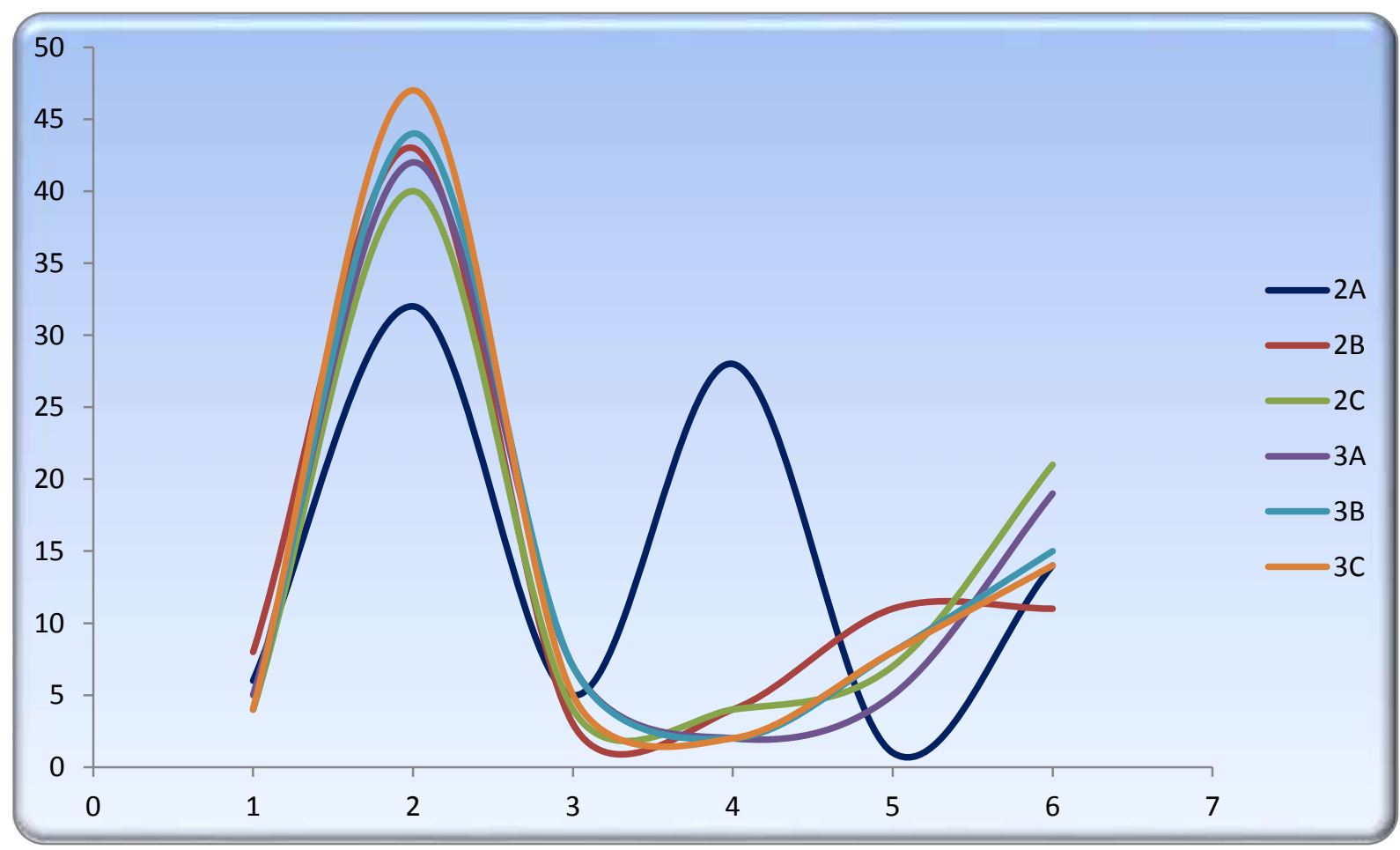

Nota: 1=Definição; 2=Escopo; 3=Duo Process; 4=Efeitos Externos e Internos; 5=Exemplos; 6=Sem Argumento Fonte: Dados da Pesquisa 


\subsubsection{Orientação Adicional de Apoio as Definições de Ativo e Passivo}

De forma semelhante à seção Elementos de Relatórios Financeiros, a seção Orientação Adicional de Apoio às Definições de Ativo e Passivo teve expressiva participação dos argumentos Escopo, totalizando 57\% dos argumentos utilizados na seção (comportamento superior à análise geral). A segunda maior representatividade foram os argumentos de Exemplos, seguidos pelas respostas Sem Argumento.

Figura 23 - Taxonomia dos Argumentos Utilizados - Orientação Adicional de Apoio as Definições de Ativo e Passivo

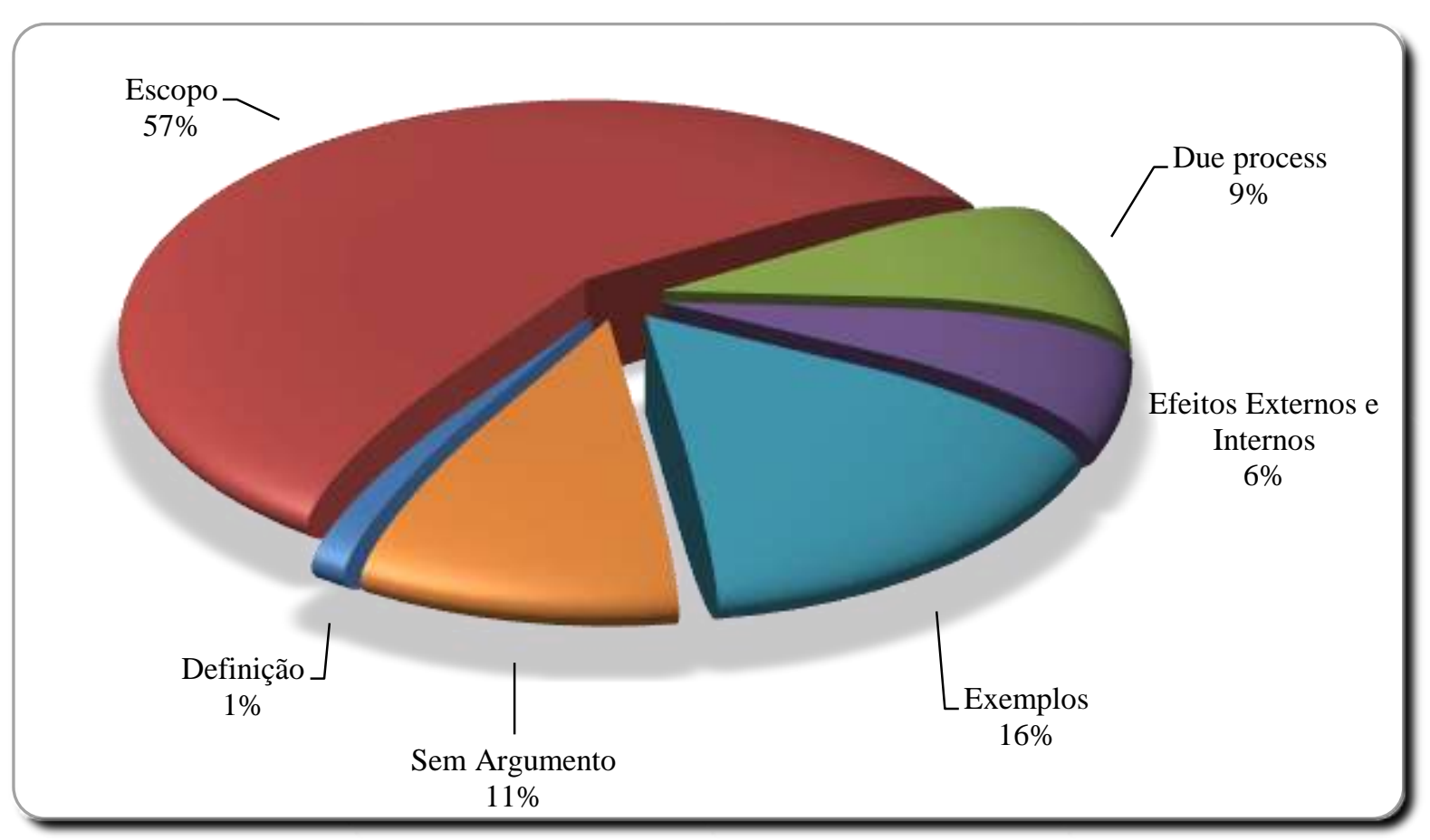

Fonte: Dados da Pesquisa

É evidente o aumento dos argumentos classificados como Escopo e Exemplos em detrimento dos demais. A Figura 24 complementa essa análise e indica à similaridade da taxonomia utilizada, se concordante, discordante ou concordante parcial, em que eram mais utilizados em respostas concordantes, exceto para os argumentos classificados na taxonomia Definição, em que mesmo sendo pouco utilizada, o fez de igual modo para as respostas concordantes e parcialmente concordantes.

As categorias efeitos externos e internos e respostas sem argumentos foram utilizadas em sua totalidade quando os respondentes concordavam com a proposta do IASB para essa 
seção. As categorias escopo, due process e exemplos foram utilizadas, em maioria, para justificar respostas concordantes.

A Figura 25 refere-se à exposição individual das perguntas das seções, que complementa os pressupostos anteriores e evidencia o mesmo comportamento entre as duas perguntas, para as quais os tipos de argumentos utilizados seguem-se de forma padrão.

Figura 24 - Relação da Opinião Geral com a Taxonomia do Argumento - Orientação Adicional de Apoio as Definições de Ativo e Passivo

A - Taxonomia das respostas concordantes

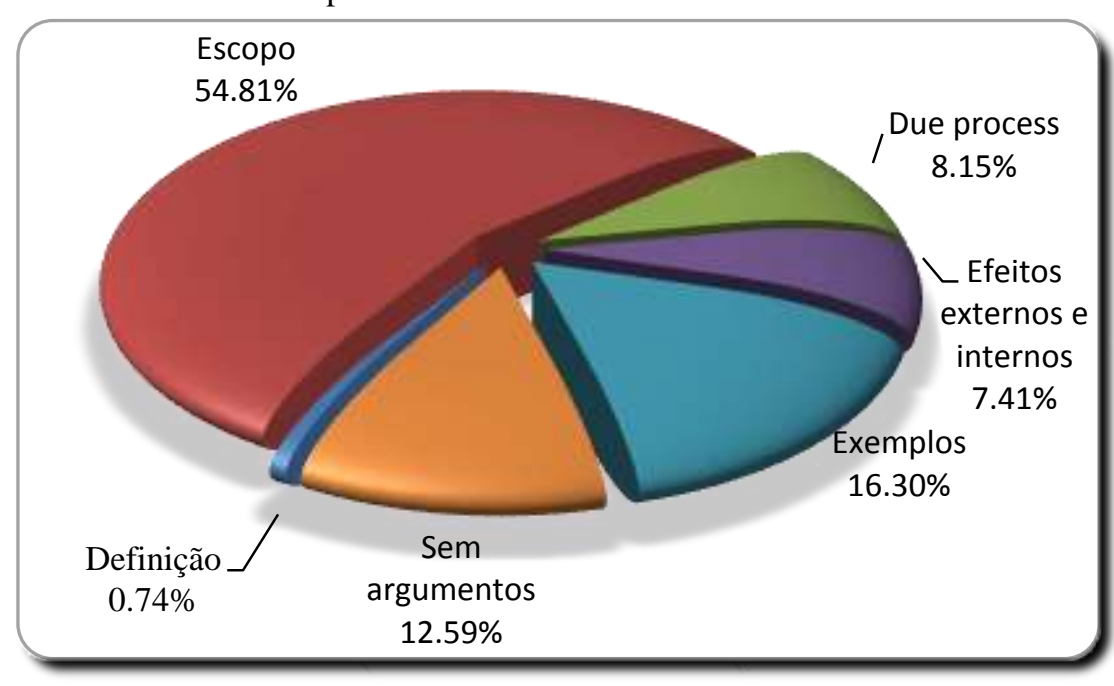

B - Taxonomia das respostas discordantes

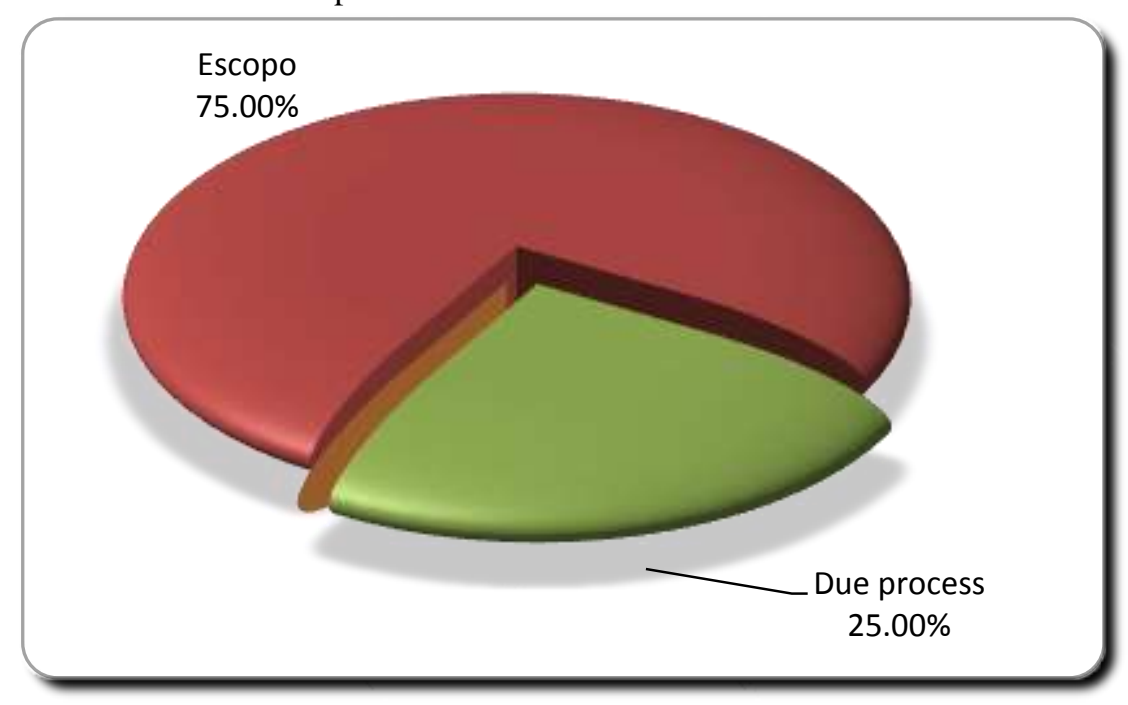


C - Taxonomia das respostas parcialmente concordantes

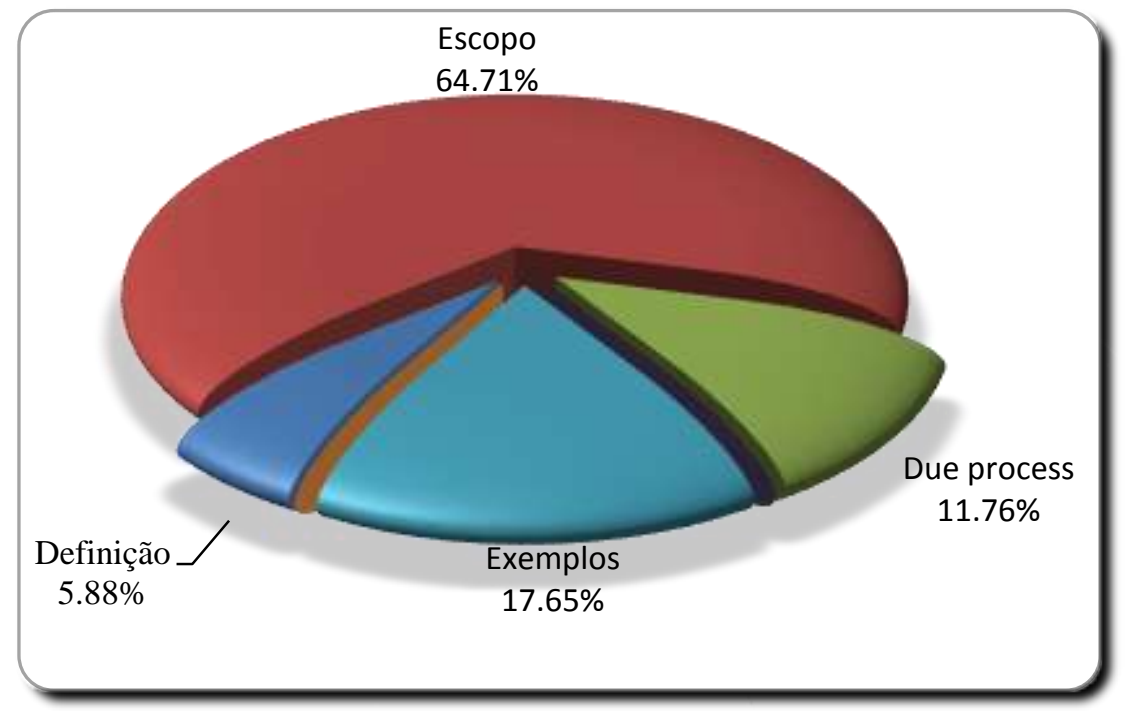

Fonte: Dados da Pesquisa

Figura 25 - Taxonomia dos Argumentos por Pergunta - Orientação Adicional de Apoio as Definições de Ativo e Passivo

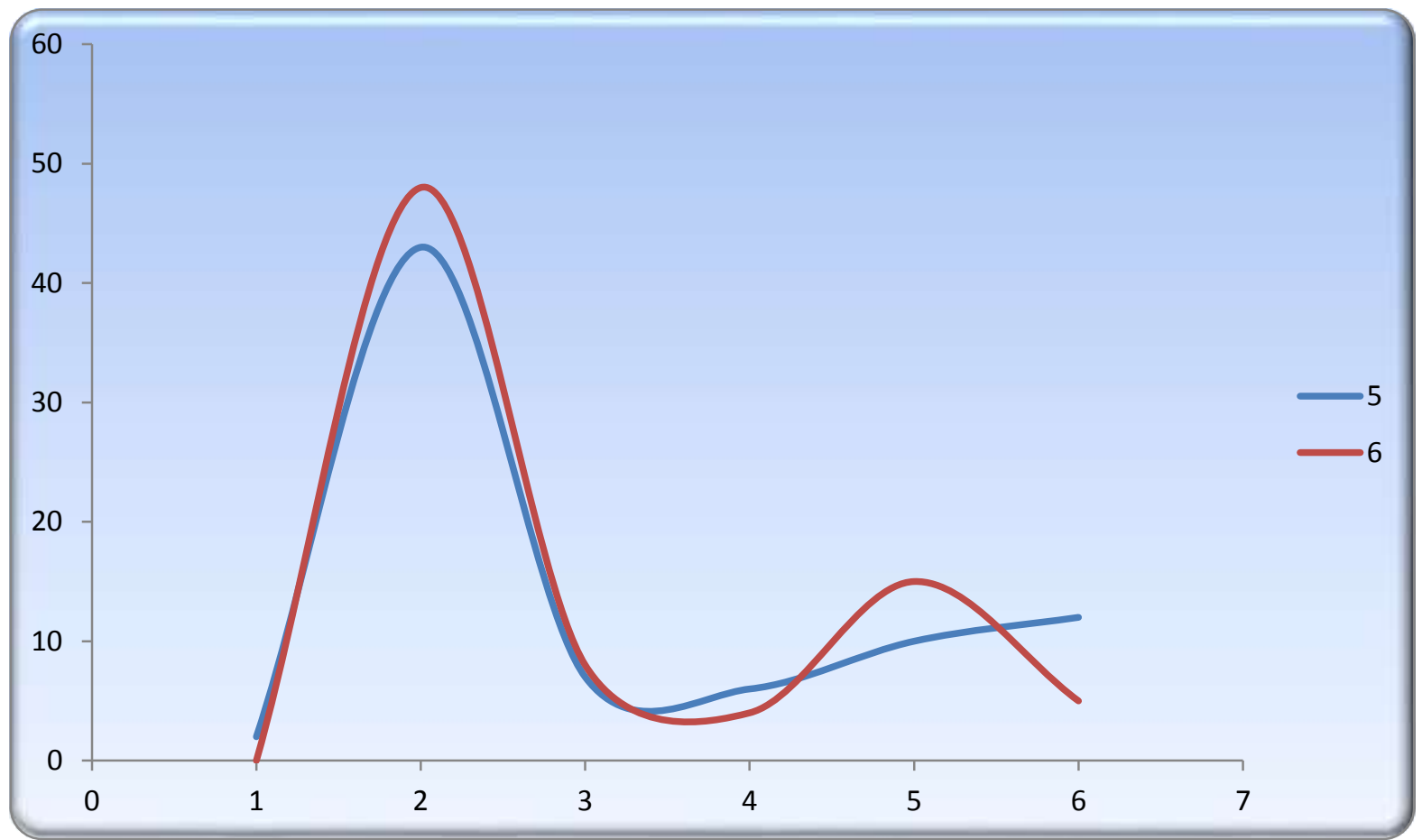

Nota: 1=Definição; 2=Escopo; 3=Duo Process; 4=Efeitos Externos e Internos; 5=Exemplos; 6=Sem Argumento Fonte: Dados da Pesquisa

\subsubsection{Reconhecimento e Desreconhecimento}

No tocante às perguntas sobre Reconhecimento e Desreconhecimento, a Figura 26 mostra a distribuição dos pressupostos dados para as perguntas. Observa-se comportamento 
diferente no que diz respeito aos percentuais de participação dos grupos taxonômicos. A maior representatividade dos argumentos de Escopo ocorreu nessa seção, totalizando 68\% dos argumentos, inclusive acima da análise geral. Apesar da redução em relação à análise geral, a segunda maior representatividade foram as respostas Sem Argumento.

Figura 26 - Taxonomia dos Argumentos Utilizados - Reconhecimento e Desreconhecimento

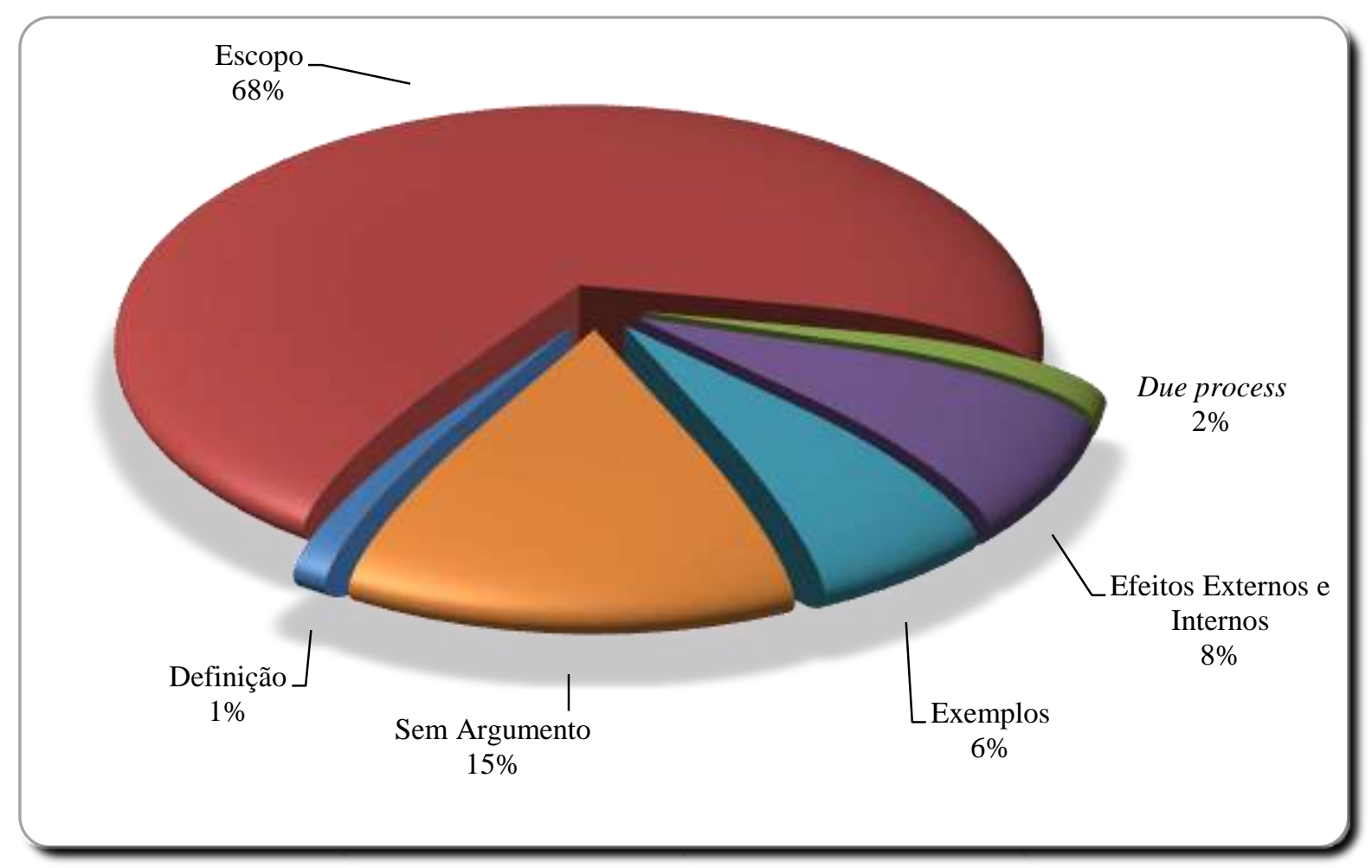

Fonte: Dados da Pesquisa

Os argumentos de Definição, Exemplos e Due process tiveram reduções em relação à análise geral, sendo que esse fato se deve a maior utilização dos argumentos classificados como Escopo. Os resultados evidenciados nessa seção são bastante similares aos achados de Matos (2013) para reconhecimento de Leasing, inclusive aquela pesquisa atingiu o mesmo percentual para os argumentos de Escopo (68\%), tendo em segundo lugar as respostas sem argumentos.

Quanto à relação entre categorias taxonômicas e a opinião dos respondentes, a Figura 27 destaca que a maioria das respostas concordantes, as justificativas foram classificadas como argumentos de Escopo e respostas sem argumentos. As categorias Due process e Efeitos Externos e Internos, mesmo sendo pouco utilizadas, foram utilizadas para, na maioria das vezes, justificar respostas discordantes e parcialmente concordantes. A categoria 
definição, apesar de pouco utilizada em números relativos, em sua totalidade foi utilizada quando os respondentes concordavam com a proposta do IASB.

Figura 27 - Relação da Opinião Geral com a Taxonomia do Argumento - Reconhecimento e Desreconhecimento

A - Taxonomia das respostas parcialmente concordantes

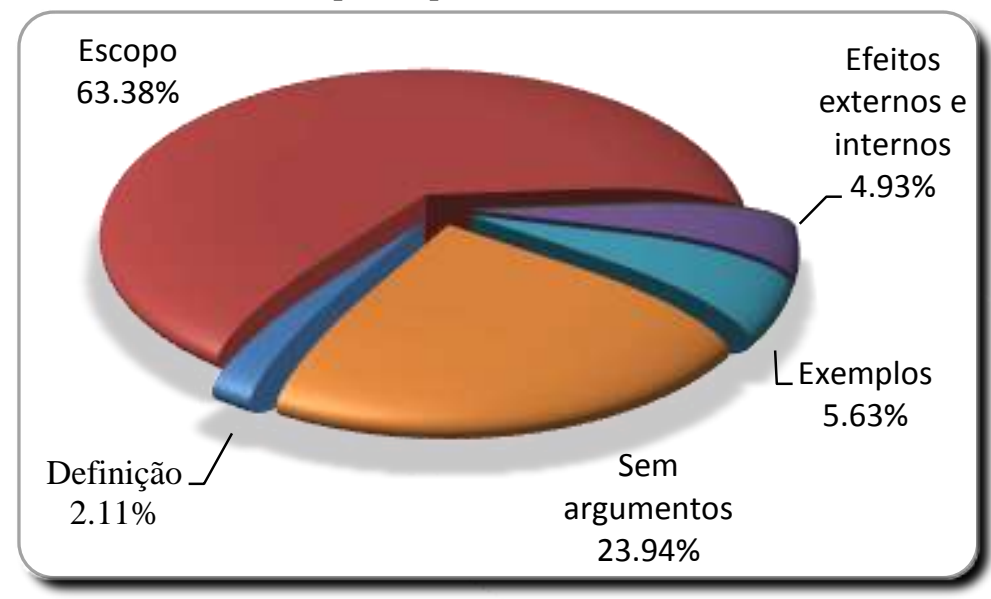

B - Taxonomia das respostas discordantes

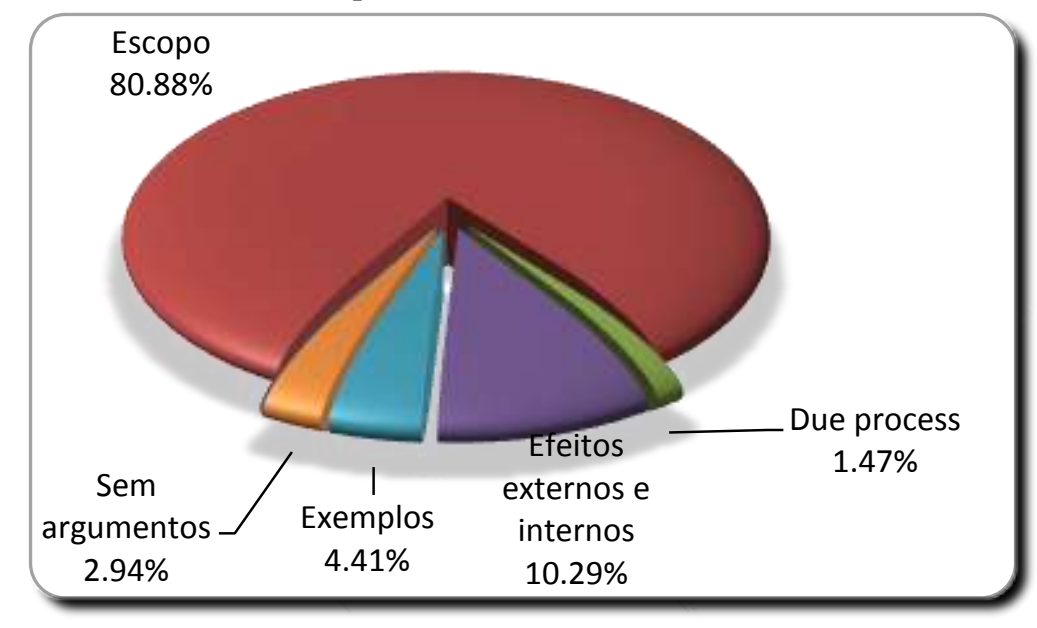

C - Taxonomia das respostas parcialmente concordantes

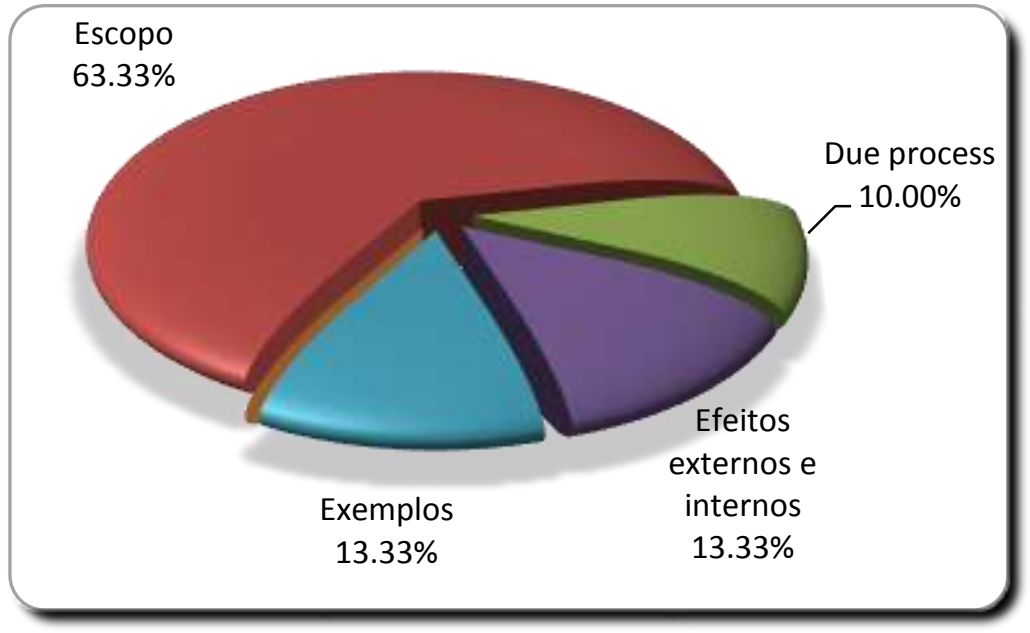

Fonte: Dados da Pesquisa 
Em relação à análise individualizada das perguntas, conforme evidenciado na Figura 28, percebe-se padrões de comportamento em relação aos argumentos dados. Novamente os achados são análogos aos encontrados por Matos (2013). Se analisarmos as respostas das perguntas 8A (a entidade deve reconhecer todos os seus ativos, a menos que a informação não seja relevante) e 8B (a entidade deve reconhecer todos os seus ativos, a menos que a informação não seja uma representação fiel) perceberemos que elas quase se sobrepõe.

Figura 28 - Taxonomia dos Argumentos por Pergunta - Reconhecimento e Desreconhecimento

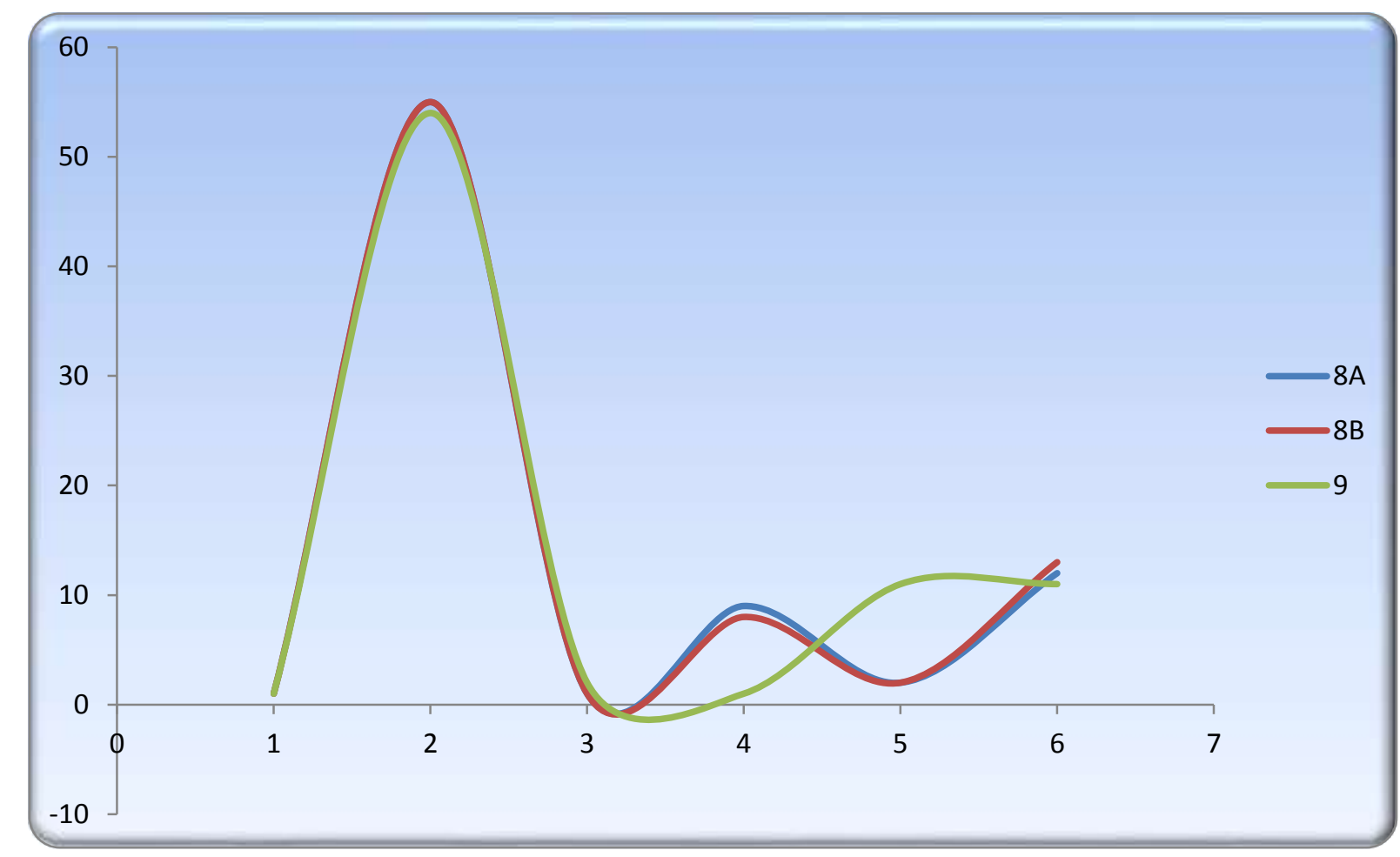

Nota: 1=Definição; 2=Escopo; 3=Due Process; 4=Efeitos Externos e Internos; 5=Exemplos; 6=Sem Argumento Fonte: Dados da Pesquisa

Esse fato se deve à proximidade entre as questões, isto é, aspecto complementar entre uma e outra, e, dessa forma, poucos respondentes concordaram com uma e discordaram da outra (vice-versa) e frequentemente utilizavam argumentos similares para essas questões.

\subsubsection{Definição de PL e Distinção de Passivo e Instrumento de Capital}

No que tange ao diagnóstico da seção Definição de Patrimônio Líquido e Distinção de Passivo e Instrumento de Capital, prevaleceram os argumentos de Escopo em detrimento dos demais, porém obtendo percentuais diferentes das demais seções. Nesse caso, os argumentos 
de Escopo atingiram o menor percentual em comparação com as demais seções, tendo em vista que houve melhor distribuição dos argumentos entre as categorias taxonômicas.

Figura 29 - Taxonomia dos Argumentos Utilizados - Definição de PL e Distinção de Passivo e Instrumento de Capital

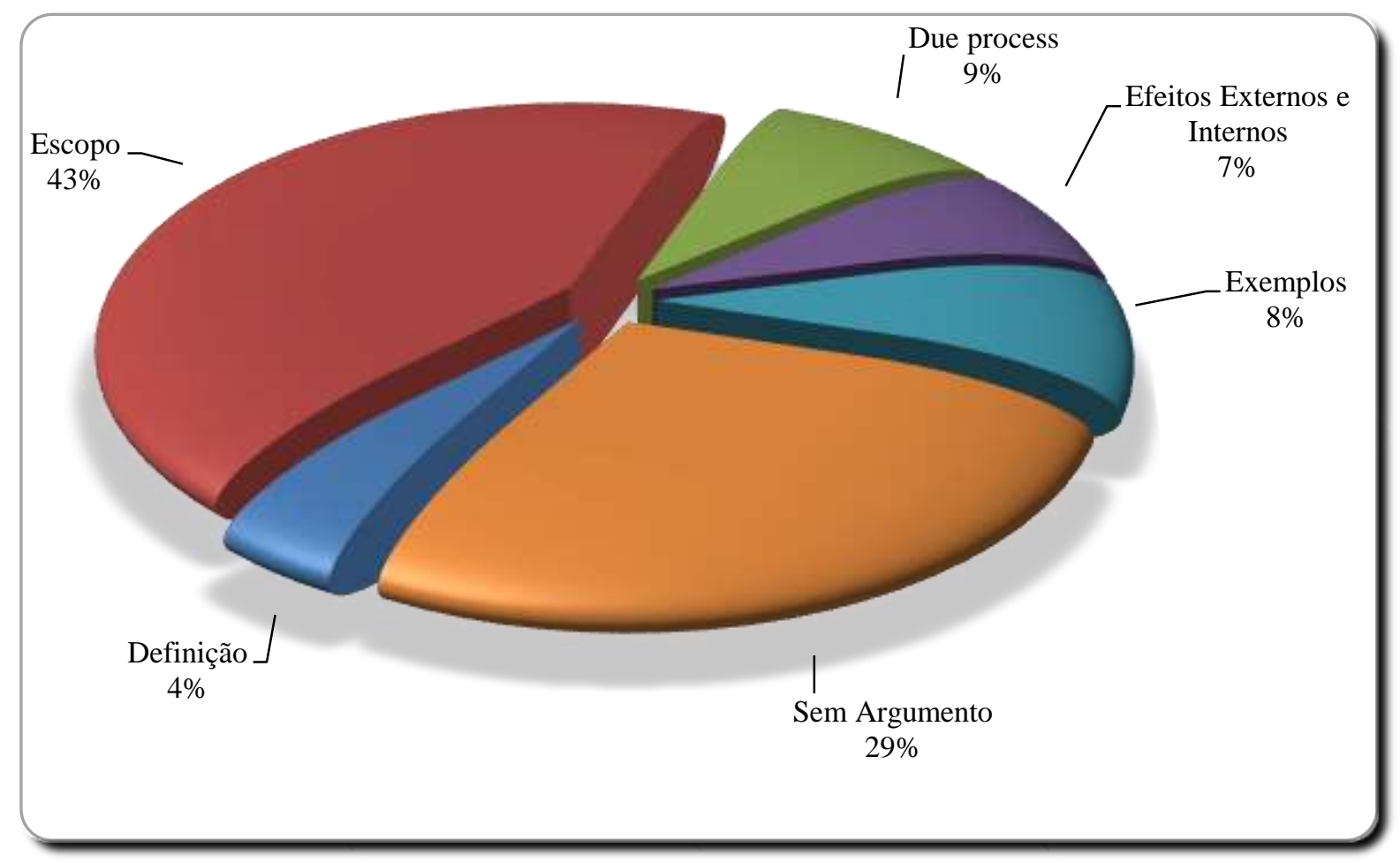

Fonte: Dados da Pesquisa

Além disso, foi perceptível o aumento das respostas sem argumento, alcançando percentual acima da análise geral, a qual totalizou 27\%. Quanto à relação entre taxonomia e a opinião dos respondentes, a Figura 30 destaca a distição entre as respostas e os argumentos dados.

A maioria das respostas concordantes foram justificadas por meio de argumentos classificados como Escopo ou Sem Argumento, inclusive, os argumentos de Escopo e respostas sem argumento - quando ocorriam - eram utilizadas em respostas concordantes. 
Figura 30 - Relação da Opinião Geral com a Taxonomia do Argumento - Definição de PL e Distinção de Passivo e Instrumento de Capital

A - Taxonomia das respostas concordantes

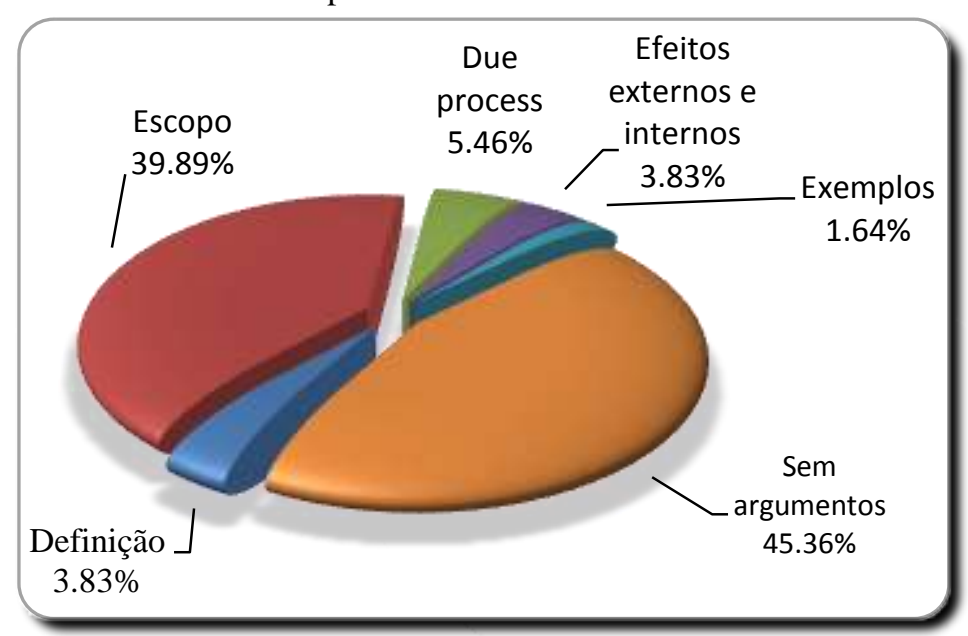

B - Taxonomia das respostas discordantes

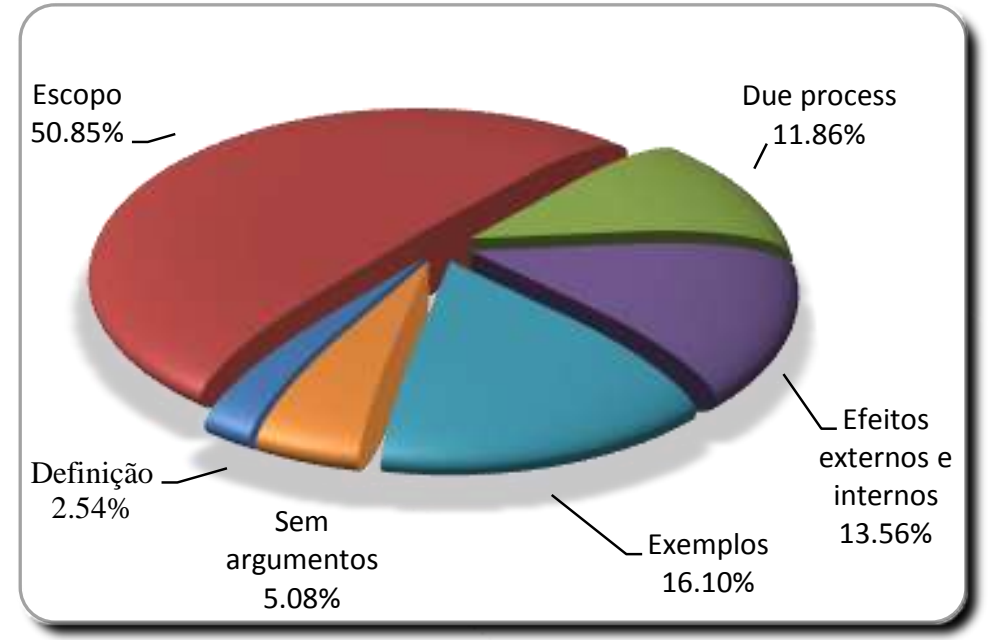

C - Taxonomia das respostas parcialmente concordantes

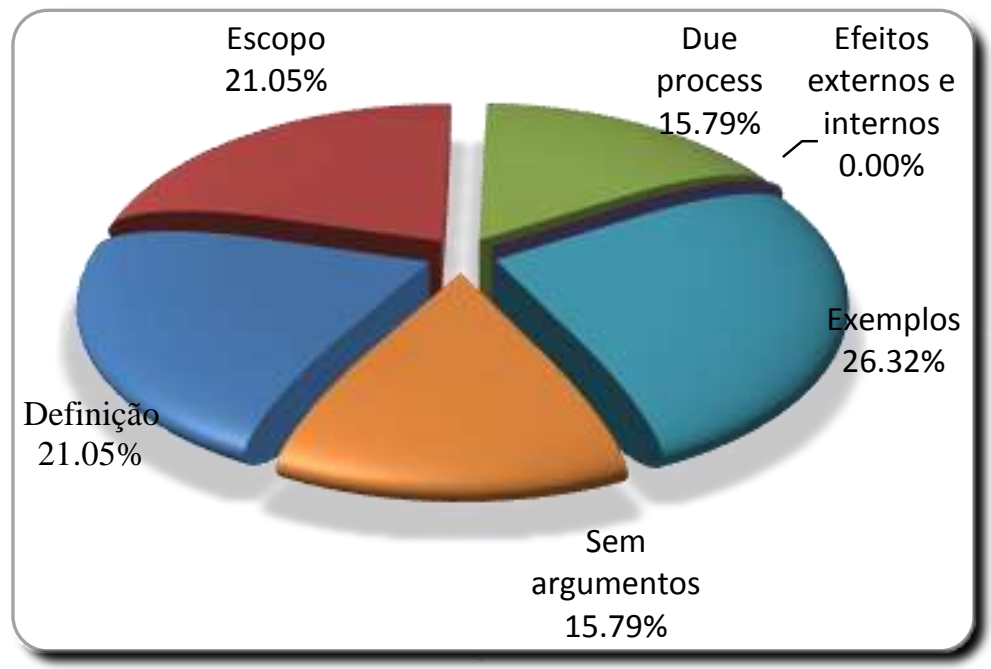

Fonte: Dados da Pesquisa 
Por outro lado, as taxonomias Due process, Efeitos Externos e Internos e Exemplos, quando utilizadas, eram para justificar respostas discordantes ou parcialmente concordantes. Quando investigamos as taxonomias pergunta a pergunta, percebemos a existência de padrão nas respostas, em que apenas leves variações podem ser observadas.

As respostas às perguntas 10C e 10D utilizaram mais argumentos de Escopo do que as demais. No tocante à $10 \mathrm{~A}$, obtiveram-se mais respostas sem argumentos e a pergunta $10 \mathrm{~B}$ obteve mais justificativas classificadas como Due process.

Figura 31 - Taxonomia dos Argumentos por Pergunta - Definição de PL e Distinção de Passivo e Instrumento de Capital

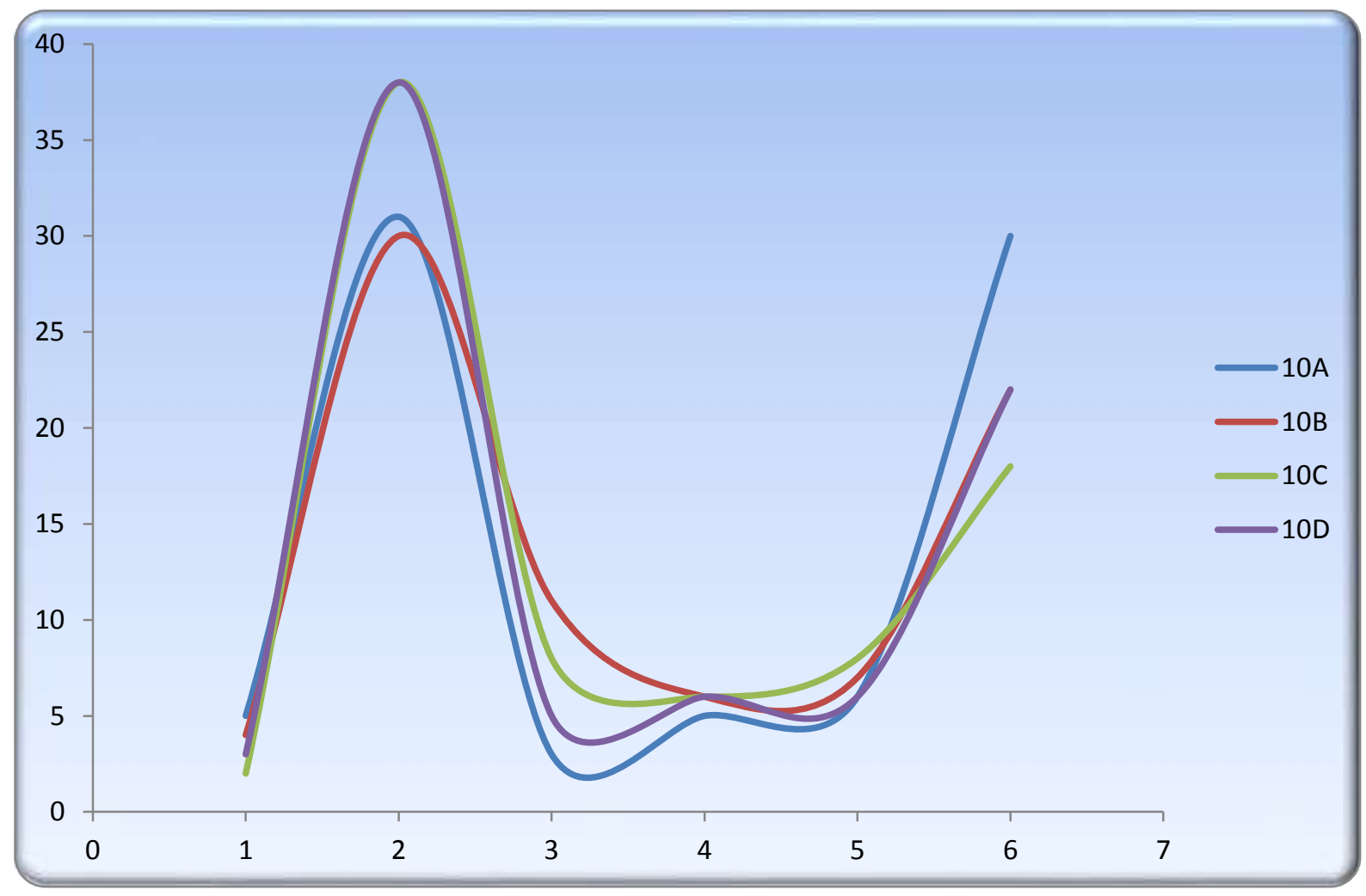

Nota: 1=Definição; 2=Escopo; 3=Due Process; 4=Efeitos Externos e Internos; 5=Exemplos; 6=Sem Argumento Fonte: Dados da Pesquisa

\subsubsection{Mensuração}

Para as perguntas sobre Mensuração - aquelas com o maior número de questões analisadas - foi identificado aumento significativo nas respostas Sem Argumento, fazendo com que essas se igualassem à quantidade de respostas com argumentos classificados como Escopo, como demonstrado na Figura 32. 
Além disso, essa seção foi a que obteve o menor percentual dos argumentos de Escopo (em comparação com as demais seções analisadas) 42\%, abaixo dos valores obtidos na análise geral. A ascensão das respostas Sem Argumento em partes se dá pelo elevado nível de respostas concordantes atingido nessa seção $(75,55 \%)$.

Figura 32 - Taxonomia dos Argumentos Utilizados - Mensuração

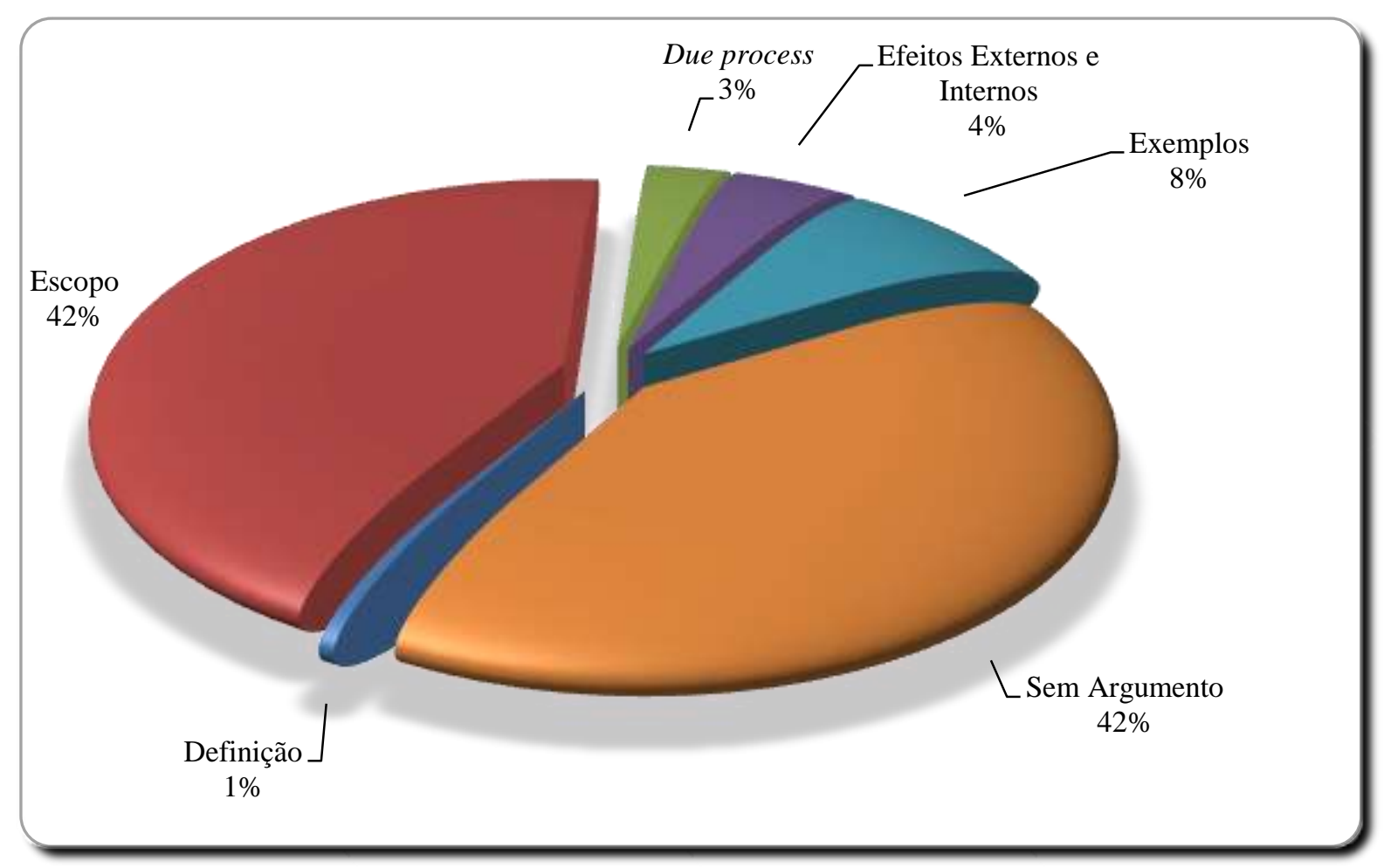

Fonte: Dados da Pesquisa

Quando comparados os achados da pesquisa com aqueles encontrados por Matos (2013) percebem-se similaridades em alguns aspectos e divergências em outros. Os argumentos classificados como Escopo também foram os mais utilizados, na maioria das respostas, atingindo $69 \%$ do total de argumentos, seguido pelos argumentos de Definição, com $15 \%$ dos argumentos dados.

Essas divergências podem ser justificadas devido à singularidade da norma de Leasing em relação à Estrutura Conceitual, tendo em vista que para aquela foi manifesta a opinião de arrendadores e arrendatários - que muitas vezes eram divergentes - e, além do mais, obteve o maior nível de discordância da pesquisa de Matos (2013). Já o elevado nível de concordância para com as questões sobre Mensuração da Estrutura Conceitual, possibilitou a utilização de dissemelhantes classificações taxonômicas. 
Quanto ao comportamento das respostas no que tange aos grupos taxonômicos em relação à opinião geral dos respondentes, a Figura 33 mostra também a similaridade em relação aos resultados do diagnóstico realizado por Matos (2013), no tocante à disparidade no comportamento dos argumentos dados.

\section{Figura 33 - Relação da Opinião Geral com a Taxonomia do Argumento - Mensuração}

A - Taxonomia das respostas concordantes

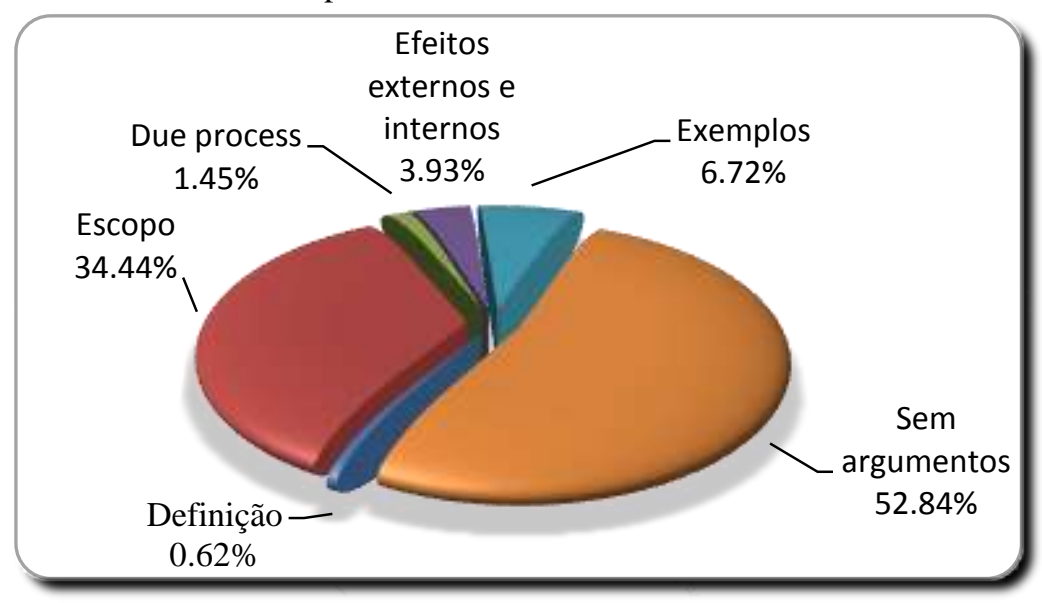

B - Taxonomia das respostas discordantes

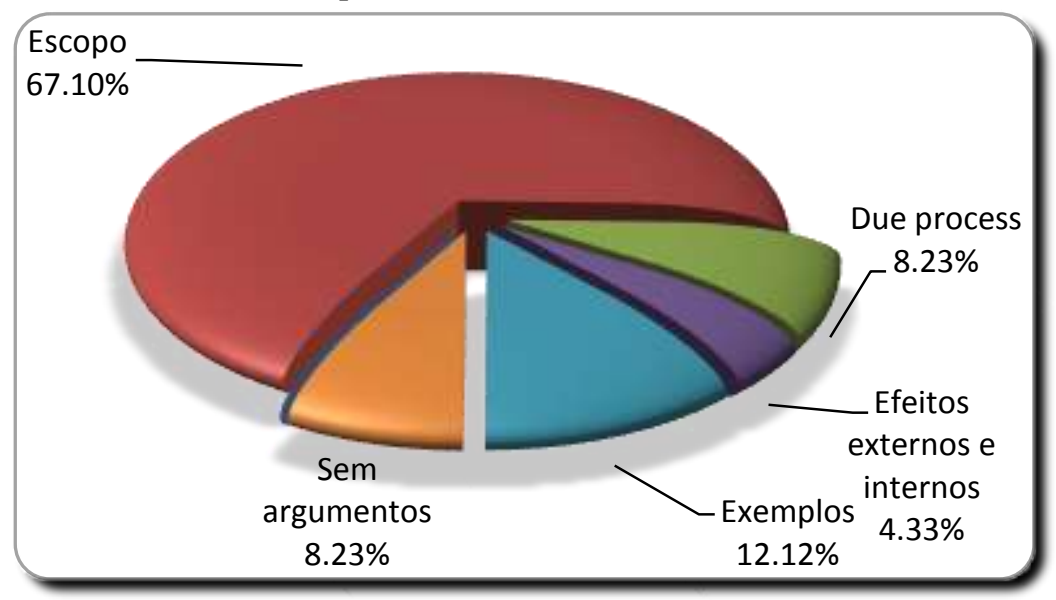

C - Taxonomia das respostas parcialmente concordantes

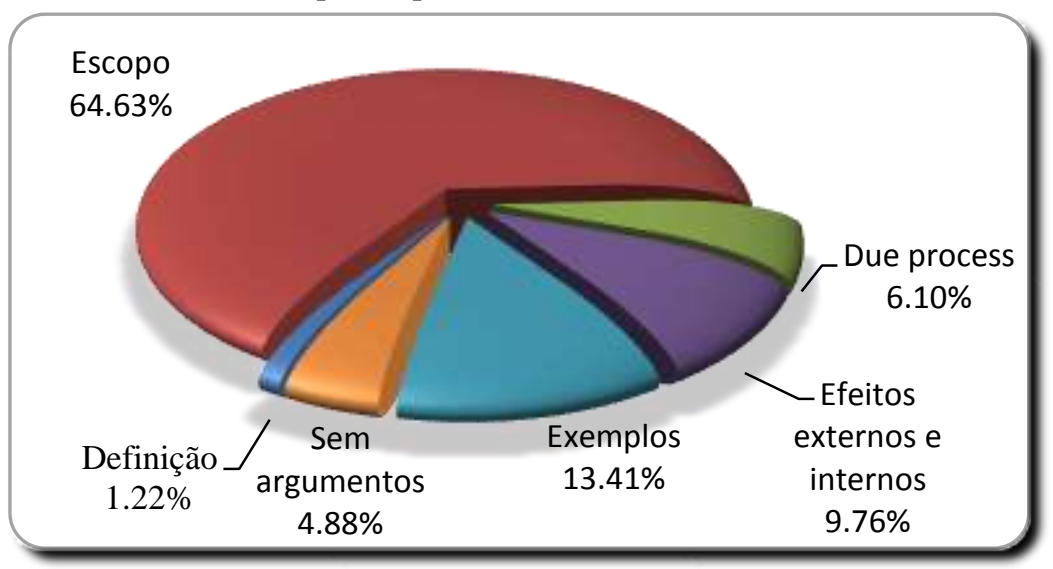

Fonte: Dados da Pesquisa 
Os achados de Matos (2013) mostraram que quando os usuários concordavam, os grupos mais relevantes foram Escopo com 73\% e Sem Argumento com 24\%, totalizando 96\% dos tipos de argumentos. Os achados desta pesquisa evidenciaram que os grupos mais expressivos foram Sem Argumento com 53\% e Escopo 34\%, totalizando 87\%.

Em relação às opiniões parciais, para Matos (2013) foram utilizados apenas argumentos classificados no grupo Escopo (100\%) e na pesquisa em questão o grupo mais utilizado foi Escopo com 65\%, seguido pelo grupo Exemplos, com 13\%, totalizando $78 \%$. Quanto às opiniões discordantes, em Matos (2013), o principal tipo de argumento também foi Escopo, com importância de 66\%, seguido dos argumentos de Definição, com $21 \%$, totalizando $87 \%$. Para essa pesquisa, a maior representatividade foi o grupo Escopo com $67 \%$ e em segundo lugar Exemplos, com 12\%, totalizando $79 \%$.

Outra divergência em relação aos resultados de Matos (2013) foi em relação à variação dos argumentos utilizados pergunta a pergunta. A Figura 34 exibe o comportamento individualizado de cada pergunta, revelando um comportamento padrão para as perguntas sobre Mensuração. Quanto a Matos (2013), o comportamento foi distinto entre as questões, mesmo a pesquisa possuindo um total de três questões e sendo este número considerado reduzido.

\section{Figura 34 - Taxonomia dos Argumentos por Pergunta - Mensuração}

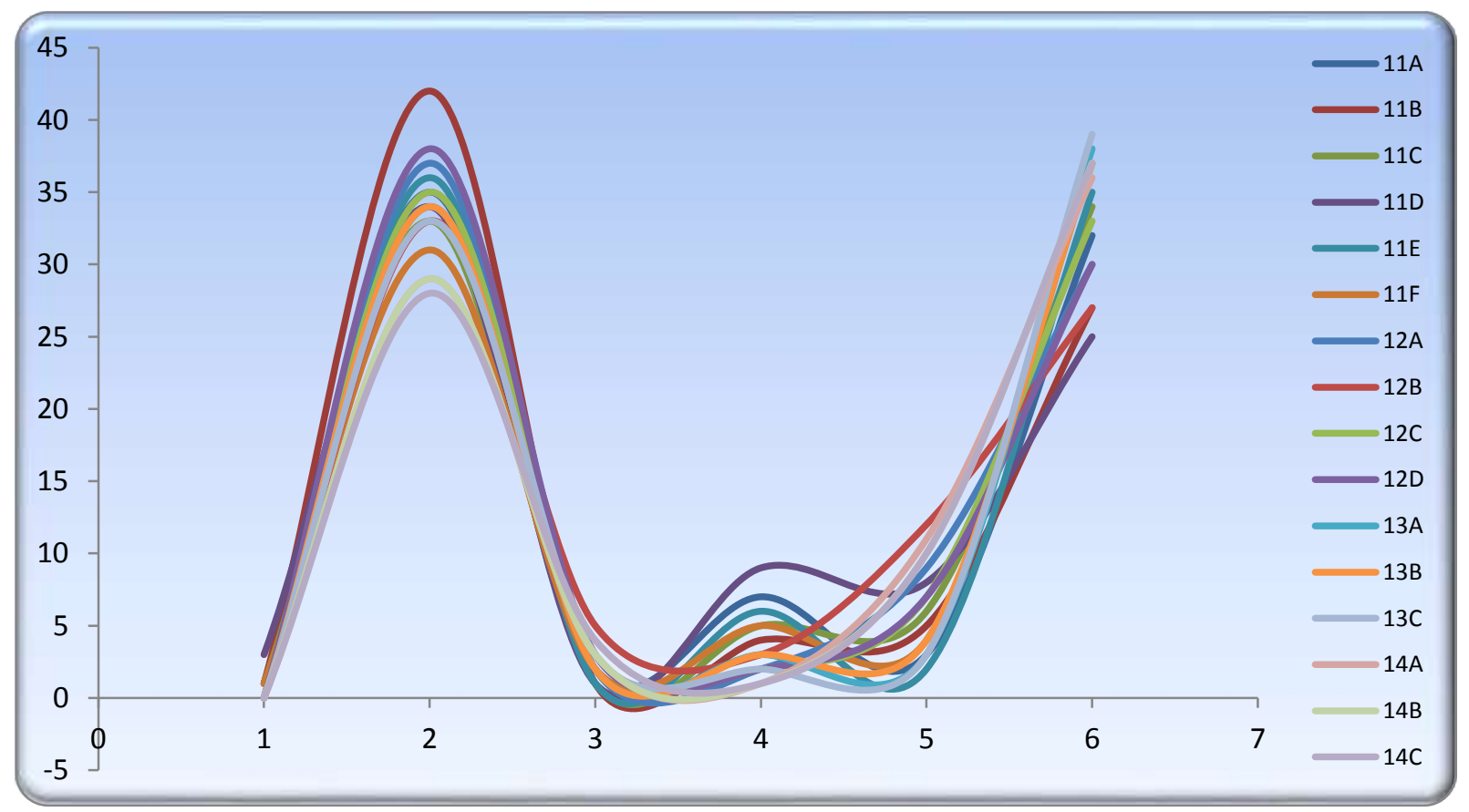

Nota: 1=Definição; 2=Escopo; 3=Due Process; 4=Efeitos Externos e Internos; 5=Exemplos; 6=Sem Argumento Fonte: Dados da Pesquisa 
As leves variações ocorridas entre as perguntas sobre Mensuração, não são consideradas suficientes para que haja distinção entre o padrão de comportamento das respostas analisadas.

\subsubsection{Apresentação e Divulgação}

No que se refere à Apresentação e Divulgação, a Figura 35 demonstra o comportamento das respostas, para as quais se segue padrão com as demais seções, tendo em vista que os argumentos de Escopo foram os mais utilizados, atingindo $43 \%$ dos argumentos totais, porém inferior à análise geral.

Em segundo lugar, figuraram as respostas sem argumento, com 24\%, seguido por Efeitos Internos e Externos (14\%) e Due process (10\%). Quanto aos argumentos Efeitos Internos e Externos e Due process, tiveram leves oscilações acima da análise geral. Já os demais grupos taxonômicos atingiram percentuais menores que a média geral.

Figura 35 - Taxonomia dos Argumentos Utilizados - Apresentação e Divulgação

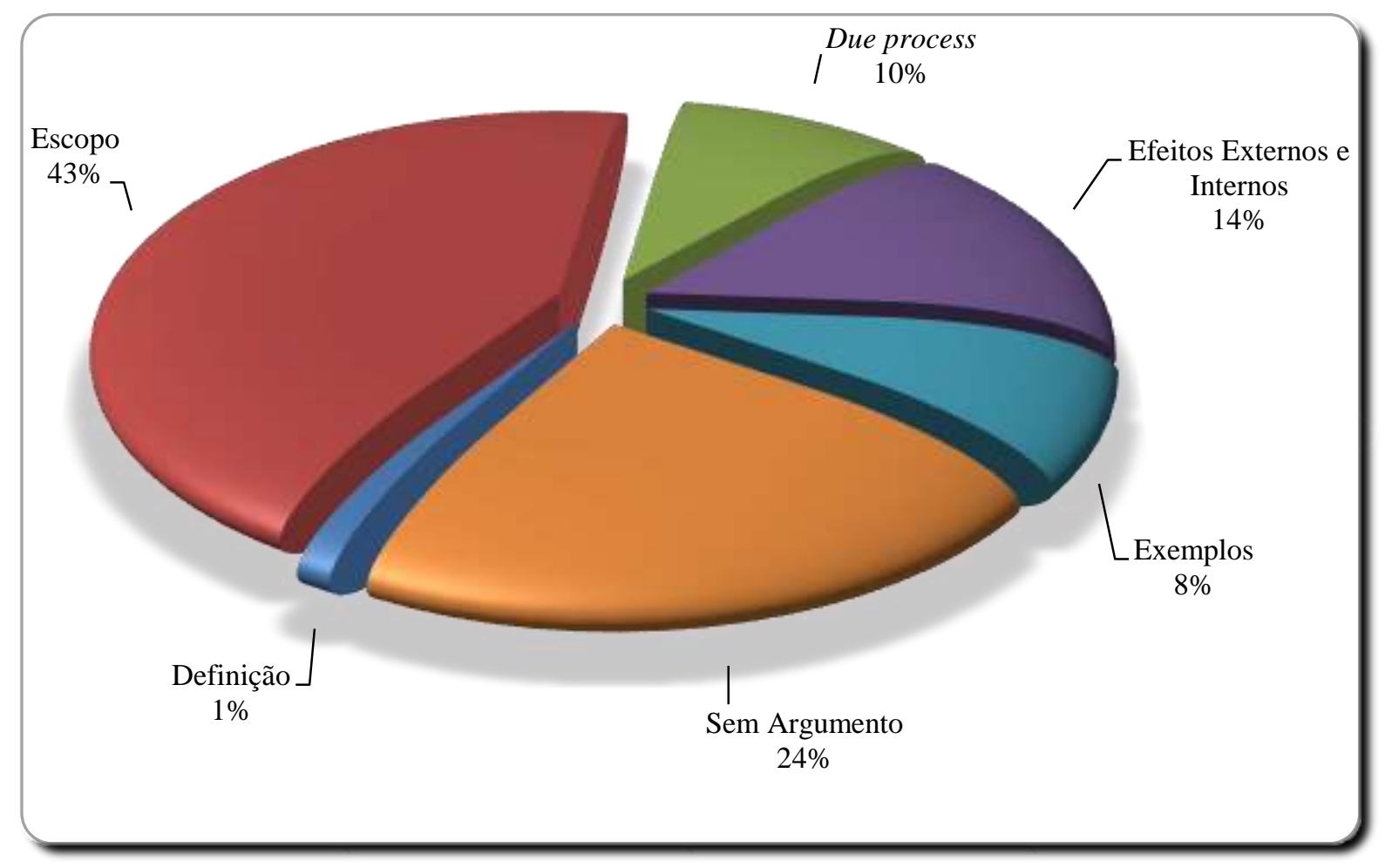

Fonte: Dados da Pesquisa 
Em comparação com a exploração de Matos (2013), os achados dessa pesquisa se diferem daqueles encontrados pelo autor, em que foi evidenciado que a maioria dos argumentos foi Efeitos Externos, totalizando 44\%, seguido por respostas Sem Argumento, com $28 \%$ e em terceiro lugar, Escopo com 18\%. Percebe-se que os argumentos de Escopo tiveram baixo percentual em comparação com essa pesquisa (Figura 35). Conforme afirmativa de Matos (2013), esse grupo se diferiu dos demais classificados naquela pesquisa.

Adicionalmente, a relação das opiniões gerais com a taxonomia dos argumentos demonstrou semelhança com a maioria das demais seções (figura 36), para as quais se pode verificar comportamento divergente entre as opiniões e taxonomias. Quanto às concordantes, foram justificadas principalmente por argumentos de escopo (40,79\%), respostas sem argumento $(33,77 \%)$ e efeitos externos e internos $(12,72 \%)$. Para respostas parciais a preferência foi argumentos de escopo (39\%), exemplos (32\%) e efeitos Externos e internos $(25 \%)$ e por fim, em caso de discordância optaram por escopo $(56 \%)$ e efeitos externos e internos (13\%).

Figura 36 - Relação da Opinião Geral com a Taxonomia do Argumento - Apresentação e Divulgação A - Taxonomia das respostas concordantes

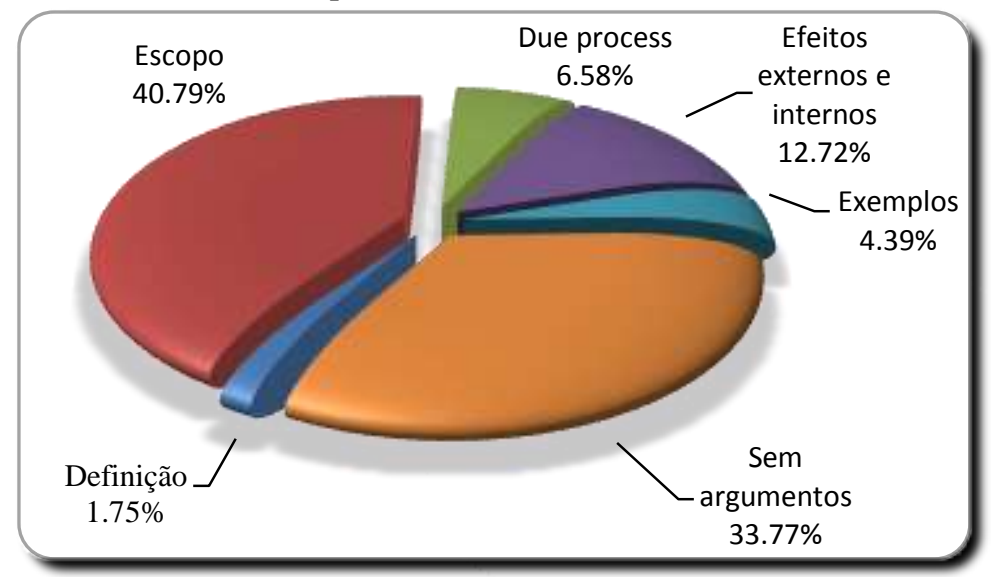

B - Taxonomia das respostas discordantes

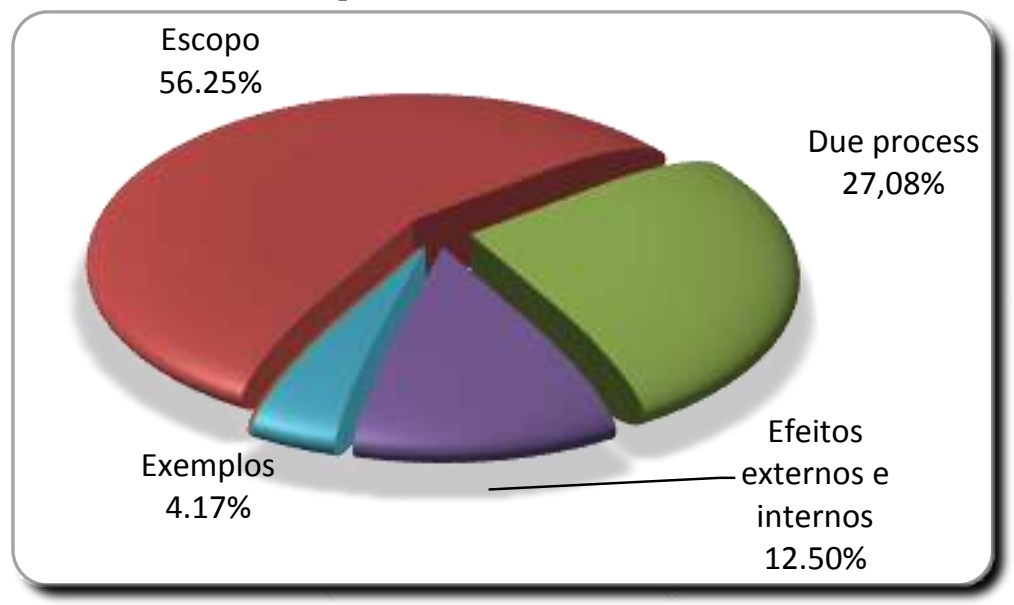


C - Taxonomia das respostas parcialmente concordantes

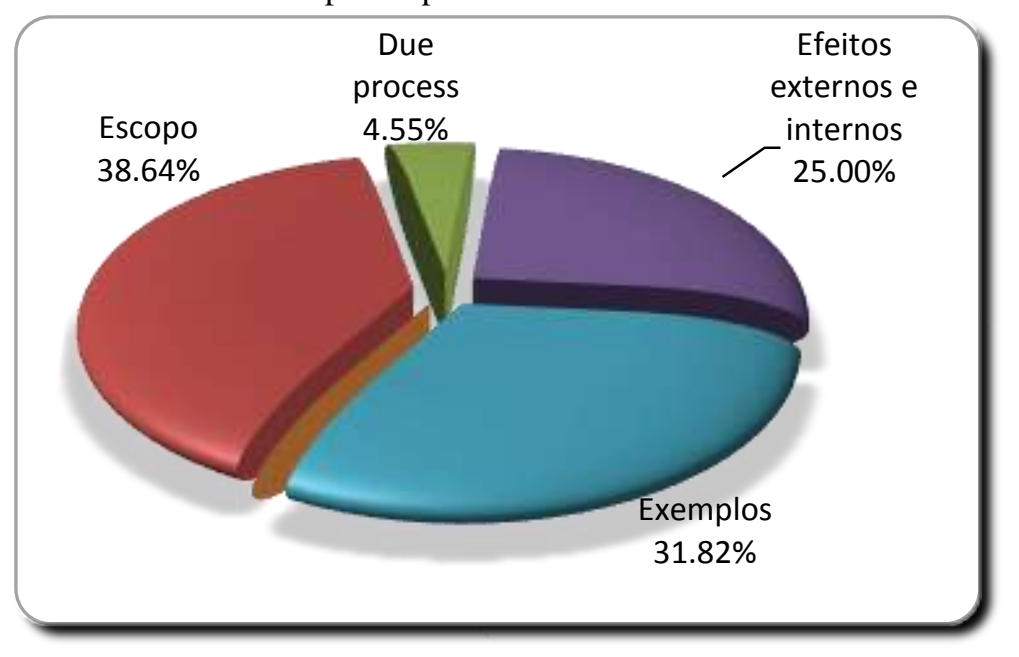

Fonte: Dados da Pesquisa

Esses resultados - no que tange à variabilidade dos argumentos dados, em relação à opinião geral, se concordante, discordante ou parcialmente concordante - foi análogo àqueles evidenciados por Matos (2013) em que as justificativas para as opiniões fornecidas, em caso de respostas positivas, eram diferentes daquelas fornecidas em respostas não concordantes.

Quando se verifica, através da Figura 37, o comportamento das opiniões pergunta a pergunta, percebe-se a não existência de padrões nas respostas dadas. Apesar de que, em principio, a maioria optou por argumentos Escopo - e esse fato é semelhante às demais -, as respostas seguiram comportamentos distintos em relação aos demais grupos de taxonomias.

As perguntas 16A (em relação à apresentação nas demonstrações financeiras primárias) e 16B (divulgações nas notas às demonstrações financeiras) tiveram maior incidência dos argumentos Due process e Efeitos Externos e Internos que as demais questões. Por sua vez as perguntas 17 (materialidade) e 18 (princípios da comunicação) tiveram maior incidência de respostas sem argumentos do que aquelas.

Em comparação com os resultados de Matos (2013) o comportamento aconteceu de forma constante para todas as perguntas analisadas, apresentando variações apenas em relação ao número de respostas para cada taxonomia. 
Figura 37 - Taxonomia dos Argumentos por Pergunta - Apresentação e Divulgação

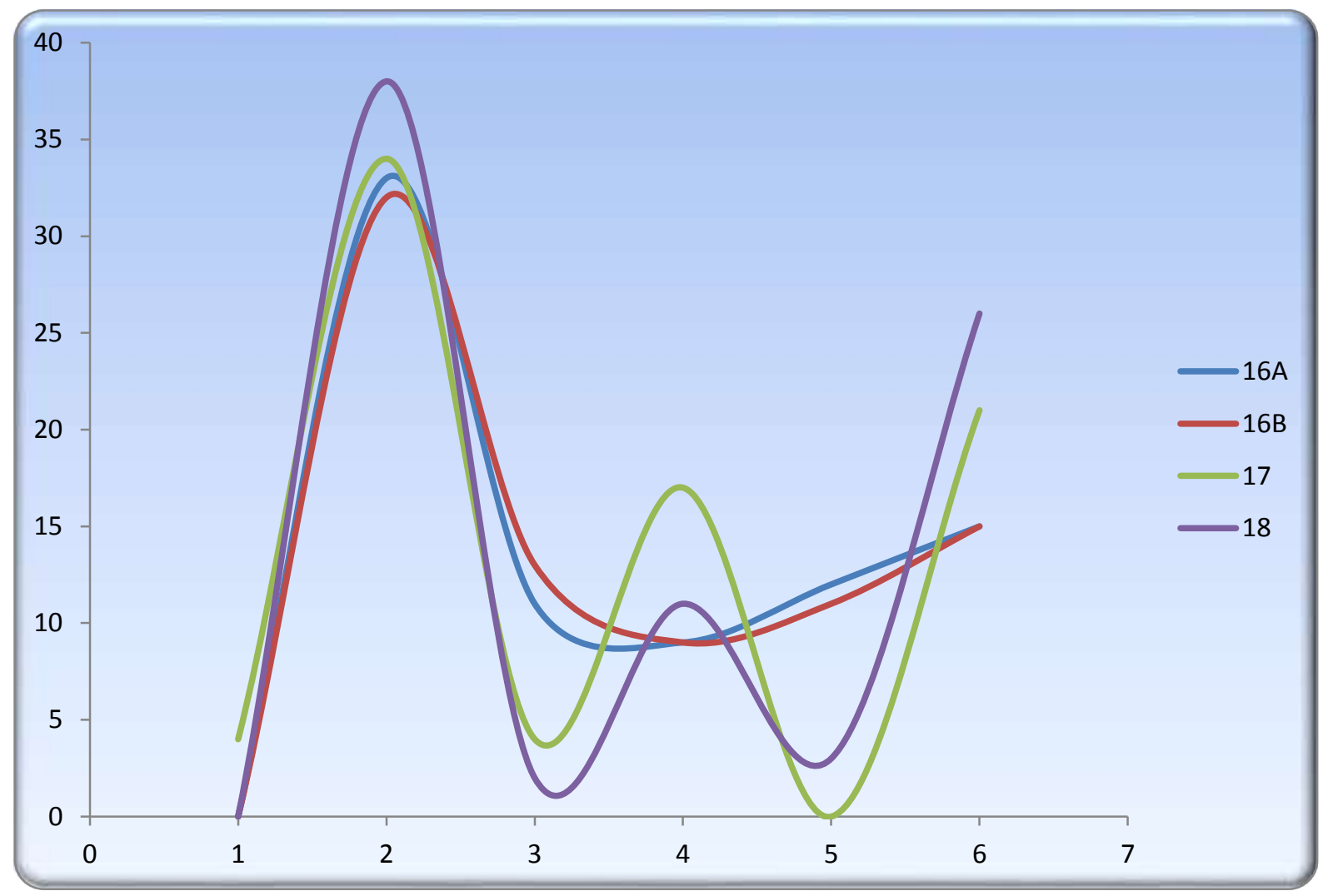

Nota: 1=Definição; 2=Escopo; 3=Due Process; 4=Efeitos Externos e Internos; 5=Exemplos; 6=Sem Argumento Fonte: Dados da Pesquisa

Complementarmente à seção Apresentação e Divulgação, fez-se necessária a análise da Apresentação na Demonstração do Resultado Abrangente - Lucros e Perdas e Outros Resultados Abrangentes no que diz respeito à exigência de um total ou subtotal para lucros e perdas, reciclagem de alguns itens de Outros Resultados Abrangentes e quanto as abordagens para Outros Resultados Abrangentes, minuciosa ou ampla.

\subsubsection{Apresentação na Demonstração do Resultado Abrangente - Lucros ou Perdas e Outros Resultados Abrangentes}

A Figura 38 mostra a supremacia dos argumentos de Escopo quanto à taxonomia dos argumentos para Apresentação na Demonstração do Resultado Abrangente - Lucros ou Perdas e Outros Resultados Abrangentes. Exceto para o grupo Escopo, a distribuição entre os demais grupos ocorreu de forma heterogênea, principalmente em relação a Efeitos Internos e Externos, Sem Argumentos e Exemplos, em que os percentuais foram próximos, sendo, 14\%, $13 \%$ e $11 \%$, respectivamente. 
Os grupos Escopo, Efeitos Externos e Internos e Exemplos foram mais utilizados nessa seção em comparação com a média geral - análise geral. Já os grupos Sem Argumentos e Due process tiveram menor participação do que a média geral.

Figura 38 - Taxonomia dos Argumentos Utilizados - Apresentação na Demonstração do Resultado Abrangente - Lucros ou Perdas e Outros Resultados Abrangentes

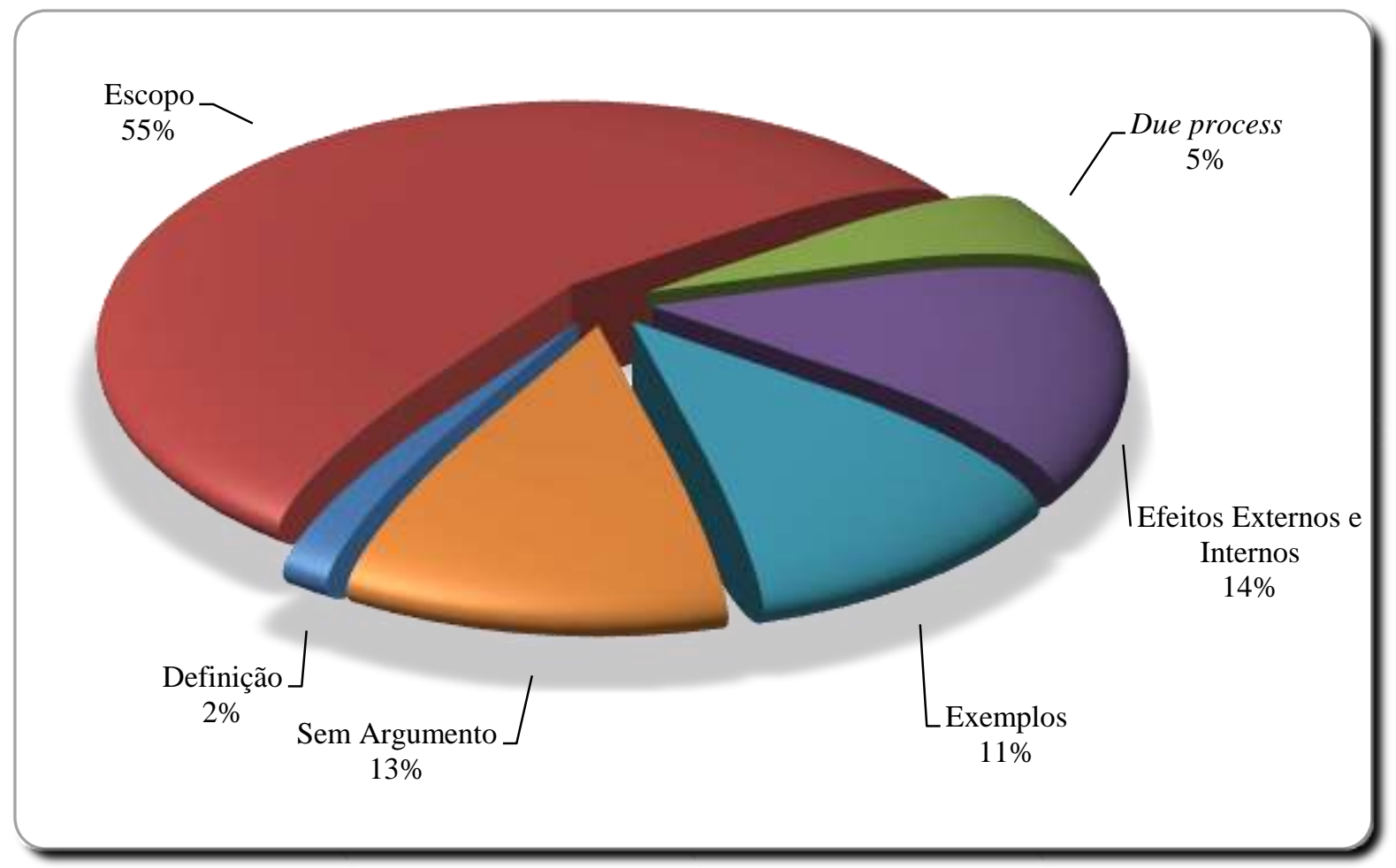

Fonte: Dados da Pesquisa

No interior da classe Escopo - classificação de argumentos mais presente para as perguntas dessa seção - $48 \%$ de sua utilização foi para justificar a concordância com as afirmativas propostas pelo IASB. Além disso, outras taxonomias bastante utilizadas nessa seção foram Efeitos Externos e internos (19\%) e Sem Argumento (16\%).

Em relação às respostas discordantes utilizaram na maioria argumentos de Escopo, com $73 \%$, seguido por argumentos de Exemplos, com 15\%, totalizando 88\%. As opiniões parciais tiveram comportamento similar, maioria Escopo, com 72\% e Exemplos (22\%), totalizando $94 \%$. 
Figura 39 - Relação da Opinião Geral com a Taxonomia do Argumento - Apresentação na Demonstração do Resultado Abrangente - Lucros ou Perdas e Outros Resultados Abrangentes

A - Taxonomia das respostas concordantes

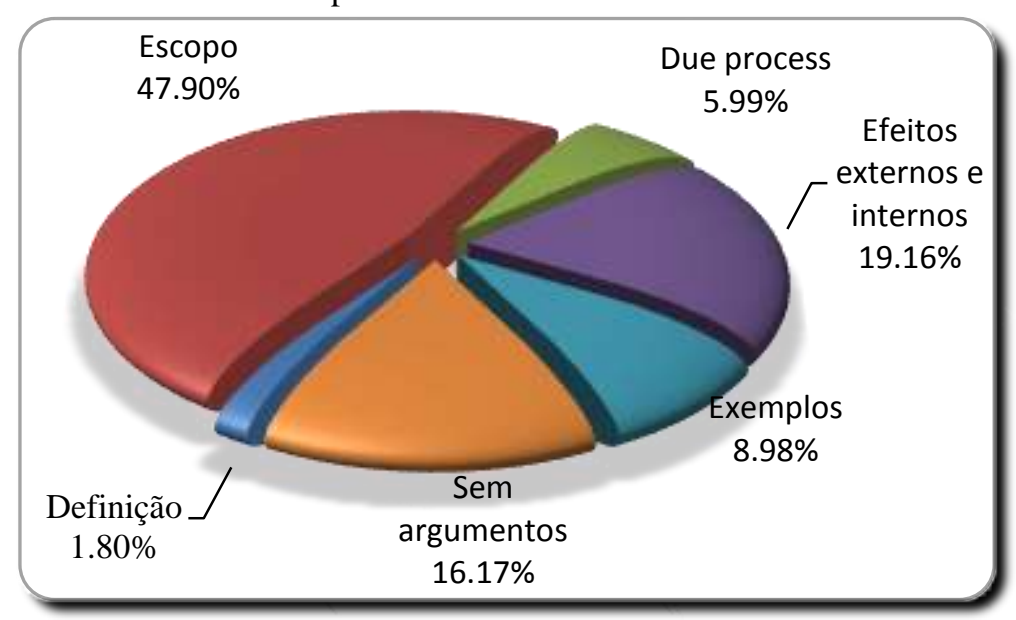

B - Taxonomia das respostas discordantes

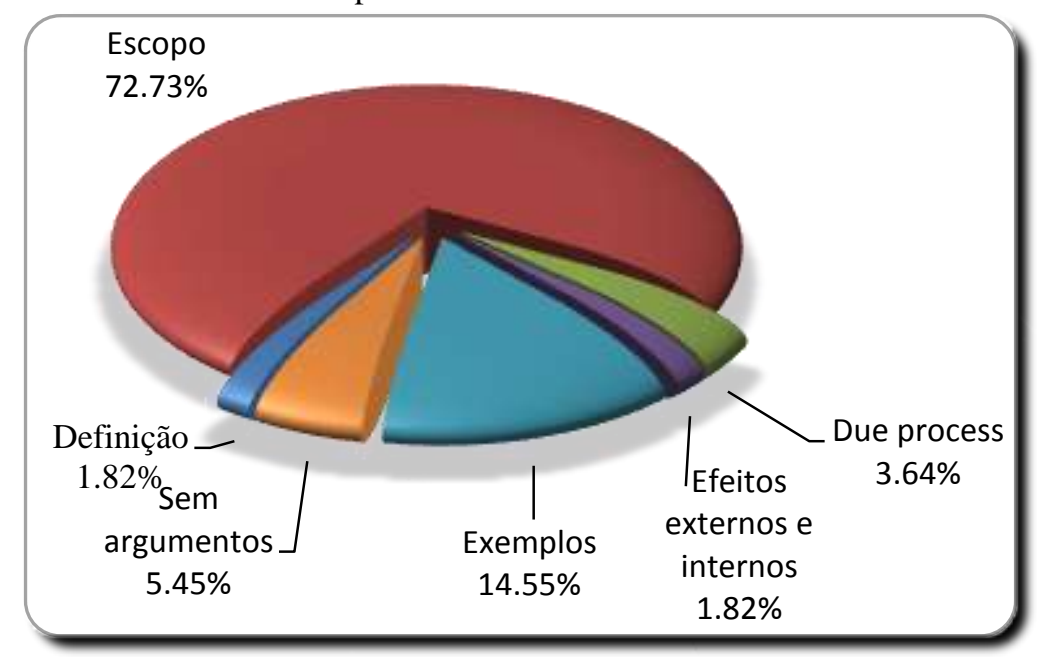

C - Taxonomia das respostas parcialmente concordantes

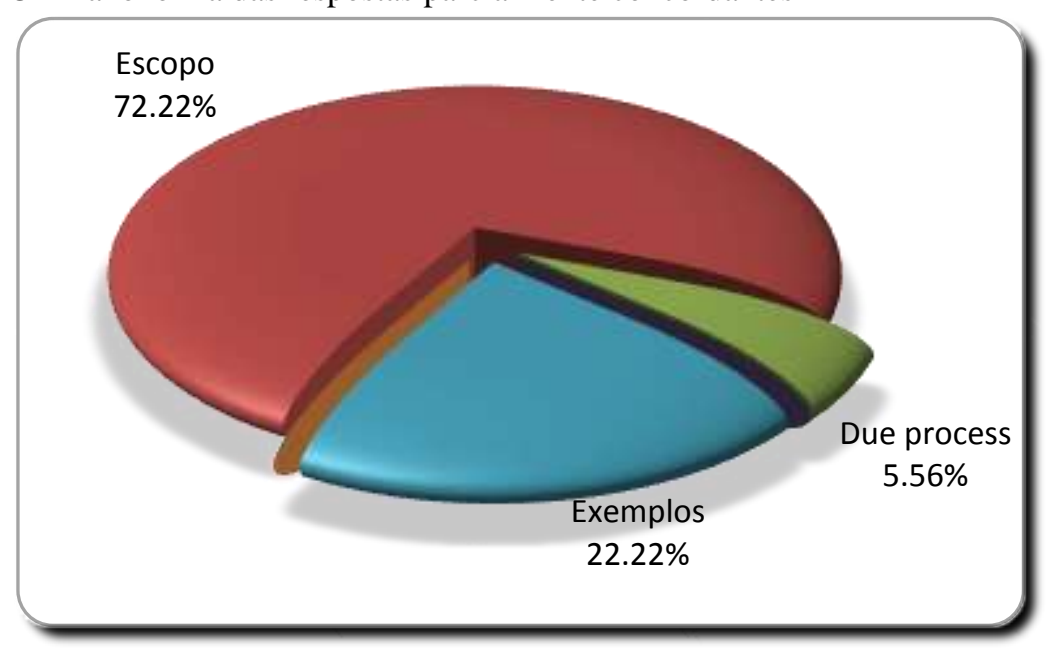

Fonte: Dados da Pesquisa 
Quando analisamos as perguntas, isoladamente, as curvas da Figura 40 mostra comportamento não padrão, devido às oscilações entre as respostas para as perguntas 19 (exigência de total ou subtotal para lucros e perdas), 20 (reciclagem) e 21 (abordagens propostas pelo IASB sobre Outros Resultados Abrangentes).

Para todas as perguntas, foram utilizados, em maioria, argumentos de Escopo divergindo apenas em quantidade de respostas. No entanto, as perguntas 19 e 20 tiveram maior ênfase, nos argumentos de Efeitos Externos e Internos e respostas Sem Argumento, do que a pergunta 21. Por sua vez, a pergunta 21 enfatizou mais argumentos de exemplos do que as demais.

Por fim, seguiu-se com a análise das demais questões não inclusas nas seções discutidas até o momento, porém de enorme relevância para a Estrutura Conceitual da Contabilidade.

Figura 40 - Taxonomia dos Argumentos por Pergunta - Apresentação na Demonstração do Resultado Abrangente - Lucros ou Perdas e Outros Resultados Abrangentes

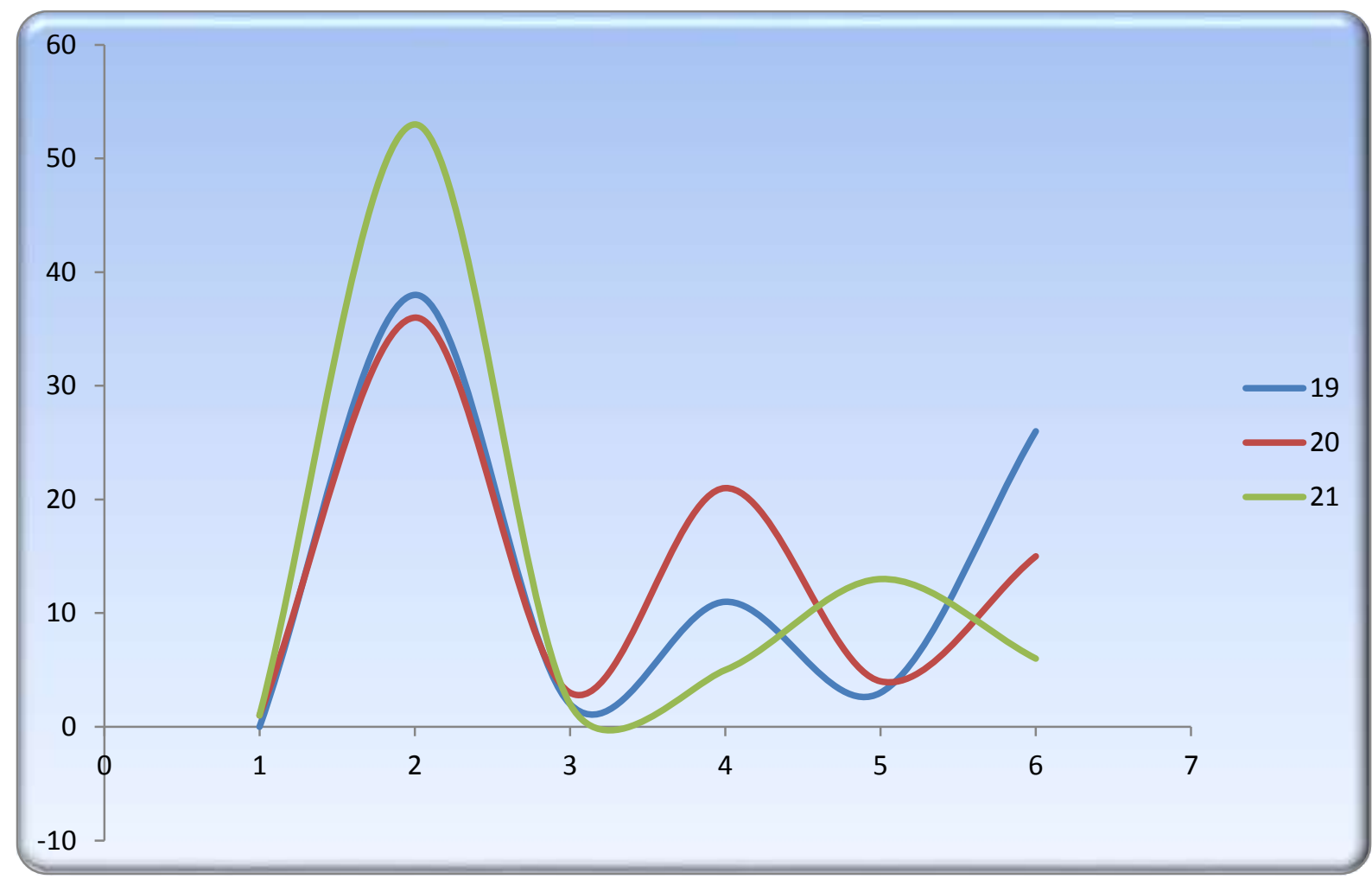

Nota: 1=Definição; 2=Scopo; 3=Duo Process; 4=Efeitos Externos e Internos; 5=Exemplos; 6=Sem Argumento Fonte: Dados da Pesquisa 


\subsubsection{Outras Questões}

As perguntas analisadas nessa seção se diferem no que diz respeito ao conteúdo tratado por cada uma. A pergunta 22 versa sobre os capítulos remanescentes da Estrutura Conceitual. A pergunta 23 discorre sobre a introdução do modelo de negócio em normas específicas. A pergunta 24 aborda Unidade de Conta e, finalmente, a 26 refere-se a Manutenção de Capital.

No que tange à taxonomia dos argumentos, segue comportamento padrão das seções anteriores, sendo que os argumentos de Escopo foram aqueles com maior ocorrência, conforme mostrado na Figura 41. Em sequência, as respostas sem justificativas figuraram em segundo lugar com 16\% do total de perguntas. Excetuando-se as taxonomias Escopo e Definição, houve distribuição de argumentos de forma heterogênea, ocorrendo apenas leves variações.

\section{Figura 41 - Taxonomia dos Argumentos Utilizados - Outras Questões}

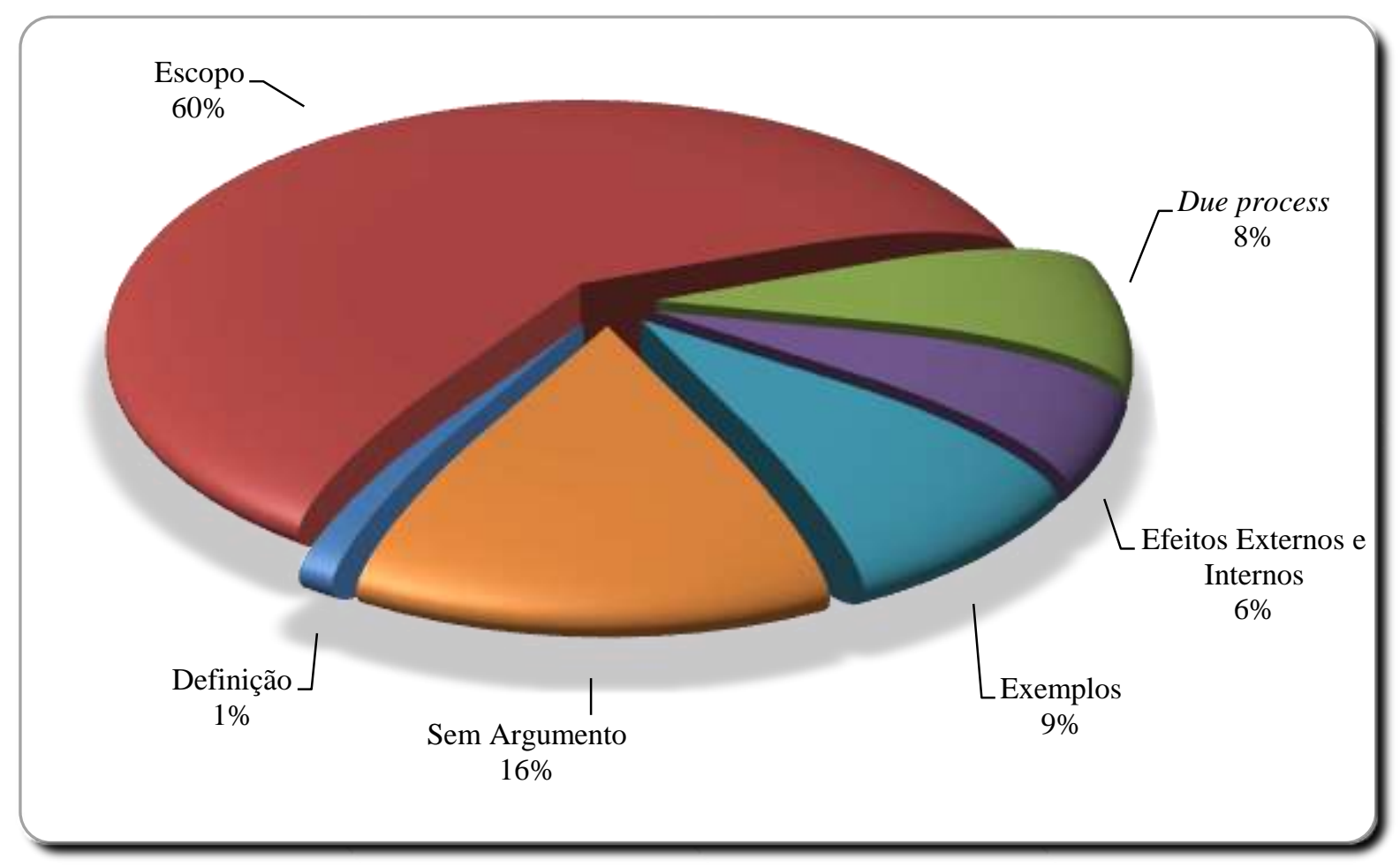

Fonte: Dados da Pesquisa

Quando se compara os resultados obtidos com a média geral obtida por intermédio das respostas gerais, percebe-se que os argumentos classificados no grupo taxonômico Escopo, Due process e Exemplos tiveram utilização superior à análise geral. Já os argumentos de 
Definição, Efeitos Externos e Internos e respostas sem argumentos foram utilizados em menor proporção que a média geral.

Quando exploramos a Figura 42, verificamos que a maioria dos tipos taxonômicos foram utilizados para justificar as resposta concordantes, o que pode ser considerado comportamento padrão. No que diz respeito às proporções, para as respostas positivas, a maioria $71 \%$ se deu através de argumento de Escopo e 9\% por argumentos Due process. Para as respostas parcialmente concordantes os argumentos de Escopo representaram $73 \%$ e Exemplos $11 \%$ e para as opiniões negativas, Escopo totalizou $71 \%$ e Exemplos $13 \%$.

O comportamento padrão de respostas para esse grupo não era esperado, tendo em vista que as quatro perguntas da seção tratavam de assuntos diversos, não interligados entre si, diferentemente de todas as seções previamente analisadas.

\section{Figura 42 - Relação da Opinião Geral com a Taxonomia do Argumento - Outras Questões}

A - Taxonomia das respostas concordantes

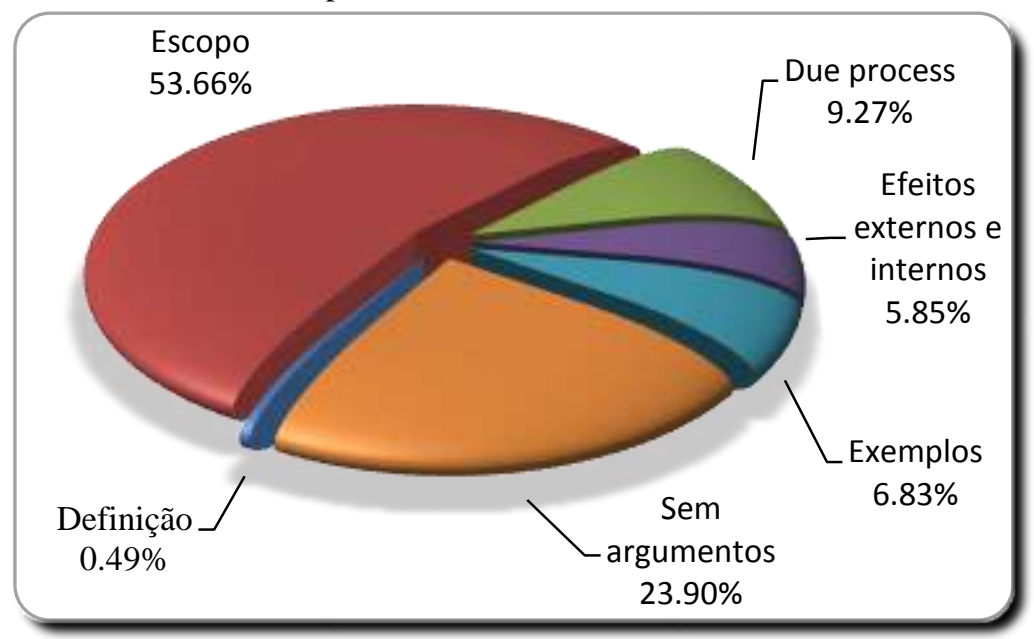

B - Taxonomia das respostas discordantes

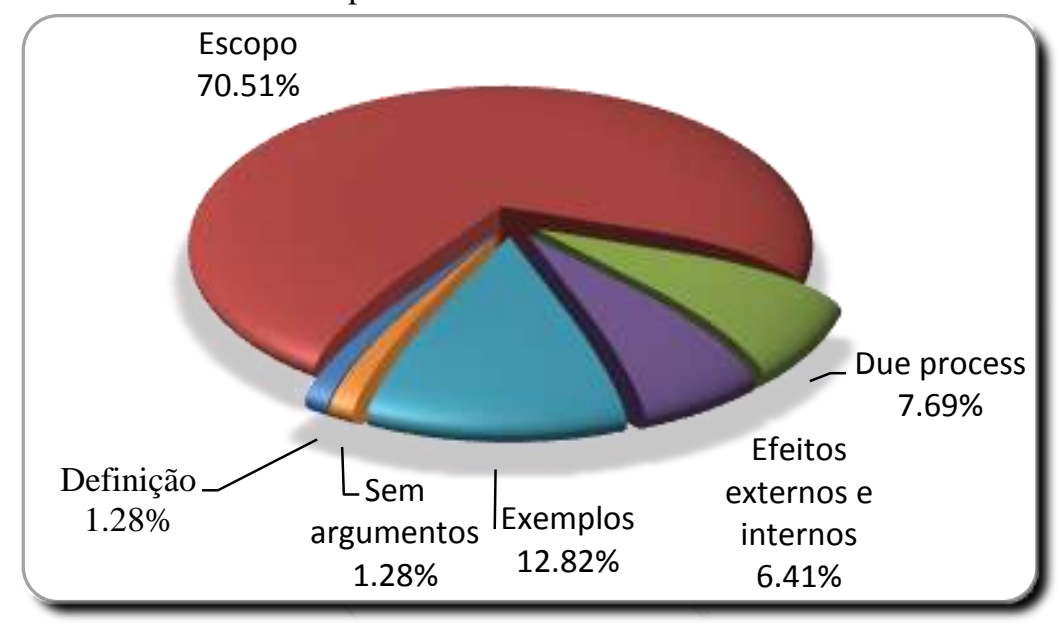


$\mathrm{C}$ - Taxonomia das respostas parcialmente concordantes

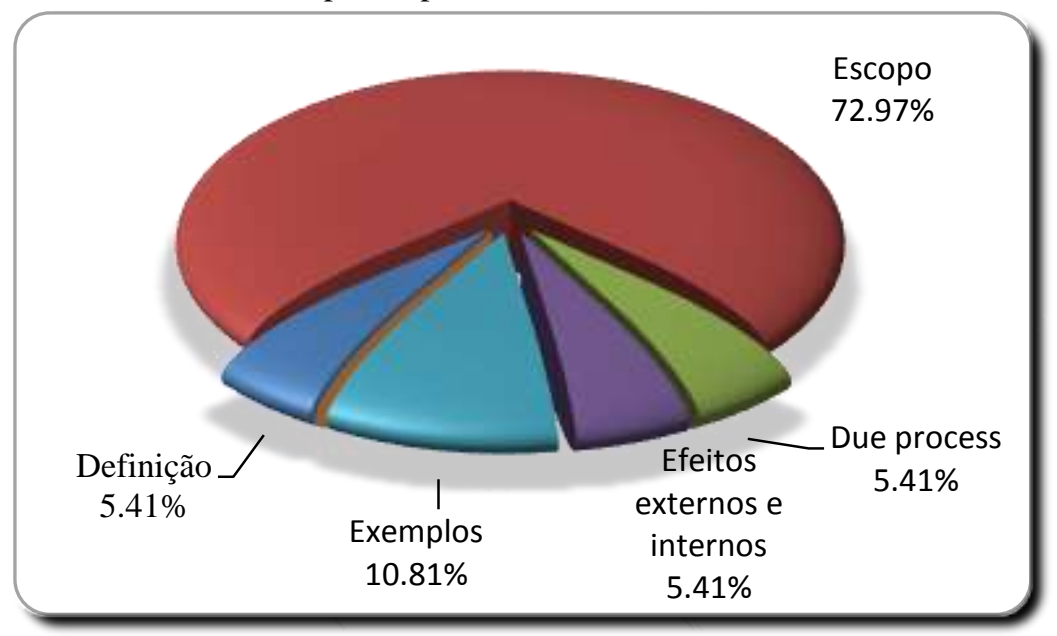

Fonte: Dados da Pesquisa

Notadamente a Figura 43 ratifica esses pressupostos, em que são analisadas as quatro questões de forma individualizada. Percebe-se que, em principio, pode-se considerar um comportamento padrão, tendo em vista que a maioria utilizou-se de proporções parecidas para os argumentos de Escopo - maior grupo de respostas para todas as questões - e, em menores proporções, para os argumentos Due process, Efeitos Externos e Internos, Exemplos e respostas sem argumentos.

\section{Figura 43 - Taxonomia dos Argumentos por Pergunta - Outras Questões}

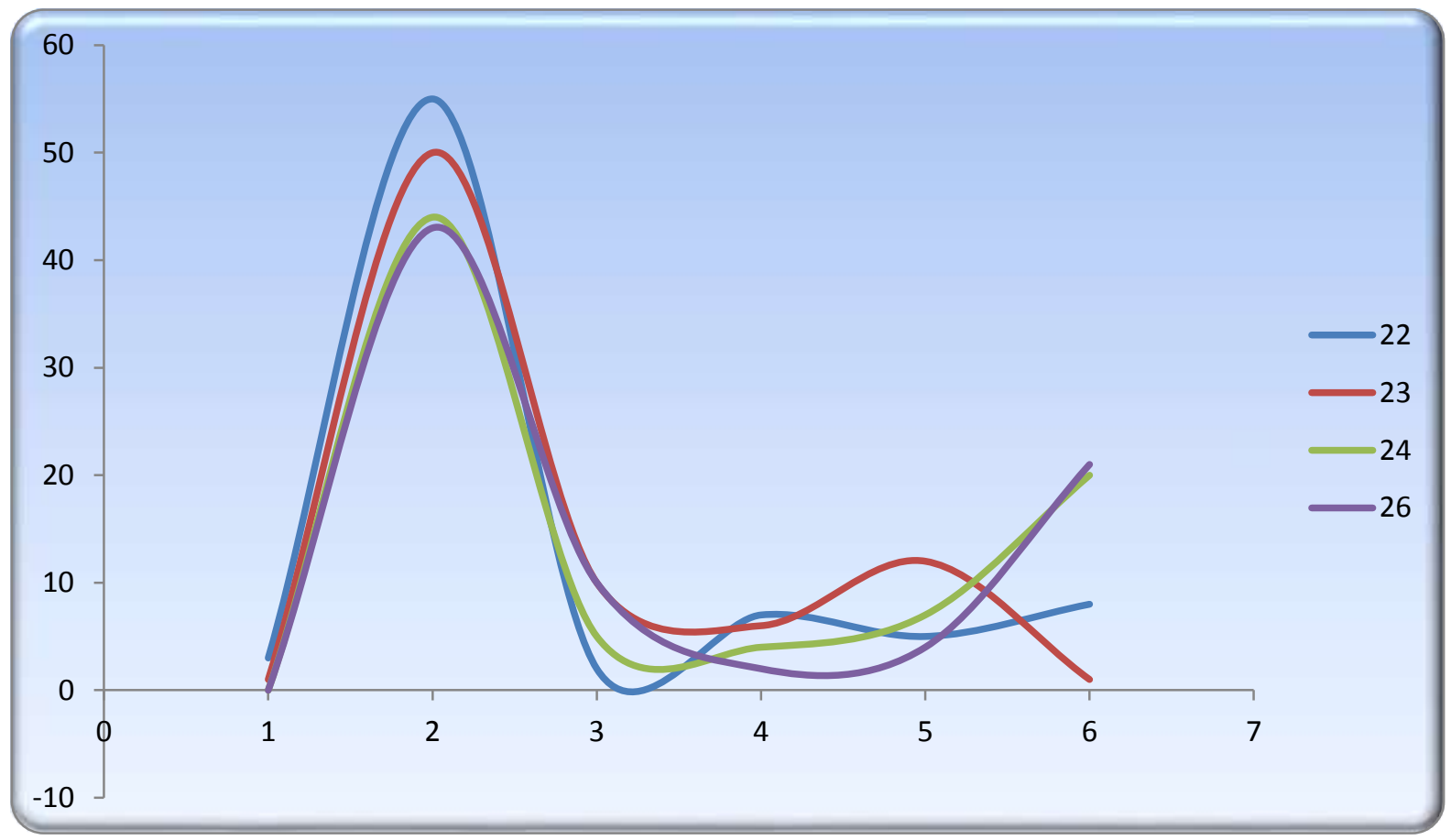

Nota: 1=Definição; 2=Escopo; 3=Due Process; 4=Efeitos Externos e Internos; 5=Exemplos; 6=Sem Argumento Fonte: Dados da Pesquisa 


\subsubsection{Visão Geral}

Dessa maneira, a análise da taxonomia dos argumentos revelou que o comportamento dos respondentes, no que tange às justificativas para as perguntas do DP/2013/1, variou de acordo com as seções examinadas: 1) introdução; 2) elementos das demonstrações financeiras; 3) orientações adicionais de apoio às definições de ativos e passivos; 4) reconhecimento e desreconhecimento; 5) definição de capital próprio e distinção entre passivos e instrumento de patrimônio; 6) mensuração; 7) apresentação e divulgação; 8) apresentação na demonstração de resultados abrangentes e 9) outras questões.

Esse fato se justifica devido a diversidades das questões tratadas pelo DP/2013/1 e pela abrangência da Estrutura Conceitual, sendo alicerce para o IASB, Normatizadores, Preparadores e demais usuários no que diz respeito à criação, alteração e aplicação das Normas - IRFS.

As hipóteses no que se refere a taxonomias dos argumentos eram:

$\mathrm{H}_{0}: \mu<0,5$ - A média dos argumentos não teóricos (escopo) utilizados para fundamentar as respostas dos respondentes no tocante as perguntas do DP/2013/1 é menor que $50 \%$, isto é, a maioria dos respondentes utiliza argumentos teóricos, baseados em normas ou definições, para fundamentar suas opiniões no tocante a proposta de mudança da Estrutura Conceitual.

$\mathrm{H}_{1}: \mu \geq 0,5$ - A média dos argumentos não teóricos (escopo) utilizados para fundamentar as respostas dos respondentes no tocante as perguntas do DP/2013/1 é maior ou igual a 50\%, isto é, a maioria dos respondentes utiliza argumentos não teóricos, baseados na experiência pratica ou no que pensam para fundamentar suas opiniões no tocante a proposta de mudança da Estrutura Conceitual.

Foi possível rejeitar $\mathrm{H}_{0}$ em favor de $\mathrm{H}_{1}$ tendo em vista que os resultados apontaram notadamente a utilização dos argumentos de Escopo em detrimento dos demais, para todas as seções analisadas - em maiores ou menores proporções que a análise geral - levando-nos a inferência de que os respondentes possuíam conhecimento prévio, inclusive esboçando argumentos sólidos para prática contábil e encorajando o IASB em relação às mudanças propostas.

A medida que os respondentes concordavam, optavam por justificar suas respostas por argumentos classificados como escopo e respostas sem argumentos, atingindo os percentuais de $44,45 \%$ e $36,97 \%$, respectivamente das respostas para as quais os respondentes afirmavam que concordavam. Quando discordavam, os respondentes optavam principalmente por 
argumentos classificados como escopo e exemplos, atingindo $61,43 \%$ e $12,18 \%$ respectivamente.

Suplementarmente, as respostas sem argumento ocorreram com maior ênfase quando os respondentes concordavam com a questão proposta, pois, é possível que na visão dos respondentes, à medida que concordo, "sinto-me desobrigado a argumentar". Esse fato é justificado, porque os respondentes, na maioria das vezes em que discordavam - total ou parcialmente -, procuravam indicar o motivo para a discordância. Os demais argumentos foram utilizados em proporções convergentes, em relação ao tipo de taxonomia. 


\section{CONSIDERAÇÕES FINAIS}

A presente pesquisa teve como objetivo geral analisar a percepção dos usuários da contabilidade sobre a proposta de revisão da Conceptual Framework for Financial Reporting propostos no Discussion Paper - DP/2013/1 emitido pelo International Accounting Standard Board - IASB. Para isso, apoiou-se nas perspectivas de que as opiniões dos respondentes poderiam auxiliar o referido órgão, no que tange a elaboração de um referencial conceitual que fornecesse suporte a normas alinhadas com as necessidades dos diversos usuários da informação financeira.

As principais justificativas para a pesquisa foram:

a) A Estrutura Conceitual do IASB é um documento que auxilia o IASB na elaboração de futuras IFRSs e na revisão de normas existentes, pois consiste em um conjunto de conceitos e orientações que embasam as decisões do referido órgão na operacionalização de seu trabalho, na promoção da convergência;

b) Auxilia os normatizadores nacionais a elaborar suas normas, mitigando a assimetria da informação e produzindo um referencial que dá suporte ao reconhecimento, mensuração e evidenciação dos elementos das demonstrações financeiras, baseadas nas características qualitativas da informação contábil;

c) Auxilia os usuários da contabilidade a interpretar as informações evidenciadas nos relatórios financeiros, tendo em vista que ela fornece um arcabouço teórico, incluindo conceitos e orientações de finalidade geral que possibilita o entendimento dos principais elementos da informação financeira no tange ao reconhecimento, mensuração e disclosure;

d) Possibilita a promoção e a sustentação das diferenças significativas no comportamento social, passando a considerar os aspectos culturais e, além disso, deixando de tratar a contabilidade financeira como uma atividade técnica, sem valor;

e) De forma indireta, possibilita a economias de escala; a proteção que dão auditores contra os gestores que desempenham um jogo "opinion shopping"; facilita a comunicação, eliminam externalidades informacionais decorrentes da falta de comparabilidade, contribui para a redução das diferenças nos relatórios financeiros, implicando em convergência das normas contábeis;

f) Auxilia os preparadores, fornecendo um referencial conceitual - conceitos e orientações gerais - que dão suporte à elaboração de relatórios financeiros, de 
propósito geral, em nível internacional, que serão uteis aos diversos usuários da informação financeira;

g) A proposta do DP/2013/1 permite que os diversos agentes (de diversos países), interessados na elaboração de Relatórios Financeiros - Preparadores, Normatizadores, Academia, Reguladores e outros - possam participar da elaboração da alteração da Estrutura Conceitual, através das suas opiniões no tocante aos diversos elementos elencados na proposta da Estrutura Conceitual.

Em linhas gerais a Estrutura Conceitual é um documento que auxilia o IASB e outros agentes, tais como: Preparadores, Normatizadores, Academia, Reguladores na promoção da convergência das políticas e práticas contábeis em nível internacional.

Com o intuito de alcançar o objetivo principal da pesquisa, foram sistematizados três objetivos específicos.

O primeiro objetivo específico era identificar o nível de concordância ou discordância dos usuários da informação contábil, em face da proposta de revisão da Conceptual Framework for Financial Reporting.

Esse objetivo foi alcançado à medida que foi executada uma análise geral, considerando a totalidade das 44 perguntas analisadas, de forma detalhada. O nível de concordância geral atingido foi um percentual de 69,72 das respostas analisadas, seguido por 20,91 e 9,38 pontos percentuais, respectivamente para o nível de discordância e opiniões parciais - aqueles que concordavam em alguns aspectos e discordavam em outros. A avaliação pormenorizada, seção por seção: 1) introdução; 2) elementos das demonstrações financeiras; 3) orientações adicionais de apoio às definições de ativo e passivos; 4) reconhecimento e desreconhecimento; 5) definição de capital próprio e distinção entre passivos e instrumento de patrimônio; 6) mensuração; 7) apresentação e divulgação; 8) apresentação na demonstração de resultados abrangentes e 9) outras questões, evidenciou o nível de concordância para cada uma, mostrando que o maior nível de aceitação ocorreu na seção 3, atingindo o percentual de 84,38. Já o maior nível de rejeição ocorreu na seção 5, alcançando o percentual de 36,88 .

No que diz respeito ao maior nível de aceitação, seção 3 - orientação adicional de apoio às definições de Ativo e Passivo, a maioria dos respondentes pensam que a manutenção das definições existentes, principalmente Passivo englobando obrigações legais e construtivas podem produzir melhor qualidade da informação contábil evidenciada através dos relatórios financeiros. Na visão dos respondentes a mudança poderia resultar em algumas dificuldades 
na classificação de certos instrumentos como Passivo ou Patrimônio Líquido e que a proposta do IASB para esses elementos seria a melhor alternativa possível.

No tocante ao maior discordância, seção 5 - definição de PL e distinção de Passivo e Instrumento de Capital, os agentes - em maioria - discordaram das alternativas C e D, afirmando que havia a necessidade de esclarecimentos adicionais acerca da proposta e que não estavam convencidos de que aquelas seriam as melhores alternativas para que os elementos em questões. Alguns usuários afirmaram a necessidade de esclarecimentos adicionais acerca da proposta. Ressalta-se que para esses elementos o IASB ainda não chegou a uma decisão definitiva, mesmo após a reunião realizada em 24 de abril de 2014 e assim sendo, o assunto voltará a debate em reuniões do IASB para decisões mais concretas.

Com base nas hipóteses da pesquisa,

$\mathrm{H}_{0}: \mu<0,5$ - A média de concordância dos respondentes das perguntas do DP/2013/1 é menor que $50 \%$, isto é, a maioria dos respondentes discorda da proposta do IASB, no tocante a proposta de mudança da Estrutura Conceitual.

$\mathrm{H}_{1}: \mu \geq 0,5$ - A média de concordância dos respondentes das perguntas do DP/2013/1 é maior ou igual a 50\%, isto é, a maioria dos respondentes concorda com a proposta do IASB, no tocante a proposta de mudança da Estrutura Conceitual.

Foi possível rejeitar $\mathrm{H}_{0}$ em favor de $\mathrm{H}_{1}$, em que as interpretações dos resultados indicam que a maioria dos respondentes concorda com proposta do IASB no que diz respeito a mudanças propostas no DP/2013/1.

O segundo objetivo específico era identificar, classificar e avaliar as opiniões apresentadas pelos usuários acerca da revisão da Conceptual Framework for Financial Reporting do IASB, proposta no Discussion Paper 2013/1 e o terceiro objetivo especifico era identificar e avaliar as taxonomias dos argumentos utilizados para a fundamentação das percepções dos respondentes, á luz dos argumentos da Teoria da Contabilidade.

Esses objetivos foram alcançados à medida que foram analisadas as respostas dos respondentes, classificando-as por tipo de argumento, com o propósito de compreender de que forma os respondentes embasaram suas respostas - concordantes, discordantes e parciais acerca do DP/2013/1. As categorias definidas para classificação foram: Escopo, Definição, Due Process, Efeitos Externos e Internos, Exemplos e Sem Argumento. O tipo de argumento mais utilizado - de acordo com a classificação da pesquisa - foi o da categoria Escopo, utilizado em $49 \%$ do total de perguntas.

A maioria dos usuários tenta prever as implicações práticas que as mudanças propostas pelo IASB através do DP/2013/1 acarretarão para a contabilidade e, por conseguinte para os 
agentes envolvidos nesse processo. Eles procuram evidenciar os impactos causados principalmente na qualidade da informação fornecida nos relatórios financeiros de proposito geral.

Em linhas gerais, esse comportamento mostrou que grande parte dos respondentes fazem uso da experiência prática e o que pensam acerca de determinados assuntos, procurando inferir suas possíveis consequências, evidenciando sua robustez e debilidades, sem a utilização de qualquer embasamento teórico que desse suporte a temática analisada.

Suplementarmente, as respostas sem argumento ocorreram com maior ênfase quando os respondentes concordavam com a questão proposta, pois, é possível que na visão dos respondentes, à medida que concorda, "sente-se desobrigado a argumentar".

Com base nas hipóteses da pesquisa,

$\mathrm{H}_{0}: \mu<0,5$ - A média dos argumentos não teóricos (escopo) utilizados para fundamentar as respostas dos respondentes no tocante as perguntas do DP/2013/1 é menor que $50 \%$, isto é, a maioria dos respondentes utiliza argumentos teóricos, baseados em normas ou definições, para fundamentar suas opiniões no tocante a proposta de mudança da Estrutura Conceitual.

$\mathrm{H}_{1}: \mu \geq 0,5$ - A média dos argumentos não teóricos (escopo) utilizados para fundamentar as respostas dos respondentes no tocante as perguntas do DP/2013/1 é maior ou igual a 50\%, isto é, a maioria dos respondentes utiliza argumentos não teóricos, baseados na experiência pratica ou no que pensam para fundamentar suas opiniões no tocante a proposta de mudança da Estrutura Conceitual.

Foi possível rejeitar $\mathrm{H}_{0}$ em favor de $\mathrm{H}_{1}$, em que as interpretações dos resultados evidenciam que a maioria dos argumentos utilizados pelos respondentes são classificados na categoria escopo (não teóricos) baseados na experiência prática dos respondentes ou no que pensam em relação ao item do DP/2013/1 para o qual esboçavam suas opiniões.

O processo normativo do IASB é composto por 6 etapas que se seguem. Dessa forma, a revisão da Estrutura Conceitual teve seu projeto recomeçado em 2012, e o IASB pretende completar as revisões até o final de 2015. Por esse motivo, o Discussion Paper 2013/1 será considerado como a versão final do documento para análise dos resultados, assinalando assim uma limitação desta pesquisa. Esse fato parte dos seguintes axiomas: a) acredita-se que as diferenças emanadas da relação DP/2013/1 versus versão final, não serão significativas para a pesquisa; b) em razão da data limite permitida para apresentação desta pesquisa, não é possível aguardar a versão final da Estrutura Conceitual, e c) o principal objetivo desta 
pesquisa pode ser alcançado através da análise do Discussion Paper e das Comment Letters referentes a ele, sem acometer os resultados.

Por fim são sugeridas novas pesquisas no âmbito da Conceptual Framework for Financial Reporting, tendo em vista um tema oportuno e pertinente:

a) Evidenciar as implicações dos comentários proferidos pelos respondentes das comment letters do DP/2013/1 e Exposure draft no que tange sua aceitação pelo IASB no desenvolvimento da versão final da Estrutura Conceitual.

b) Analisar os conceitos elencados na versão final da Estrutura Conceitual à luz da teoria contábil, evidenciando qual a opinião dos principais autores da teoria da contabilidade, com base em suas publicações: dissertações, teses, papers e livros.

c) Mostrar as implicações dos fatores culturais, ambiente legal, sistema contábil e contexto educacional para a Conceptual Framework for Financial Reporting. 


\section{REFERÊNCIAS}

ASHBAUGH, H., \& PINCUS, M. Domestic accounting standards, international accounting standards and the predictability of earnings. Journal of Accounting Research, 39, p. 417-434, 2001.

ASKARY, Saeed. Accounting professionalism - a cultural perspective of developing countries. Managerial Auditing Journal, v. 21, n. 1, pp. 102-111, 2006.

BALL, Ray. International Financial Reporting Standards (IFRS): Pros and Cons for Investors. Accounting and Business Research, Forthcoming, 2005. Available at SSRN: http://ssrn.com/abstract=929561.

. Making accounting more international: Why, how, and how far will it go? Journal of Applied Corporate Finance, 8, Fall, 1995, p. 19-29.

BARDIN, Laurence. Análise de conteúdo. Tradução Luís Antero Reto, Augusto Pinheiro. São Paulo: Edições 70, 2011, 279p.

BARTH, M.E.; LANDSMAN, W.R.; LANG, M.H. International Accounting Standards and accounting quality. Journal of Accounting Research, v. 46, n. 3, p. 467-498, Jun, 2008.

BELKAOUI, Ahmed Riahi. Accounting Theory. 5. ed. London: Thomson Learning, 2004. 598p.

BENCE, David John. The Conceptual Framework for Financial Reporting in The U. K. The Objectives and Opinions of the Participants in the Financial Reporting Process. These (Doutorado em Ciências Contábeis). Bristol Business School, University of the West of England, Bristol, October, 1996.

BRADBURY, Michel E. Implications for the Conceptual Framework Arising From Accounting for Financial Instruments. ABACUS, v. 39, n. 3, 2003.

CHEN, H.; TANG, Q.; JIANG, Y.; LIN, Z. The role of accounting standards: evidence from the European Union. Journal of International Financial Management \& Accounting, v. 21, n. 3, p. 1-57, 2010.

CHOI, Frederick D. S.; MEEK, Gary K. International Accounting. 7 ed. Prentice Hall. 2011, 476p.

CHRISTENSEN, H.B.; LEE, E.; WALKER, M. Cross-sectional variation in the economic consequences of international accounting harmonization: the case of mandatory IFRS adoption in the UK. The International Journal of Accounting, v. 42, p. 341-379, 2007.

COCHRAN, Willian G. Sampling techniques. 3th ed. New York: John Wiley e Sons, 1977. 
CUIJPERS, R.; BUIJINK, W; MAIJOOR, Steven. Voluntary Adoption of Non-local GAAP in the European Union: A Study of Determinants and Consequences. European Accounting Review, v. 14, n. 3, pp. 487-524, 2002.

DENNIS, Ian David. A Philosophical Investigation into the Conceptual Framework for Accounting. Tese PhD, London School of Economics, University of London, (s/d).

DOPUCH, Nicholas; SUNDER, Shyam. FASB's Statements on Objectives and Elements of Financial Accounting: A Review, Accounting Review, v. 55, n. 1: 1-21, 1980 apud ZEFF, Stephen A. The Evolution of the Conceptual Framework for Business Enterprises in the United States. Accounting Historians Journal. v. 26, n. 2, December 1999.

EL-ESSELY, Mohamed Ahmed Mohamed. The Conceptual Framework for Financial Accounting and Reporting in the Developing Countries: Empirical Study of the Unified Accounting System in Egypt. These (Doutorado em Ciências Contábeis), Accounting Division, The City University Business School, London, Octuber, 1987.

Establishing Financial Accounting Standards, 1972. Report of the [Wheat] Study on Establishment of Accounting Principles. New York: American Institute of Certified Public Accountants.

FASB. Financial Accounting Standards Board. Discussion Memoranda on the Conceptual Framework for Accounting and Reporting. Consideration of the Report of the Study Group on the Objectives of Financial Statements, Stamford, CT: FASB, June 6, 1974.

Financial Accounting Standards Board. Discussion Memoranda on the Conceptual Framework for Accounting and Reporting. Elements of Financial Statements and Their Measurement. Stamford, CT: FASB, December 2, 1976b.

Financial Accounting Standard Board. Statement of Financial Accounting Concepts No. 1: Objectives of Financial Reporting by Business Enterprises. November 1978 Disponível em: <http://www.fasb.org/pdf/aop_CON1.pdf>. Acesso em: 14 ago. 2014.

Financial Accounting Standard Board. Statement of Financial Accounting Concepts No. 2: Qualitative Characteristics of Accounting Information. May 1980 Disponível em: 〈http://www.fasb.org/pdf/aop_CON2.pdf>. Acesso em: 14 ago. 2014.

Financial Accounting Standard Board. Statement of Financial Accounting Concepts No. 3: Elements of Financial Statements of Business Enterprises. December 1980. Disponível em: <http://www.fasb.org/pdf/aop_CON3.pdf>. Acesso em: 14 ago. 2014.

Financial Accounting Standard Board. Statement of Financial Accounting Concepts No. 4: Objectives of Financial Reporting by Nonbusiness Organizations. December 1980. Disponível em: 〈http://www.fasb.org/pdf/aop_CON4.pdf>. Acesso em: 14 ago. 2014.

Financial Accounting Standard Board. Statement of Financial Accounting Concepts No. 5: Recognition and Measurement in Financial Statements of Business 
Enterprises. December 1984. Disponível em: 〈http://www.fasb.org/pdf/aop_CON5.pdf>. Acesso em: 14 ago. 2014.

Financial Accounting Standard Board. Statement of Financial Accounting Concepts No. 6: Elements of Financial Statements - a replacement of FASB Concepts Statement No. 3 (incorporating an amendment of FASB Concepts Statement No. 2). December 1985. Disponível em: 〈http://www.fasb.org/pdf/aop_CON6.pdf〉. Acesso em: 14 ago. 2014.

Financial Accounting Standard Board. Statement of Financial Accounting Concepts No. 7: Using Cash Flow Information and Present Value in Accounting Measurements. February 2000. Disponível em: <http://www.fasb.org/pdf/aop_CON7.pdf>. Acesso em: 14 ago. 2014.

Financial Accounting Standard Board. Statement of Financial Accounting Concepts No. 8: Conceptual Framework for Financial Reporting - Chapter 1, The Objective of General Purpose Financial Reporting, and Chapter 3, Qualitative Characteristics of Useful Financial Information - a replacement of FASB Concepts Statements No. 1 and No. 2 - September 2010. Disponível em: <http://www.fasb.org/cs/ContentServer?site=FASB\&c=Document_C\&pagename $=$ FASB \%2FDocument_C\%2FDocumentPage\&cid=1176157498129>. Acesso em: 14 ago. 2014.

Financial Accounting Standards Board. Tentative Conclusions on Objectives of Financial Statements for Business Enterprises. Stamford, CT: FASB, December 2, 1976.

FERTIG, P.E. A Statement of Basic Accounting Theory. The New York Certified Public Accountant, September, 37 (9), 1967, 663-671 apud ZEFF, Stephen A. The Objectives of Financial Reporting: A Historical Survey and Analysis. Accounting and Business Research, Vol. 43, No. 4 (International Accounting Policy Forum Issue): 1-66, 2013.

FLOWER, J., European Financial Reporting: Adapting to a Changing World. Houndmills, Basingstoke, Hampshire, UK: Palgrave Macmillan, 2004.

GORE, Pelham. The FASB Conceptual Framework Project 1973-1985: An Analysis. A These (Doutorado em Contabilidade e Finanças), August 1989.

GUJARATI, D. N; PORTER, C. D. Econometria Básica. Porto Alegre: Editora Bookman. 2006.

Healy, R.E. Address before the Harvard Business School Alumni Association at its Ninth Annual Special Meeting, at Baker Library, Harvard Business School, Boston. Typescript, June 16, 1939.

HENDRIKSEN, Eldon S.; VAN BREDA, Michel F. Teoria da contabilidade. Tradução Antonio Zoratto Sanvicente. São Paulo: Atlas, 1999. 550p. 
HINES, Ruth D. The FASB's Conceptual Framework, Financial Accounting and the Maintenance of the Social World. Accounting, Organizations and Society, v. 16, n. 4, pp. 313-331, 1991.

HOLDER, Anthony D; KARIM, Khondkar, E; LIN, Karen Jingrong; WOODS, Maef. A content analysis of the comment letters to the FASB and IASB: Accounting for contingencies. Advances in Accounting. v. 29, n. 1, June 2013, P. 134-153.

IASB. IFRS Foundation and International Accounting Standard Board. Discussion Paper DP/2013/1 - A Review of the Conceptual Framework for Financial Reporting. 2013.

IASB - International Accounting Standard Board. Staff Paper 10M, March 2014, Project Conceptual Framework, Feedback summary: user outreach, 2014a. Disponível em: $<$ http://www.ifrs.org/Current-Projects/IASB-Projects/Conceptual-

ramework/Pages/Conceptual-Framework-Summary.aspx>. Acesso em: 14 ago. 2014.

International Accounting Standard Board. Staff Paper 10A, September 2014, Project Conceptual Framework, Feedback summary: user outreach, 2014b. Disponível em: $\quad<$ http://www.ifrs.org/Current-Projects/IASB-Projects/Conceptualramework/Pages/Conceptual-Framework-Summary.aspx>. Acesso em: 14 ago. 2014.

Intenational Accounting Standard Board. The Conceptual Framework for Financial Reporting. Disponível em: <www.ifrs.org>. Acesso em: 14 ago. 2014.

IATRIDIS, George. International Financial Reporting Standards and the quality of financial statement information. International Review of Financial Analysis, 19, pp. 193-204, 2010.

JOHNSON, L.T. Relevance and reliability. The FASB Report, Financial Accounting Series, $n^{\circ}$. 265, 28 February 2005.

KLANN, R. C.; BEUREN, I. M. Gerenciamento de Resultados: Análise comparativa de empresas brasileiras e inglesas antes e após a adoção das IRFS. Anais do Encontro Nacional da Associação Nacional de Pós-Graduação e Pesquisa em Administração, Rio de Janeiro, RJ, Brasil, 36, Setembro/2010.

KOTHARI, C. R. Research Methodology: Methods \& Techniques. 2 ed. New Delhi: New Age, 2004, 401 p.

LARSON, Faber. Estatística Aplicada. 4 ed. Pearson, 2010.

LARSON, Robert K. An Examination of the Comment Letters to the IASC: Special Purpose Entities. Research in Accounting Regulation, v. 20, p. 27-46, 2008.

LARSON, Robert K.; BROWN, Karen L. Lobbying of the International Accounting Standards Committee: the case of construction contracts. Advances in International Accounting, v. 14, p. 47-73, 2001. 
LEUZ, C.; NANDA, D.; WYSOCKI, P. D. Earnings management and investor protection: an international comparison. Journal of Financial Economics. 69(3), 505-527, 2003.

MAGLIO, R. A Content Based Analysis of Comment Letters on the IASB Discussion Paper Financial Instruments with Characteristics of Equity. SSRN Working Paper Series, Rochester, Rochester, 2011.

MATOS, Eduardo Bona Safe de. Critérios de reconhecimento, mensuração e apresentação das orepações de Leasing segundo a minuta de pronunciamento (ED/2010/9) do IASB: análise da opinião dos usuários da informação contábil. Dissertação (Mestrado em Ciências Contábeis), Programa Multiinstitucional e Inter-regional de Pós-Graduação em Ciências Contábeis da Universidade de Brasília, Universidade Federal da Paraíba e Universidade Federal do Rio Grande do Norte. Brasília: UnB, 2013, 167 p.

MEDEIROS, Marcelo de Almeida; CAMPOS, Cinthia Regina. União Européia, reformas institucionais e défcits democráticos: uma análise a partir do mecanismo co-decisão. Ver. Bras. Polit. Int. 52 (1): 29-52, 2009.

MINAYO, M. C. S. (Org.). Pesquisa social: teoria, método e criatividade. Rio de Janeiro: Vozes, 2001.

MOZZATO, Anelise Rebelato; GRZYBOVSKI, Denize. Análise de Conteúdo como Técnica de Análise de Dados Qualitativos no Campo da Administração: Potencial e Desafios. RAC, Curitiba, v. 15, n. 4, pp. 731-747, Jul./Ago. 2011.

MURCIA, Fernando Dal-Ri. Fatores determinantes do nível de disclosure voluntário de companhias abertas no Brasil. Tese (Doutorado em Contabilidade), Departamento de Contabilidade e Atuaria da Faculdade de Economia, Administração e Contabilidade da Universidade de São Paulo, 2009, 173 p.

NIYAMA, Jorge Katsumi. Contabilidade Internacional. 2 ed. São Paulo: Atlas, 2010, 178p.

; GONÇALVES, Rodrigo de Souza, MATOS, Eduardo Bona Safe de; MARQUES, Matheus de Mendonça. Convergência Internacional: Análise da Relação entre o Processo Normativo e a Composição dos Membros do IASB. XXXVI Encontro da ANPAD, Rio de Janeiro/RJ - 22 a 26 de setembro de 2012.

; RODRIGUES JÚNIOR, José Ribamar Nery; ESPIRIDIÃO, Lorene Duarte; ARAGÃO, Viviane Maria Carneiro. Princípios contábeis europeus e brasileiros: uma abordagem comparativa. Revista Contabilidade, Gestão e Governança, v. 2, n. 1, 1999.

NOBES, Christopher; PARKER, Robert. Comparative International Accounting. 11 ed. England: Person, 2010. 637p.

NUSSBAUMER, Norma. Does The FASB's Conceptual Frmework Help Solve Real Accounting Issues? Journal of Accounting Eductrliom, Vol. 10, pp. pp. 235-242.1992. 
OLIVEIRA, Atelmo Ferreira de. Evolução da terminologia princípio contábil baseada na escola norte-americana. Dissertação (Mestrado em Ciências Contábeis), Programa Multiinstitucional e Inter-regional de Pós-Graduação em Ciências Contábeis da Universidade de Brasília, Universidade Federal da Paraíba, Universidade Federal do Pernambuco e Universidade Federal do Rio Grande do Norte. Natal: UFRN, 2003.173p.

OLIVEIRA, Helio Cincinato; CARVALHO, Rubens Moura. A Quarta e Sétima diretivas da União Européia e suas Implicações sobre a Contabilidade Local do País-Membro: França. EnAnpad, Salvador/BA, 2006.

PAANANEN, M.; LIN, H. The development of accounting quality of IAS and IFRS over time: the case of Germany. Journal of International Accounting Research, v. 8, n. 1, 2009.

PACTER, Paul. What exactly is convergence? Journal Accounting, Auditing and Performance Evaluation, v. 2, n. 1/2, 2005.

PAULO, Edilson. Comparação da estrutura conceitual da contabilidade financeira: experiência brasileira, norte-americana e internacional. Dissertação (Mestrado em Ciências Contábeis) Programa Multiinstitucional e Inter-regional de Pós-Graduação em Ciências Contábeis da Universidade de Brasília, Universidade Federal da Paraíba, Universidade Federal do Pernambuco e Universidade Federal do Rio Grande do Norte. 2002.174p.

Proceeds, Revenue, Income, Profit, and Earnings, Accounting Terminology Bulletin No. 2, in Accounting Research and Terminology Bulletins, Final Edition (New York: American Institute of Certified Public Accountants, 1961): 33-36, 1965.

SAUDAGARAN, Shahrokh M. International Accounting: A User Perspective. 2. ed. CCH: Chicago, 2004.

SCHIPPER, Katherine. Principles-Based Accounting Standards. American Accounting Association, Accounting Horizons, v. 17, n. 1, p. 61-72, 2003.

SCHEID, J. C. \& WALTON, P. European Financial Reporting: France. London, U.K.: Routledge, 1992 apud ZEFF, Stephen A. The Evolution of the IASC into the IASB, and the Challenges it Faces. The Accounting Review, May, 87 (3), 807-837, 2012.

SCHMIDT, Paulo. História do pensamento contábil. Porto Alegre: Bookman, 2000, 231p.

SHIN, Hyun. Disclosures and asset return. Econometrica, v. 71, p. 105-133, 2003.

SKINNER, R. M. 1972. Accounting Principles: A Canadian Viewpoint. Toronto, ON, Canada: Canadian Institute of Chartered Accountants, 1972 apud ZEFF, Stephen A. The Evolution of the IASC into the IASB, and the Challenges it Faces. The Accounting Review, May, 87 (3), 807-837, 2012. 
SOLOMON, Aris. An Investigation into a Conceptual Framework for Corporate Environmental Reporting. Thesis (PhD), Sheffield University Management School Department of Accounting \& Finance, October, 1998.

Task Force appointed to study Conceptual Framework for accounting and reporting: Will meet with members of Trueblood Study Group, 1973. FASB Status Report, no. 8 (December 27), 1-2.

VAN RIPER, Robert. Setting Standards for Financial Reporting: FASB and the Struggle for Control of a Critical Process (Westport, CT: Quorum Books), 1994 apud ZEFF, Stephen A. The Evolution of the Conceptual Framework for Business Enterprises in the United States. Accounting Historians Journal. Vol. 26, No. 2, December 1999.

WALLIMAN, Nicholas. Your research project: a step-by-step guide for the first-time researcher. London: SAGE, 2001, 322 p.

WATTS, Ross L., ZIMMERMAN, Jerold L. Positive Accounting Theory. Englewood Cliffs, NJ: Prentice-Hall, 1986.

WHITTINGTON, Geoffrey. Fair Value and the IASB/FASB Conceptual Framework Project: An Alternative View. ABACUS, Vol. 44, No. 2, 2008.

WOLK, Harry I. Accounting Theory. Volume II. London: SAGE, 2009.

WOLK, Harry I; DODD, James L; TEARNEY, Michael G. Accounting Theory. 6 ed. Thomson, 2004.

XIAO, Zezhong; PAN, Aixiang. Developing Accounting Standards on the Basis of a Conceptual Framework by the Chinese Government. The International Journal of Accounting, Vol. 32, No. 3, pp. 279-299, 1997.

YEN, Alex C.; HIRST, D. Eric; HOPKINS, Patrick E. A Content Analysis of the Comprehensive Income Exposure Draft Coment Letters. Research in Accounting Regulation, v. 19, p. 53-79, 2007.

YOON, Sora. Accounting Quality and International Accounting Convergence.

Dissertação (Doutorado), Oklahoma State University, Dezembro, 2007.

ZEFF, Stephen A. Forging Accounting in Five Countries: A History and Analysis of Trends. Illinois: Stipes Publishing Company, 1972.

IFRS Developments in the USA and EU, and Some Implications for Australia. Australian Accounting Review No. 47 Vol. 18, Issue 4, 2008.

The Evolution of the Conceptual Framework for Business Enterprises in the United States. Accounting Historians Journal. Vol. 26, No. 2, December 1999. 
The Evolution of the IASC into the IASB, and the Challenges it Faces. The Accounting Review, May, 87 (3), 807-837, 2012.

The Objectives of Financial Reporting: A Historical Survey and Analysis. Accounting and Business Research, Vol. 43, No. 4 (International Accounting Policy Forum Issue): 1-66, 2013.

The SEC Rules Historical Cost Accounting: 1934 to the 1970s. Accounting and Business Research, International Accounting Policy Forum. pp. 000-000. 2007.

The Trueblood Study Group on the Objectives of Financial Statement (1971-1973): A historical study. Working paper, Rice University, Agosto, 2014a.

. The Wheat Study on Establishment of Accounting Principles (1971-1972): A historical study. Working paper, Rice University, Setembro, 2014b.

Some Junctures in the Evolution of the Process of Establishing Accounting Principles in the U.S.A.: 1917-1972, Accounting Review, Vol. 59, No. 3: 447-468, 1984.

; CAMFFERMAN, K. Financial Reporting and Global Capital Markets: A History of the International Accounting Standards Committee, 1973-2000. Oxford, U.K.: Oxford University Press, 2007. 
ANEXOS 
ANEXO A - RESUMO DO DISCUSSION PAPER - DP/2013/1

\section{DISCUSSION PAPER - DP/2013/1}

A proposta de alteração da Conceptual Framework for Financial Reporting do IASB segundo o Discussion Paper DP/2013/1, tem por objetivo obter pontos de vista iniciais e comentários sobre diversos assuntos, concentrando-se em áreas que causaram os problemas do IASB na prática, pois, apesar do auxilio fornecido no desenvolvimento e revisão de IFRSs, foram identificados diversos problemas com a estrutura conceitual existente, sendo que, áreas importantes não são cobertas, a orientação em algumas áreas não é clara e alguns aspectos da Estrutura Conceitual existente estão desatualizados e não refletem o pensamento atual do IASB.

Dessa forma o DP/2013/1 está dividido em 9 (nove) seções: 1 - Introdução; 2 - Elementos das demonstrações financeiras; 3 - Orientação adicional de apoio às definições de ativo e passivo; 4 Reconhecimento e desreconhecimento; 5 - Definição de capital próprio e distinção entre passivo e instrumentos de patrimônio; 6 - Mensuração; 7 - Apresentação e divulgação; 8 - Apresentação na demonstração de resultados abrangentes e 9 - Outras Questões.

\section{SEÇÃO 1 - INTRODUÇÃO}

A seção introdutória do DP/2013/1 estabelece a proposta pretendida e o status da Estrutura Conceitual. A Estrutura Conceitual estabelece conceitos que fundamentam a preparação e apresentação das demonstrações financeiras. Seu propósito, como descrito na Estrutura Conceitual existente, é:

$\checkmark \quad$ auxiliar o IASB no desenvolvimento de futuras IFRSs e na revisão de IFRSs existentes;

$\checkmark$ auxiliar o IASB a promover a harmonização de regulamentações, padrões de contabilidade e procedimentos relacionados com a apresentação de demonstrações financeiras ao fornecer uma base para diminuir o número de tratamentos alternativos de contabilidade permitidos pelas IFRSs;

$\checkmark$ auxiliar corpos normativos nacionais a desenvolver normas nacionais;

$\checkmark$ auxiliar auditores a formar uma opinião a respeito das demonstrações financeiras, se elas estão de acordo com as IFRSs;

$\checkmark$ auxiliar os usuários das demonstrações financeiras a interpretar a informação contida nas demonstrações financeiras preparadas conforme as IFRSs; e,

$\checkmark$ fornecer àqueles que estão interessados no trabalho do IASB, informações sobre sua abordagem de formulação de IFRSs.

O IASB acredita que uma longa lista de possíveis usos da Estrutura Conceitual não ajudaria a desenvolver uma Estrutura Conceitual revisada. Ao invés disso, o DP propõe que o propósito primário da Estrutura Conceitual revisada é auxiliar a IASB a identificar os conceitos que usarão consistentemente ao desenvolver e revisar IFRSs. O IASB acredita que focar nas necessidades do IASB ao estabelecer Normas ajudará a fornecer conceitos melhor direcionados para a Estrutura Conceitual revisada.

Em adição, a Estrutura Conceitual exercita um papel importante em auxiliar outras partes além do IASB (por exemplo, preparadores, auditores, regulamentadores e usuários das demonstrações financeiras): a) entender e interpretar as IFRSs existentes e b) desenvolver políticas contábeis quando nenhuma IFRS se aplicar especificamente para determinada transação ou evento.

A Estrutura Conceitual existente não é uma Norma ou Interpretação e não sobrepõe nenhuma Norma ou Interpretação específica. Este Documento de Discussão não propõe a mudança dessa posição. Em um número limitado de casos, pode haver um conflito entre a Estrutura Conceitual e uma Norma. Onde houver um conflito, o requerimento da Norma prevalece sobre a Estrutura Conceitual. Porém, devido a Estrutura Conceitual guiar o IASB na criação e revisão de Normas, os números desses conflitos devem diminuir com o tempo.

\section{SEÇÃO 2 - ELEMENTOS DAS DEMONSTRAÇÕES FINANCEIRAS}

As definições existentes de ativos e passivos são: (a) um ativo: um recurso controlado pela entidade como resultado de eventos passados e dos quais futuros fluxos de benefícios econômicos são esperados para a entidade; e (b) um passivo: uma obrigação presente da entidade decorrente de eventos passados, o ajuste do qual se espera que resulte em uma saída de recursos da entidade, incorporando benefícios econômicos.

Essas definições têm sido úteis para se resolver muitos dos problemas de padronização. Eles focam no fenômeno econômico que existe no mundo real (recursos e obrigações), que são relevantes para os usuários das demonstrações financeiras e que são compreensíveis. Mesmo assim, o IASB acredita que as definições possam 
ser aprimoradas de duas maneiras: 1) confirmando mais explicitamente que: i) um ativo é um recurso (ao invés de uma entrada de benefícios econômicos que os recursos podem gerar); ii) um passivo é uma obrigação (ao invés de uma saída de benefícios econômicos que uma obrigação pode gerar); (iii) um ativo pode ser capaz de gerar uma entrada de benefícios econômicos. Essa entrada não precisa ser certa. A probabilidade dessas entradas não precisa atingir nenhum limiar mínimo antes que o recurso subjacente atenda a definição de ativo; iv) um passivo deve ser capaz de gerar saída de benefícios econômicos. Essas saídas não precisam ser certas. A sua probabilidade não precisa alcançar nenhum limiar mínimo antes que a obrigação subjacente atenda a definição de passivo, e, 2) adicionando à orientação que sustenta as definições de ativos e passivos, para clarificar vários assuntos que causaram dificuldade na revisão ou para fornecer Interpretações para certas Normas.

Devido às definições existentes referirem-se ao fluxo esperado de benefícios econômicos, alguns leitores têm, por vezes, confundido o recurso (ativo) ou a obrigação (passivo) com a resultante entrada e saída dos benefícios econômicos. Dois fatores deram origem à essa confusão em potencial: (a) alguns leitores interpretam o termo 'esperado' como se transmitisse a ideia de limiar. (b) a referência explícita de fluxo de benefícios econômicos obscurece a distinção entre o recurso ou obrigação e o fluxo resultante dos benefícios econômicos.

As definições propostas no DP/2013/1 são: a) um Ativo é um recurso econômico presente controlado pela entidade como resultado de eventos passados; b) um Passivo é uma obrigação presente da entidade de transferir um recurso econômico como resultado de eventos passados; e c) um Recurso Econômico é um direito, ou outra fonte de valor, que é capaz de produzir benefícios econômicos. As orientações dando suporte à definição de um ativo deixaria claro que o ativo é o recurso; e não a futura entrada definitiva.

As definições existentes se referem a eventos passados que trouxeram o recuso para o controle da entidade, ou que impuseram a obrigação à entidade. As definições propostas são: a) reter o termo 'presente' na definição proposta de passivo. Isso enfatiza que, para determinar se um passivo existe ou não, a questão chave é se a entidade tem ou não uma obrigação na data do relatório; b) adicionar o termo 'presente' para a definição proposta de ativo. Essa noção já está implícita na definição existente. Tornando-a explícita enfatiza o paralelo com a definição do passivo; e, c) reter, em ambas as definições, a frase 'como resultado de eventos passados. Isso enfatiza a contabilidade de transações passadas ou outros eventos que trouxeram o recurso sob o controle da entidade ou impuseram a obrigação à entidade.

Na Estrutura Conceitual existente, a incerteza pode parecer desempenhar um papel tanto na definição de ativos e passivos quanto no critério de reconhecimento: a) as definições existentes incluem a noção de que futuros benefícios econômicos (ou uma futura saída de recursos) devem ser 'esperados; e b) os critérios de reconhecimento existentes especificam que um ativo ou passivo é reconhecido se for provável que qualquer benefício econômico futuro associado com o item irá fluir de ou para a entidade. Ao considerar essas questões vale a pena distinguir duas formas de incerteza: a) incerteza sobre se um ativo ou passivo existe (incerteza de existência); e, b) incerteza sobre se um ativo ou passivo irá resultar ou não em uma entrada ou saída (incerteza de resultado).

Em alguns casos raros, não é claro se uma entidade possui um ativo ou um passivo. A incerteza de existência está presente se a existência de um ativo ou passivo é incerta. Impor uma probabilidade limiar explícita na Estrutura Conceitual poderia levar a uma consistência maior nas decisões ao desenvolver ou revisar Normas. Por outro lado, a incerteza de existência é rara - não é necessário estabelecer um princípio para esses poucos casos; permitir o julgamento é apropriado em normas baseadas em princípios; e se a incerteza de existência é relevante em um projeto em particular, o IASB poderia decidir naquele projeto qual limiar, se algum, resultaria na informação mais relevante para usuários das demonstrações financeiras naquele caso específico.

A incerteza de resultado se refere a casos onde o ativo ou passivo existem, mas o resultado é incerto. A incerteza de resultado surge muito mais comumente do que a incerteza de existência. Alguns sugerem que o IASB deveria reter um pouco do limiar de probabilidade, seja na definição de elementos ou nos critérios de reconhecimento, para casos de incerteza de resultado. Eles acham que usuários das demonstrações financeiras não irão considerar alguns resultados de baixa probabilidade nas suas estimativas de montante, tempo, e incerteza de futuras movimentações de caixa.

As visões preliminares do IASB sobre incerteza são de que: a) as definições de ativos e passivos não devem reter a noção de que uma entrada ou saída de caixa é esperada. Reter essa noção pode excluir muitos itens que são claramente ativos e passivos, tais como muitas opções compradas ou escritas; b) em casos raros, é incerto se um ativo ou passivo existe. A Estrutura Conceitual não deve estabelecer um limiar de probabilidade para determinar se um ativo ou positivo existe nesses casos raros; c) a referência da probabilidade deve ser deletada dos critérios de reconhecimento. Incluir um limiar de probabilidade levaria a uma falha no reconhecimento de alguns itens (por exemplo, opções) que são, sem dúvida, ativos ou passivos, mas são julgados, em um período específico, por ter uma probabilidade pequena de resultar em uma entrada ou saída de benefícios econômicos. 
A definição proposta de um recurso econômico esclarece que não é necessária a certeza de que um recurso econômico irá gerar benefícios econômicos, mas o recurso econômico deve ser capaz de produzir benefícios econômicos. As definições não especificariam um limiar mínimo de probabilidade. Semelhantemente, não é necessária a certeza de que uma obrigação presente irá resultar em uma transferência de recursos econômicos.

\section{SEÇÃO 3 - ORIENTAÇÃO ADICIONAL DE APOIO ÀS DEFINIÇÕES DE ATIVO E PASSIVO}

O IASB propõe a definição de um passivo como uma ‘obrigação'. A Estrutura Conceitual existente descreve uma obrigação como "um dever ou responsabilidade de executar ou agir de determinada maneira." Ele então afirma que, apesar das obrigações serem legalmente exequíveis como consequência de um contrato vinculativo ou exigência legal, eles também podem surgir de práticas comerciais normais, costumes e desejo de manter boas relações comerciais ou agir de uma maneira equitativa. A IAS 37 Provisions, Contingent Liabilities and Contingent Assets denota que o passivo pode surgir de uma obrigação legal ou de uma obrigação construtiva, e define o segundo como: Uma obrigação construtiva é uma obrigação que deriva das ações de uma entidade, em que: a) por um padrão estabelecido de práticas passadas, políticas publicadas ou uma declaração atual suficientemente específica, a entidade indicou outras partes que irão aceitar certas responsabilidades; e, b) como resultado, a entidade criou uma expectativa válida, por parte daquelas outras partes, que cumprirão com essas responsabilidades.

A IAS 19 Employee Benefits também se refere às obrigações construtivas - ela exige que as entidades se responsabilizem por ambas as obrigações construtivas e legais em prol de benefícios para os empregados. Ela descreve as obrigações legais decorrentes de termos formais de contratos de trabalho ou planos de benefícios, e as obrigações construtivas decorrentes das práticas informais da entidade. Ela afirma que as práticas informais, tais como o pagamento de bônus em excesso daqueles a que os empregados estão contratualmente favorecidos, dão origem a uma obrigação construtiva se deixarem a empresa sem alternativa real a não ser o pagamento dos benefícios, por exemplo, se uma mudança nessas práticas fosse causar um dano inaceitável ao relacionamento da entidade com seus empregados.

O IASB propõe a definição de um passivo como uma obrigação 'presente' de transferir um recurso econômico como resultado de eventos passados. Uma obrigação presente é a que existe na data de registro. $\mathrm{O}$ Recurso econômico a ser transferido não precisa existir na data, nem precisa estar sob o controle da entidade já na data. Em vários casos, uma entidade tem a obrigação presente de que irá cumprir com recursos econômicos que irão adquirir no futuro. Para identificar um passivo é necessário distinguir entre obrigações presentes e possíveis obrigações futuras. Uma obrigação presente deve ter surgido como um resultado de eventos passados.

Contudo são encontradas dificuldades na prática devido à falta de clareza se esses eventos passados são suficientes para criar uma obrigação presente de transferência de um recurso econômico se tal transferência se mantiver condicional a eventos futuros que não ocorreram, ou ações adicionais que a entidade não realizou, até a data de registro. Essas dificuldades surgiram tanto para o IASB, ao desenvolver novas Normas, quanto para o Comitê de Interpretações e outros, ao interpretar as Normas existentes. As dificuldades frequentes sugeriam que a Estrutura Conceitual existente não é suficientemente clara nessa área e que orientações adicionais são necessárias.

Pode haver dois tipos de eventos futuros nos quais uma obrigação permanece condicional: a) aqueles dos quais a ocorrência está fora do controle da entidade; e, b) aqueles dos quais a ocorrência depende das ações futuras da entidade.

Três visões alternativas são discutidas e propostas pelo IASB. A Visão 1, é que uma obrigação presente deve surgir de eventos passados e ser estritamente incondicional. A quantia de uma transferência futura pode ser determinada pela referência com as atividades passadas da entidade. Mas, enquanto a entidade puder, pelo menos em teoria, evitar a transferência de recursos através de suas ações futuras, ela não tem uma obrigação presente. Em outras palavras, se uma entidade deve tomar uma série de ações antes que tenha uma obrigação incondicional, nenhum passivo existe, até que todas essas ações sejam tomadas. O IASB tem, provisoriamente, rejeitado a Visão 1. Porém, ele ainda não chegou a uma visão preliminar em favor da Visão 2 ou da Visão 3.

A Visão 2 afirma que uma obrigação presente deve originar de eventos passados e ser praticamente incondicional. A visão 1 exige que a obrigação presente seja estritamente incondicional. Ela identifica a presença da obrigação por referência até o fim na série de ações que a entidade deve tomar antes que seja incondicionalmente necessária a transferência de um recurso para outra parte. Entretanto, a última ação pode ser relativamente menor - uma condição incidental que pode ter alguma substância comercial, mas que a entidade não possui capacidade prática para evitar em suas circunstâncias individuais.

Já na Visão 3, uma obrigação presente deve originar de eventos passados mas pode ser condicional em ações futuras da entidade. As duas primeiras visões discutidas nessa seção explicam-se da seguinte forma: para uma obrigação presente existir, não é suficiente que a entidade tenha recebido um recurso econômico, ou 
conduzido uma atividade na qual a quantia de possíveis transferências futuras será determinada. Também é necessário que a obrigação não seja estritamente condicional (Visão 1) ou praticamente incondicional (Visão 2). Uma visão alternativa é aquela em que os eventos passados são suficientes para criar uma obrigação presente: não é necessário que a obrigação seja (estritamente ou praticamente) incondicional. Uma obrigação surge quando a entidade recebe um recurso ou conduz uma atividade, na medida em que outra parte consiga exigir uma transferência de recursos se a entidade atender condições adicionais.

\section{SEÇÃO 4 - RECONHECIMENTO E DESRECONHECIMENTO}

A Estrutura Conceitual existente define Reconhecimento como o processo de se incorporar, no balanço geral ou demonstração de lucros e perdas que um item que está de acordo com a definição de um elemento e atende aos critérios de reconhecimento dispostos na [Estrutura Conceitual existente]. Isso envolve a representação do item em palavras e por uma quantia monetária e a inclusão dessa quantia nos totais do balanço geral ou demonstração de lucros e perdas.

A IFRS 9 Financial Instruments define o desreconhecimento como a remoção de um ativo ou passivo financeiro anteriormente reconhecido da demonstração de posição financeira de uma entidade.

Parte da informação que é útil aos usuários das demonstrações financeiras, para suas decisões sobre fornecer recursos para uma entidade, é a informação sobre os recursos e obrigações de uma entidade e sobre o quão eficientemente a administração e o conselho administrativo da entidade têm cumprido com suas responsabilidades no uso dos recursos da entidade. A maneira mais compreensível e concisa de fornecer um resumo completo dos recursos e obrigações da entidade é reconhecer a todos em uma demonstração de posição financeira, a não ser que o IASB identifique razões válidas para se fazer o contrário.

A informação é relevante para os usuários das demonstrações financeiras se ela for capaz de fazer diferença nas decisões feitas por esses usuários. Na maior parte dos casos, reconhecer recursos e obrigações fornece informações relevantes aos usuários das demonstrações financeiras, mas em alguns casos, isso pode fornecer informações que não são relevantes, ou que não possuem relevância suficiente para justificar os seus custos: a) se o nível de incerteza em uma estimativa é muito grande, a relevância dessa estimativa é questionável. Em tais circunstâncias, se nenhuma outra medida disponível do ativo ou passivo forneça informação relevante aos usuários das demonstrações financeiras, será apropriado não reconhecer o ativo ou passivo, e, b) reconhecer recursos e obrigações específicas pode produzir informação que alguns podem ver como irrelevante, incompleta ou não compreensível se os recursos e obrigações relacionados também não forem reconhecidos, ou não existirem ainda. Na visão preliminar do IASB, a Estrutura Conceitual deveria afirmar que o IASB não exige o reconhecimento de um ativo ou passivo se o IASB concluir que o reconhecimento desse ativo ou passivo resultaria em informação que é irrelevante, ou insuficientemente relevante para justificar os custos de se prepará-la.

Os critérios de reconhecimento na Estrutura Conceitual existente afirmam que uma entidade reconhece um ativo ou passivo apenas se ele tiver um custo ou valor que possa ser mensurado com confiabilidade. A informação é confiável quando for completa, neutra e livre de erros. De acordo com a proposta do DP/2013/1, não se deve reconhecer ativos e passivos, se nenhuma mensuração do ativo (ou passivo) resultará em uma representação fiel tanto do ativo (ou passivo) quanto das mudanças no ativo (ou passivo), mesmo se todas as descrições e explicações necessárias forem divulgadas.

A Estrutura Conceitual existente não define o desreconhecimento e não descreve quando o desreconhecimento deve ocorrer. Devido à inexistência de concordância acerca de uma abordagem conceitual sobre o desreconhecimento, Normas diferentes têm adotado abordagens diferentes. Isso gera o risco de inconsistência, com o risco adicional de se adotar abordagens baseadas em regras ao invés de abordagens baseadas em princípios.

Existem duas abordagens para o desreconhecimento: a) uma abordagem de controle: o desreconhecimento é simplesmente o oposto do reconhecimento. Portanto, uma entidade desreconheceria um ativo ou passivo quando ele deixa de atender aos critérios de reconhecimento (ou deixarem de existir, ou se não for mais um ativo ou passivo da entidade). Isso implica que os critérios de desreconhecimento de um ativo focariam no controle do ativo (ao invés da posse legal ou nos riscos e recompensas) e os critérios de desreconhecimento de um passivo focaria em se a entidade ainda possui o passivo; e, b) uma abordagem de risco-e-recompensa: uma entidade deve continuar a reconhecer um ativo ou passivo até que ele não seja mais exposto à maioria dos riscos e recompensas geradas por aquele ativo ou passivo, mesmo que o ativo (ou passivo) remanescente não se qualifique para o reconhecimento, se adquirido (ou incorrido) separadamente na data em que a entidade se dispôs dos outros componentes. Desse modo, se uma entidade reconhece ou não um ativo ou passivo depende, em algumas circunstâncias, se a entidade previamente reconheceu aquele ativo ou passivo. Como resultado, alguns usam os rótulos de 'assuntos históricos' ou 'aderência' para uma abordagem de risco-e-recompensa.

O desreconhecimento deve ocorrer quando uma transação elimina alguns, mas não todos os direitos e 
obrigações contidos em um ativo (ou passivo). Se o desreconhecimento de fato ocorrer, uma questão relacionada é como contabilizar pelos direitos e obrigações retidos. Duas abordagens podem ser consideradas em tais casos: a) desreconhecimento pleno: desreconhece o ativo (ou passivo) por completo e reconhece o componente retido como um novo ativo (ou passivo). Se a quantia armazenada no componente retido diferir de sua quantia armazenada prévia, um ganho ou perda irá surgir desse componente; e, b) desreconhecimento parcial: continua a reconhecer o componente retido e desreconhece o componente que não é retido. No componente retido, não surgirá nenhum ganho e, a não ser que o componente seja debilitado, não surgirá nenhuma perda.

\section{SEÇÃO 5 - DEFINIÇÃO DE CAPITAL PRÓPRIO E DISTINÇÃO ENTRE PASSIVO E INSTRUMENTOS DE PATRIMÔNIO}

A Estrutura Conceitual existente define patrimônio líquido como o interesse residual nos ativos de uma entidade após a dedução de todos os seus passivos. A visão preliminar do IASB é de que ele não deve mudar essa definição. O total do patrimônio líquido é igual ao total dos ativos, menos o total dos passivos, como reconhecido e mensurado nas demonstrações financeiras. Ele não representa o valor da entidade.

A distinção entre passivos financeiros e instrumentos de patrimônio é, atualmente, governada pela IAS 32 e IFRS 2. A IAS 32 é complementada pelo IFRIC 2 Members's Shares in Co-operative Entities and Similiar Instruments. Em ambas as IAS 32 e IFRS 2, o ponto de início é determinar se a entidade possui ou não uma obrigação de transferir recursos econômico, mas não existem exceções para esse princípio básico. A distinção na IFRS 2 (entre operações de pagamento liquidadas em dinheiro ou liquidadas em patrimônio líquido baseado em ações) se baseia quase que inteiramente na definição existente na Estrutura Conceitual de um passivo. A IFRS 2 realiza um ajuste nessa definição, para abordar transações para as quais a obrigação reside na entidade ou outra parte relacionada de um outro grupo. Em contraste, a IAS 32 sobrescreve a definição com complexas exceções.

Em seu projeto de parceria sobre os instrumentos financeiros com características de patrimônio líquido, o qual foi suspenso em 2010, o IASB e o FASB decidiram usar, provisoriamente, uma abordagem que classifica, assim como a IAS 32: a) instrumentos como instrumentos de patrimônio, mesmo que eles criem obrigações ao transferir recursos econômicos; e, b) outros instrumentos como os passivos financeiros, mesmo que eles não criem obrigações ao transferir recursos econômicos. As abordagens em ambos o IAS 32 e o projeto FICE podem ser vistos como substituindo a definição de passivo na Estrutura Conceitual existente, com várias exceções. O DP/2013/1 identifica duas abordagens que poderiam simplificar a distinção entre passivos e ativos: uma abordagem de patrimônio líquido estreita e uma abordagem de obrigações rigorosa.

A abordagem de obrigações rigorosa vai: a) classificar como passivos apenas as obrigações de entregar recursos econômicos. Logo, a representação de posição financeira irá mostrar os recursos econômicos e as obrigações de entregar recursos econômicos da entidade; b) classificar como patrimônio líquido todas as reivindicações de patrimônio, em outras palavras: i) todas as reivindicações que dão ao proprietário o direito de receber uma porção de qualquer distribuição de capital feita aos titulares dessa classe de reivindicação; e, ii) todas as obrigações de entregar instrumentos de patrimônio; e, c) como sugerido no parágrafo 5.13, realocar o total de patrimônio ao atualizar a mensuração de todas reivindicações de patrimônio líquido. Logo: i) a seção de patrimônio líquido na demonstração de posição financeira irá mostrar como todas as reivindicações de patrimônio líquido afetam outras reivindicações de patrimônio; e, ii) a demonstração de mudanças no patrimônio líquido mostram as transferências de riqueza entre as diferentes classes de reivindicações de patrimônio.

A abordagem de patrimônio líquido estreita seria: a) classificar como patrimônio líquido apenas instrumentos de patrimônio existentes nas classes mais residual de instrumentos de patrimônio existentes emitidos pela matriz (Definir a classe mais residual pode exigir um trabalho detalhado ao desenvolver ou revisar Normas específicas); b) classificar como passivos todos os outros instrumentos, tais como: i) instrumentos que não criam obrigações ao transferir ativos; ii) NCI; e, iii) prazos e opções nesses instrumentos de patrimônio que são classificados como patrimônio líquido pelo critério em (a); e c) reconhecer os ganhos e perdas nos lucros ou perdas (incluindo, se aplicável, despesas de juros) em todos instrumentos classificados como passivos financeiros.

Investidores existentes e potenciais precisam de informação para auxiliá-los a avaliar as estimativas de fluxo de caixa líquido para uma entidade. Além disso, informações sobre prioridades e exigências de pagamentos de reivindicações existentes auxiliam os usuários das demonstrações financeiras a estimar como o futuro fluxo de caixa será distribuído àqueles com uma reivindicação contra a entidade. Para atender as necessidades dos usuários o DP/2013/1 explora uma abordagem na qual a entidade pode fornecer: a) informação para auxiliar os investidores a avaliar a mensuração, tempestividade e incerteza de futuros fluxos de caixa líquido para a entidade: nas demonstrações de posição financeira, lucro ou perda e outros resultados abrangentes (OCI), fluxos de caixa e nos títulos; e, b) informações sobre as reivindicações nesses fluxos de 
caixa líquido; na demonstração de posição financeira e na demonstração de mudanças do patrimônio líquido.

Isso pode ser alcançado a desenvolver uma demonstração de mudanças no patrimônio líquido da seguinte maneira: a) a demonstração de mudanças no patrimônio líquido demonstraria uma coluna separada para cada classe de reivindicação de equivalência patrimonial. Uma entidade incluiria reivindicações de patrimônio líquido juntas na mesma classe se eles possuírem os mesmos (ou talvez similares) direitos; b) a coluna para cada classe de reivindicação de equivalência patrimonial seria subdividia (na frente da demonstração ou nas notas), se aplicável, em categorias em uma base consistente com as exigências jurídicas e outras exigências governando a entidade. Dependendo destas exigências, exemplos de tais categorias podem incluir porção de capital, recebimentos retidos e reservas; c) uma entidade, ao final de cada período, atualizaria a mensuração de cada classe de reivindicação de equivalência patrimonial. Isso atualizaria a alocação do patrimônio líquido total entre as classes de reivindicação de equivalência patrimonial, mas não afetaria o patrimônio líquido total; e, d) atualizar as mensurações de diferentes classes de patrimônio líquido resultaria em uma transferência entre as quantias de ativos líquidos reconhecidos (ativos menos passivos) atribuídos a essas classes. Isso representa a transferência de riqueza entre essas classes. Em outras palavras, elas mostram como cada classe de reivindicação de equivalência patrimonial diluíram os ativos líquidos atribuíveis a outras classes de reivindicação de equivalência patrimonial durante o período.

O IASB exige que uma entidade classifique alguns instrumentos com opção de venda como instrumentos de patrimônio, mesmo que eles criem uma obrigação de transferir ativos, e, portanto, atendem as definições de um passivo financeiro. A Estrutura Conceitual revisada deve indicar que a entidade deve tratar algumas de suas obrigações que obrigam o emissor a entregar um recurso econômico como se fosse um instrumento de patrimônio. As classes mais subordinadas de instrumentos emitidos por uma entidade podem qualificar como instrumentos de patrimônio sob a abordagem de patrimônio líquido estreita.

\section{SEÇÃO 6 - MENSURAÇÃO}

O objetivo das demonstrações financeiras é fornecer informação financeira sobre a entidade participante que é útil para investidores existentes e potenciais, mutuantes e outros credores a tomar decisões sobre fornecer recursos para a entidade. Informação financeira que é útil incluem informações sobre os recursos da entidade, reivindicações contra a entidade, e quão eficiente e efetivamente a administração e o conselho administrativo da entidade têm cumprido suas responsabilidades no uso dos recursos da entidade.

Aplicando o objetivo das demonstrações financeiras às mensurações, a visão preliminar do IASB é de que o objetivo das mensurações é contribuir para a representação fiel de informação relevante sobre os recursos da entidade, reivindicações contra e entidade e mudanças nos recursos e reivindicações.

Mensurar todos os ativos e passivos na mesma base resultaria nas quantias, nas demonstrações financeiras terem o mesmo significado, o que faria os totais e subtotais mais compreensíveis do que aqueles em demonstrações financeiras preparadas sob as exigências existentes. Contudo, mensurar todos ativos e passivos em uma base de custo pode não fornecer informações relevantes aos usuários das demonstrações financeiras. A visão preliminar do IASB é que a Estrutura Conceitual não deve recomendar a mensuração de todos os ativos e passivos na mesma base.

A maneira pela qual um ativo ou passivo pode contribuir para os futuros fluxos de caixa afetam a maneira como usuários das demonstrações financeiras avaliam as estimativas para entradas de caixa líquido para a entidade. Dessa forma, a visão preliminar do IASB é que a seleção de uma mensura para um ativo específico deve depender de como ele contribui para futuros fluxos de caixa, e, para um passivo específico, deve depender de como a entidade irá liquidar ou cumprir esse passivo.

A característica qualitativa da compreensibilidade também possui uma implicação importante ao definir as exigências de mensuração. Os usuários das demonstrações financeiras precisam ser capazes de entender a mensura utilizada. Quanto mais mensurações forem utilizadas, e quanto mais mudanças existirem nos tipos de mensurações usadas para itens específicos, mais difícil será compreender como essas mensurações interagem para representar a posição financeira e desempenho financeiro da entidade. Consequentemente, a visão preliminar do IASB é que ele deve limitar o número de mensurações utilizadas para o menor número necessário para que se forneça uma informação relevante. Comparabilidade sugere o uso de mensurações que são as mesmas entre períodos e entre entidades. Usar um número menor de mensurações, contribuiria para a comparabilidade.

A restrição de custo descrita na Estrutura Conceitual também deve influenciar as decisões do IASB sobre exigências de mensuração. Ao mesmo tempo, mesmo que uma mensuração seja, potencialmente, a mais relevante, o benefício aos usuários das demonstrações financeiras diminui na medida em que se torna mais subjetiva - e assim, de produção mais onerosa. Infelizmente, uma mensuração sem subjetividade pode não ser relevante. Os benefícios de uma mensuração específica para os usuários das demonstrações financeiras precisam ser suficientes para justificar o seu custo.

A relevância de uma mensuração específica irá depender de quão provável os investidores, mutuantes e 
outros credores irão avaliar como um ativo desse tipo irá contribuir para os futuros fluxos de caixa da entidade. Consequentemente, a visão preliminar do IASB é que a mensuração usada para um ativo específico não deve depender de como ele contribui para os futuros fluxos de caixa. Alguns ativos contribuem indiretamente para os futuros fluxos de caixa ao serem usados. Mensurar um ativo que gera fluxo de caixa indiretamente a um preço de mercado atual não fornece, necessariamente, a melhor informação sobre o fluxo de caixa que esse ativo irá gerar. Para ativos utilizados pela entidade, mensurações baseadas em custo normalmente resultam em receita e despesas que são mais relevantes e compreensíveis que receitas e despesas geradas pelos preços de venda do mercado atual.

Um ativo ao ser vendido irá produzir um fluxo de caixa direto, o que, na maioria dos casos, sugere que é provável que o preço de saída atual - ou talvez um preço de saída atual menos custo de venda - seja relevante. $\mathrm{O}$ custo de obter um preço de saída atual seria justificado, provavelmente, e em muitos casos não seria particularmente alto.

O DP/2013/1 sugere que o preço de saída atual é a mensuração mais apropriada para ativos que serão realizados através da venda, tais como investimentos em instrumentos financeiros - se não for ser mantido para coleta -, mercadorias comercializadas tais como metais preciosos ou grãos, e ativos físicos, além de inventários, que irão ser vendidos.

Os termos de muitos instrumentos financeiros exigem que o emissor faça pagamentos ou entregue outros instrumentos financeiros. Apesar de que muitos, se não todos, possam ser vendidos, uma entidade pode mantê-los e coletar o fluxo de caixa contratual. Os empréstimos, vínculos e outros recebíveis que possuem retornos como interesse e variabilidade insignificantes nos fluxos de caixa contratuais são frequentemente mantidos para coleta. A economia desses ativos é significativamente influenciada por dois fatores - o rendimento efetivo e a cobrabilidade. Pode-se esperar que os usuários das demonstrações financeiras avaliem as expectativas futuras de rendimento ao analisar o sucesso passado da administração em originar ou comprar empréstimos rentáveis ou outros recebíveis. A cobrabilidade - ou a falta dela - é sempre relevante. Entrada de juros baseados em custo, junto com despesas de débitos ruins como estimadas pela administração provavelmente fornecerão a informação mais relevante sobre o rendimento efetivo e a cobrabilidade. Se o ativo financeiro possui uma variabilidade insignificantes nos fluxos de caixa contratuais, e são mantidos para coleta, uma mensuração baseada em custo provavelmente fornecerá uma informação relevante.

Titulares de ativos líquidos ou propriedades intelectuais algumas vezes cobram pelo direito de uso desses ativos. Algumas maneiras de gerar tais fluxos de caixa são arrendando, alugando, franquiando e cobrando taxas de entrada, estacionando, pousando ou taxas de ancoragem, pedágios ou royalties. Se uma entidade cobra pelo uso de ativos, a relevância de uma mensuração específica desses ativos dependerá da significância do ativo individual para entidade.

Da mesma maneira que é para ativos, a natureza do passivo e a maneira pela qual será cumprido são importantes para identificar a mensuração apropriada para esse passivo. Passivos caem em dois grupos aqueles com os termos apresentados e aqueles sem termos apresentados. Passivos sem termos apresentados podem surgir de atos ilícitos ou violações de leis ou regulamentos. Passivos desse tipo exigem negociação ou ação judicial para determinar a quantia de liquidação. Para passivos sem termos apresentados, a mensuração baseada em custo não é possível (porque o passivo não tem um custo) e os preços de mercado atuais provavelmente serão difíceis de determinar. Consequentemente, uma mensuração baseada em fluxo de caixa pode ser a única opção possível para passivos sem termos apresentados.

É provável que a maioria dos passivos possua termos contratuais que especifiquem pagamentos, e quase todos são liquidados de acordo com o seus termos. Poucos passivos podem ser transferidos para outras entidades em um mercado imediato. Se um passivo não pode ser transferido, então mensurar esse passivo a um preço de mercado atual reflete, nos resultados abrangentes, uma mudança nos preços de mercado que pode, em muitos casos, não ser percebida e pode reverter sobre a vida do passivo. E uma mensuração baseada em custo irá normalmente fornecer a informação mais relevante sobre passivos que serão liquidados de acordo com os seus termos. Alguns têm argumentado que um preço de mercado atual é a mensuração apropriada para pelo menos alguns passivos financeiros com termos especificados porque os efeitos das mudanças nos preços de mercado (especialmente os efeitos de mudança nas taxas de juros) compensam os efeitos nas mudanças nos preços de mercado de ativos financeiros que não são mensurados usando um preço de mercado atual.

Para alguns ativos e passivos financeiros (por exemplo, derivativos), basear a mensuração na maneira pela qual os ativos contribuem para os futuros fluxos de caixa, ou a maneira pela qual o passivo é liquidado ou cumprido, podem não fornecer informação que é útil ao avaliar estimativas de futuros fluxos de caixa. Por exemplo, esse pode ser o caso: a) se o fluxo de caixa definitivo não está proximamente ligado ao custo original; b) se, devido à variabilidade significativa de fluxos de caixa contratuais, as técnicas de mensuração baseadas em custo podem não funcionar porque elas seriam incapazes de simplesmente alocar pagamentos de juros sobre a vida de tal ativo ou passivo financeiro; ou, c) se mudanças nos fatores de mercado têm um efeito desproporcional no valor do ativo ou do passivo (i.e. o ativo ou passivo é altamente alavancado). Assim sendo, é provável que os preços de mercado atuais sejam a mensuração mais relevante para ativos ou passivos desse 
tipo.

\section{SEÇÃO 7 - APRESENTAÇÃO E DIVULGAÇÃO}

A apresentação e a divulgação são mecanismos pelos quais uma entidade participante comunica informações sobre sua posição financeira e desempenho financeiro para os usuários das demonstrações financeiras. Apresentação e divulgação não são abordadas na Estrutura Conceitual existente. Alguns acreditam que isso levou a exigências em divulgação na IFRS que nem sempre são focados nas divulgações corretas e são muito volumosas.

No contexto da demonstração financeira, o termo 'apresentação' atrai diferentes significados. Segundo o IASB (2011, IAS 1), a base de apresentação de demonstrações financeiras para fins gerais para garantir a comparabilidade tanto com as demonstrações financeiras de períodos anteriores da entidade quanto com as demonstrações financeiras de outras entidades.

No DP/2013/1 o termo apresentação é usado no sentido de divulgação de demonstração financeira no rosto da demonstração financeira primária da entidade. A divulgação possui um sentido mais amplo do que a apresentação. Divulgação é o processo de fornecer informação financeira útil para os usuários sobre a entidade participante. As demonstrações financeiras, incluindo as quantias e descrições apresentadas nas demonstrações financeiras primárias e a informação incluída nas notas às demonstrações financeiras, são, como um todo, uma forma de divulgação. Coletivamente, as demonstrações financeiras representam a visão da posição financeira e desempenho financeiro da entidade.

As demonstrações financeiras primárias são: a) a demonstração de posição financeira; b) a demonstração de lucro e prejuízo e OCI (ou demonstração de lucros ou perdas e a demonstração de resultados abrangentes); c) a demonstração de alterações no capital; e, d) a demonstração de fluxo de caixa.

Com base nos objetivos do relatório contábil no Capítulo 1 da Estrutura Conceitual, o DP/2013/1 propõe que o objetivo das demonstrações financeiras primárias é fornecer uma informação resumida sobre ativos, passivos, patrimônio líquido, receita, despesa, alterações no capital e fluxos de caixa reconhecidos que foram classificados e agregados de uma maneira útil para os usuários das demonstrações financeiras ao tomarem decisões sobre fornecer recursos para entidade.

As demonstrações financeiras primárias não incluem ativos e passivos não reconhecidos e apenas fornecem uma visão resumida dos elementos reconhecidos.

A classificação é a ordenação de itens baseando-se nas qualidades compartilhadas. Agregação envolve a soma desses itens individuais dentro dessas classificações. Para apresentar uma informação que é compreensível na demonstração financeira primária, uma entidade classifica e agrega a informação sobre elementos reconhecidos e os apresentam em uma base resumida.

Se aplicada corretamente, a agregação pode tornar as demonstrações financeiras primárias mais compreensíveis ao resumir um grande volume de informação. Contudo, agregar a informação resulta em uma perda de informação detalhada. Aplicada indevidamente, a agregação pode obscurecer informações úteis ou até mesmo resultar em uma informação enganosa, por exemplo, quando itens diferentes são agregados. Consequentemente, demonstrações financeiras deve agregar informação de forma que a informação útil não seja obscurecida pela inclusão de uma grande quantia de detalhes insignificativos e nem pela agregação de itens que possuem características diferentes.

Devido à compensação combinar itens diferentes (ativos/passivos, receita/despesas, recebimentos de caixa/pagamentos de caixa, contribuições ao capital/distribuição de capital), o IASB acredita que ela não irá fornecer, geralmente, a informação mais útil para avaliar a posição financeira e desempenho financeiro de uma entidade. Contudo, o IASB pode escolher exigir a compensação quando tal apresentação fornecer uma representação mais fiel de uma posição, transação ou outro evento em particular. Ele também pode escolher permitir a compensação quando considerar necessário por razões de custo benefício.

Nenhuma demonstração financeira primária possui prioridade sobre outras demonstrações primárias e elas deveriam ser visualizadas ao mesmo tempo. A maneira pela qual itens são apresentados nas demonstrações financeiras primárias auxilia aos usuários das demonstrações financeiras a receber uma visão geral da posição e desempenho financeiro da entidade.

As notas às demonstrações financeiras apoiam as demonstrações financeiras primárias. Consequentemente, baseados no objetivo do relatório contábil e o objetivo das demonstrações financeiras primárias propostas no DP/2013/1, o objetivo das notas às demonstrações financeiras é complementar as demonstrações financeiras primárias ao fornecer informações úteis adicionais sobre: a) os ativos, passivos, patrimônio líquido, receita, despesas, alterações de capital e fluxos de caixa da entidade; e, b) o quão eficientemente e efetivamente a administração da entidade e o comitê administrativo têm cumprido com suas responsabilidades no uso dos recursos da entidade.

$\mathrm{Na}$ definição das orientações de divulgação nas IFRSs, o objetivo não é que as entidades forneçam informação que permita um usuário das demonstrações financeiras recalcular as quantias reconhecidas nas 
demonstrações financeiras primárias. Ao invés disso, as orientações de divulgação precisam resultar em entidades fornecendo informação suficiente para permitir que um usuário das demonstrações financeiras identifique os principais motores da posição e desempenho financeiro da entidade e compreender os principais riscos emergindo de seus ativos e passivos, e os principais fatores que causam incertezas sobre mensurações usadas nas demonstrações financeiras.

A informação fornecida pelas notas às demonstrações financeiras precisam auxiliar os usuários das demonstrações financeiras a entender a quantia, tempestividade e incerteza de uma futura entrada de caixa líquido.

O DP/2013/1 propõe que, para atender os objetivos das notas às demonstrações financeiras, a Estrutura Conceitual deveria identificar as seguintes divulgações que o IASB consideraria, normalmente, exigir em uma Norma geral sobre divulgação - tal como a IAS 1 - ou em Normas específicas: a) informação sobre a entidade participante como um todo, até o ponto necessário para a compreender: i) os ativos, passivos, patrimônio líquido, receita, despesas, alterações de capital e fluxos de caixa da entidade; e, ii) o quão eficientemente e efetivamente a administração da entidade e o comitê administrativo têm cumprido com suas responsabilidades para usar os ativos da entidade; b) as quantias reconhecidas nas demonstrações financeiras primárias da entidade, incluindo mudanças nessas quantias, por exemplo, desagregação de itens de linha, prorrogações e reconciliações; c) a natureza e extensão dos ativos e passivos não reconhecidos da entidade; d) a natureza e extensão dos riscos emergindo dos ativos e passivos da entidade (sejam eles reconhecidos ou não reconhecidos); e, e) os métodos, suposições e julgamentos e mudanças nesses métodos, suposições e julgamentos, que afetam as quantias apresentadas ou de outra forma divulgadas.

A IAS 1 estabelece que uma entidade não precisa fornecer uma divulgação específica exigida por uma Norma se a informação não for material. Deve-se fornecer divulgações adicionais quando o cumprimento das exigências específicas em uma IFRS for insuficiente para possibilitar aos usuários das demonstrações financeiras o entendimento do impacto de transações específicas, outros eventos e condições na posição e desempenho financeiro da entidade.

A informação é material se a omissão ou a declaração errada puder influenciar decisões que os usuários fazem com base na informação financeira sobre uma entidade participante específica. Em outras palavras, a materialidade é um aspecto da relevância específico à entidade baseado na natureza ou magnitude, ou ambos, dos itens para os quais a informação relaciona no contexto do relatório contábil de uma entidade individual. Consequentemente, o Conselho não pode especificar um limiar quantitativo uniforme para materialidade ou predeterminar o que pode ser material em uma determinada situação. O IASB acredita que o conceito de materialidade é claramente descrito na Estrutura Conceitual existente. Consequentemente, o IASB não se propõe a modificar, ou adicionar, a essa descrição.

Ao desenvolver orientações de divulgação nas IFRSs, o IASB não precisa considerar apenas qual informação seria útil nas circunstâncias de uma ampla gama de entidades, mas deveria, também, desenvolver uma orientação que promova a comunicação eficiente dessa informação. O DP/2013/1 propõe que o IASB deve considerar os seguintes princípios de comunicação ao estabelecer requerimentos de divulgação: a) orientação de divulgação deve procurar promover a divulgação de informação útil que é específica à entidade; b) a orientação de divulgação deveria resultar em divulgações que são claras, balanceadas e compreensíveis; c) a orientação de divulgação deve possibilitar que uma entidade organize divulgações de uma maneira que destaque para o usuário das demonstrações financeiras o que é importante; d) as divulgações devem ser vinculadas. As orientações de divulgação na IFRS deveriam, portanto, resultar em divulgações que auxiliem os usuários das demonstrações financeiras a entender o relacionamento entre os itens da demonstração financeira primária e a informação divulgada nas notas; e) orientação de divulgação não deve resultar na duplicação da mesma informação em partes diferentes das demonstrações financeiras; e, f) a orientação de divulgação deve procurar otimizar a comparabilidade sem comprometer a utilidade da divulgação divulgada.

\section{SEÇÃO 8 - APRESENTAÇ̃̃O NA DEMONSTRAÇÃO DE RESULTADOS ABRANGENTES - LUCROS E PERDAS E OUTROS RESULTADOS ABRANGENTES (OCI - OTHER COMPREHENSIVE INCOME)}

Os respondentes da Consulta de Agenda 2011 do IASB identificaram o relatório da demonstração financeira, incluindo o uso de $\mathrm{OCI}$ e reciclagem, como tópico prioritário que o IASB deveria abordar.

O propósito da demonstração de lucros ou perdas e OCI é representar uma informação resumida sobre itens reconhecidos de receita e despesa que podem ter sido classificados e agregados em uma maneira que é útil para os usuários das demonstrações financeiras ao tomar decisões sobre fornecer recursos para uma entidade.

A maior parte dos itens de receita e despesa está incluída nos lucros ou perdas, incluindo aqueles que resultam do reconhecimento inicial e de outras transações e eventos tais como o consumo de ativos, satisfação de desempenho, obrigações prejuízo. Isso significa que o lucro ou perda inclui todas as quantias resultadas das mensurações baseadas em custo e a maioria dos ganhos e perdas realizados. Alguns outros itens, a maioria ganhos e perdas não realizadas como resultado de recálculos, são incluídos em OCI. Alguns ganhos e perdas 
reconhecidos em OCI são reclassificados para lucros ou perdas quando realizados ou em um momento especificado por Normas específicas. Tal reclassificação é, algumas vezes, chamada de reciclagem.

O IASB foi persuadido pelos argumentos estabelecidos no DP/2013/1, para reter um conceito que requereria que os lucros ou perdas fossem apresentados como um total ou subtotal na demonstração de lucros ou perdas e OCI. A visão preliminar do IASB é de que a Estrutura Conceitual deve exigir os resultados como um total ou subtotal. Ao discutir se a Estrutura Conceitual deve ou não incluir um conceito para os lucros e perdas, os argumentos a favor e contra a reciclagem também devem ser considerados. Isso é porque, se não houver reciclagem, então os lucros e perdas não serão diferentes na natureza do que os outros totais e subtotais. A visão preliminar do IASB é de que a Estrutura Conceitual deve exigir um total ou subtotal de lucros ou perdas que também resulte, ou possa resultar, na reciclagem de alguns itens de receita ou despesa.

Três abordagens foram propostas no tocante a lucros ou perdas e reciclagem. A primeira abordagem proíbe a reciclagem, adereçando as visões daqueles que pensam que a Estrutura Conceitual deva proibir a reciclagem. Duas abordagens que exploram a visão preliminar do IASB de que a Estrutura Conceitual deva exigir um total ou subtotal de lucros ou perdas que também resulte, ou possa resultar, na reciclagem de alguns itens de receita ou despesa: a) A abordagem 2A: uma abordagem estreita de descrever quais itens podem ser reconhecidos em OCI; e, b) A abordagem 2B: uma abordagem mais ampla de descrever quais itens podem ser reconhecidos em OCI.

A abordagem 1 reflete a visão de que itens de receita e despesa devem ser reconhecidos na declaração de lucros ou perdas e OCI apenas uma vez e não devem, portanto, nunca ser reciclados.

A Abordagem 2A propõe que todos os itens de receita ou despesa deveriam se reconhecidos em lucros e perdas em algum momento. Consequentemente, sob a Abordagem 2A, todos os itens que haviam sido previamente reconhecidos em OCI deveriam ser reclassificados (reciclados) para os lucros ou perdas no(s) período(s) subsequente(s) quando a reclassificação resultar em informação relevante. Em muitos casos isso ocorrerá na realização, liquidação ou imparidade, apesar de que, em alguns casos, a reciclagem pode precisar ocorrer em outro momento. Segue-se que se a reciclagem não resultar em informação relevante em nenhum período subsequente, o item de receita ou despesa não seria elegível para o reconhecimento em $\mathrm{OCI}$, de acordo com a Abordagem 2A.

Alguns possuem a visão de que a Abordagem 2A restringe muito o uso de OCI. Os que possuem essa visão se preocupam que: a) alguns itens atualmente reconhecidos em OCI não seriam elegíveis a ser reconhecidos em OCI sob a Abordagem 2A; e, b) reciclar todos tipos de itens reconhecidos em OCI nem sempre fornecerá informações úteis. Para refletir essas visões, a Abordagem 2B permitiria que mais itens fossem reconhecidos em OCI do que a Abordagem 2A. A Abordagem 2B permite ao IASB uma maior discrição do que a Abordagem 2A ao desenvolver ou revisar Normas específicas para determinar se um item de receita ou despesa deve ser reconhecido em OCI e se esse item deve ser reciclado subsequentemente.

\section{SEÇÃO 9 - OUTRAS QUESTÕES \\ CAPÍTULOS REMANESCENTES DA ESTRUTURA CONCEITUAL 2010}

Como resultado do trabalho conjunto do FASB e IASB, em 2010, foram emitidos dois capítulos da estrutura conceitual: Capitulo 1 - O Objetivo de Relatórios Contábeis de Uso Geral, e, Capitulo 3 Características Qualitativas das Informações Financeiras Úteis. Estes capítulos entraram em vigor assim que foram publicados, e agora formam parte da Conceptual Framework existente.

Em relação ao Capitulo 1, entre outros aspectos, define o objetivo do relatório financeiro para fins gerais, a saber, fornecer informação financeira sobre a entidade que reporta essa informação que sejam úteis a investidores existentes e em potencial, mutuários e outros credores, quando da tomada de decisão ligada ao fornecimento de recursos para a entidade.

No que se refere ao Capitulo 3, dissemina-se as características qualitativas da informação contábil útil. Elas se fragmentam em fundamentais e aprimoráveis. Aquelas, partem do pressuposto que, se a informação financeira é para ser útil, ela deve ser relevante e representar fielmente o que se propõe a apresentar. A utilidade da informação financeira é aprimorada se ela for comparável, verificável, tempestiva e compreensível.

Quando o IASB reiniciou o projeto, em 2012, decidiu não se encarregar de uma reconsideração fundamental destes capítulos, tendo em vista que passaram por um extenso processo, fornecem uma fundamentação sólida para o resto da Estrutura Conceitual e uma reconsideração, não levaria a mudanças significativas.

Porém, alguns expressaram preocupações sobre a decisão do IASB de não reconsiderar estes capítulos, em relação: a) ao tratamento de "gestão"; b) a decisão de substituir a característica fundamental de "confiabilidade" com a de "representação fiel" e quanto à decisão de remover qualquer referência ao conceito de "prudência" da Estrutura Conceitual. 
No tocante à "gestão", ao descrever o objetivo dos relatórios financeiros para fins gerais, o IASB, não usa a palavra "gestão" e, para alguns, isso significa que a Estrutura Conceitual já não trata a informação sobre gestão como parte do que é necessário para atender aos objetivos dos relatórios financeiros.

O IASB não tinha a intenção de remover o conceito de "gestão" do objetivo dos relatórios contábeis, mas, descrever o que significa, ao invés de usar o termo em si, pela dificuldade de traduzir o termo stewardship em outros idiomas.

\section{CONFIABILIDADE VERSUS REPRESENTAÇÃO FIEL}

Em referência à "Confiabilidade", a estrutura conceitual pré-2010, á afirmava, como uma das características qualitativas das informações financeiras úteis. Ela foi substituída, em 2010, pela característica qualitativa de Representação Fiel. Ambas exigem neutralidade, plenitude e isenção de erros e a principal diferença entre os dois conceitos é que o capitulo 3 não se refere a prudência e a substancia sob a forma, pois esta, seria redundância da representação fiel.

No que concerne à "Prudência", o IASB removeu as referências a esse conceito, alegando inconsistência com a neutralidade e, subestimar ativos ou superestimar passivos em um período, leva a superavaliar o desempenho financeiro em períodos posteriores.

\section{MODELO DE NEGÓCIO}

O IASB usou pela primeira vez o termo 'modelo de negócios' na IFRS 9 Financial Instruments, que declarava que a classificação e mensuração de ativos financeiros dependia do modelo de negócios da entidade para administrar esses ativos. Recentemente, o IASB exigiu que entidades de investimento não consolidassem algumas de suas subsidiárias (IFRS 10 Consolidated Financial Statements). Isso é porque as entidades de investimento possuem um modelo de negócios único que torna o relatório de subsidiárias a valor justo mais apropriado do que a consolidação.

O modelo de negócios de uma entidade também afeta segmentos operacionais de acordo com a IFRS 8 Operating Segments. Apesar de algumas IFRSs refletirem a maneira para a qual uma entidade participante conduz as suas atividades de negócios, o IASB não definiu o termo 'modelo de negócios'.

Têm-se argumentado que o conceito de modelo de negócios deveria desempenhar uma função significativa no estabelecimento de normas. Alguns pensam que aplicar o conceito de modelo de negócios ao desenvolver as IFRSs fornece informações relevantes devido ao fato de ela fornecer uma visão de como as atividades de negócios da entidade são administrados. Consequentemente, isso ajuda os usuários das demonstrações financeiras a avaliar os recursos da entidade, reivindicações contra a entidade, e como a administração e o conselho administrativo da entidade têm cumprido com suas obrigações no uso dos recursos da entidade.

O DP/2013/1 não define o conceito de modelo de negócios. Contudo, a visão preliminar do IASB é que as demonstrações financeiras podem se tornar mais relevantes se o IASB considerar, ao desenvolver ou revisar Normas específicas, como uma entidade conduz suas atividades de negócios.

\section{UNIDADE DE CONTA}

Para se reconhecer e mensurar ativos e passivos nas demonstrações financeiras de uma maneira que forneça informações úteis para investidores existentes e potenciais, mutuários e outros credores, é, geralmente, necessário agregar recursos individuais, ou outros direitos, e obrigações. O nível de agregação exigida é, geralmente, referido como a unidade de conta. A título de exemplo, a posse de um ativo físico, tal como uma máquina, inclui vários direitos (o direito de usar o ativo, o direito de vender o ativo, o direito de penhorar o ativo ou quaisquer outros direitos conferidos ao ativo por título legal). Apesar de, em princípio, cada um desses direitos ser capaz de se tornar um ativo separado, combiná-los em uma única unidade de conta e reconhecer um único ativo (a máquina) fornecerá, muitas vezes, a informação mais relevante e compreensível para os usuários das demonstrações financeiras. Em outros casos (por exemplo, quando a máquina foi arrendada), reconhecer (ou desreconhecer) alguns dos direitos separadamente pode fornecer uma representação mais fiel da posição financeira da entidade.

\section{MANUTENÇÃO DE CAPITAL}

Os conceitos de manutenção de capital são importantes, porque, apenas a receita obtida em excesso das quantias necessárias para manter o capital, pode ser considerada como lucro. Dois conceitos são abordados: a) manutenção de capital financeiro e, b) manutenção de capital físico. 
Manutenção de capital financeiro: neste conceito, um lucro é obtido apenas se a quantia financeira (ou dinheiro) dos ativos líquidos no fim do período excederem a quantia financeira (ou dinheiro) de ativos líquidos no início do período, após excluir todas as distribuições para, e contribuições dos proprietários durante o período. A manutenção de capital financeiro pode ser mensurada tanto em unidades monetárias nominais ou em unidades de poder de compra constante.

Manutenção de capital físico: neste conceito, um lucro é obtido apenas se a capacidade produtiva física (ou capacidade de operação) da entidade (ou os recursos ou fundos necessários para alcançar essa capacidade) no fim do período excede a capacidade produtiva física do começo do período, após excluir as distribuições para, e contribuições de proprietários durante o período

A maioria das entidades adota um conceito financeiro de manutenção de capital. Contudo, a Estrutura Conceitual existente não determina um modelo específico de manutenção de capital. A Estrutura Conceitual existente aponta que a administração de uma entidade deve exercitar o julgamento e selecionar o conceito de manutenção de capital que forneça a informação mais útil para os usuários das demonstrações financeiras. 
ANEXO B - PERGUNTAS DO DP/2013/1

\begin{tabular}{|c|c|c|}
\hline \multicolumn{3}{|c|}{ Você concorda com as visões preliminares do IASB? } \\
\hline \multirow[b]{2}{*}{$\begin{array}{l}\text { Seção 1: } \\
\text { Introdução }\end{array}$} & $1 \mathrm{~A}$ & $\begin{array}{l}\text { O propósito primário da Estrutura Conceitual revisada é } \\
\text { auxiliar a IASB a identificar conceitos que irá usar } \\
\text { consistentemente ao desenvolver e revisar IFRSs. }\end{array}$ \\
\hline & 1B & $\begin{array}{l}\text { Em casos raros, a fim de cumprir o objetivo global de } \\
\text { relatórios contábeis, o IASB pode decidir emitir uma } \\
\text { Norma, nova ou revisada, que entra em conflito com algum } \\
\text { aspecto da Estrutura Conceitual. Em tais casos, o IASB } \\
\text { descreverá o distanciamento da Estrutura Conceitual, e as } \\
\text { razões para isso, nas Bases para Conclusões daquela } \\
\text { Norma. }\end{array}$ \\
\hline \multirow{6}{*}{$\begin{array}{c}\text { Seção 2: } \\
\text { Elementos de } \\
\text { Relatórios Financeiros }\end{array}$} & $2 \mathrm{~A}$ & $\begin{array}{l}\text { Um ativo é um recurso econômico presente controlado pela } \\
\text { entidade como resultado de eventos passados. }\end{array}$ \\
\hline & $2 \mathrm{~B}$ & $\begin{array}{l}\text { Um passivo é uma obrigação presente da entidade de } \\
\text { transferir um recurso econômico como um resultado de } \\
\text { eventos passados. }\end{array}$ \\
\hline & $2 \mathrm{C}$ & $\begin{array}{l}\text { Um recurso econômico é um direito, ou outra fonte de } \\
\text { valor, que é capaz de produzir benefícios econômicos. }\end{array}$ \\
\hline & $3 \mathrm{~A}$ & $\begin{array}{l}\text { As definições de ativos e passivos não devem reter a noção } \\
\text { de que uma entrada ou saída é esperada. Um ativo deve ser } \\
\text { capaz de produzir benefícios econômicos. O passivo deve } \\
\text { ser capaz de resultar em uma transferência de recursos } \\
\text { econômicos. }\end{array}$ \\
\hline & $3 \mathrm{~B}$ & $\begin{array}{l}\text { A Estrutura Conceitual não deve definir um limite de } \\
\text { probabilidade para os raros casos em que é incerto se um } \\
\text { ativo ou um passivo existe. Se pudesse haver incerteza } \\
\text { significativa sobre se um determinado tipo de ativo ou } \\
\text { passivo existe, o IASB decidiria como lidar com essa } \\
\text { incerteza quando se desenvolve ou revisa um padrão nesse } \\
\text { tipo de ativo ou passivo. }\end{array}$ \\
\hline & $3 \mathrm{C}$ & $\begin{array}{l}\text { Os critérios de reconhecimento não devem manter a } \\
\text { referência existente à probabilidade. }\end{array}$ \\
\hline \multirow[b]{2}{*}{$\begin{array}{c}\text { Seção 3: } \\
\text { Orientação adicional } \\
\text { de apoio às definições } \\
\text { de ativo e } \\
\text { passivo }\end{array}$} & 5 & $\begin{array}{l}\text { A discussão considera que a possibilidade de se estreitar a } \\
\text { definição de um passivo para incluir apenas obrigaçoses que } \\
\text { são asseguráveis por lei ou outro meio equivalente. Porém, } \\
\text { o IASB, provisoriamente, favorece a retenção das } \\
\text { definições existentes, que englobam ambas as obrigações } \\
\text { legais e construtivas - e a adição de mais orientações para } \\
\text { ajudar a distinção da obrigação construtiva da compulsão } \\
\text { econômica. }\end{array}$ \\
\hline & 6 & $\begin{array}{l}\text { Uma obrigação presente surge de eventos passados. Uma } \\
\text { obrigação pode ser vista como tendo surgida de eventos } \\
\text { passados se a quantia do passivo for ser determinada por } \\
\text { referência aos benefícios recebidos, ou atividades } \\
\text { conduzidas, pela entidade antes do fim do período de } \\
\text { registro. Entretanto, não é claro se tais eventos passados são } \\
\text { suficientes para criar uma obrigação presente se nenhum } \\
\text { requisito de transferência de recursos econômicos } \\
\text { permanecerem condicionais às ações futuras da entidade. } \\
\text { Três visões diferentes sobre as quais o IASB poderia } \\
\text { desenvolver orientações para a Estrutura Conceitual são } \\
\text { dispostas a seguir: } \\
\text { Visão 1: uma obrigação presente deve originar de eventos } \\
\text { passados e ser estritamente incondicional. Uma entidade } \\
\text { não tem uma obrigação presente se pudesse, pelo menos em } \\
\text { teoria, evitar a transferência por meio de suas ações futuras. }\end{array}$ \\
\hline
\end{tabular}




\begin{tabular}{|c|c|c|}
\hline & & $\begin{array}{l}\text { Visão 2: uma obrigação presente deve originar de eventos } \\
\text { passados e ser praticamente incondicional. Uma obrigação é } \\
\text { praticamente incondicional se a entidade não tem } \\
\text { capacidade prática para evitar a transferência por meio de } \\
\text { suas ações futuras. } \\
\text { Visão 3: uma obrigação presente deve originar de eventos } \\
\text { passados, mas pode ser condicional em ações futuras da } \\
\text { entidade. } \\
\text { O IASB tem, provisoriamente, rejeitado a Visão 1. Porém, } \\
\text { ele ainda não chegou a uma visão preliminar em favor da } \\
\text { Visão } 2 \text { ou da Visão 3. Qual dessas visões você apoia? }\end{array}$ \\
\hline \multirow[b]{3}{*}{$\begin{array}{l}\text { Seção 4: } \\
\text { Reconhecimento e } \\
\text { desreconhecimento }\end{array}$} & $8 \mathrm{~A}$ & $\begin{array}{l}\text { Na visão preliminar do IASB, uma entidade deve } \\
\text { reconhecer todos os seus ativos e passivos, a não ser que o } \\
\text { IASB decida, ao desenvolver ou revisar uma Norma } \\
\text { específica, que uma entidade não precisa, ou não deve, } \\
\text { reconhecer um ativo ou passivo por que: } \\
\text { Reconhecer o ativo (ou passivo) forneceria aos usuários das } \\
\text { demonstrações financeiras uma informação que é } \\
\text { irrelevante, ou insuficientemente relevante para justificar o } \\
\text { custo. }\end{array}$ \\
\hline & $8 \mathrm{~B}$ & $\begin{array}{l}\text { Nenhuma mensuração do ativo (ou passivo) resultará em } \\
\text { uma representação fiel tanto do ativo (ou passivo) e das } \\
\text { mudanças no ativo (ou passivo), mesmo se todas as } \\
\text { descrições e explicações necessárias forem divulgadas. }\end{array}$ \\
\hline & 9 & $\begin{array}{l}\mathrm{Na} \text { visão preliminar do IASB, uma entidade deve } \\
\text { desreconhecer um ativo ou passivo quando ele deixar de } \\
\text { atender aos critérios de definição. Esse é a abordagem de } \\
\text { controle. Contudo, se uma entidade retiver um componente } \\
\text { ou passivo, o IASB deve determinar, ao desenvolver ou } \\
\text { revisar uma Norma específica, como a entidade melhor } \\
\text { retrataria as mudanças resultantes da transação. } \\
\text { As abordagens possíveis incluem: } \\
\text { (a) divulgação aprimorada; } \\
\text { (b) apresentar novos direitos ou obrigações retidos em um } \\
\text { item que difere do item que foi usado pelos direitos ou } \\
\text { obrigações originais, para destacar a maior concentração de } \\
\text { risco; ou } \\
\text { (c) continuar a reconhecer o ativo ou passivo original e } \\
\text { tratar os rendimentos recebidos ou pagos pela transação } \\
\text { como um empréstimo recebido ou concedido. } \\
\text { O IASB tem, provisoriamente, rejeitado a Visão } 1 \text {. Porém, } \\
\text { ele ainda não chegou a uma visão preliminar em favor da } \\
\text { Visão } 2 \text { ou da Visão 3. Você concorda? Por que ou por que } \\
\text { não? }\end{array}$ \\
\hline \multirow{3}{*}{$\begin{array}{c}\text { Seção 5: } \\
\text { Definição de } \\
\text { patrimônio líquido e } \\
\text { distinção entre passivos } \\
\text { e instrumentos de } \\
\text { capital }\end{array}$} & $10 \mathrm{~A}$ & $\begin{array}{l}\text { A Estrutura Conceitual deve manter a atual definição de } \\
\text { capital como o interesse residual nos ativos da entidade } \\
\text { após a dedução de todos os seus passivos. }\end{array}$ \\
\hline & $10 \mathrm{~B}$ & 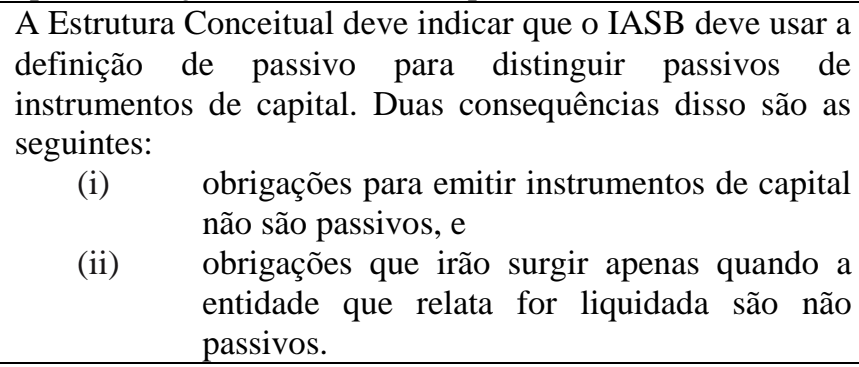 \\
\hline & $10 \mathrm{C}$ & $\begin{array}{l}\text { Uma entidade deve: } \\
\text { (i) atualizar a medida de cada classe de } \\
\text { reivindicação de equivalência patrimonial no } \\
\text { final de cada período de relato. O IASB }\end{array}$ \\
\hline
\end{tabular}




\begin{tabular}{|c|c|c|}
\hline & & $\begin{array}{l}\text { determinaria quando desenvolver ou revisar } \\
\text { Normas em especial se seria uma medida } \\
\text { direta ou uma alocação do capital total. } \\
\text { reconhecer atualizações para essas } \\
\text { mensurações na demonstração de alterações } \\
\text { no capital, como uma transferência de riqueza } \\
\text { entre as classes de reivindicação de } \\
\text { equivalência patrimonial. }\end{array}$ \\
\hline & $10 \mathrm{D}$ & $\begin{array}{l}\text { Se uma entidade não emitiu instrumentos de capital, pode } \\
\text { ser apropriado tratar a mais subordinada classe de } \\
\text { instrumentos como se fosse uma reivindicação de } \\
\text { equivalência patrimonial, com adequada divulgação. } \\
\text { Identificar se é o caso de usar tal abordagem e, em caso } \\
\text { afirmativo, quando, seria uma decisão que o IASB } \\
\text { precisaria fazer quando se desenvolve ou revisa Normas } \\
\text { particulares. }\end{array}$ \\
\hline \multirow{8}{*}{$\begin{array}{c}\text { Seção 6: } \\
\text { Mensuração }\end{array}$} & $11 \mathrm{~A}$ & $\begin{array}{l}\text { O objetivo da mensuração é de contribuir para a } \\
\text { representação fiel de informação relevante sobre: } \\
\text { (i) os recursos da entidade, reivindicações contra } \\
\text { a entidade e mudanças nos recursos e } \\
\text { reivindicações; e } \\
\text { (ii) } \\
\text { o quão eficientemente e eficazmente a } \\
\text { administração e o conselho administrativo da } \\
\text { empresa têm cumprido suas responsabilidades } \\
\text { no uso dos recursos da entidade. }\end{array}$ \\
\hline & $11 \mathrm{~B}$ & $\begin{array}{l}\text { Uma única base de mensuração para todos ativos e passivos } \\
\text { pode não fornecer a informação mais relevante para os } \\
\text { usuários das demonstrações financeiras. }\end{array}$ \\
\hline & $11 \mathrm{C}$ & $\begin{array}{l}\text { Ao selecionar a mensuração a utilizar para um item } \\
\text { específico, o IASB deve considerar qual informação essa } \\
\text { mensuração irá produzir tanto na demonstração de posição } \\
\text { financeira quanto na(s) demonstração(ões) de lucros ou } \\
\text { perdas e OCI. }\end{array}$ \\
\hline & $11 \mathrm{D}$ & $\begin{array}{l}\text { A seleção de uma mensuração: } \\
\text { (i) para um ativo específico deve depender de } \\
\text { como esse ativo contribui para futuros fluxos } \\
\text { de caixa; e } \\
\text { para um passivo específico deve depender de } \\
\text { (ii) } \\
\text { como a entidade irá liquidar ou cumprir esse } \\
\text { passivo. }\end{array}$ \\
\hline & $11 \mathrm{E}$ & $\begin{array}{l}\text { O número de mensurações diferentes usadas deve ser o } \\
\text { menor número necessário para fornecer uma informação } \\
\text { relevante. Mudanças desnecessárias de mensuração devem } \\
\text { ser evitadas e as mudanças necessárias de mensuração } \\
\text { devem ser explicadas. }\end{array}$ \\
\hline & $11 \mathrm{~F}$ & $\begin{array}{l}\text { Os benefícios de uma mensuração específica para os } \\
\text { usuários das demonstrações financeiras precisam ser } \\
\text { suficientes para justificar o seu custo. }\end{array}$ \\
\hline & $12 \mathrm{~A}$ & $\begin{array}{l}\text { As visões preliminares do IASB vistas nas Questões } 11 \text { têm } \\
\text { implicações para a mensuração subsequente de ativos. As } \\
\text { visões preliminares do IASB são de que: } \\
\text { Se ativos contribuem indiretamente para os futuros fluxos } \\
\text { de caixa através do uso ou são usados em combinação a } \\
\text { outros ativos para gerar fluxos de caixa, mensurações } \\
\text { baseadas em custo normalmente fornecem uma informação } \\
\text { que é mais relevante e compreensível do que os preços de } \\
\text { mercado atuais. }\end{array}$ \\
\hline & $12 \mathrm{~B}$ & $\begin{array}{l}\text { Se ativos contribuem para os futuros fluxos de caixa ao } \\
\text { serem vendidos, um preço de saída atual é suscetível a ser } \\
\text { relevante. }\end{array}$ \\
\hline
\end{tabular}




\begin{tabular}{|c|c|c|}
\hline & $12 \mathrm{C}$ & $\begin{array}{l}\text { Se o ativo financeiro possui uma variabilidade } \\
\text { insignificativa nos fluxos de caixa contratuais, e são } \\
\text { mantidos para coleta, uma mensuração baseada em custo } \\
\text { provavelmente fornecerá uma informação relevante. }\end{array}$ \\
\hline & $12 \mathrm{D}$ & $\begin{array}{l}\text { Se uma entidade cobra pelo uso de ativos, a relevância de } \\
\text { uma mensuração específica desses ativos dependerá da } \\
\text { significância do ativo individual para entidade. }\end{array}$ \\
\hline & $13 \mathrm{~A}$ & $\begin{array}{l}\text { São discutidas as implicações que as visões preliminares do } \\
\text { IASB para a mensuração subsequente de passivos. As } \\
\text { visões preliminares do IASB são que: } \\
\text { Mensuração baseadas em fluxo de caixa são suscetíveis a } \\
\text { ser a única mensuração viável para passivos sem termos } \\
\text { apresentados. }\end{array}$ \\
\hline & 13B & 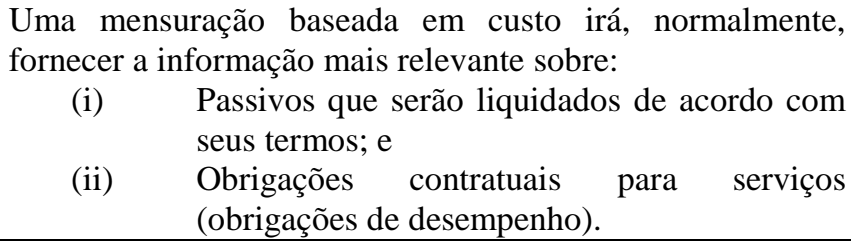 \\
\hline & $13 \mathrm{C}$ & $\begin{array}{l}\text { Preços de mercado atuais provavelmente fornecerão a } \\
\text { informação mais relevante sobre passivos que serão } \\
\text { transferidos. }\end{array}$ \\
\hline & $14 \mathrm{~A}$ & $\begin{array}{l}\text { Afirma que a visão preliminar do IASB que para alguns } \\
\text { ativos financeiros e passivos financeiros (por exemplo, } \\
\text { derivativos), baseando a mensuração na maneira em que } \\
\text { cada ativo contribui para os futuros fluxos de caixa, ou na } \\
\text { maneira em que o passivo é liquidado ou cumprido, pode } \\
\text { não fornecer informação que é útil ao avaliar as } \\
\text { expectativas para futuros fluxos de caixa. Por exemplo, } \\
\text { informação baseada em custo sobre ativos financeiros que } \\
\text { são mantidos para coleta ou passivos financeiros que são } \\
\text { liquidados de acordo com seus termos podem não fornecer } \\
\text { informação que é útil ao avaliar as perspectivas para futuros } \\
\text { fluxos de caixas: } \\
\text { Se o fluxo de caixa definitivo não está proximamente ligado } \\
\text { ao custo original. }\end{array}$ \\
\hline & $14 \mathrm{~B}$ & $\begin{array}{l}\text { Se, devido à variabilidade significativa de fluxos de caixa } \\
\text { contratuais, as técnicas de mensuração baseadas em custo } \\
\text { podem não funcionar porque elas seriam incapazes de } \\
\text { simplesmente alocar pagamentos de juros sobre a vida de } \\
\text { tal ativo ou passivo financeiro. }\end{array}$ \\
\hline & $14 \mathrm{C}$ & $\begin{array}{l}\text { Se mudanças nos fatores de mercado têm um efeito } \\
\text { desproporcional no valor do ativo ou do passivo (i.e. o ativo } \\
\text { ou passivo é altamente alavancado). }\end{array}$ \\
\hline \multirow[t]{2}{*}{$\begin{array}{l}\text { Seção 7: } \\
\text { Apresentação e } \\
\text { divulgação }\end{array}$} & $16 \mathrm{~A}$ & $\begin{array}{l}\text { Você concorda com as visões preliminares sobre o escopo e } \\
\text { o conteúdo da orientação que deveria ser incluída na } \\
\text { Estrutura Conceitual sobre: } \\
\text { (a) apresentação nas demonstrações financeiras primárias, } \\
\text { incluindo: } \\
\text { (i) o que são as demonstrações financeiras primárias; } \\
\text { (ii) o objetivo das demonstrações financeiras primárias } \\
\text { (iii) classificação e agregação; } \\
\text { (iv) compensação; e } \\
\text { (v) a relação entre as demonstrações financeiras primárias. }\end{array}$ \\
\hline & $16 \mathrm{~B}$ & $\begin{array}{l}\text { (b) divulgações nas notas às demonstrações financeiras, } \\
\text { incluindo: } \\
\text { (i) o objetivo das notas às demonstrações financeiras; e } \\
\text { (ii) o escopo das notas às demonstrações financeiras, } \\
\text { incluindo os tipos de informação e divulgações que são } \\
\text { relevantes para atender o objetivo das notas às }\end{array}$ \\
\hline
\end{tabular}




\begin{tabular}{|c|c|c|}
\hline & & $\begin{array}{l}\text { demonstrações financeiras, informação prospectiva e } \\
\text { informaçâo comparativa. }\end{array}$ \\
\hline & 17 & $\begin{array}{l}\text { O conceito de materialidade não é descrito claramente na } \\
\text { Estrutura Conceitual existente. Consequentemente, o IASB } \\
\text { não propõe modificar, ou adicionar, as orientações sobre } \\
\text { materialidade na Estrutura Conceitual. Contudo, o IASB } \\
\text { está considerando desenvolver orientações adicionais ou } \\
\text { material educacional acerca da materialidade por fora do } \\
\text { projeto da Estrutura Conceitual. Você concorda com essa } \\
\text { abordagem? Por que ou por que não? }\end{array}$ \\
\hline & 18 & $\begin{array}{l}\text { Você concorda que os princípios de comunicação devem } \\
\text { ser parte da Estrutura Conceitual? Por que ou por que não? } \\
\text { Se você concorda que eles devem ser incluídos, você } \\
\text { concorda com os princípios de comunicação propostos? } \\
\text { Porque ou por que não? }\end{array}$ \\
\hline & 19 & $\begin{array}{l}\text { A visão preliminar do IASB é que a Estrutura Conceitual } \\
\text { deveria exigir um total ou subtotal para lucros ou perdas. } \\
\text { Você concorda? Por que ou por que não? } \\
\text { Se você não concorda, você acha que o IASB deveria ainda } \\
\text { ser capaz de exigir um total ou subtotal de lucros ou perdas } \\
\text { ao desenvolver ou revistar Normas específicas? }\end{array}$ \\
\hline $\begin{array}{l}\text { Seção 8: } \\
\text { Apresentação na } \\
\text { demonstração de } \\
\text { resultados abrangentes } \\
\text { - lucros ou perdas e } \\
\text { outros resultados } \\
\text { abrangentes }\end{array}$ & 20 & $\begin{array}{l}\text { A visão preliminar do IASB de que a Estrutura Conceitual } \\
\text { deveria permitir ou exigir pelo menos alguns dos itens de } \\
\text { receita e despesa previamente reconhecidos em OCI a } \\
\text { serem reconhecidos subsequentemente em lucros ou perdas, } \\
\text { i.e. reciclados. } \\
\text { Você concorda? Por que ou por que não? Se você concorda, } \\
\text { você acha que todos os itens de receita e despesa } \\
\text { apresentados em OCI deveriam ser reciclados em lucros ou } \\
\text { perdas? Por que ou por que não? } \\
\text { Se você não concorda, como iria abordar os fluxos de caixa } \\
\text { da contabilidade de hedge (hedge accounting)? }\end{array}$ \\
\hline & 21 & $\begin{array}{l}\text { Duas abordagens são exploradas que descrevem quais itens } \\
\text { poderiam se incluídos em OCI: uma abordagem minuciosa } \\
\text { (Abordagem 2A) e uma abordagem ampla (Abordagem } \\
\text { 2B). } \\
\text { Qual dessas abordagens você apoia, e por quê? Se você } \\
\text { apoia uma abordagem diferente, por favor, descreva essa } \\
\text { abordagem e explique por que você acredita que é } \\
\text { preferível às abordagens descritas neste Documento de } \\
\text { Discussão. }\end{array}$ \\
\hline $\begin{array}{c}\text { Seção 9: } \\
\text { Outras questões }\end{array}$ & 22 & $\begin{array}{l}\text { São discutidos os capítulos da Estrutura Conceitual } \\
\text { existente (Capítulos } 1 \text { e } 3 \text { ) que foram publicados em } 2010 \text { e } \\
\text { como esses capítulos tratam os conceitos de gestão, } \\
\text { confiabilidade e prudência. O IASB fará mudanças a esses } \\
\text { capítulos se o trabalho no resto da Estrutura Conceitual } \\
\text { destacar áreas que precisam de esclarecimento e mudanças. } \\
\text { Contudo, o IASB não planeja reconsiderar } \\
\text { fundamentalmente o conteúdo desses capítulos. } \\
\text { Você concorda com essa abordagem? Por favor, explique } \\
\text { seus motivos. } \\
\text { Se você acredita que o IASB poderia considerar mudanças } \\
\text { a esses capítulos (incluindo como esses capítulos tratam os } \\
\text { conceitos de gestão, confiabilidade e prudência), por favor, } \\
\text { explique essas mudanças e os motivos para elas, e, por } \\
\text { favor, explique o mais precisamente possível como elas } \\
\text { iriam afetar o restante da Estrutura Conceitual. }\end{array}$ \\
\hline & 23 & $\begin{array}{l}\text { Este Documento de Discussão não define o conceito de } \\
\text { modelo de negócios. Contudo, a visão preliminar do IASB } \\
\text { é de que demonstrações financeiras podem se tornar mais }\end{array}$ \\
\hline
\end{tabular}




\begin{tabular}{|l|l|l|}
\hline \multirow{5}{*}{} & $\begin{array}{l}\text { relevantes se o IASB considerar, ao desenvolver ou revisar } \\
\text { Normas específicas, como uma entidade conduz suas } \\
\text { atividades de negócios. } \\
\text { Você acha que o IASB deveria usar o conceito de modelo } \\
\text { de negócios ao desenvolver e revisar Normas específicas? } \\
\text { Por que ou por que não? Se você concorda, em quais áreas } \\
\text { você acha que o conceito de modelo de negócios seria útil? } \\
\text { O IASB deveria definir o 'modelo de negócios'? Por que ou } \\
\text { por que não? Se você acha que 'modelo de negócios' deva } \\
\text { ser definido, como você o definiria? }\end{array}$ \\
\hline \multirow{5}{*}{24} & $\begin{array}{l}\text { A visão preliminar do IASB é que a unidade de conta será } \\
\text { decidida normalmente enquanto o IASB desenvolve o } \\
\text { revisa normas específicas e que, ao escolher a unidade de } \\
\text { conta o IASB deveria considerar as características } \\
\text { qualitativas das informações financeiras úteis. } \\
\text { Você concorda? Por que ou por que não? }\end{array}$ \\
\hline \multirow{5}{*}{26} & $\begin{array}{l}\text { O IASB planeja incluir as descrições existentes e a } \\
\text { discussão sobre conceitos de manutenção de capital na } \\
\text { Estrutura Conceitual revisada praticamente inalterada até } \\
\text { que o momento em que uma Norma nova ou revisada sobre } \\
\text { contabilidade em alta inflação indique uma necessidade de } \\
\text { mudaça. } \\
\text { Você concorda? Por que ou por que não? }\end{array}$ \\
\hline
\end{tabular}

Fonte: Traduzido de IASB (2013) 


\section{ANEXO C - RESUMO DAS DECISÕES PROVISÓRIAS}

Agenda IASB, ref. 10A

\section{Projeto: Estrutura Conceitual}

\section{Tópico: Resumo das decisões provisórias}

Este documento foi preparado pela equipe da Fundação IFRS para discussão em reunião pública do IASB e não representam as opiniões do IASB ou de qualquer membro individual. Comentários sobre a aplicação das IFRS não pretendem estabelecer aplicação aceitável ou inaceitável de IFRS. As decisões técnicas são feitas em público e relatado na atualização do IASB.

\begin{tabular}{|c|c|}
\hline Propostas do Discussion Paper & Decisões provisórias para o Exposure Draft \\
\hline $\begin{array}{l}\text { O IASB decidiu construir na } \begin{array}{c}\text { Conceptual } \\
\text { atualização, }\end{array} \\
\text { Framework existente - } \\
\text { aperfeiçoamento e preenchimento de lacunas em } \\
\text { vez fundamentalmente repensar todos os aspectos } \\
\text { da Estrutura Conceitual. } \\
\text { A Estrutura Conceitual trata dos relatórios } \\
\text { financeiros. Este documento de discussão centra-se } \\
\text { em demonstrações financeiras, que são uma forma } \\
\text { de relatório financeiro. Para completar a Estrutura } \\
\text { Conceitual revista em tempo hábil, o IASB não } \\
\text { pretende abordar neste projeto outras formas de } \\
\text { relatórios financeiros, como o comentário da } \\
\text { administração, relatórios trimestrais, comunicados } \\
\text { de imprensa e material suplementar fornecido com } \\
\text { analistas. } \\
\text { O IASB pretende finalizar um quadro conceptual } \\
\text { revista em } 2015 \text {. }\end{array}$ & $\begin{array}{l}\text { Em } 24 \text { de abril de 2014, o IASB aprovou } \\
\text { provisoriamente a estratégia proposta para } \\
\text { redeliberação da Estrutura Conceitual. Para a } \\
\text { maioria das áreas as sugestões do documento de } \\
\text { discussão serão desenvolvidas à luz das respostas } \\
\text { ao documento de discussão. } \\
\text { As áreas de passivo e patrimônio líquido, } \\
\text { mensuração e lucro ou prejuízo e outros resultados } \\
\text { abrangentes (OCI), foram discutidos } \\
\text { separadamente. } \\
\text { O IASB também aprovou provisoriamente o } \\
\text { calendário das redeliberações. O IASB pretende } \\
\text { emitir um projeto de exposição da Estrutura } \\
\text { Conceitual revista até ao final de } 2014 \text {. }\end{array}$ \\
\hline \multicolumn{2}{|c|}{$\begin{array}{c}\text { Seção 1 } \\
\text { Introdução }\end{array}$} \\
\hline $\begin{array}{l}\text { Opiniões preliminares do IASB sobre a finalidade } \\
\text { e status da Estrutura Conceitual são as seguintes: } \\
\text { (a) o objetivo principal da Estrutura Conceitual } \\
\text { revista é ajudar o IASB, identificando conceitos } \\
\text { que o IASB irá usar de forma consistente no } \\
\text { desenvolvimento e revisão IFRS. } \\
\text { (b) a Estrutura Conceitual também pode ajudar } \\
\text { outras partes, além do IASB para: } \\
\text { (i) compreender e interpretar as IFRS em vigor; e } \\
\text { (ii) desenvolver políticas contábeis quando } \\
\text { nenhuma Norma ou Interpretação se aplicar } \\
\text { especificamente a uma transação ou evento } \\
\text { particular. } \\
\text { (c) a Estrutura Conceitual não é uma Norma ou } \\
\text { Interpretação e não substitui qualquer norma ou } \\
\text { interpretação específica. } \\
\text { (d) em casos raros, a fim de cumprir o objetivo } \\
\text { global dos relatórios financeiros, o IASB pode }\end{array}$ & $\begin{array}{l}\text { Em } 24 \text { de abril de 2014, o IASB discutiu a } \\
\text { finalidade e o status da Estrutura Conceitual. O } \\
\text { IASB decidiu provisoriamente que: } \\
\text { (a) O objetivo da Estrutura Conceitual deve ser } \\
\text { identificar os conceitos que: } \\
\text { (i) auxiliam o IASB para desenvolver e revisar as } \\
\text { normas; } \\
\text { (ii) ajudar os preparadores para desenvolver as } \\
\text { políticas contábeis quando nenhuma Norma aplica- } \\
\text { se a uma transação particular, evento ou condição; } \\
\text { (iii) ajudar todas as partes para compreender e } \\
\text { interpretar as normas. } \\
\text { (b) a situação existente da Estrutura Conceitual } \\
\text { deve ser mantida - ou seja, a Estrutura Conceitual } \\
\text { não é uma Norma e não substitui as exigências das } \\
\text { Normas específicas. } \\
\text { (c) os preparadores não devem ser impedidos de } \\
\text { aplicar determinados aspectos da Estrutura }\end{array}$ \\
\hline
\end{tabular}


decidir emitir uma norma nova ou revista que esteja em conflito com um aspecto da Estrutura Conceitual. Nesses casos, o IASB descreveria a partida desse aspecto do quadro conceptual, e as razões para isso, nas bases para conclusões sobre esta Norma.
Conceitual.

(d) em um número limitado de casos, o IASB pode afastar-se dos aspectos da Estrutura Conceitual. Se o IASB fizer isso, irá explicar o desvio nas bases para conclusões sobre a Norma em questão.

\begin{tabular}{|c|}
\hline $\begin{array}{r}\text { Seçãa } \\
\text { Elementos dos Rela }\end{array}$ \\
\hline Definições de A \\
\hline $\begin{array}{l}\text { O IASB acredita que as definições de ativos e } \\
\text { passivos poderiam ser esclarecidas. Elas contêm } \\
\text { referências a entradas ou saídas de benefícios } \\
\text { econômicos esperados. Alguns interpretaram estas } \\
\text { referências como o reconhecimento de que o ativo } \\
\text { ou o passivo é a entrada ou saída final de recursos, } \\
\text { ao invés do recurso ou obrigação subjacente. Para } \\
\text { evitar mal-entendidos, o parecer preliminar do } \\
\text { IASB é que ele deve alterar as definições para } \\
\text { confirmar de forma mais explícita que: }\end{array}$ \\
\hline
\end{tabular}

(a) um ativo (ou passivo) é o recurso subjacente (ou obrigação), ao invés da entrada final (ou saída) de benefícios econômicos; e

(b) um ativo (ou passivo) deve ser capaz de gerar entradas (ou saídas) de benefícios econômicos. Essas entradas (ou saídas) não precisam ser certas. O IASB propõe as seguintes definições:

(a) um ativo é um recurso econômico presente controlado pela entidade como resultado de eventos passados.

(b) Um passivo é uma obrigação presente da entidade de transferir um recurso econômico, como resultado de eventos passados.

(c) um recurso económico é um direito, ou outra fonte de valor, que é capaz de produzir benefícios econômicos.
Seção 2 


\begin{tabular}{|c|c|}
\hline & $\begin{array}{l}\text { passivo. A orientação de apoio deve esclarecer que } \\
\text { a obrigação deve conter um recurso existente, que } \\
\text { é capaz de exigir que a entidade transfira um } \\
\text { recurso econômico. } \\
\text { Para refletir as decisões acima, os projetos de } \\
\text { definições são as seguintes: } \\
\text { (a) um ativo é um recurso econômico presente, } \\
\text { controlado pela entidade como resultado de } \\
\text { eventos passados. } \\
\text { (b) Um passivo é uma obrigação presente da } \\
\text { entidade de transferir um recurso econômico, } \\
\text { como resultado de eventos passados. } \\
\text { (c) um recurso económico é um direito que é capaz } \\
\text { de produzir benefícios econômicos. }\end{array}$ \\
\hline \multicolumn{2}{|c|}{ Outros Elementos } \\
\hline $\begin{array}{l}\text { Esta seção discute brevemente como definir os } \\
\text { principais blocos de construção (elementos) para } \\
\text { as demonstrações dos lucros ou prejuízos e outros } \\
\text { resultados abrangentes (receitas e despesas), a } \\
\text { demonstração dos fluxos de caixa (recebimentos e } \\
\text { pagamentos em dinheiro) e a demonstração das } \\
\text { mutações do patrimônio líquido (contribuições } \\
\text { para o capital próprio, distribuições de capital } \\
\text { próprio, e as transferências entre as classes de } \\
\text { equivalência patrimonial). }\end{array}$ & $\begin{array}{l}\text { Em } 21 \text { de Maio de 2014, o IASB decidiu } \\
\text { provisoriamente que a Estrutura Conceitual deve } \\
\text { continuar a definir receitas e despesas em função } \\
\text { de alterações nos ativos e passivos. } \\
\text { O IASB observou que a abordagem para definir as } \\
\text { receitas e despesas não predetermina quais os } \\
\text { ativos e passivos devem ser reconhecidos, como } \\
\text { devem ser mensurados e como receitas e despesas } \\
\text { devem ser agregadas, analisadas e apresentadas. } \\
\text { Para as decisões sobre essas questões, o IASB } \\
\text { continuaria a considerar a natureza da informação } \\
\text { que resultaria na demonstração da posição } \\
\text { financeira, e também na demonstração dos lucros } \\
\text { ou prejuízos e outros resultados abrangentes. } \\
\text { Em 24 de julho de 2014, o IASB decidiu } \\
\text { provisoriamente que a Estrutura Conceitual não } \\
\text { deve definir elementos para a demonstração das } \\
\text { mutações do patrimônio líquido e da demonstração } \\
\text { dos fluxos de caixa. Assim, os únicos elementos } \\
\text { que continuam a serem ativos passivos e } \\
\text { patrimônio líquido, e as receitas e despesas. }\end{array}$ \\
\hline \multicolumn{2}{|c|}{$\begin{array}{c}\text { Seção } 3 \\
\text { Orientações adicionais de apoio às definições de Ativo e Passivo }\end{array}$} \\
\hline $\begin{array}{l}\text { A Seção } 3 \text { considera as áreas em que o IASB } \\
\text { poderia adicionar mais orientações para a Estrutura } \\
\text { Conceitual para apoiar as definições revistas de um } \\
\text { ativo e um passivo. } \\
\text { Seção } 3 \text { sugere a seguinte: } \\
\text { (a) Apoiar a definição de um ativo, a orientação } \\
\text { deve ser fornecidas em: } \\
\text { (i) o significado de recurso econômico; e, } \\
\text { (ii) o significado de controle. } \\
\text { (b) Apoiar a definição de um passivo, a orientação } \\
\text { deve ser fornecidas em: } \\
\text { (i) o significado de transferir um recurso } \\
\text { econômico; } \\
\text { (ii) obrigações construtivas; e, } \\
\text { (iii) o significado de obrigação presente. } \\
\text { (c) apoiar ambas as definições, as orientações } \\
\text { devem ser fornecidas em: } \\
\text { (i) relatar a substância dos direitos contratuais e } \\
\text { obrigações contratuais; e, } \\
\text { (ii) contratos executórios. } \\
\text { Para obrigações construtivas, o parecer preliminar } \\
\text { da IASB é que a atual definição de um passivo - }\end{array}$ & $\begin{array}{l}\text { Em } 19 \text { de junho de 2014, o IASB decidiu } \\
\text { provisoriamente que a Estrutura Conceitual deve } \\
\text { incluir: } \\
\text { (a) orientação sobre os recursos económicos, com } \\
\text { base no ponto } 3.5 \text { do documento de discussão, mas } \\
\text { evitar detalhes excessivos; e, } \\
\text { (b) orientação sobre os benefícios económicos, em } \\
\text { geral, coerentes com a orientação no ponto } 3.6 \text { do } \\
\text { documento de discussão, e parágrafo } 35 \text { da IFRS } \\
15 \text { Revenue from Contracts with Customers. } \\
\text { O IASB também decidiu provisoriamente que a } \\
\text { finalidade da depreciação e amortização é } \\
\text { descrever o consumo do recurso económico que } \\
\text { constitui uma mais-valia. } \\
\text { Além disso, em } 19 \text { de junho de } 2014 \text {, o IASB } \\
\text { decidiu provisoriamente que a Estrutura } \\
\text { Conceitual deve incluir conceitos que explicam a } \\
\text { natureza dos ativos e passivos em contratos } \\
\text { executórios. Deve afirmar que: } \\
\text { (a) um contrato executório executável contém um } \\
\text { direito e uma obrigação de trocar recursos } \\
\text { econômicos (ou a pagar ou receber a diferença de }\end{array}$ \\
\hline
\end{tabular}


que engloba tanto obrigações legais e construtivas - deve ser mantido e mais orientação deve ser adicionado para ajudar a distinguir obrigações construtivas de compulsão econômica.

A discussão sobre o significado da obrigação presente observa que ela decorrente de acontecimentos passados. Uma obrigação pode ser visto como tendo surgido de eventos passados, se o valor do passivo será determinado por referência a benefícios recebidos, ou atividades realizadas pela entidade antes do final do período de relatório. No entanto, não está claro se esses eventos passados são suficientes para criar uma obrigação presente, se a exigência de transferência de um recurso econômico continuar a depender de futuras ações da entidade. A discussão identifica três diferentes pontos de vista que o IASB poderia usar como ponto de partida na elaboração de orientações para o Quadro Conceptual:

(a) Visão 1: uma obrigação presente, deve ter surgido de eventos passados e ser estritamente incondicional. Uma entidade não tem uma obrigação presente, se pudesse, ao menos em tese, evitar a transferência por meio de suas ações futuras.

(b) Visão 2: uma obrigação presente, deve ter surgido de eventos passados e ser praticamente incondicional. Uma obrigação é praticamente incondicional se a entidade não tem a capacidade prática para evitar a transferência por meio de suas ações futuras.

(c) Visão 3: uma obrigação presente, deve ter surgido de eventos passados, mas pode ser condicionada a ações futuras da entidade.

O IASB provisoriamente tem rejeitado a Visão 1. No entanto, ele não chegou a uma conclusão preliminar a favor da Visão 2 ou 3. valores entre dois recursos econômicos, se o contrato será liquidado). A obrigação certa e combinada constituiria um único ativo ou passivo; e,

(b) se a entidade entra em um contrato a termo para comprar um recurso em uma data futura, o ativo da entidade é normalmente o seu direito de comprar o recurso subjacente, e não o próprio recurso subjacente. No entanto, em algumas circunstâncias, os termos de um contrato a termo para comprar um recurso pode dar o controle ao comprador desse recurso. Em tais circunstâncias, o comprador deve identificar tanto um ativo (o recurso subjacente que já controla) e um passivo (a obrigação de pagamento para o recurso). Nestas circunstâncias, o contrato não é executório: o vendedor tem realizado substancialmente as suas obrigações.

O IASB tem provisoriamente decidido que a Estrutura Conceitual não deve abordar a mensuração dos ativos e passivos de contratos executórios. Em vez disso, o IASB deve aplicar os conceitos de mensurações gerais na Estrutura Conceitual ao especificar requisitos para determinados tipos de contrato executório dentro do padrão aplicável.

O IASB observou que muitas normas existentes se aplicam implicitamente as mesmas bases de mensuração para ativos ou passivos como eles especificam para os ativos ou passivos que surgem quando uma das partes executa posteriormente as suas obrigações contratuais executórias. O resultado é que muitos ativos e passivos de contratos executórios são mensurados a zero (e, portanto, não são reconhecidos), a menos que o contrato seja oneroso.

Em 24 de julho de 2014, o IASB discutiu o significado de obrigação presente e decidiu provisoriamente que uma entidade tem uma obrigação presente de transferir um recurso econômico, como resultado de eventos passados se ambos:

(a) a entidade não tem capacidade prática para evitar a transferência; e,

(b) o montante da transferência é determinado por referência aos benefícios que a entidade recebeu, ou atividades que tenha realizado, no passado.

O IASB observou que terá de considerar que o significado de "nenhuma habilidade prática" para as operações no âmbito de determinadas normas que se desenvolve ou altera. No entanto, a Estrutura Conceitual deve esclarecer que o fato de que uma entidade tem a intenção de fazer uma transferência ou de que a transferência é provável não é suficiente para concluir que a entidade não tem capacidade prática para evitar a transferência. O IASB provisoriamente decidiu que a Estrutura Conceitual deve incluir a seguinte orientação geral: 


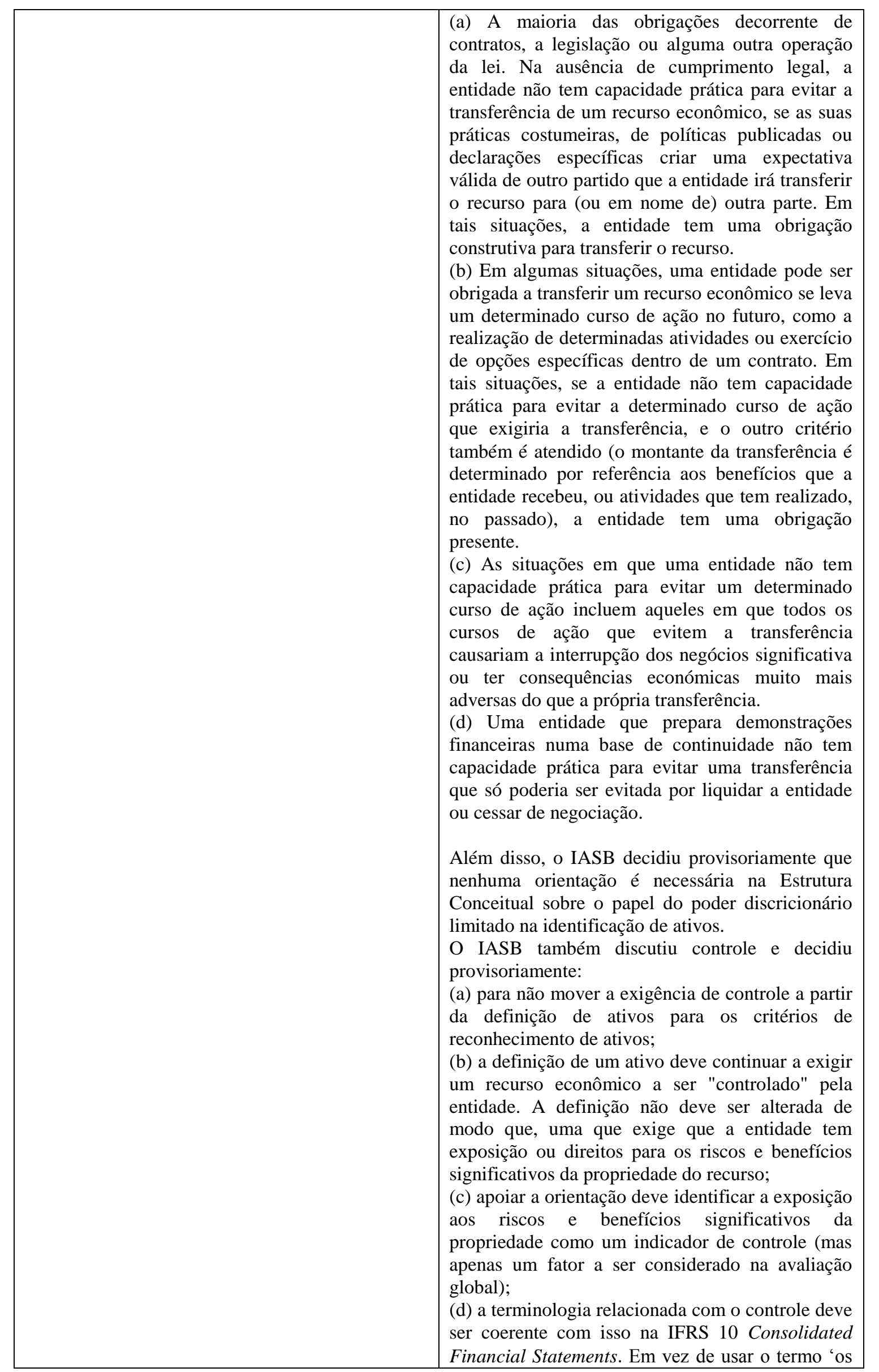




\begin{tabular}{|c|c|}
\hline & $\begin{array}{l}\text { riscos e benefícios de propriedade' a Estrutura } \\
\text { Conceitual deve usar texto que explica o } \\
\text { significado desse termo, ou seja, de exposição, ou } \\
\text { direitos, para variações de benefícios; e, } \\
\text { (e) a Estrutura Conceitual deve indicar que uma } \\
\text { entidade controla um recurso econômico se ele tem } \\
\text { a capacidade presente de dirigir o uso do recurso } \\
\text { económico e obter os benefícios económicos que } \\
\text { daí decorre. } \\
\text { Além disso, o IASB decidiu provisoriamente que a } \\
\text { Estrutura Conceitual deve incluir orientação de } \\
\text { apoio sobre o significado de controle, com base na } \\
\text { orientação sugerida nos parágrafos } 3,26-3,32 \text { do } \\
\text { documento de discussão, mas: } \\
\text { (a) esclarecimento adicional que um componente } \\
\text { de controle é a capacidade de impedir que outras } \\
\text { partes direcionem o uso e obtenham os benefícios } \\
\text { do recurso econômico; e, } \\
\text { (b) exclusão de alguns dos exemplos que foram } \\
\text { incluídos no documento de discussão. }\end{array}$ \\
\hline \multicolumn{2}{|c|}{$\begin{array}{c}\text { Seção } 4 \\
\text { Reconhecimento e Desreconhecimento } \\
\end{array}$} \\
\hline $\begin{array}{l}\text { A Seção } 4 \text { discute: } \\
\text { (a) o reconhecimento: quando deve a } \\
\text { demonstração financeira de uma entidade relatar } \\
\text { um recurso econômico como um ativo ou de uma } \\
\text { obrigação como passivo? } \\
\text { (b) desreconhecimento: quando uma entidade deve } \\
\text { remover um ativo ou um passivo de sua } \\
\text { demonstração da posição financeira? } \\
\text { A posiçâo preliminar da IASB sobre o } \\
\text { reconhecimento é que uma entidade deve } \\
\text { reconhecer todos os seus ativos e passivos, a } \\
\text { menos que o IASB decide quando desenvolver ou } \\
\text { revisar uma determinada Norma que uma entidade } \\
\text { não precisa, ou não deve, reconhecer um ativo ou } \\
\text { um passivo porque: } \\
\text { (a) o reconhecimento do ativo (ou passivo) iria } \\
\text { fornecer aos usuários das demonstrações } \\
\text { financeiras informação que não é relevante ou não } \\
\text { é suficientemente relevante para justificar o custo; } \\
\text { ou, } \\
\text { (b) nenhuma mensuração do ativo (ou passivo) } \\
\text { resultaria em uma representação fiel do ativo (ou } \\
\text { passivo) e as mudanças no ativo (ou passivo), } \\
\text { mesmo se todas as descrições e explicações } \\
\text { necessárias são divulgadas. } \\
\text { A Estrutura Conceitual existente não aborda o } \\
\text { desreconhecimento. A posição preliminar da IASB } \\
\text { é que uma entidade deve desreconhecer um ativo } \\
\text { ou um passivo quando se deixa de cumprir os } \\
\text { critérios de reconhecimento. No entanto, para os } \\
\text { casos em que uma entidade mantém um } \\
\text { componente de um ativo ou um passivo, o IASB } \\
\text { deve determinar no desenvolvimento ou revisão de } \\
\text { Normas particulares, como a entidade deve melhor } \\
\text { retratar as mudanças que resultaram da transação. } \\
\text { As abordagens possíveis incluem: } \\
\text { (a) A divulgação apropriada; } \\
\text { (b) apresentação de quaisquer direitos ou }\end{array}$ & $\begin{array}{l}\text { Em } 21 \text { de Maio de 2014, o IASB decidiu } \\
\text { provisoriamente que a Estrutura Conceitual não } \\
\text { deve estabelecer critérios que regem o } \\
\text { reconhecimento de um ativo ou passivo em todas } \\
\text { as circunstâncias. A estrutura conceitual deve } \\
\text { como alternativa, descrever fatores a considerar ao } \\
\text { decidir se reconhece um ativo ou passivo. Esses } \\
\text { fatores incluem se a informação resultante seria } \\
\text { relevante e fornece uma representação fiel, e os } \\
\text { custos da prestação de informações em relação aos } \\
\text { benefícios. Informações podem não ser relevantes } \\
\text { se, por exemplo, é incerto se o ativo ou passivo } \\
\text { existe, se é pouco provável que os fluxos futuros } \\
\text { de benefícios econômicos irão ocorrer ou se há } \\
\text { uma incerteza muito significativa de mensuração } \\
\text { associada ao item. A agenda Paper } 10 B \text { contém } \\
\text { um projeto inicial que descreve esses fatores. O } \\
\text { IASB dirigiu a equipe a desenvolver essa } \\
\text { descrição, à luz da discussão do IASB. } \\
\text { O IASB observou que o seu objetivo na revisão } \\
\text { das definições de um ativo e de um passivo e os } \\
\text { critérios de reconhecimento foram proporcionar } \\
\text { mais clareza, para não ampliar ou limitar a gama } \\
\text { de reconhecimento de ativos e passivos. } \\
\text { Em } 24 \text { de julho de 2014, o IASB decidiu } \\
\text { provisoriamente que a Estrutura Conceitual deve } \\
\text { descrever as abordagens disponíveis, e discutir que } \\
\text { fatores a considerar, ao decidir no nível de } \\
\text { Padrões: } \\
\text { (a) a melhor forma de retratar as mudanças que } \\
\text { resultam de uma transação em que uma entidade } \\
\text { retém apenas um componente de um ativo ou um } \\
\text { passivo, por meio de: } \\
\text { (i) desreconhecimento total - i.e. desreconhece o } \\
\text { ativo original (ou passivo) totalmente e reconhece } \\
\text { qualquer direito (ou obrigação) retido como um } \\
\text { novo ativo (ou passivo); } \\
\text { (ii) desreconhecimento parcial - ou seja, continuar }\end{array}$ \\
\hline
\end{tabular}




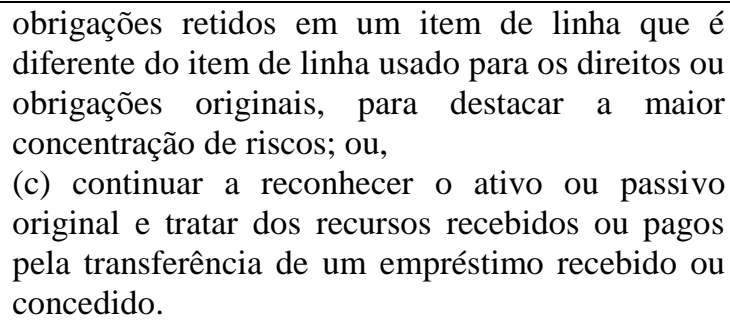
diferente do item de linha usado para os direitos ou obrigações originais, para destacar a maior concentração de riscos; ou,

(c) continuar a reconhecer o ativo ou passivo original e tratar dos recursos recebidos ou pagos pela transferência de um empréstimo recebido ou concedido.

a reconhecer o componente do ativo original (ou passivo), que é mantido e desreconhece o componente que não é mantido; ou,

(iii) continua a reconhecer - isto é, continuar a reconhecer o ativo original (ou passivo) e tratar os recursos recebidos ou pagos para a transferência de um empréstimo recebido (ou concedido); e,

(b) como contabilizar as modificações de contratos.

\section{Seção 5}

Definição de Patrimônio Líquido e Distinção entre Passivo e Instrumento de Capital

Seção 5 discute a definição de Patrimônio Líquido, a mensuração e a apresentação de diferentes classes de Patrimônio Líquido e como distinguir Passivos de Instrumentos de Capital. Opiniões preliminares do IASB são:

(a) A Estrutura Conceitual deve manter a atual definição de Patrimônio Líquido como o interesse residual nos Ativos da entidade após a dedução de todos os seus Passivos.

(b) A Estrutura Conceitual deve declarar que o IASB deve utilizar a definição de um Passivo para distinguir Passivos de Instrumentos de Capital. Duas consequências disso são:

(i) a obrigação de emitir Instrumentos de Capital não são passivos; e,

(ii) obrigações que irão surgir apenas quando a entidade que relata é liquidada, não são Passivos.

(c) uma entidade deve:

(i) atualizar a medida de cada classe de reivindicação de Patrimônio no final de cada período de relatório. O IASB iria determinar quando desenvolver ou revisar determinadas Normas se esta medida seria uma medida direta ou uma alocação do capital total.

(ii) reconhecer atualizações para essas medições na demonstração das mutações do patrimônio, como uma transferência de riqueza entre as classes de reivindicações de Patrimônio.

(d) se a entidade não emitiu instrumentos de capital, pode ser apropriado tratar a classe mais subordinada de instrumentos como se fosse uma reivindicação de Patrimônio, com a divulgação adequada. Identificar se é o caso de usar tal abordagem e, em caso afirmativo, quando, seria uma decisão que o IASB precisaria fazer quando se desenvolve ou revisa Normas particulares.

\section{Seção 6}

Mensuração

As visões preliminares do IASB são que:
(a) o objetivo da mensuração é de contribuir para a representação fiel de informação relevante sobre:

(i) os recursos da entidade, reivindicações contra a entidade e mudanças nos recursos e reivindicações; e

(ii) o quão eficientemente e eficazmente a administração e o conselho administrativo da empresa têm cumprido suas responsabilidades no uso dos recursos da entidade.

(b) uma única base de mensuração para todos
Em 24 de abril de 2014, o IASB decidiu provisoriamente que a Estrutura Conceitual:

(a) deve manter a distinção binária existente de passivo e patrimônio líquido e construir sobre o feedback recebido sobre o documento de reflexão para desenvolver definições de passivo e patrimônio líquido; e

(b) não deve fornecer orientações detalhadas sobre como fazer a distinção entre passivos de instrumentos de capital.

O IASB irá continuar a discussão sobre este tema nesta reunião.
Em 24 de abril de 2014, o IASB provisoriamente decidiu construir sobre as propostas no documento de discussão, alterados em função das respostas recebidas, em vez de empreender novos trabalhos de investigação sobre a mensuração.

Em 23 de julho de 2014, o IASB discutiu o objetivo da mensuração e tentativamente decidiu que o Projeto de Exposição deve:

(a) não definir um objetivo de mensuração separado; e

(b) descrever como se segue como mensuração 
ativos e passivos pode não fornecer a informação mais relevante para os usuários das demonstrações financeiras.

(c) ao selecionar a mensuração a utilizar para um item específico, o IASB deve considerar qual informação essa mensuração irá produzir tanto na demonstração de posição financeira quanto na(s) demonstração(ões) de lucros ou perdas e OCI.

(d) a seleção de uma mensuração:

(i) para um ativo específico deve depender de como esse ativo contribui para futuros fluxos de caixa; e

(ii) para um passivo específico deve depender de como a entidade irá liquidar ou cumprir esse passivo.

(e) o número de mensurações diferentes usadas deve ser o menor número necessário para fornecer uma informação relevante. Mudanças desnecessárias de mensuração devem ser evitadas e as mudanças necessárias de mensuração devem ser explicadas.

(f) os benefícios de uma mensuração específica para os usuários das demonstrações financeiras precisam ser suficientes para justificar o seu custo. contribui para o objetivo global de relatórios financeiros:

"Mensuração é o processo de quantificar em termos de informação monetária sobre os recursos de uma entidade, as reivindicações contra a entidade $\mathrm{e}$ as mudanças nos recursos $\mathrm{e}$ reivindicações. Essa informação ajuda os usuários a avaliar as perspectivas de fluxos de caixa futuros da entidade e avaliar o desempenho da administração de recursos da entidade."

O IASB também discutiu as implicações das características qualitativas da informação financeira útil para mensuração e tentativamente decidiu que o Projeto de Exposição deve:

(a) afirmam que quando o IASB seleciona uma base de mensuração, deve considerar a natureza e relevância da informação resultante produzido tanto na demonstração da posição financeira quanto na declaração dos lucros ou prejuízos e outros resultados abrangentes (OCI).

(b) afirmam que:

(i) o nível de incerteza associada à mensuração de um item é um dos fatores que devem ser considerados ao selecionar uma base de mensuração; e,

(ii) se a mensuração está sujeita a um alto grau de incerteza de medição, esse fato, por si só, significa que a mensuração não fornece informações relevantes.

(c) não fazer uso explícito do termo 'confiabilidade' para descrever o nível de incerteza de mensuração associada à medição de um item.

(d) manter a discussão da representação fiel incluído no Documento de Discussão.

(e) discutir na seção de mensuração que uma representação fiel por si só, não resulta necessariamente em informação útil. As informações fornecidas pela representação devem também ser relevantes.

(f) explicar a necessidade de pesar os benefícios da introdução de uma base nova ou diferente de mensuração contra qualquer aumento de custos ou complexidade. Isso iria substituir a declaração no documento de discussão, que o número de bases de mensuração deve ser a menor necessário para oferecer informações relevantes.

(g) manter a discussão de mudanças necessárias e desnecessárias em bases de mensuração incluídas no documento de reflexão.

(h) manter a discussão de reforçar outras características qualitativas incluídas no Documento de Discussão.

(i) declarar explicitamente na seção de mensuração que a restrição de custo-benefício é um dos fatores que o IASB deve considerar ao selecionar uma mensuração.

Em 23 de julho de 2014, o IASB discutiu uma proposta de trabalho inicial da descrição e discussão das bases de mensuração para o Projeto de Exposição. O IASB instruiu a equipe a trazer 


\begin{tabular}{|c|c|}
\hline & $\begin{array}{l}\text { um documento para uma futura reunião que: } \\
\text { (a) grupos de bases de mensuração em um } \\
\text { pequeno número de categorias (por exemplo, } \\
\text { mensuração a custo histórico e corrente); e, } \\
\text { (b) reduzir o número de bases de medição descrito } \\
\text { (por exemplo, através da combinação de bases de } \\
\text { medição semelhantes e eliminando a descrição das } \\
\text { bases de mensuração pouco utilizadas). } \\
\text { Em } 24 \text { de julho de 2014, o IASB discutiu } \\
\text { mensuração com base em fluxo de caixa e decidiu } \\
\text { provisoriamente que a finalidade das técnicas de } \\
\text { mensuração com base em fluxo de caixa são } \\
\text { normalmente para implementar uma das bases de } \\
\text { mensuração que serão descritos na Estrutura } \\
\text { Conceitual. No entanto, se o IASB decidir em uma } \\
\text { Norma específica usar uma técnica de mensuração } \\
\text { com base em fluxo de caixa para implementar uma } \\
\text { base de mensuração que não é um dos descritos na } \\
\text { Estrutura Conceitual, a base para conclusões sobre } \\
\text { que Norma deve explicar o porquê. } \\
\text { O IASB também decidiu provisoriamente que o } \\
\text { projeto de exposição deve incluir orientações } \\
\text { sobre: } \\
\text { (a) as diferentes abordagens para lidar com fluxos } \\
\text { de caixa incertos; } \\
\text { (b) o uso de taxas de desconto. Esta orientação } \\
\text { poderia afirmar, entre outras coisas, que, se uma } \\
\text { entidade mensura um item usando uma técnica de } \\
\text { mensuração com base em fluxo de caixa, e o efeito } \\
\text { do valor do dinheiro no tempo é significativo para } \\
\text { os fluxos de caixa associados a esse item, então a } \\
\text { entidade deve descontar os fluxos de caixa para } \\
\text { refletir o valor do dinheiro no tempo; e, } \\
\text { (c) como decidir quando a mensuração de um } \\
\text { passivo deve incluir o efeito da qualidade de } \\
\text { crédito de uma entidade que relata. } \\
\text { O IASB irá continuar a discussão sobre } \\
\text { mensuração nesta reunião. }\end{array}$ \\
\hline \multicolumn{2}{|c|}{$\begin{array}{c}\text { Seção } 7 \\
\text { Apresentaçâo e Divulgação }\end{array}$} \\
\hline $\begin{array}{l}\text { Opiniões preliminares do IASB sobre a } \\
\text { apresentação e divulgação são de que: } \\
\text { (a) o objetivo das demonstrações financeiras } \\
\text { primárias é fornecer informações resumidas sobre } \\
\text { os ativos, passivos, patrimônio, receitas e } \\
\text { despesas, das mutações do patrimônio líquido e } \\
\text { fluxos de caixa, classificadas e agregadas em uma } \\
\text { forma que seja útil para os usuários das } \\
\text { demonstrações contábeis na tomada de decisões } \\
\text { sobre o fornecimento de recursos para a entidade. } \\
\text { (b) o objetivo das notas explicativas às } \\
\text { demonstrações financeiras é o de completar as } \\
\text { demonstrações financeiras, fornecendo } \\
\text { informaçôes adicionais úteis sobre: } \\
\text { (i) os ativos, passivos, patrimônio, receitas e } \\
\text { despesas, das mutações do patrimônio líquido e } \\
\text { fluxos de dinheiro da entidade; e, } \\
\text { (ii) com que eficácia a gestão da entidade } \\
\text { descarrega seus passivos no uso dos recursos da } \\
\text { entidade. }\end{array}$ & $\begin{array}{l}\text { Em } 19 \text { de junho de 2014, o IASB decidiu } \\
\text { provisoriamente: } \\
\text { (a) reconfirmar a proposta no documento de } \\
\text { discussão que cada Norma deve ter um objetivo } \\
\text { claro para os requisitos de divulgação e } \\
\text { apresentação; } \\
\text { (b) para reconfirmar a proposta no documento de } \\
\text { discussão que o IASB deve desenvolver requisitos } \\
\text { de divulgação e apresentação que promovem a } \\
\text { comunicação efetiva de informação financeira útil; } \\
\text { (c) incluir na Estrutura Conceitual esses princípios } \\
\text { de comunicação propostos no documento de } \\
\text { discussão, que são principalmente dirigidas ao } \\
\text { IASB e discutir como eles se relacionam com as } \\
\text { características qualitativas da informação } \\
\text { financeira útil. Especificamente, o IASB decidiu } \\
\text { provisoriamente que os requisitos de divulgação } \\
\text { devem procurar: } \\
\text { (i) promover a divulgação de informação útil que é } \\
\text { específica para a entidade; }\end{array}$ \\
\hline
\end{tabular}


(c) para cumprir o objetivo de divulgação, o IASB normalmente consideraria a exigência de divulgação sobre o seguinte:

(i) a entidade participante como um todo;

(ii) valores reconhecidos nas demonstrações financeiras primárias da entidade, incluindo alterações nesses valores (por exemplo, desagregação dos itens de linha, reconciliação);

(iii) a natureza e extensão dos ativos e passivos não reconhecidos da entidade;

(iv) a natureza e a extensão dos riscos decorrentes de ativos e passivos da entidade

(reconhecidos ou não reconhecidos); e,

(v) métodos, pressupostos e julgamentos, e as mudanças nesses métodos, suposições e julgamentos, que afetam os montantes apresentados ou de outra forma divulgados.

(d) o conceito de relevância é claramente descrito na Estrutura Conceitual existente.

Consequentemente, o IASB não propõe a alterar, ou acrescentar, à orientação da Estrutura Conceitual sobre relevância. No entanto, o IASB está considerando o desenvolvimento de orientações adicionais ou material educativo sobre a relevância fora do projeto de Estrutura Conceitual.

(e) informações prospectivas seriam incluídas nas notas explicativas às demonstrações financeiras se fornecem informações relevantes sobre ativos e passivos existentes, ou sobre os ativos e passivos que existiram durante o período de relatórios. (ii) resultar em divulgações que são claras, equilibradas e compreensíveis;

(iii) evitar a duplicação da mesma informação em diferentes partes das demonstrações financeiras; e, (iv) otimizar a comparabilidade sem comprometer a utilidade da informação divulgada; e

(d) a não incluir na Estrutura Conceitual uma discussão sobre as demonstrações financeiras em um formato eletrônico.

O IASB também decidiu provisoriamente que não iria alterar o conceito de materialidade no parágrafo QC11 da Estrutura Conceitual existente, exceto para esclarecer que o termo "usuários" citado no parágrafo, refere-se aos usuários primários mencionados no capítulo 1 da Estrutura Conceitual.

Em 24 de julho de 2014, o IASB discutiu o alcance e o conteúdo da orientação de apresentação e divulgação e tentativamente decidiu que o Projeto de Exposição deve:

(a) não introduzir a noção de "demonstrações financeiras primárias" que tinham sido propostas no Documento de Discussão;

(b) afirmar de que o objetivo das demonstrações financeiras é fornecer informações sobre ativos, passivos, patrimônio líquido, receitas e despesas da entidade, que são úteis para os usuários das demonstrações financeiras para avaliar as perspectivas de futuros fluxos de caixa líquidos para a entidade e na avaliação da gestão dos recursos da entidade. Como resultado, as demonstrações financeiras fornecem informações sobre a posição financeira, desempenho financeiro e fluxos de caixa de uma entidade;

(c) discutir as divulgações que o IASB, normalmente deve exigir no estabelecimento de Normas (mas não devem dar exemplos de diferentes tipos de divulgações);

(d) manter a discussão de divulgação de riscos e informações prospectivas proposto no Documento de Discussão. Em particular:

(i) o IASB normalmente considera exigir divulgações sobre a natureza e a extensão dos riscos decorrentes de ativos e passivos da entidade; e,

(ii) o IASB deve exigir que informações sobre o futuro sejam incluídas nas notas explicativas às demonstrações financeiras apenas se ele fornece informações relevantes sobre os ativos e passivos que existiam no final, ou durante, o período em análise;

(e) manter a orientação sobre a classificação e agregação, compensando e informações comparativas proposto no Documento de Discussão, em particular, que:

(i) a fim de apresentar a informação que é compreensível, uma entidade deve classificar, agregar e desagregar as informações sobre os elementos reconhecidos de uma forma que reflitam semelhanças nas propriedades da informação; 


\begin{tabular}{|c|c|}
\hline & $\begin{array}{l}\text { (ii) compensação de itens de natureza diferente } \\
\text { geralmente não fornecem as informações mais } \\
\text { úteis; e, } \\
\text { (iii) a informação comparativa é uma parte } \\
\text { integrante das demonstrações financeiras de uma } \\
\text { entidade para o período atual, pois fornece } \\
\text { informações sobre tendências relevantes. }\end{array}$ \\
\hline \multicolumn{2}{|c|}{$\begin{array}{c}\text { Seção 8 } \\
\text { Apresentação na Demonstração do Resultado Abrangente }\end{array}$} \\
\hline $\begin{array}{l}\text { A Seção } 8 \text { discute: } \\
\text { (a) o propósito da(s) declaração(ões) dos lucros ou } \\
\text { perdas e OCI, e } \\
\text { (b) se a Estrutura Conceitual deve exigir um total } \\
\text { de lucros ou perdas e se deve exigir ou permitir a } \\
\text { reciclagem. } \\
\text { As opiniões preliminares do IASB são: } \\
\text { (a) a Estrutura Conceitual deve exigir um total ou } \\
\text { subtotal de lucros ou perdas, que também resulte, } \\
\text { ou possa resultar, em alguns itens de receita ou } \\
\text { despesa a serem reciclados; e, } \\
\text { (b) o uso de OCI deve ser limitado a itens de } \\
\text { receitas ou despesas decorrentes de mudanças nas } \\
\text { mensuras atuais de ativos e passivos (novas } \\
\text { mensurações). No entanto, nem todas essas novas } \\
\text { mensurações seriam elegíveis para reconhecimento } \\
\text { em OCI. A Seção } 8 \text { descreve duas abordagens que } \\
\text { podem ser utilizadas para definir quais } \\
\text { remensurações podem ser incluídas no OCI. }\end{array}$ & $\begin{array}{l}\text { Em } 19 \text { de junho de 2014, o IASB decidiu } \\
\text { provisoriamente que a Estrutura Conceitual deve: } \\
\text { (a) exigir resultados (lucros ou perdas) como um } \\
\text { total ou subtotal. } \\
\text { (b) descrever os lucros ou prejuízos, como a } \\
\text { principal fonte de informações sobre o } \\
\text { desempenho de uma entidade para o período, mas } \\
\text { enfatizar que não é a única fonte de tais } \\
\text { informações. Por exemplo, os itens incluídos na } \\
\text { OCI também fornecem informações sobre o } \\
\text { desempenho de uma entidade. } \\
\text { (c) descrever o duplo objetivo de lucro ou prejuízo, } \\
\text { como descreve o retorno que a entidade tem feito } \\
\text { em seus recursos econômicos durante o período, e } \\
\text { fornecendo informações que são úteis para avaliar } \\
\text { as perspectivas de fluxos de caixa futuros. } \\
\text { (d) incluem um pressuposto refutável de que todos } \\
\text { os itens de receita e despesa devem ser incluídos } \\
\text { nos lucros ou prejuízos a menos que o IASB } \\
\text { concluiu em um determinado padrão que a } \\
\text { inclusão de um item de receita e despesa, ou um } \\
\text { componente de tal item em OCI reforçaria a } \\
\text { relevância do lucro ou prejuízo, como a principal } \\
\text { fonte de informações sobre o desempenho de uma } \\
\text { entidade para o período. } \\
\text { (e) afirmam que um exemplo, quando a presunção } \\
\text { refutável discutido em (d) acima pode ser ilidida é } \\
\text { quando o IASB concluiu que uma base de } \\
\text { mensuração é apropriada para um ativo ou um } \\
\text { passivo na demonstração da posição financeira e } \\
\text { outra base de mensuração é apropriado para lucro } \\
\text { ou prejuízo. Nesses casos, a diferença resultante } \\
\text { seria relatada em OCI. } \\
\text { (f) incluem um pressuposto refutável de que todos } \\
\text { os itens de receita e despesa incluída na OCI } \\
\text { devem ser reciclados para o resultado. } \\
\text { Em } 24 \text { de julho de } 2014 \text {, o IASB discutiu por que } \\
\text { o lucro ou perda é a principal fonte de informações } \\
\text { sobre o desempenho de uma entidade para o } \\
\text { período. O IASB decidiu provisoriamente que o } \\
\text { projeto de exposição deve: } \\
\text { (a) propor que a presunção para a inclusão de itens } \\
\text { de receita e despesa em lucro ou prejuízo não pode } \\
\text { ser ilidida por itens de receitas e despesas que } \\
\text { nos custos de ativos e passivos; } \\
\text { de passivos, e somente se, inclusive } \\
\text { argas - ou componentes dessas }\end{array}$ \\
\hline
\end{tabular}




\begin{tabular}{|c|c|}
\hline & $\begin{array}{l}\text { mudanças - em OCI aumenta a relevância dos } \\
\text { lucros ou prejuízos como a principal fonte de } \\
\text { informações sobre o desempenho de uma entidade } \\
\text { para o período; e, } \\
\text { (c) enfatizar que inclusive itens de receita e } \\
\text { despesa resultante de mudanças nas mensurações } \\
\text { atuais de ativos e passivos, ou componentes dessas } \\
\text { mudanças - em OCI é uma aplicação de } \\
\text { classificação, agregação e desagregação, princípio } \\
\text { para a apresentação e divulgação, que é projetado } \\
\text { para proporcionar uma comunicação eficaz de } \\
\text { informações financeiras e para tornar essas } \\
\text { informações mais compreensíveis. }\end{array}$ \\
\hline \multicolumn{2}{|c|}{$\begin{array}{c}\text { Seção 9 } \\
\text { Outras Questões } \\
\text { Canítulos 1 e } 3\end{array}$} \\
\hline & os 1 e 3 \\
\hline $\begin{array}{l}\text { A Seção } 9 \text { discute: } \\
\text { (a) a abordagem do IASB ao Capítulo } 1 \text {-“O } \\
\text { Objetivo de Uso Geral Relatórios Financeiros" e } \\
\text { Capítulo } 3 \text { - "As características qualitativas da } \\
\text { informação financeira útill" da Estrutura Conceitual } \\
\text { existente. O IASB não pretende, } \\
\text { fundamentalmente, repensar o conteúdo desses } \\
\text { capítulos. No entanto, o IASB irá fazer alterações } \\
\text { a esses capítulos se houver trabalho no resto das } \\
\text { áreas destacadas da Estrutura Conceitual dentro } \\
\text { desses capítulos que necessitem de clarificação ou } \\
\text { de alteração. A Seção } 9 \text { também discute as } \\
\text { preocupações que alguns têm levantado com a } \\
\text { forma como estes capítulos lidam com as questões } \\
\text { de administração, segurança e prudência. }\end{array}$ & $\begin{array}{l}\text { Administração } \\
\text { Em } 21 \text { de Maio de 2014, o IASB provisoriamente } \\
\text { decidiu alterar o Capítulo } 1 \text { da Estrutura } \\
\text { Conceitual para aumentar o destaque da } \\
\text { administração dentro do objetivo geral dos } \\
\text { Relatórios Financeiros. Ele faria isso, identificando } \\
\text { as informações necessárias para avaliar a eficácia } \\
\text { da gestão como não se sobrepõem totalmente com } \\
\text { as informações necessárias para ajudar os usuários } \\
\text { a avaliar as perspectivas de futuros fluxos de caixa } \\
\text { líquidos para a entidade. } \\
\text { Confiabilidade } \\
\text { Em } 21 \text { de Maio de 2014, o IASB decidiu } \\
\text { provisoriamente: } \\
\text { (a) não substituir a característica qualitativa da } \\
\text { representação fiel com a confiabilidade; } \\
\text { (b) de não incluir referência à confiabilidade tanto } \\
\text { como uma característica qualitativa adicional ou } \\
\text { um aspecto qualquer da relevância ou } \\
\text { representação fiel; e, } \\
\text { (c) considerar na elaboração se é possível dar } \\
\text { maior destaque à ideia expressa no parágrafo } \\
\text { QC16 da Estrutura Conceitual existente que, se o } \\
\text { nível de incerteza associada a uma estimativa for } \\
\text { suficientemente grande, essa estimativa não pode } \\
\text { fornecer informações relevantes. } \\
\text { Prudência } \\
\text { Em } 21 \text { de Maio de 2014, o IASB decidiu } \\
\text { provisoriamente: } \\
\text { (a) reintroduzir uma referência à prudência na } \\
\text { Estrutura Conceitual; } \\
\text { (b) descrever a prudência como o exercício de } \\
\text { cautela ao fazer juízos em condições de incerteza. } \\
\text { O exercício da prudência é consistente com a } \\
\text { neutralidade e não deve permitir que o exagero ou } \\
\text { subavaliação de ativos, passivos, receitas ou } \\
\text { despesas; e, } \\
\text { (c) discutir nas bases para conclusões à } \\
\text { importância da prudência para preparadores na } \\
\text { elaboração das demonstrações financeiras e do } \\
\text { IASB ao definir Normas. }\end{array}$ \\
\hline
\end{tabular}




\begin{tabular}{|c|c|}
\hline & $\begin{array}{l}\text { Outros aspectos dos capítulos } 1 \text { e } 3 \\
\text { Em } 21 \text { de Maio de 2014, o IASB discutiu os } \\
\text { capítulos } 1 \text { e } 3 \text { da Estrutura Conceitual e decidiu } \\
\text { provisoriamente: } \\
\text { (a) alterar o capítulo } 3 \text { características qualitativas } \\
\text { da informação financeira útil para explicar que a } \\
\text { forma legal de um item é diferente de sua } \\
\text { substância econômica subjacente, relatar esse item } \\
\text { de acordo com sua forma jurídica não resultaria } \\
\text { em uma representação fiel; } \\
\text { (b) não fazer nenhuma alteração para a descrição } \\
\text { do principal grupo de usuários identificados no } \\
\text { Capítulo } 1 \text { O Objetivo de dos Relatórios } \\
\text { Financeiros de Uso Geral; } \\
\text { (c) não elevar a característica qualitativa } \\
\text { compreensibilidade a uma característica qualitativa } \\
\text { fundamental; e, } \\
\text { (d) não adicionar uma discussão sobre a } \\
\text { complexidade da Estrutura Conceitual. }\end{array}$ \\
\hline \multicolumn{2}{|c|}{ Entidade que Relata } \\
\hline $\begin{array}{l}\text { O IASB não incluiu uma discussão sobre a } \\
\text { entidade que relata no presente Documento de } \\
\text { Discussão, porque o IASB emitiu já um } \\
\text { documento de discussão e um Projeto de } \\
\text { Exposição sobre este tema. O IASB pretende que o } \\
\text { projeto de exposição da Estrutura Conceitual irá } \\
\text { incluir material sobre a entidade que relata, com } \\
\text { base no Projeto de Exposição } 2010 \text { e atualizada à } \\
\text { luz dos comentários recebidos sobre o Projeto de } \\
\text { Exposição. }\end{array}$ & $\begin{array}{l}\text { Em } 21 \text { de Maio de 2014, o IASB decidiu } \\
\text { provisoriamente que: } \\
\text { (a) A entidade que relata é uma entidade que } \\
\text { escolhe, ou é necessário apresentar demonstrações } \\
\text { contábeis para fins gerais. } \\
\text { (b) Uma entidade que relata não precisa ser uma } \\
\text { pessoa jurídica, e poderia incluir uma entidade sem } \\
\text { personalidade jurídica, uma parte de uma entidade, } \\
\text { ou duas ou mais entidades. } \\
\text { (c) a Estrutura Conceitual não deve discutir } \\
\text { controle conjunto e influência significativa. } \\
\text { (d) Em geral, as demonstrações financeiras } \\
\text { consolidadas são mais propensas do que as } \\
\text { demonstrações financeiras não consolidadas a a } \\
\text { fornecer informações que possam ser úteis para } \\
\text { mais usuários. } \\
\text { (e) Quando uma entidade for requerida a } \\
\text { apresentar deranonstrações } \\
\text { consolidadas, esta entidade também pode escolher, } \\
\text { ou se necessário, apresentar também } \\
\text { demonstrações financeiras não consolidadas. Essas } \\
\text { demonstrações financeiras não consolidadas deve } \\
\text { divulgar como os usuários podem obter } \\
\text { demonstrações financeiras consolidadas. } \\
\text { (f) A Estrutura Conceitual não deve especificar } \\
\text { quais combinações de negócios podem constituir } \\
\text { uma entidade que relata que poderiam } \\
\text { legitimamente preparar demonstrações financeiras } \\
\text { combinadas. } \\
\text { Além disso, o IASB provisoriamente confirmou } \\
\text { que as demonstrações financeiras devem ser } \\
\text { preparadas a partir da perspectiva da entidade que } \\
\text { relata como um todo. }\end{array}$ \\
\hline \multicolumn{2}{|c|}{ Modelo de Negócios } \\
\hline $\begin{array}{l}\text { Seção } 9 \text { discute o uso do conceito de modelo de } \\
\text { negócio em Relatórios Financeiros. O presente } \\
\text { documento não define o conceito de modelo de } \\
\text { negócio. No entanto, o parecer preliminar da IASB } \\
\text { é que as demonstrações financeiras podem ser } \\
\text { mais relevantes se considerar como uma entidade }\end{array}$ & $\begin{array}{l}\text { Em } 24 \text { de julho de 2014, o IASB provisoriamente } \\
\text { decidiu que o Projeto de Exposição não deve } \\
\text { fornecer uma única descrição mais abrangente de } \\
\text { como a natureza das atividades comerciais de uma } \\
\text { entidade afetaria a normatização. Em vez disso, o } \\
\text { IASB deve descrever, para cada área afetada, }\end{array}$ \\
\hline
\end{tabular}




\begin{tabular}{|c|c|}
\hline $\begin{array}{l}\text { conduz suas atividades comerciais quando se } \\
\text { desenvolve Normas novas ou revistas. }\end{array}$ & $\begin{array}{l}\text { como a consideração das atividades comerciais de } \\
\text { uma entidade afetaria configuração padrão. O } \\
\text { IASB também indica que a natureza das atividades } \\
\text { comerciais de uma entidade é suscetível de afetar a } \\
\text { mensuração, a unidade de conta, a distinção entre } \\
\text { lucro ou prejuízo e OCI, e apresentação e } \\
\text { divulgação. É menos provável que afeta outras } \\
\text { áreas abrangidas pela Estrutura Conceitual. }\end{array}$ \\
\hline \multicolumn{2}{|c|}{ Unidade de Conta } \\
\hline $\begin{array}{l}\text { A visão preliminar da IASB é que a unidade de } \\
\text { conta, normalmente, deve ser decidida quando se } \\
\text { desenvolve ou revisa Normas particulares e que, } \\
\text { na escolha de uma unidade de conta, devem-se } \\
\text { considerar as características qualitativas da } \\
\text { informação útil. }\end{array}$ & $\begin{array}{l}\text { Em } 19 \text { de junho de 2014, o IASB decidiu } \\
\text { provisoriamente que: } \\
\text { (a) determinar a unidade de conta é uma decisão } \\
\text { em nível de Normas; } \\
\text { (b) a Estrutura Conceitual deve descrever possíveis } \\
\text { unidades de conta; e, } \\
\text { (c) a Estrutura Conceitual deve incluir uma lista de } \\
\text { fatores a serem considerados quando da } \\
\text { determinação da unidade de conta, mas não deve } \\
\text { classificar as prioridades dos fatores. }\end{array}$ \\
\hline \multicolumn{2}{|c|}{ Continuidade } \\
\hline $\begin{array}{l}\text { No Documento de Discussão do IASB identificou } \\
\text { três situações em que o pressuposto de } \\
\text { continuidade é relevante (quando mensurar ativos } \\
\text { e passivos, quando identificar passivos e ao fazer } \\
\text { divulgações sobre a entidade). }\end{array}$ & $\begin{array}{l}\text { Em } 21 \text { de Maio de 2014, o IASB decidiu } \\
\text { provisoriamente que: } \\
\text { (a) O pressuposto da continuidade deve ser tratado } \\
\text { como um pressuposto subjacente. A Estrutura } \\
\text { Conceitual revista deve incluir a descrição atual do } \\
\text { pressuposto de continuidade, exceto que a frase } \\
\text { "reduzir materialmente a escala das suas } \\
\text { operações" deve ser substituída por "negociação } \\
\text { de cessar". Esta formulação é utilizada na IAS } 1 \\
\text { Presentation of Financial Statements e IAS } 10 \\
\text { Events After the Reporting Period; } \\
\text { (b) O IASB não deve fornecer orientação adicional } \\
\text { na Estrutura Conceitual sobre o pressuposto da } \\
\text { continuidade; e } \\
\text { (c) O projeto não deve abordar: } \\
\text { (i) a preparação de demonstrações financeiras de } \\
\text { entidades que não estão em continuidade; e, } \\
\text { (ii) divulgações sobre continuidade. }\end{array}$ \\
\hline \multicolumn{2}{|c|}{ Manutenção de Capital } \\
\hline $\begin{array}{l}\text { O IASB poderá reconsiderar conceitos de } \\
\text { manutenção de capital se empreender um projeto } \\
\text { sobre a contabilização de inflação elevada. O } \\
\text { IASB pretende manter as descrições e discussão de } \\
\text { conceitos de manutenção de capital existentes na } \\
\text { Estrutura Conceitual revista praticamente } \\
\text { inalterado até que compromete um projeto como } \\
\text { este. }\end{array}$ & $\begin{array}{l}\text { Em } 24 \text { de abril de 2014, o IASB provisoriamente } \\
\text { decidiu deixar as descrições existentes e } \\
\text { discussões dos conceitos de manutenção de capital } \\
\text { na Estrutura Conceitual inalteradas, a menos que } \\
\text { os trabalhos na seção de mensuração do Projeto de } \\
\text { Exposição destacar a necessidade de se discutir } \\
\text { mais o assunto. }\end{array}$ \\
\hline \multicolumn{2}{|c|}{ Transição e data de vigência } \\
\hline $\begin{array}{l}\text { O resumo e o convite aos comentários do } \\
\text { Documento de Discussão afirmaram que uma vez } \\
\text { que o IASB finalizar a Estrutura Conceitual } \\
\text { revista, ele vai começar a usá-lo imediatamente. O } \\
\text { Documento de Discussão não forneceu qualquer } \\
\text { outra orientação sobre transição ou data de } \\
\text { vigência. }\end{array}$ & $\begin{array}{l}\text { Em } 24 \text { de julho de 2014, o IASB decidiu } \\
\text { provisoriamente que: } \\
\text { (a) IASB e do Comitê de Interpretações das IFRS } \\
\text { devem aplicar a Estrutura Conceitual revista } \\
\text { imediatamente após a sua publicação; } \\
\text { (b) devem dispor de um período de transição de } \\
\text { nada menos do que cerca de } 18 \text { meses para as } \\
\text { entidades que usam a Estrutura Conceitual } \\
\text { desenvolver e aplicar políticas contábeis para a } \\
\text { transação, outro acontecimento ou condição para a } \\
\text { qual IFRS não se aplica especificamente. A } \\
\text { aplicação antecipada deve ser permitida; e, }\end{array}$ \\
\hline
\end{tabular}




\begin{tabular}{|l|l|}
\hline & (c) nenhuma orientação adicional sobre a transição \\
deve ser fornecida na Estrutura Conceitual revista. \\
Consequentemente, as entidades seriam obrigados \\
a aplicar as disposições da IAS 8 Accounting \\
Policies, Changes in Accounting Estimates and \\
Errors para quaisquer alterações nas políticas \\
contábeis decorrentes de uma aplicação da \\
Estrutura Conceitual revista.
\end{tabular}

Fonte: Traduzido de IASB (2013) 


\section{APÊNDICES}




\section{APÊNDICE A - RELAÇÃO DE COMMENT LETTERS RECEBIDAS PELO IASB}

\begin{tabular}{|c|c|c|c|}
\hline & $\begin{array}{c}\text { Divulgação } \\
\text { Pública }\end{array}$ & Enviado por & Organização \\
\hline 1 & $01 / 08 / 2013$ & David Musoke & Sebira \& Company (Certified Public Accountants) \\
\hline 2 & $10 / 09 / 2014$ & Glenn Rechtschaffen & Individual \\
\hline 3 & $09 / 10 / 2013$ & Colin Haslam (Professor) & Queen Mary University of London \\
\hline 4 & $09 / 10 / 2013$ & Jorge José Gil & $\begin{array}{l}\text { Grupo Latinoamericano de Emisores de Normas de } \\
\text { Información Financiera (GLENIF) [Group of Latin-american } \\
\text { Accounting Standard Setters (GLASS)] }\end{array}$ \\
\hline 5 & $13 / 11 / 2013$ & peter wells & University of Technology Sydney \\
\hline 6 & $13 / 11 / 2013$ & Simon O'Neill & Australasian Council of Auditors-General \\
\hline 7 & $02 / 12 / 2013$ & Mark Ballamy & Ballamy LLP \\
\hline 8 & $02 / 12 / 2013$ & Venkatesh Srinivasan & Al Hosn Gas \\
\hline 9 & $02 / 12 / 2013$ & Peter Gibson & $\begin{array}{l}\text { The Heads of Treasuries Accounting and Reporting } \\
\text { Advis ory Committee (HoTARAC) }\end{array}$ \\
\hline 10 & $02 / 12 / 2013$ & Petri Vehmanen (Prof) & University of Tampere \\
\hline 11 & $09 / 12 / 2013$ & Ian Dennis & $\begin{array}{l}\text { Oxford Brookes University and the Norwegian School of } \\
\text { Economics (NHH) }\end{array}$ \\
\hline 12 & $09 / 12 / 2013$ & Andrey Brykin & Moscow Exchange \\
\hline 13 & $09 / 12 / 2013$ & Anna Davis & Landcorp Farming Limited \\
\hline 14 & $09 / 12 / 2013$ & Bjoern Schneider & The Linde Group \\
\hline 15 & $20 / 12 / 2013$ & Uwe Fies eler & IDW Institut der Wirtschafts prüfer \\
\hline 16 & $20 / 12 / 2013$ & Keith Reilly & Macquarie University \\
\hline 17 & $20 / 12 / 2013$ & Guochang Zhang & Hong Kong University of Science and Technology \\
\hline 18 & $20 / 12 / 2013$ & Clive Brodie & New Zealand Accounting Standards Board \\
\hline 19 & $20 / 12 / 2013$ & Agnes MATHIS & Cooperatives Europe \\
\hline 20 & $20 / 12 / 2013$ & Steven Maijoor & ESMA \\
\hline 21 & $20 / 12 / 2013$ & Boey Wong & The Hong Kong Association of Banks (HKAB) \\
\hline 22 & $20 / 12 / 2013$ & Rock Lefebvre & Certified General Accountants Association of Canada (CGA) \\
\hline 23 & $20 / 12 / 2013$ & Students & Indiana University \\
\hline 24 & $20 / 12 / 2013$ & Students & Indiana University \\
\hline 25 & $06 / 01 / 2014$ & Eduardo Pocetti & Ibracon \\
\hline 26 & $06 / 01 / 2014$ & Yew Kee Ho & National University of Singapore \\
\hline 27 & $06 / 01 / 2014$ & Tessa Park & Kingston Smith LLP \\
\hline 28 & $06 / 01 / 2014$ & Julie Dickson & $\begin{array}{l}\text { Office of the Superintendent of Financial Institutions } \\
\text { Canada (ASFI }\end{array}$ \\
\hline 29 & $06 / 01 / 2014$ & Mark Shying & CPA Australia Ltd \\
\hline 30 & $06 / 01 / 2014$ & Kelly Hicks & ICA Australia \\
\hline 31 & $06 / 01 / 2014$ & Takeshi Imamura & Individual \\
\hline 32 & $06 / 01 / 2014$ & Fernando Amaral & Ágora Incorporações \\
\hline 33 & $06 / 01 / 2014$ & Timothy Tam & The Hong Kong Association of Banks (HKAB) \\
\hline 34 & $06 / 01 / 2014$ & Kamalesh Gosalia & Certified General Accountants Association of Canada (CGA) \\
\hline 35 & $23 / 01 / 2014$ & Yasuyuki Fujii & The Japanese Society of Certified Pension Actuaries \\
\hline
\end{tabular}

\section{Continuação}




\begin{tabular}{|c|c|c|c|}
\hline 36 & 23/01/2014 & Bruce Donald & Financial Reporting Council (Australia) \\
\hline 37 & 23/01/2014 & Phil Hancock & University of Western Australia \\
\hline 38 & 23/01/2014 & Hans-Juergen Saeglitz & German Insurance Association (GDV) \\
\hline 39 & $23 / 01 / 2014$ & Claes Norberg & Confederation of Swedish Enterprise \\
\hline 40 & 23/01/2014 & Lise Croteau & Hydro-Québec \\
\hline 41 & $23 / 01 / 2014$ & James Halliwell & Syngenta \\
\hline 42 & 23/01/2014 & Andrew Higson & Loughborough University \\
\hline 43 & $23 / 01 / 2014$ & Benoît Pigé & University of Franche-Comté \\
\hline 44 & 23/01/2014 & Volker Heegemann & European Association of Cooperative Banks (EACB) \\
\hline 45 & $23 / 01 / 2014$ & Linda Mezon & Canadian Accounting Standards Board \\
\hline 46 & $23 / 01 / 2014$ & David Schraa & IIF \\
\hline 47 & $23 / 01 / 2014$ & Amy Hutchinson & ICAS \\
\hline 48 & $23 / 01 / 2014$ & Tom Quaadman & US Chamber of Commerce \\
\hline 49 & $23 / 01 / 2014$ & Andrey Bayrashev & Individual \\
\hline 50 & $23 / 01 / 2014$ & Romuald Bertl & AFRAC \\
\hline 51 & $23 / 01 / 2014$ & Edward Beale & City Group \\
\hline 52 & 23/01/2014 & David Oldroyd & $\begin{array}{l}\text { Financial Accounting and Reporting Special Interest Group } \\
\text { (FARSIG) of the British Accounting and Finance }\end{array}$ \\
\hline 53 & $23 / 01 / 2014$ & Adson Sousa & $\mathrm{OCB}$ \\
\hline 54 & $24 / 01 / 2014$ & Nigel Sleigh-Johns on (Dr) & $\begin{array}{l}\text { The Institute of Chartered Accountants in England and } \\
\text { Wales (ICAEW) }\end{array}$ \\
\hline 55 & 28/01/2014 & Michael Bradbury & Massey University \\
\hline 56 & $28 / 01 / 2014$ & Aina Liepins & International Ass sociation of Insurance Supervisors \\
\hline 57 & 29/01/2014 & Nels on Carvalho & Academic \\
\hline 58 & $29 / 01 / 2014$ & Charl Steyn & British American Tobacco \\
\hline 59 & 29/01/2014 & Gordon Heard & Financial Executives International Canada \\
\hline 60 & $29 / 01 / 2014$ & Russ Houlden & The 100 Group \\
\hline 61 & $30 / 01 / 2014$ & $\begin{array}{l}\text { JOSE CARLOS BEZERRA } \\
\text { DA SILVA }\end{array}$ & SECURITIES AND EXCHANGE COMMISSION OF BRAZIL \\
\hline 62 & $30 / 01 / 2014$ & JORGE LEAL & CONFECOOP \\
\hline 63 & $30 / 01 / 2014$ & Hayato Komada & The Life Insurance Association of Japan \\
\hline 64 & $30 / 01 / 2014$ & As ano Takenori & Keidanren \\
\hline 65 & $30 / 01 / 2014$ & Nicola Steele & Australian Institute of Company Directors \\
\hline 66 & $30 / 01 / 2014$ & Motohiro Koga & Japanese Bankers Association \\
\hline 67 & $30 / 01 / 2014$ & Sei-Ichi Kaneko & The Securities Analysts Association of Japan \\
\hline 68 & $30 / 01 / 2014$ & Hyun-Seon Hong & KASB \\
\hline 69 & $30 / 01 / 2014$ & Annette Selter & Federation of German Industries BDI \\
\hline 70 & $30 / 01 / 2014$ & Ralf Dr. Goebel & die Deutsche Kreditwirtschaft \\
\hline 71 & $30 / 01 / 2014$ & Liesel Knorr & ASCG \\
\hline 72 & $30 / 01 / 2014$ & Delwin Witthöft & Rio Tinto \\
\hline 73 & $30 / 01 / 2014$ & As Listed & Members of Japanese Companies \\
\hline 74 & $30 / 01 / 2014$ & Dov Sapir & Is rael Accounting Standards Board \\
\hline 75 & $30 / 01 / 2014$ & Yu Chen & China Accounting Standards Committee \\
\hline
\end{tabular}


Continuação

\begin{tabular}{|c|c|c|c|}
\hline 76 & $30 / 01 / 2014$ & Dieter Truxius & VMEBF e.V. \\
\hline 77 & $30 / 01 / 2014$ & Denis a Mularova & European Banking Federation \\
\hline 78 & $30 / 01 / 2014$ & Dieter Gahlen & DGRV e.V. \\
\hline 79 & $30 / 01 / 2014$ & Raj Juta & American International Corporation Inc \\
\hline 80 & $30 / 01 / 2014$ & Ros s ano Rimelli & Ancpl-Legacoop \\
\hline 81 & $30 / 01 / 2014$ & Charles Gould & International Co-operative Alliance \\
\hline 82 & $30 / 01 / 2014$ & Carlos Montalvo & EIOPA \\
\hline 83 & $30 / 01 / 2014$ & Jan Marton & University of Gothenburg \\
\hline 84 & $30 / 01 / 2014$ & Prof. Pedro & $\mathrm{CP}$ \\
\hline 85 & $30 / 01 / 2014$ & Volker Christ & Freudenberg \& Co. KG \\
\hline 86 & $30 / 01 / 2014$ & Naina Ralhan & Canadian Bankers Association \\
\hline 87 & $30 / 01 / 2014$ & Philipp Leu & SIX Exchange Regulation \\
\hline 88 & $30 / 01 / 2014$ & Richard Martin & ACCA \\
\hline 89 & $30 / 01 / 2014$ & Prof. Arnold Schilder & IAASB \\
\hline 90 & $30 / 01 / 2014$ & Colin Chau & \\
\hline 91 & $30 / 01 / 2014$ & Robert Dohrer & RSM International \\
\hline 92 & $30 / 01 / 2014$ & Peter Malmqvist & SFF (Sw Analyst Assoc) \\
\hline 93 & $30 / 01 / 2014$ & Andrew Buchanan & $\mathrm{BDO}$ \\
\hline 94 & $30 / 01 / 2014$ & Göran Arnell & FAR \\
\hline 95 & $30 / 01 / 2014$ & Linda Mezon & Canadian Accounting Standards Board \\
\hline 96 & $30 / 01 / 2014$ & Antonio Corbi & ISDA Inc. \\
\hline 97 & $30 / 01 / 2014$ & Steven Cain & CIPFA \\
\hline 98 & $30 / 01 / 2014$ & Charles McDonough & World Bank \\
\hline 99 & $30 / 01 / 2014$ & Bruno Roelants & $\begin{array}{l}\text { International Organization of Industrial, Artis anal and } \\
\text { Service Producers ' Cooperatives - CICOPA }\end{array}$ \\
\hline 100 & $30 / 01 / 2014$ & Richard Middleton & AFME \\
\hline 101 & $30 / 01 / 2014$ & Michael Crook & ICCIC \\
\hline 102 & $30 / 01 / 2014$ & Andrea Enria & EBA \\
\hline 103 & $30 / 01 / 2014$ & Emilio Linares-Rivas & Repsol \\
\hline 104 & $30 / 01 / 2014$ & NANCY SCHROEDER & $\begin{array}{l}\text { Financial Reporting Committee, Institute of Management } \\
\text { Accountants }\end{array}$ \\
\hline 105 & $30 / 01 / 2014$ & $\begin{array}{l}\text { RAMON VICENTE } \\
\text { NICASTRO }\end{array}$ & $\begin{array}{l}\text { FEDERACION ARGENTINA DE CONSEJOS } \\
\text { PROFESIONALES DE CIENCIAS ECONOMICAS }\end{array}$ \\
\hline 106 & $30 / 01 / 2014$ & Adrienna Huffman & University of Utah \\
\hline 107 & $30 / 01 / 2014$ & Marthinus Gerber & University of Pretoria \\
\hline 108 & $30 / 01 / 2014$ & Elizabeth Gordon & $\begin{array}{l}\text { International Association for Accounting Education and } \\
\text { Research }\end{array}$ \\
\hline 109 & $30 / 01 / 2014$ & Felipe Perez Cervantes & CINIF \\
\hline 110 & $30 / 01 / 2014$ & Michael Tovey & UBS \\
\hline 111 & $30 / 01 / 2014$ & Nicolaas Smith & Capital Maintenance in Units of Constant Purchasing Power \\
\hline 112 & $30 / 01 / 2014$ & Keiko KISHIGAMI & JICAP \\
\hline 113 & $30 / 01 / 2014$ & Paul Morshuis & Shell International BV \\
\hline 114 & $30 / 01 / 2014$ & Veronica Poole & Deloitte \\
\hline 115 & $30 / 01 / 2014$ & Mohammad Faiz Azmi & Malaysian Accounting Standards Board \\
\hline
\end{tabular}


Continuação

\begin{tabular}{|c|c|c|c|}
\hline 116 & $30 / 01 / 2014$ & Marcus Beszile & ANEFAC \\
\hline 117 & $30 / 01 / 2014$ & Michael Monahan & American Council of Life Insurers \\
\hline 118 & $30 / 01 / 2014$ & Martijn Bos & Eumedion \\
\hline 119 & $30 / 01 / 2014$ & Andrew Carpenter & Association of British Insurers \\
\hline 120 & $30 / 01 / 2014$ & Annette Selter & Federation of German Industries BDI \\
\hline 121 & $30 / 01 / 2014$ & Michael Gullette & American Bankers Association \\
\hline 122 & $30 / 01 / 2014$ & Lars Machenil & BNP PARIBAS \\
\hline 123 & $30 / 01 / 2014$ & Jesper Cramon & A.P. Moller - Maersk Group \\
\hline 124 & $30 / 01 / 2014$ & Victoria O'Leary & Ernst \& Young \\
\hline 125 & $30 / 01 / 2014$ & Jonathan Susin & International Energy Accounting Forum(IEAF) \\
\hline 126 & $30 / 01 / 2014$ & Claes Jaszon & $\begin{array}{l}\text { Rådet för finansiell rapportering [The Swedish Financial } \\
\text { Reporting Board] }\end{array}$ \\
\hline 127 & $30 / 01 / 2014$ & Guido Bichis ao & European Investment Bank (EIB) \\
\hline 128 & $30 / 01 / 2014$ & Flortence Mangin & Caisse des Dépôts [Deposits Fund] \\
\hline 129 & $30 / 01 / 2014$ & Ludovica Rizzotti & Cassa Depositi e Prestit \\
\hline 130 & $30 / 01 / 2014$ & Christian Krämer & KfW Bankengruppe \\
\hline 131 & $30 / 01 / 2014$ & Lyn Wood & Financial Reporting Council (FRC) [Australia] \\
\hline 132 & $30 / 01 / 2014$ & Richard Macve & London School of Economics (LSE) \\
\hline 133 & $30 / 01 / 2014$ & Carien van Maourik & Open University Business School \\
\hline 134 & $30 / 01 / 2014$ & J. Alex Milburn & Individual \\
\hline 135 & $30 / 01 / 2014$ & Philip Holmes & Co-operatives UK \\
\hline 136 & $30 / 01 / 2014$ & Hoh Kim Hyan (Ms) & $\begin{array}{l}\text { Institut Akauntan Awam Bertauliah Malaysia [The } \\
\text { Malaysian Institute of Certified Public Accountants (CPA)] }\end{array}$ \\
\hline 137 & $30 / 01 / 2014$ & Pranav H. Variava & Securities and Exchange Board of India (SEBI) \\
\hline 138 & $30 / 01 / 2014$ & Sue Ludolph & South African Institute of Chartered Accountants (SAICA) \\
\hline 139 & $30 / 01 / 2014$ & Catherine Vandenborre & Elia System Operator \\
\hline 140 & $30 / 01 / 2014$ & Jean-Luc Vanderbroek & Fluxys Belgium \\
\hline 141 & $30 / 01 / 2014$ & David Termont & Eandis \\
\hline 142 & $30 / 01 / 2014$ & Dominique Offergeld & Ores SCRL \\
\hline 143 & $30 / 01 / 2014$ & Evgenia Koposova & NP Institute of Professional Accountants of Russia (IPAR) \\
\hline 144 & $30 / 01 / 2014$ & Guy R Judd & Standard Life Investments \\
\hline 145 & $30 / 01 / 2014$ & Roger Marshall & Financial Reporting Council (FRC) [UK] \\
\hline 146 & $30 / 01 / 2014$ & Fayezuk Choudhury & International Federation of Accountants (IFAC) \\
\hline 147 & $30 / 01 / 2014$ & Colin Burns & Baker Tilly Tax \& Accounting Limited \\
\hline 148 & $30 / 01 / 2014$ & Peter Walton & European Accounting Association (EAA) \\
\hline 149 & $30 / 01 / 2014$ & Aldo Soldi & Coopfond SpA \\
\hline 150 & $30 / 01 / 2014$ & José Hernán & Cicopa Mercosur \\
\hline 151 & $30 / 01 / 2014$ & $\begin{array}{l}\text { BARBET MASSIN } \\
\text { MALI }\end{array}$ & MAZARS \\
\hline 152 & $30 / 01 / 2014$ & Tim Ward & Quoted Companies Alliance \\
\hline 153 & $30 / 01 / 2014$ & Suat Cheng Goh & Singapore Accounting Standards Council \\
\hline 154 & $30 / 01 / 2014$ & Gregg Nelson & International Business Machines (IBM) \\
\hline 155 & $30 / 01 / 2014$ & Jorge Andrade Costa & Banco Bradesco \\
\hline
\end{tabular}


Continuação

\begin{tabular}{|c|c|c|c|}
\hline 156 & $30 / 01 / 2014$ & Glyn Parry & BT Group plc \\
\hline 157 & $30 / 01 / 2014$ & Hazel Corcoran & Canadian Worker Co-op Federation \\
\hline 158 & $30 / 01 / 2014$ & Yuzo Nagato & Japan Workers Co-operative Union \\
\hline 159 & $30 / 01 / 2014$ & Giovanni Costa & Braília's University \\
\hline 160 & $30 / 01 / 2014$ & Claudia Sanchez Bajo & University of Winnipeg \\
\hline 161 & $30 / 01 / 2014$ & Dianne Azoor Hughes & Pitcher Partners \\
\hline 162 & $30 / 01 / 2014$ & Gius eppe Guerini & federsolidariet Confcooperative \\
\hline 163 & $30 / 01 / 2014$ & Ana Martínez-Pina & $\begin{array}{l}\text { Instituto de Contabilidad y Auditoría de Cuentas (ICAC) } \\
\text { [Accounting and Auditing Institute of Spain] }\end{array}$ \\
\hline 164 & $30 / 01 / 2014$ & Paloma Arroyo & COCETA \\
\hline 165 & $30 / 01 / 2014$ & Gurpreet Manku & $\begin{array}{l}\text { BVCA - The British Private Equity \& Venture Capital } \\
\text { Association }\end{array}$ \\
\hline 166 & $30 / 01 / 2014$ & Massimo Costa & Individual \\
\hline 167 & $30 / 01 / 2014$ & Vaishali P. Koparkar & Larsen \& Toubro Ltd \\
\hline 168 & $30 / 01 / 2014$ & Maggie McGhee & National Audit Office \\
\hline 169 & $30 / 01 / 2014$ & Avinash Chander & The Institute of Chartered Accountants of India (ICAI) \\
\hline 170 & $30 / 01 / 2014$ & Kerrie Waring & International Corporate Governance Network (ICGN) \\
\hline 171 & $30 / 01 / 2014$ & Vincenzo Mannino & Confcooperative \\
\hline 172 & $30 / 01 / 2014$ & Adriano Tomo & Federacao Brasileira de Bancos (FEBRABAN) \\
\hline 173 & $30 / 01 / 2014$ & Kenneth C. Sharp & Grant Thornton International Ltd \\
\hline 174 & $30 / 01 / 2014$ & Jeff van Rooyen & $\begin{array}{l}\text { Financial Reporting Standards Council (FRSC) [the South } \\
\text { African Standard-setting body] }\end{array}$ \\
\hline 175 & $30 / 01 / 2014$ & Mark Vaessen & KPMG IFRG Limited \\
\hline 176 & $30 / 01 / 2014$ & Mohammad Abbas & Individual \\
\hline 177 & $30 / 01 / 2014$ & Stig Enevoldsen & The Danish Accounting Standards Committee (DASC) \\
\hline 178 & $30 / 01 / 2014$ & Márcio Lopes de Freitas & Organis atin of Brazilian Cooperatives (OCB) \\
\hline 179 & $30 / 01 / 2014$ & R A Collinge & UK Shareholders Association - 4 sections \\
\hline 180 & $30 / 01 / 2014$ & Modest Hamalabbi & Zambia Institute of Chartered Accountants (ZICA) \\
\hline 181 & $30 / 01 / 2014$ & Massimo Stronati & Federlavoro e Servizi Confcooperative \\
\hline 182 & $30 / 01 / 2014$ & Askold Birin & NOFA Foundation \\
\hline 183 & $30 / 01 / 2014$ & Richard F. McMahon,Jr & Edis on Electric Institute \\
\hline 184 & $30 / 01 / 2014$ & William R. Ford & American Gas Association \\
\hline 185 & $30 / 01 / 2014$ & David P. Smeltzer & National Association of Water Companies \\
\hline 186 & $30 / 01 / 2014$ & Owais Mukati & Institute of Chartered Accountants of Pakistan \\
\hline 187 & $30 / 01 / 2014$ & Hans de Munnik & $\begin{array}{l}\text { Raad voor de Jaarvers laggeving [Dutch Accounting } \\
\text { Standards Board (DASB)] }\end{array}$ \\
\hline 188 & $30 / 01 / 2014$ & Aleem Islan & The Association of Accounting Technicians (AAT) \\
\hline 189 & $30 / 01 / 2014$ & John Hitchins & PricewaterhouseCoopers LLP (PwC) [UK] \\
\hline 190 & $30 / 01 / 2014$ & & $\begin{array}{l}\text { Grupo Latinoamericano de Emisores de Normas de } \\
\text { Información Financiera (GLENIF) [Group of Latin-american } \\
\text { Accounting Standard Setters (GLASS)] }\end{array}$ \\
\hline 191 & $30 / 01 / 2014$ & Jean-Paul Caudal & $\begin{array}{l}\text { Fédération Bancaire Francaise (FBF) [French Banking } \\
\text { Federation] }\end{array}$ \\
\hline 192 & $30 / 01 / 2014$ & Dario Farcy & Confederación Nacional de Cooperativas de Trabajo (CNCT) \\
\hline 193 & $30 / 01 / 2014$ & Mike Page & University of Ports mouth \\
\hline 194 & $30 / 01 / 2014$ & C N Westworth & Westworth Kemp Consultants \\
\hline 195 & $30 / 01 / 2014$ & Karin Dohm & Deutsche Bank AG \\
\hline
\end{tabular}


Continuação

\begin{tabular}{|c|c|c|c|}
\hline 196 & $30 / 01 / 2014$ & Liz Murrall & Investment Management Association (IMA) \\
\hline 197 & $30 / 01 / 2014$ & Marcos Menezes & Petróleo Brasiliero SA - Petrobras \\
\hline 198 & $30 / 01 / 2014$ & Veronique Mathaud & Institute of International Finance (IIF) \\
\hline 199 & $30 / 01 / 2014$ & Daiva Zumbakiene & UAB Raimda auditas \\
\hline 200 & $30 / 01 / 2014$ & Michel Demaré & $\begin{array}{l}\text { Swis s Holdings [Federation of Industrial and Service Groups } \\
\text { in Switzerland] }\end{array}$ \\
\hline 201 & $30 / 01 / 2014$ & Federico Diomeda & $\begin{array}{l}\text { European Federation of Accountants and Auditors for } \\
\text { SMEs (EFAA) }\end{array}$ \\
\hline 202 & $30 / 01 / 2014$ & Joanna Dadacz & $\begin{array}{l}\text { Komitet Standardów Rachunkowości [Polish Accounting } \\
\text { Standards Committee] }\end{array}$ \\
\hline 203 & $30 / 01 / 2014$ & Salme Näsi & The Finnish Cooperative Concil \\
\hline 204 & $30 / 01 / 2014$ & Idésio Coelho & $\begin{array}{l}\text { Comitê de Pronunciamentos Contábeis (CPC) [Brazilian } \\
\text { Committee for Accounting Pronouncements ] }\end{array}$ \\
\hline 205 & $30 / 01 / 2014$ & Neville Mitchell & Group of 100 Inc. [Australia] \\
\hline 206 & $30 / 01 / 2014$ & Robert L. Brown & $\begin{array}{l}\text { Association Actuarielle Internationale (AAI) [nternational } \\
\text { Actuarial Association (IAA)] }\end{array}$ \\
\hline 207 & $30 / 01 / 2014$ & Siam Keong Chua & Individual \\
\hline 208 & $30 / 01 / 2014$ & Erlend Kvaal & $\begin{array}{l}\text { Norsk Regnskaps Stiftelse (NASB) [Norwegian Accounting } \\
\text { Standards Board] }\end{array}$ \\
\hline 209 & $30 / 01 / 2014$ & Susanne Kanngiesser (Dr) & Allianz \\
\hline 210 & $30 / 01 / 2014$ & Rene van Wyk & Basel Committee on Banking Supervision \\
\hline 211 & $30 / 01 / 2014$ & Patrice Marteau & $\begin{array}{l}\text { Association pour la participation des entreprises françaises } \\
\text { à l'harmonis ation comptable internationale (ACTEO) [French } \\
\text { association for the participation of businesses in the } \\
\text { convergence of accounting standards] }\end{array}$ \\
\hline 212 & $30 / 01 / 2014$ & François Soulmagnon & $\begin{array}{l}\text { Association française des entreprises privées (AFEP) } \\
\text { [French Association of private companies] }\end{array}$ \\
\hline 213 & $30 / 01 / 2014$ & Angès Lepinay & Mouvement des Entreprises de France (MEDEF) \\
\hline 214 & $30 / 01 / 2014$ & Rebecca Kemble & US Federation of Worker Cooperatives \\
\hline 215 & $30 / 01 / 2014$ & Ikuo Nis hikawa & Accounting Standards Board of Japan (ASBJ) \\
\hline 216 & $30 / 01 / 2014$ & Richard C. Jones & Hofs tra University \\
\hline 217 & $30 / 01 / 2014$ & Alphonse Kugeler & $\begin{array}{l}\text { Commission des normes comptables de Luxembourg } \\
\text { [Accounting Standards Commission of Luxembourg] }\end{array}$ \\
\hline 218 & $30 / 01 / 2014$ & Ikuo Nishikawa & Asian-Oceanian Standard-Setters Group (AOSSG) \\
\hline 219 & $30 / 01 / 2014$ & Jérôme P. Chauvin & Busines surope \\
\hline 220 & $30 / 01 / 2014$ & Leo van der Tas & Ernst \& Young Global Limited \\
\hline 221 & $30 / 01 / 2014$ & Hilde Blomme & $\begin{array}{l}\text { Fédération des Experts Comptables Européens (FEE) [The } \\
\text { Federation of European Accountants] }\end{array}$ \\
\hline 222 & $30 / 01 / 2014$ & Sharon Bowles & $\begin{array}{l}\text { Coordinators of the Economic \& Monetary Affairs' } \\
\text { Committee of the EP }\end{array}$ \\
\hline 223 & $30 / 01 / 2014$ & Olav Jones & European Insurance CFO Forum \\
\hline 224 & $30 / 01 / 2014$ & Jane Fuller & CFA Society of the UK \\
\hline 225 & $30 / 01 / 2014$ & Michimas a Satoh & Aichigakuin University \\
\hline 226 & $31 / 01 / 2014$ & Nigel Sleigh-Johns on & $\begin{array}{l}\text { The Institute of Chartered Accountants in England and } \\
\text { Wales (ICAEW) }\end{array}$ \\
\hline 227 & $31 / 01 / 2014$ & Sally Scutt & International Banking Federation (IBfed) \\
\hline
\end{tabular}

